$\boxplus$ UnB

\title{
Brasília, cinema e modernidade: percorrendo a cidade modernista
}

\author{
Liz da Costa Sandoval
}




\title{
$\Psi$ Universidade de Brasília
}

FACULDADE DE ARQUITETURA E URBANISMO

PROGRAMA DE PÓS-GRADUAÇÃO

TEORIA, HISTÓRIA E CRÍTICA

\section{Brasília, cinema e modernidade:}

Percorrendo a cidade modernista

\begin{abstract}
Arquiteta Liz da Costa Sandoval
Dissertação apresentada ao Programa de Pós-Graduação em Arquitetura e Urbanismo, da Faculdade de Arquitetura e Urbanismo da Universidade de Brasília, como parte dos requisitos para obtenção do título de Mestre. Linha de Pesquisa: Teoria, História e Crítica.

Orientadora: Professora Doutora Luciana Saboia Fonseca Cruz
\end{abstract}

Brasília, outubro de 2014 
Ficha catalográfica elaborada pela Biblioteca Central da Universidade de Brasília. Acervo 1017699.

S218b Sandoval, Liz da Costa.

Brasília, cinema e modernidade : percorrendo a cidade modernista / Liz da Costa Sandoval. - 2014.

$141 \mathrm{f}$. : il. ; $30 \mathrm{~cm}$.

Dissertação (mestrado) - Universidade de Brasília, Faculdade de Arquitetura e Urbanismo, Programa de Pós-Graduação em Arquitetura e Urbanismo, 2014. Inclui bibliografia.

Or ientação: Luciana Saboia Fonseca Cruz .

1. Urbanização - Brasília (DF). 2. Representação cinematográfica - Brasília (DF). 3. Cinema.

4. Brasília (DF) - Arquitetura moderna. I.Cruz, Luciana Sabóia Fonseca. II. Título. 


\section{$\Psi$ Universidade de Brasília}

FACULDADE DE ARQUITETURA E URBANISMO

PROGRAMA DE PÓS-GRADUAÇÃO

TEORIA, HISTÓRIA E CRÍTICA

\section{Brasília, cinema e modernidade:}

Percorrendo a cidade modernista

BANCA EXAMINADORA

Orientadora

Professora Doutora Luciana Saboia Fonseca Cruz

Membros

Professora Doutora Tania Siqueira Montoro

Professor Doutor Ricardo Trevisan

Professor Doutor Reinaldo Guedes Machado

Brasília, outubro de 2014 



\section{RESUMO}

Brasília, inaugurada em 1960, expressa o ideário modernista da Carta de Atenas pela setorização de sua concepção urbanística e a liberação do solo urbano para a livre circulação de veículos e pedestres. Brasília representou o anseio de modernidade do país, atraindo migrantes de todas as regiões, tornando-se polo de desenvolvimento no interior do Brasil. Os princípios da concepção urbana da capital que confere fluxos e movimentos peculiares à cidade não ficaram alheios às lentes cinematográficas.

É recorrente nos filmes brasilienses a utilização de cenas do movimento dos percursos de automóvel pela cidade. Numa perspectiva do carro em movimento, Brasília parece incorporar a velocidade do automóvel em sua vivência, e a leitura da sua paisagem que se dá em velocidade cria forte identificação com a imagem em movimento do cinema. Documentada por cinegrafistas desde a sua construção, Brasília mostra sua transformação nos filmes, que testemunham o dilaceramento da narrativa programática modernista, que se multiplica em narrativas de caráter transitório que valorizam o indivíduo ou as vivências de pequenos grupos sociais.

Estabelecendo uma narrativa a partir de alguns filmes de Brasília, que trazem a representação do espaço da cidade, seria possível perceber que o espaço apropriado, não como permanência, mas como experiência de fluidez, pode participar da construção de um imaginário coletivo referente aos percursos na cidade, produzindo formas de experiência do lugar? Ao confrontar o universo cinematográfico brasiliense e o circular, observa-se a cidade pelos caminhos que se percorrem cotidianamente e que fazem parte de uma construção através do tempo. $\mathrm{O}$ estudo percorre a modernidade, a cidade e o cinema, que irão embasar e complementar a análise das representações de Brasília.

Palavras-chave: Brasília, modernidade, urbanismo moderno, cinema. 


\section{ABSTRACT}

Brasilia, inaugurated in 1960, expresses the modernist ideals of the Charter of Athens in the compartmentalization of its urban design and the liberation of its urban ground for the free transit of vehicles and pedestrians. Brasília represented the yearning for modernity in the country, attracting migrants from all regions, and became a focal point of urban development in the interior of Brazil. The principles of urban design that give the capital its peculiar flows and movements did not go unnoticed to cinematographic lenses.

Movies about Brasilia often portray the routes followed by cars in the city. From the perspective of the moving car, Brasilia seems to embody the speed of the car in our experience of the city, and the reading of the landscape that occurs at speed creates a strong identification with the motion picture film. Documented by filmmakers since its construction, Brasilia has shown its transformation in movies that witness the destruction of the modernist programmatic narrative, thus multiplied in narratives of transitional character which value the experiences of individual or small social groups.

The narrative created by the movies about Brasilia that bring up the representation of the city's space begs the question: would it be possible for us to acknowledge that space, appropriated not as permanence but as fluidity, and participate in the construction of a collective imagination that relates to routes within the city, creating different experiences of place? By putting together the cinematographic universe of Brasilia and circulation, we can see the city through the paths that are frequently trodden and are part of a creation in time. This study follows modernity, the city, and cinema, which will be the foundations for an analysis of the representations of Brasilia.

Keywords: Brasilia, modernity, modern urbanism, cinema. 


\section{SUMÁRIO}

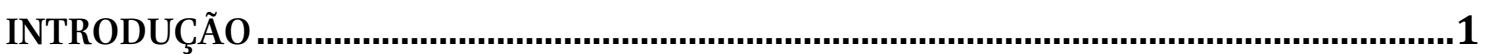

1. MODERNIDADE, CIDADE E CINEMA .................................................................. 7

1.1 Experiências da modernidade e o sentido de lugar: angústia e desejo de transformação.................... 8

1.2 Vanguardas artísticas: representações do efêmero ...................................................................11

1.3 O Movimento Moderno: ideário da máquina e a materialização do transitório...............................21

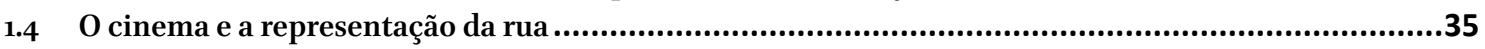

\section{MODERNIZAÇÃO E URBANIZAÇÃO NO BRASIL: CONEXÕES ENTRE A}

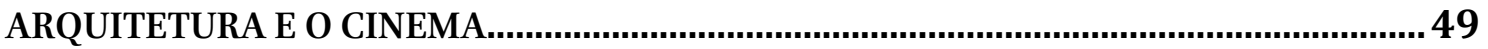

2.1 A Semana de 22: busca por modernidade ........................................................................50

2.2 Movimentos concretistas: geometria e corporeidade .........................................................56

2.3 Arquitetura moderna brasileira: a experiência vanguardista e a construção da identidade nacional ..61

2.4 A cidade brasileira, o cinema e o quadro de conflitos ideológicos................................................66

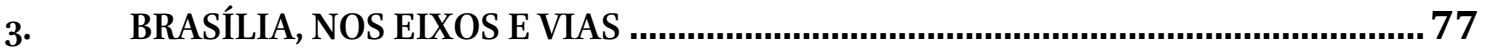

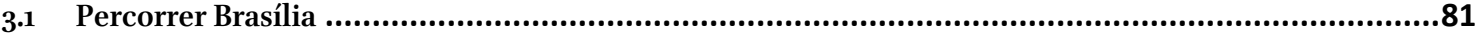

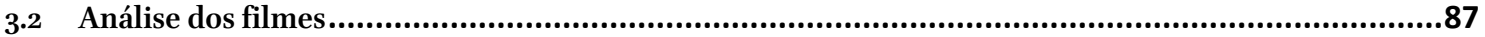

3.2.1 Do mito à realidade: "Contradições de uma cidade nova" ...................................................93

3.2.2 Censura e metáfora: "Bravos guerreiros" ....................................................................... 99

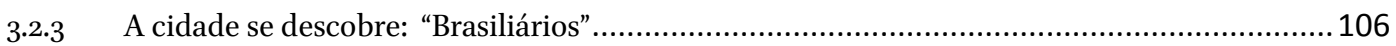

3.2.4 Crise de identidade: "A terceira margem do rio" .............................................................. 113

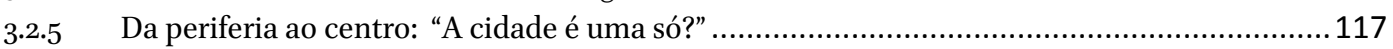

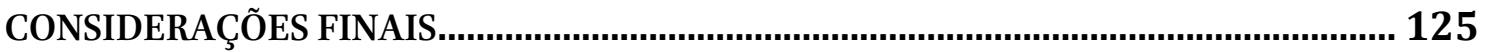

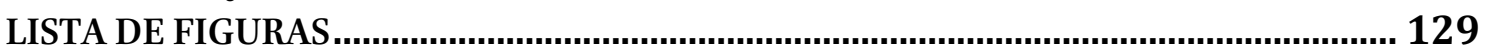

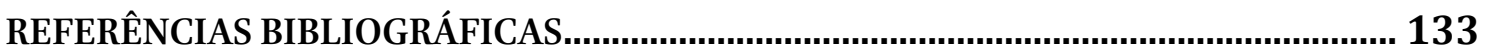

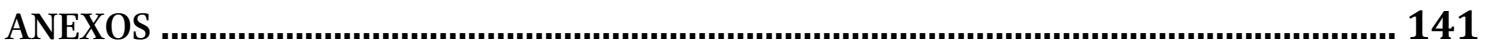





\section{INSTRUÇÕES PARA O DVD}

Esta pesquisa acompanha um DVD com alguns trechos de filmes citados durante o texto. $\mathrm{O}$ sinal $>$ ao lado do título do filme é acompanhado do número da faixa correspondente no DVD, e segue a seguinte ordem:

1. Brasília, planejamento urbano - Fernando Cony Campos, 1964

$>_{2}$. Brasília, contradições de uma cidade nova - Joaquim Pedro de Andrade, 1967

3. A chegada do trem à Estação Ciotat - Irmãos Lumière, 1896

$>_{4}$. Ballet mécanique - Fernand Léger, 1924

5. São Paulo, a symphonia da metrópole - de Adalberto Kemeny e Rodolpho Rex Lustig, 1929,

6. As primeiras imagens de Brasília - Jean Manzon, 1956

7. Fala, Brasília - Nelson Pereira dos Santos, 1966

8. Vestibular 70 - Vladimir Carvalho, 1970

9. UnB: Primeira experiência em pré-moldado - Heinz Forthman, 1970

10. Brasília ano 10 - Geraldo Sobral Rocha, 1970

11. Subterrâneos - José Eduardo Belmonte, 2003

12. Mínima Cidade - João Lanari, 1986

13. Brasiliários - de Zuleica Porto e Sérgio Bazi, 1986

14. Brasília, um dia em fevereiro - Maria Augusta Ramos, 1996

$>_{15}$. A concepção - José Eduardo Belmonte, 2005

16. A cidade é uma só? - Adirley Queirós, 2011 



\section{INTRODUÇÃO}

Na velocidade de um automóvel, como na visão de seu motorista, a câmera percorre uma passagem escura que se ilumina em direção à saída; percebe-se o céu, a via e uma plataforma horizontal, superior. A câmera agora aponta de cima para a mesma área: o cruzamento dos dois eixos que se cruzam no centro de Brasília - a rodoviária - e acompanha o automóvel que se afasta pelo eixo residencial. A câmera passa novamente para o interior do veículo, que, percorrendo o mesmo eixo, agora aponta para os edifícios residenciais. Esta é a cena inicial de Brasília: contradições de uma cidade nova (1967, Joaquim Pedro de Andrade).

Cenas do movimento dos percursos de automóvel pela cidade são recorrentes nos filmes brasilienses. Na vivência cotidiana, os deslocamentos em automóvel pelos eixos retilíneos enquadram paisagens de edificações que se repetem em ritmo contínuo, criando uma forte identificação com a imagem em movimento do cinema. Assim, Brasília parece incorporar a velocidade do automóvel em sua vivência. Os espaços planejados e a rede de circulação hierárquica de sua concepção urbanística modernista compõem uma imagem da cidade ligada aos fluxos da circulação, do movimento e da velocidade, e resultam numa maneira peculiar de percorrer Brasília.

A circulação criada por Lucio Costa com "o propósito de aplicar princípios da técnica rodoviária à técnica urbanística” (COSTA, 1995, p. 284) tornou-se característica da inovação que Brasília representou por consolidar alguns preceitos de circulação propostos na Carta de Atenas. Por representar uma novidade com relação à malha urbana tradicional, alguns filmes da década de 1960 preocupam-se em explicá-la, como é o caso de Brasília: Planejamento Urbano ${ }^{{ }_{1}}$ (1964, Fernando Cony Campos) e Brasília, contradições de uma cidade nova ${ }^{\not 2}(1967$, Joaquim Pedro de Andrade), no qual a cidade é percorrida enquanto se ouve a seguinte narração:

Deste modo, e com a introdução de trevos completos e passagens de níveis, o tráfego de automóveis e de ônibus se processa tanto na parte central como nos setores residenciais sem qualquer cruzamento. Fixada a rede geral do tráfego, estabeleceram-se tramas autônomas para o trânsito local dos pedestres garantindolhes o uso livre do chão ${ }^{1}$.

${ }^{1}$ Trecho de narração de "Brasília, contradições de uma cidade nova”, Joaquim Pedro de Andrade, 1967 . 
Seu plano urbanístico resulta das premissas do urbanismo moderno, que procurava incorporar os avanços tecnológicos e absorver as novas experiências de tempo e espaço produzidas pela máquina e pela velocidade, através da promoção de espaços concebidos racionalmente, que englobassem as principais funções da cidade moderna. Essas questões, trazidas pela modernidade, surgiram em decorrência do crescimento das cidades, da circulação e das tecnologias da indústria e da comunicação, que possibilitaram novas experiências espaciais e corporais. Esse ambiente de multiplicidade e liberdade também incentivou a criação do cinema.

Ao propor grandes vias de circulação com o intuito de modernizar as cidades, eliminando as estreitas e labirínticas ruas tradicionais, o urbanismo moderno é frequentemente acusado de "reduzir assim as possibilidades da experiência corporal direta, através do andar pelas ruelas e indiretamente, as experiências da alteridade urbana", como relata JACQUES (2012, p. 32). Mas a autora, em "Elogio aos errantes", afirma a sobrevivência dessas experiências, "contrapondo-se a todos os discursos que demonstram emprobecimento, perda, destruição ou, até mesmo, expropriação da experiência na cidade contemporânea" (idem, p.11).

Ao fazer isso, Jacques analisa as experiências urbanas realizadas por alguns errantes, em suas narrativas urbanas, compartilhadas - por textos, imagens, filmes - e que se afirmam como possibilidade de crítica, pela postura propositiva que realizam com relação à apreensão e compreensão da cidade, e por constituir uma forma de resistência aos métodos tradicionais da disciplina urbanística.

O errante, então, é aquele que busca um estado de corpo errante, que experimenta a cidade através das errâncias, que se preocupa mais com as práticas, ações e percursos, do que com as representações, planificações, projeções. O errante não vê a cidade somente de cima, a partir da visão de um mapa, mas a experimenta de dentro; ele inventa sua própria cartografia a partir de sua experiência itinerante. (JACQUES, 2012, p. 24)

A documentação da construção, inauguração e fatos importantes desta nova cidade pelas lentes dos anônimos, dos fotógrafos, jornalistas e cineastas, que chegaram junto com a sua construção, acabou estabelecendo uma forte relação entre a nova cidade e o cinema. E também formando um conjunto de registros de narrativas urbanas. Registros cinematográficos, principalmente os vinculados ao movimento do Cinema Novo ${ }^{2}$, como Glauber Rocha, Nelson Pereira dos Santos e Cacá

${ }^{2} \mathrm{O}$ Cinema Novo pode ser considerado um projeto político de uma cultura audiovisual crítica e conscientizadora, questionadora do mito da técnica e da burocracia de produção, desenhado por um grupo de cineastas e intelectuais. O imaginário do cinema novo foi engendrado, sobretudo nos últimos anos da década de 1950, na Bahia, 
Diegues, se somam aos realizados pelas fontes oficiais do governo. Cineastas retrataram, por documentário ou por enredo fictício, as mudanças que aconteceram na nova capital.

O documentarista Vladimir Carvalho ${ }^{3}$ aponta a vocação natural de Brasília para o cinema, não somente pela questão estética de sua natureza e de sua arquitetura, mas, principalmente, pela saga que representa e por ter nascido com o cinema, a captá-la e representá-la.

Ao contrário do que aconteceu com os pioneiros do cinema em todo o mundo há mais de cem anos: eles já encontraram o cenário pronto, as cidades estavam ali há séculos. Brasília, não. Brasília veio à luz sendo filmada desde a pedra fundamental. (CARVALHO, 2002, p. 14)

Sua construção - considerada uma "aventura", por durar apenas três anos desde o concurso para a seleção de seu plano urbanístico (1957) até a inauguração (1960) - em uma região praticamente desabitada, o fascínio modernista e seu componente utópico de modificação de estruturas sociais, reforçado pelo discurso de união nacional que o governo difundia em diversos meios de comunicação, nutriram a narrativa da cidade como símbolo do progresso de um país que se modernizava.

Essa vocação para o cinema, percebida por Vladimir Carvalho, que trata de uma aventura que representa a busca por uma modernidade, é percebida nas primeiras imagens da capital, nas quais é importante ressaltar um número significativo de cenas aéreas e cenas que mostram as máquinas e veículos diversos utilizados na construção da cidade, assim como cenas de automóveis pela cidade, reforçando a ideia de progresso, trabalho e modernização (Figura 1, Figura 2, Figura 3, Figura 4).

onde atuava o seu principal representante: Glauber Rocha. (CALDAS e MONTORO, 2006, p. 81)

${ }^{3}$ Vladimir Carvalho, nascido na Paraíba em 1935, chegou a Brasília na década de 1970, onde foi professor do Curso de Cinema na Universidade de Brasília. Realizou diversos documentários sobre a cidade, entre eles: "Conterrâneos velhos de guerra" (1991), "Brasília segundo Feldman" (1979) e "Barra 68" (2000). Doou recentemente seu acervo da Fundação CineMemória para a Universidade de Brasília. 


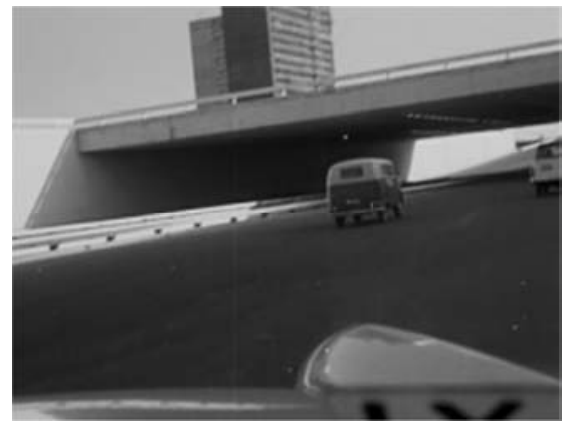

Figura 1: Still do filme "Brasília: planejamento urbano", de Fernando Cony Campos, 1964. Fonte: CTAv-MinC.

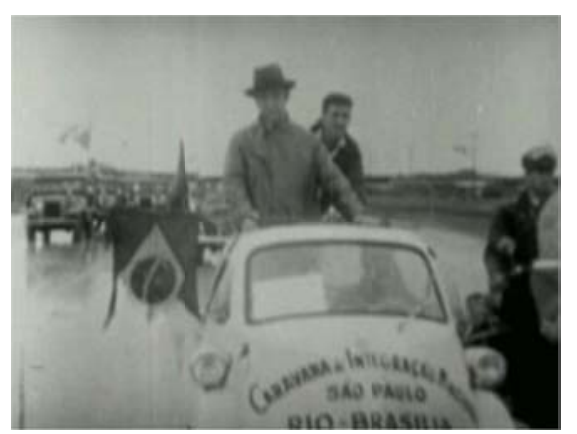

Figura 2: Still do filme "Os anos JK: uma trajetória política", de Silvio Tendler, 1980. Fonte: Caliban Filmes.

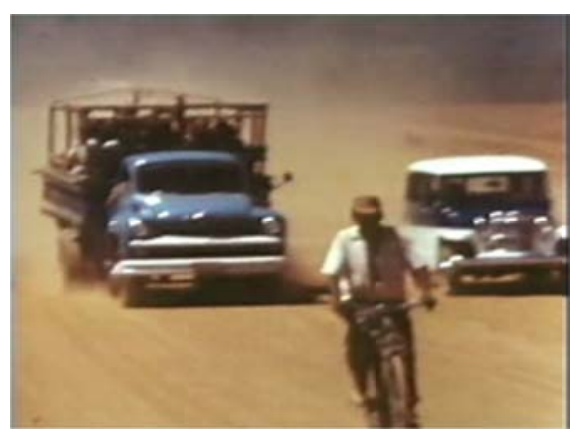

Figura 3: Still do filme "Brasília segundo Feldman", de Vladimir Carvalho, 1979. Fonte: CPCE-UnB.

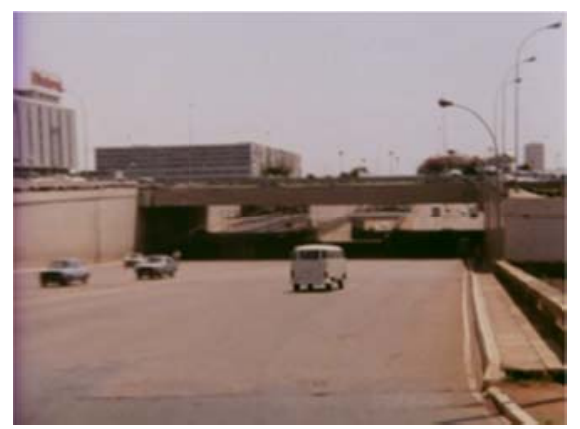

Figura 4: Still do filme "Brasília: um roteiro de Alberto Cavalcanti”, de 1982. Fonte: CTAv-MinC. 
A partir do paralelo, que se verifica entre a experiência cotidiana dos percursos (de automóvel ou a pé) e sua representação nos filmes, buscouse contrapor a análise da filmografia brasiliense com a história e o cotidiano da capital. A pesquisa busca, a partir dessa observação, estabelecer uma narrativa de compreensão histórica, pela seleção de alguns filmes de Brasília - documentários, ficções, longas e curtasmetragens - que trazem a representação da vivência dos espaços da cidade no movimento fluido de seus percursos.

Esses percursos são entendidos aqui como os trajetos realizados pela cidade, que tratam das experiências espaciais e as narrativas urbanas resultantes dessa experiência. $\mathrm{O}$ paradigma da rua, que no caso de Brasília, incorpora o ideário moderno das grandes vias de circulação, assim como a livre circulação de pedestres, pode servir de ponto de partida para a análise das experiências urbanas, contemplando também os percursos em velocidade do automóvel, tão presente nas representações cinematográficas.

Brasília produziu um acervo de mais de 500 filmes ${ }^{4}$ e nessa extensa filmografia encontram-se materiais que têm esta cidade como personagem ou como cenário, o filme narra Brasília; seu espaço participa das relações, interfere, modifica e não é apenas pano de fundo. Portanto, o objetivo do trabalho é entrar em contato com as narrativas urbanas decorrentes dessa experiência de fluxo e apropriação dos espaços nos percursos pela cidade - na errância -, para verificar de que maneira se construiu em Brasília um sentido de lugar a partir dessa experiência urbana, que não está fixa, mas em movimento constante.

O simples ato de errar pela cidade pode assim se tornar uma crítica ao urbanismo como disciplina prática de intervenção nas cidades. Essa crítica pode ser vista em diferentes formatos, através de diferentes narrativas urbanas artísticas - literárias, etnográficas, fotográficas, cinematográficas, musicais, cartográficas, etc. - realizadas pelos errantes a partir de suas experiências de errar pela cidade. (JACQUES, 2012, p. 30)

Assim, no primeiro capítulo percorre-se a cidade industrial e algumas das diversas teorias que permearam a cidade e suas reformulações nos séculos XIX e XX, promovendo a sua modernização. Buscou-se compreender os processos da modernidade e perceber de que maneira

\footnotetext{
${ }^{4}$ De acordo com a pesquisadora Berê Bahia foram catalogados 511 filmes brasilienses que participaram de mostras competitivas a partir de 1969 (ano do primeiro filme brasiliense na competição do Festival de Brasília) e da Mostra Brasília, a partir de 1996. (BAHIA, 2012, p. 8). Portanto, percebe-se que a produção vai muito além desses mais de 500 filmes, pois nesse número não estão somados muitos dos realizados pelos cursos de cinema, filmes educativos, documentários e reportagens para televisão ou filmes cujos diretores e produtores não inscreveram para o Festival.
} 
estes foram absorvidos e representados nas artes e nas atitudes: na arquitetura, no urbanismo e no cinema, principalmente. O capítulo faz um percurso pelas vanguardas artísticas, nas artes plásticas, no cinema, e pelas formulações e realizações urbanas, investigando a gênese do urbanismo moderno.

O segundo capítulo voltou-se à cidade brasileira, quando foi possível perceber a representação da modernidade como forma de uma busca de identidade nacional. Esse capítulo dá continuidade à investigação sobre os preceitos ideológicos, empreendidos pelo Movimento Moderno, que vieram a influenciar a arquitetura brasileira, notadamente no projeto de Brasília. Novamente, o foco na cidade e no cinema ajuda a reconstruir alguns fatos, tanto os ocorridos, quanto os representados ou vislumbrados pelas artes, e possibilitam compreender o período de conflitos ideológicos e as questões urbanas, no momento anterior à construção da nova capital.

No terceiro capítulo, que faz a análise efetivamente da filmografia de Brasília, foi possível encontrar, em suas representações no cinema, informações sobre como a identificação com a nova cidade foi se construindo pelos seus habitantes ao longo do tempo. A história de Brasília percorre e representa os três eixos aqui estruturados no estudo modernidade, cidade e cinema - e será analisada a partir de suas representações neste capítulo que reúne a análise de 40 filmes divididos por períodos.

Este material fornece indícios e ferramentas para uma reflexão sobre a urbanização de Brasília e a apropriação de seus espaços que em pouco mais de 50 anos teve a área urbanizada transbordada, formando um tecido urbano disperso, porém, contínuo; uma aglomeração formada por vários núcleos antes distantes. A cidade e sua formação e crescimento possibilitam a análise de uma experiência urbana pelo movimento dos percursos de uma cidade inicialmente planejada mas que, atualmente, possui as mesmas complexidades de uma grande metrópole. 


\section{Modernidade, cidade e cinema}

A partir do surgimento da indústria, no século XVIII, e do grande fluxo migratório em direção às cidades, que se tornaram um ambiente em constante convulsão, inicia-se uma experiência completamente nova: a velocidade com que ocorreram as mudanças na paisagem urbana, que durante anos havia presenciado lentas transformações, proporcionou uma nova maneira de compreender e vivenciar o tempo e o espaço. Esse turbilhão desencadeado pelas grandes descobertas, novas tecnologias, um fenômeno urbano acelerado pelo crescimento da produção e circulação, uma consequente aceleração das trocas e do ritmo de vida trouxeram mudanças e transformações no espaço físico e nas estruturas sociais, promovendo novas maneiras de viver, pensar e representar a vida urbana.

É este processo que se convenciona chamar de modernidade e abrange uma diversidade de conceitos e maneiras de compreender as numerosas transformações que ocorreram - e ainda refletem - nas estruturas sociais, políticas, econômicas e culturais. Como fio condutor deste capítulo, a modernidade e seus processos servem como embasamento para análise das transformações no ambiente urbano e de como foram representadas essas experiências de transformações fugazes e efêmeras da cidade moderna.

Essas questões serão tratadas em quatro partes, sendo a primeira relativa às representações teóricas da modernidade, presente nos relatos de autores como Georg Simmel ("A metrópole e a vida mental", 1902), Charles Baudelaire e Walter Benjamin ("A obra de arte na era de sua reprodutibilidade técnica", 1936), que representam, entre outras interpretações, narrativas de uma nova experiência de tempo e espaço, úteis para a compreensão deste novo ambiente moderno. De fato, a maneira distinta de experimentar o tempo é onde se verifica a nova sensibilidade moderna. Para autores que investigam esses processos da modernidade atualmente, entre eles David Harvey (2011) e Zygmunt Bauman (2001), "a modernidade começa quando o tempo e o espaço são separados da prática da vida e entre si, e assim podem ser teorizados como categorias distintas". (BAUMAN, 2001, p. 15 e 16).

Na segunda parte, buscou-se focar nas representações artísticas; nos movimentos de vanguarda e na importância dos conceitos que desenvolveram e concentraram; mas o surgimento do cinema como principal instrumento de representação da velocidade, do movimento e do fluxo das cidades do século XX, será analisado, separadamente, na quarta parte. 
Assim, na terceira parte, com viés mais histórico, percebe-se a paisagem urbana moderna e o ambiente que propiciou o nascimento da urbanística, fazendo-a participante dos processos de democratização do espaço da cidade. As teorias sobre o planejamento da cidade, a legislação e as tentativas de reformulações que buscaram alterar, no sentido de melhorar, a vida e a convivência no ambiente urbano. A presença da indústria e da máquina neste processo de alteração da paisagem estabelece a crença de que seu poder seria capaz de libertar e, ao mesmo tempo, controlar os processos sociais em uma nova direção. A máquina foi, nesse sentido, a grande personagem representada nas vanguardas e teorias do final do século XIX e início do XX.

A quarta parte faz um breve caminho desde o surgimento do cinema, quando, em função de sua filiação técnica e industrial e também pelo dinamismo da imagem, em sintonia com as novas condições da experiência, torna-se instrumento e representação de modernidade, captando imagens e cenas de cidades no mundo todo. Foca posteriormente nas vanguardas artísticas dos anos 20 , quando o cinema se legitima, promovendo manifestos e inserindo-se na sociedade como parte da cultura dominante e erudita, chegando ao Cinema Moderno das décadas de 1950 e 1960, e é percebido como eficaz instrumento de conscientização em face ao quadro de conflitos sociais, ganhando a rua e influenciando o novo cinema ao redor do mundo, inclusive no Brasil.

\subsection{Experiências da modernidade e o sentido de lugar: angústia e desejo de transformação.}

O autor David Harvey, em "Condição pós-moderna: uma pesquisa sobre as origens da mudança cultural” (2011), faz o seu percurso por meio da modernidade iniciando com a sentença de Baudelaire: "A modernidade é o transitório, o fugidio, o contingente; é uma metade da arte, sendo a outra, o eterno e o imutável" (1863, apud HARVEY, 2011, p. 21). E demonstra dessa maneira como a modernidade é impregnada de um paradoxo, de sentidos conflitantes entre o fixo e o efêmero, o passado e o presente, quando a instabilidade se aproxima da eternidade.

Para o "homem metropolitano", este que vivencia a metrópole, a modernidade significou a conquista da liberdade. Para Georg Simmel, em "A metrópole e a vida mental" (1902, p.12), é uma liberdade que pode ser vista como indiferença e solidão em meio à multidão metropolitana e que não se reflete em realização e conforto para a vida emocional. $O$ autor faz uma análise da relação entre as consciências individuais e a cidade moderna e mostra a inquietação quanto ao rompimento experimentado 
pelo homem moderno, que vem em busca de maior liberdade e autonomia da tradição e herança cultural e moral. Busca responder "como a personalidade se acomoda nos ajustamentos às forças externas" (SIMMEL, 1979, p. 12), sendo que a luta do homem moderno não é mais somente por uma existência física, mas por uma busca pela preservação de autonomia e individualidade em meio a uma vida urbana, que segundo ele é concentradora e geradora de múltiplos estímulos, imagens e informações.

Para Hilde Heynen (1999), a modernidade é descrita muitas vezes como uma condição de homelessness, termo que traduz a sensação descrita por Simmel, de sentir-se só em meio à multidão, ou de sentir-se não pertencendo a lugar nenhum. A autora esclarece:

\footnotetext{
O desenvolvimento tecnológico da produção e a organização burocrática da vida social, que são as duas operadoras mais importantes do processo de modernização, dependem de princípios como a racionalidade, anonimato, e uma abstração crescente nas relações sociais. Isto leva a uma pluralização da vida social: as pessoas vivem em seu trabalho, em casa, em clubes e sociedades, cada vez em diferentes situações, onde outras normas e regras podem ser aplicadas, e que podem até mesmo ser mutuamente contraditórias. Além disso, esses mesmos contextos são suscetíveis de se alterar ao longo do tempo. (HEYNEN, 1999, p. 14) $)^{5}$
}

Mas é preciso compreender como é este ambiente metropolitano, que segundo Heynen e Simmel, incita estas inquietações. A condição de vida e a miséria presente no ambiente da cidade industrial dos séculos XVII ao XIX, acrescidos de uma gradativa libertação e confiança num futuro melhor, trazem uma mudança na maneira de perceber e descrever este ambiente, que desperta questionamentos.

\footnotetext{
A pobreza - condição suportada há séculos sem esperança de alternativas razoáveis - é agora reconhecida como "miséria”, quer dizer, é vista na perspectiva moderna de um mal que pode e deve ser eliminado com meios à disposição. A. Bevan escreve: "por miséria entendo uma consciência geral de privações não necessárias - e esta é a condição normal de milhões de pessoas na moderna cidade industrial - unidas a um profundo sentimento de desilusão e de insatisfação pela situação local atual. De nada serve replicar que as coisas sempre estão melhor que outrora. As pessoas vivem no presente, não no passado. $\mathrm{O}$ descontentamento nasce do contraste entre aquilo que se sabe ser possível e o que efetivamente existe. Há a universal e justificada convicção de que a grande massa de homens e mulheres se encontra pior do que poderia estar". (BENEVOLO, 1994, p. 46)
}

\footnotetext{
${ }^{5}$ Tradução livre: "The technological development of production and the bureaucratic organization of social life, which are the two most important carriers of the process of modernization, depend on principles such as rationality, anonymity, and an increasing abstraction in social relations. This leads to a pluralization of social life: people live at their work, at home, in clubs and societies, each time in different situations where other norms and rules may apply and that may even be mutually contradictory".
} 
Essa mudança de perspectiva, descrita acima por Benevolo, evidencia uma mudança de comportamento, em que no lugar da resignação aparece uma crença na possibilidade de transformação, um ímpeto gerado a partir da extrema insatisfação com a situação presente. A modernidade trata objetivamente com uma evolução socioeconômica e subjetivamente com a maneira de viver e refletir sobre toda a mudança trazida pela modernização, através de movimentos artísticos ou formulações teóricas.

Hilde Heynen (1999, p. 11-15) distingue, assim, os conceitos programáticos e transitórios da modernidade: "Há uma interpretação da modernidade como sendo em primeiro lugar e antes de tudo um projeto de progresso e emancipação. A concepção programática a vê, principalmente a partir da perspectiva do novo, daquilo que distingue a época atual da que a precedeu" ${ }^{6}$. Mas, "em contraste, há um nível de significado no moderno: o transitório ou momentâneo, o qual tem sido enfatizado pela arte moderna" 7 . O paradoxo gerado a partir desses dois conceitos se realiza por meio de um fluxo contínuo, do movimento em direção ao futuro, que é efêmero.

Na definição de Marshall Berman, em "Tudo que é sólido desmancha no ar: a aventura da modernidade" (1986), o autor analisa esse paradoxo como a angústia que movimenta e gera as transformações, associando-o à imagem de um turbilhão, que desmancha tudo o que é (era) sólido:

\footnotetext{
Existe um tipo de experiência vital - experiência de tempo e espaço, de si mesmo e dos outros, das possibilidades e perigos da vida - que é compartilhada por homens e mulheres em todo o mundo, hoje. Designarei esse conjunto de experiências como "modernidade". Ser moderno é encontrar-se em um ambiente que promete aventura, poder, alegria, crescimento, autotransformação e transformação das coisas ao redor mas ao mesmo tempo ameaça destruir tudo o que temos, sabemos e tudo o que somos. A experiência ambiental da modernidade anula todas as fronteiras geográficas e raciais, de classe e nacionalidade, de religião e ideologia: nesse sentido, pode-se dizer que a modernidade une a espécie humana. Porém, é uma unidade paradoxal, uma unidade e desunidade: ela nos despeja a todos num turbilhão de permanente desintegração e mudança, de luta e contradição, de ambiguidade e angústia. Ser moderno é fazer parte de um universo no qual, como disse Marx, "tudo o que é sólido desmancha no ar". (BERMAN, 1986, p. 15)
}

A modernidade representa o arquétipo de uma jornada de destruição e reconstrução. A “destruição criativa”, presente na definição de Berman,

\footnotetext{
${ }^{6}$ Tradução livre: "The advocates of the former interpret modernity as being first and foremost a project, a project of progress and emancipation. They emphasize the liberating potential that is inherent in modernity. A programmatic concept views modernity primarily from the perspective of the new, of that which distinguishes the present age from the one that preceded it".

${ }^{7}$ Tradução livre: "In contrast, the transitory view stresses the third level of meaning implied in the modern: the transient or momentary. (...) Throughout the development of modern art, this moment of transitoriness has been emphasized".
} 
assim como na jornada de "Fausto", de Goethe $(1749-1832)$, consiste na constante movimentação causada pela angústia em busca de algo novo e pela destruição do que existe. Afinal, "como poderia um novo mundo ser criado sem se destruir boa parte do que viera antes?”. (HARVEY, 2011, p. 26)

Esta será a principal questão tratada pelas vanguardas no final do século XIX e início do XX: o descompasso gerado entre a realidade e as possibilidades vislumbradas de renovação, resultado de uma eterna reconstrução "autofágica" em busca de dissecar a própria linguagem da cidade. Retratadas pelos pintores e pelos fotógrafos que espalharam sua imagem pelo mundo e, posteriormente, pelos cinematógrafos, tiveram os movimentos da vida cotidiana, seus edifícios, máquinas, fábricas, automóveis e personagens gravados quadro a quadro na película. Alternando-se em ideologias, linguagens e conceitos, em busca de representar a realidade efêmera e projetar o futuro, novo a cada dia, as vanguardas artísticas tiveram o importante papel de representar esses paradoxos na literatura, nas artes, no cinema, na arquitetura.

\subsection{Vanguardas artísticas: representações do efêmero}

A cidade, enquanto espaço compartilhado, capaz de gerar e assimilar a diversidade, como palco das transformações, passa a ser o principal foco dos artistas modernos. Para lidar com a efemeridade, o fragmentário e o caos em busca do "eterno e imutável" de Baudelaire, ou seja, de uma metade que falta; coube aos artistas, pensadores e arquitetos fazê-lo a partir do desempenho de uma "função heroica" para não só compreender o processo, mas iniciar a sua mudança (HARVEY, 2011, p. 28), e isso viria a acontecer a partir de uma estratégia "conscientemente estética".

Se o fluxo e a mudança, a efemeridade e a fragmentação formavam a base material da vida moderna, então a definição de uma estética modernista dependia de maneira crucial do posicionamento do artista diante desses processos. $\mathrm{O}$ artista individual podia contestá-los, aceitá-los, tentar dominá-los ou apenas circular entre eles, mas o artista nunca os poderia ignorar. (BAUDELAIRE apud HARVEY, 2011, p. 29)

Os românticos, os realistas, os impressionistas marcaram suas impressões e visões sobre o que representava a nova experiência da cidade. Os artistas modernos procuraram digerir as grandes mudanças tentando entendê-las sensivelmente e interferir no seu andamento. A criação de uma nova linguagem, compatível com as que estavam revolucionando as técnicas, as ciências e as cidades, era o objetivo dos artistas modernos que, ao tematizar o ambiente urbano, evitavam mimetizá-lo ou simplesmente descrevê-lo. 
Essa nova linguagem e a criação de novos códigos buscavam a representação do "eterno" e o "imutável" em meio a todo o caos da vida moderna. $\mathrm{O}$ artista concentra os elementos da vida cotidiana da cidade em sua efemeridade, sintetizando e extraindo do instante a eternidade almejada. Assim, o tempo passa a ter papel importante, pois é pelo seu congelamento e representação (ou espacialização) que se chega à eternidade esperada. (HARVEY, 2011)

O instante congelado, possível de ser transportado e reproduzido, possibilitado pela fotografia fixa, aboliu as barreiras de espaço criando "simulacros transportáveis" (SOLÀ-MORALES, 1994). Com a fotografia ocorre outra grande mudança: a liberação da mão das responsabilidades artísticas, transferindo essa responsabilidade para o olho e permitindo uma rápida reprodução do instante fixado na imagem. Segundo Walter Benjamin, em seu artigo "A obra de arte na era da reprodutibilidade técnica" (1936), a reprodutibilidade da obra de arte representa um violento abalo da tradição, ao substituir uma existência única por uma existência serial, ao retirar seu valor de autenticidade e atrofiar sua aura e sua história (ausência do aqui e agora da obra de arte).

Segundo Solà-Morales (1995, p. 183), a "percepção que temos hoje da arquitetura e das cidades é esteticamente reelaborada pelo olho e pela técnica fotográfica". Foi a fotografia que construiu uma relação inseparável com nosso conhecimento da arquitetura moderna e das grandes cidades. A manipulação das imagens, os enquadramentos e os pontos de vista influenciaram incisivamente a percepção da arquitetura. Como exemplo disso, no início do século $\mathrm{XX}$ as fotografias e, em especial, as fotomontagens exibiram a acumulação e a justaposição dos elementos urbanos, mostrando sua condição fragmentária e densa, como a fotomontagem de Paul Citroen (Figura 5), para explicar a experiência das grandes cidades. $\mathrm{O}$ ambiente urbano representado era caótico, fragmentado, transitório: o espaço no tempo e a velocidade.

A partir das pesquisas da fotografia, o cinema vem captando as imagens das cidades e seus fluxos desde o século XIX, sendo amplamente utilizado como representação de cenas cotidianas e em pesquisas estéticas. Em "O cinema e a invenção da vida moderna", seus autores, Charney e Schwartz, argumentam que a atenção moderna foi concebida não somente como visual e móvel, mas também fugaz e efêmera - a visão em movimento - e que "as formas modernas de experiência dependiam não apenas do movimento, mas dessa junção de movimento e visão" (CHARNEY e R.SCHWARTZ, 2004, p. 22). 


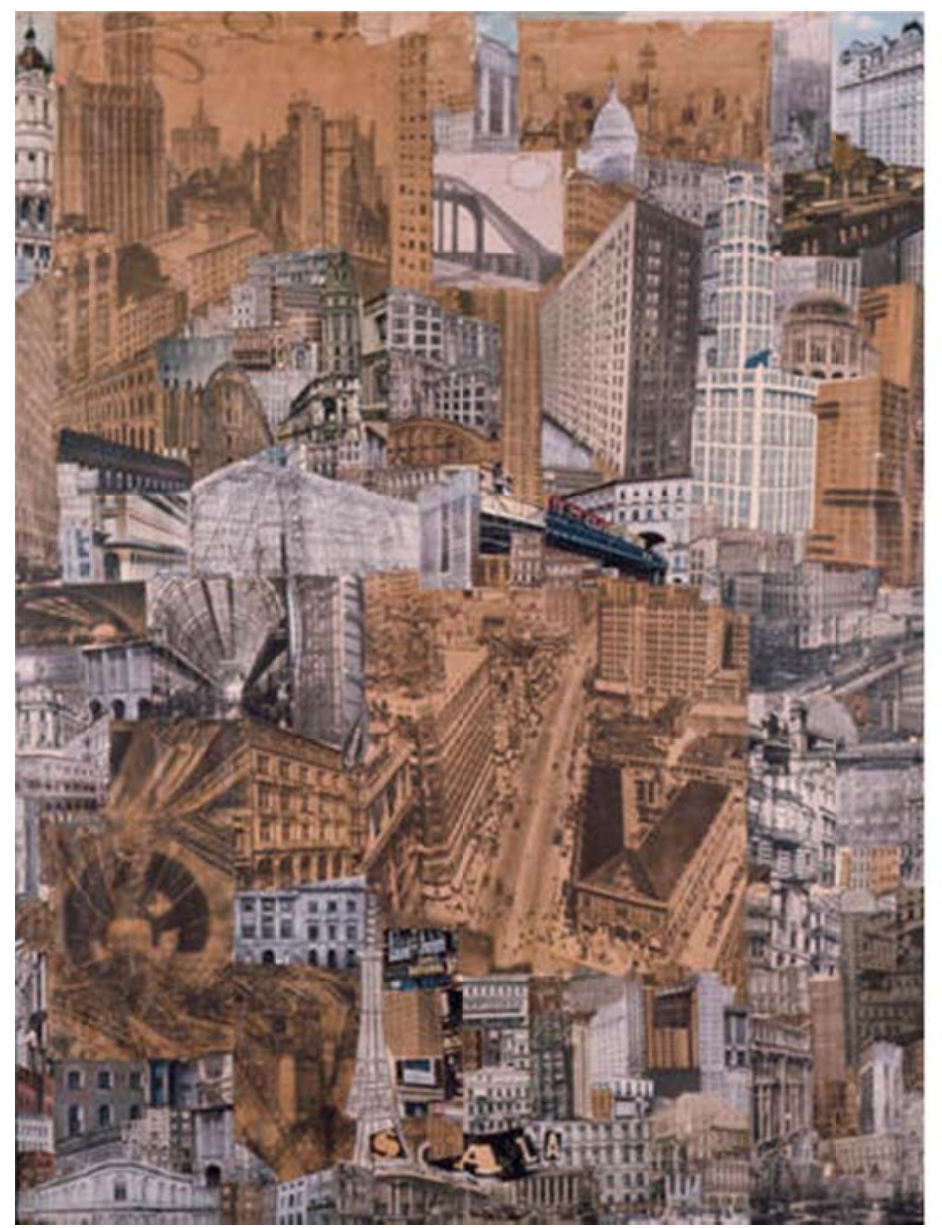

Figura 5: Paul Citroen, "Metropolis" (Großstadt), 1923. Fonte: Solà-Morales, "Representaciones: de la ciudaid capital a la metropoli”, 1994.

A figura 6 mostra um dos diversos estudos de movimento criados no período que antecedeu o cinema, por Eadweard Muyridge, que também criava aparelhos para projetar as sequências das "fotografias em movimento" ou motion-pictures. Segundo Costa (2006, p. 18), a quantidade desses "brinquedos óticos" indica o fascínio pelo movimento e sua reprodução; e Xavier (1978, p. 23) acrescenta que "não é por acaso que a obtenção da imagem em movimento foi o grande horizonte, mais do que a incrementação de poderes reprodutivos da fotografia (cor, relevo, etc.)." 


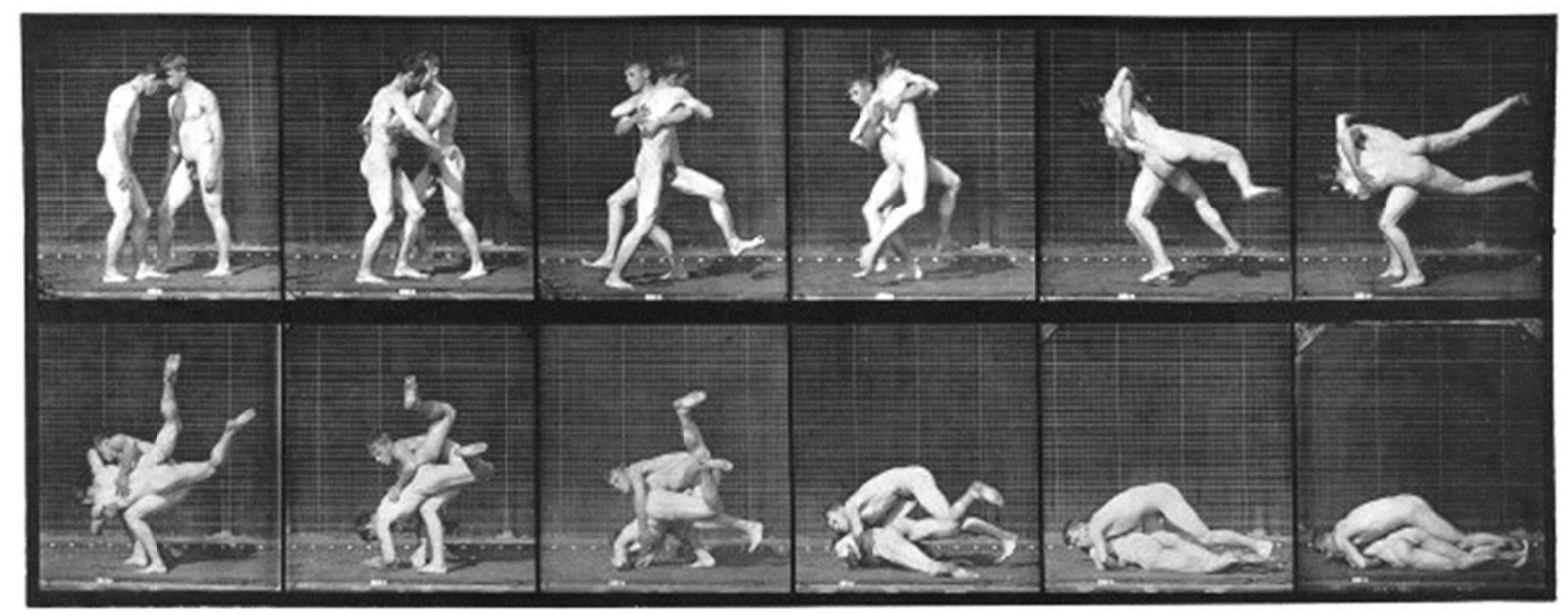

Figura 6: Sequência de movimento "Two males (nude) wrestling Graeco-Roman", 1872-1885, por Eadweard James Muybridge (1830 -1904). Fonte: http://www.racollection.org.uk, acesso em 03.02.2014.

A experiência causada, por exemplo, pela cena da "Chegada do trem na Estação Ciotat" " , exibida em 1896, pela novidade da perspectiva inusitada da câmera: ao produzir a ilusão de que o trem estava avançando em direção à plateia, causando espanto e entusiasmo, foi considerado o marco inicial do cinema, mesmo não sendo a primeira projeção do que eram as chamadas "vistas animadas" e que mostravam cenas do cotidiano.

Este filme, feito por Auguste Lumière, foi simplesmente o resultado da invenção da câmera, da película e do projetor. O espetáculo, que só dura meio minuto, mostra um trecho da plataforma ferroviária banhada pela luz do sol, damas e cavalheiros caminhando por ali, e o trem que surge do fundo do quadro e avança em direção à câmera. À medida que o trem se aproximava, instaurava-se o pânico na sala de projeção, e as pessoas saíam correndo. Foi neste momento que nasceu o cinema, e não se tratava de técnica ou de uma nova maneira de reproduzir o mundo. Surgira, na verdade, um novo princípio estético. Pela primeira vez na história das artes, na história da cultura, o homem descobria um modo de registrar uma impressão do tempo. (TARKOVSKI, 1990, p. 71)

A busca por fixar e representar instantes únicos diante das distrações e sensações da modernidade inspirou as vanguardas artísticas, nas artes, pintura, fotografia e cinema, em uma constante tentatival de entender e ordenar o caos e configurar uma nova paisagem-cenário para as cidades de sua época. Mas, ao almejar uma profunda ruptura com o passado, os movimentos artísticos manifestaram uma visão polarizada, dividindo o mundo entre novo e velho, modernidade e tradição.

O questionamento de Harvey (2011, p. 26): "Como poderia um novo mundo ser criado sem se destruir boa parte do que viera antes?" é essencial para a compreensão da motivação dos movimentos artísticos de vanguarda na Europa do século XX. 
Certos movimentos de vanguarda mobilizaram-se para fins revolucionários, fundindo sua arte com a cultura popular, outros buscavam impor uma linguagem estética e um padrão de beleza. Mas, de acordo com Bassani (2003, p. 52), "as decorrências dessas visões para as artes são de extrema complexidade e o ponto central das discussões está em torno da ideologia e da componente utópica do pensamento das vanguardas". E, essencialmente, a construção de uma nova sociedade era a principal proposta das vanguardas.

Os movimentos de vanguarda que surgiram um após o outro - cubismo, dadaísmo, expressionismo e surrealismo (Figuras 7, 8, 9 e 10) representando a simultaneidade, usando da montagem e: da colagem ao tentar representar o equilíbrio da eternidade ao captar o instante, acabaram acelerando e produzindo o próprio desequilíbrio. A numerosa quantidade de proposições e visões deve-se a esta eterna busca da representação de um momento de rupturas constantes.

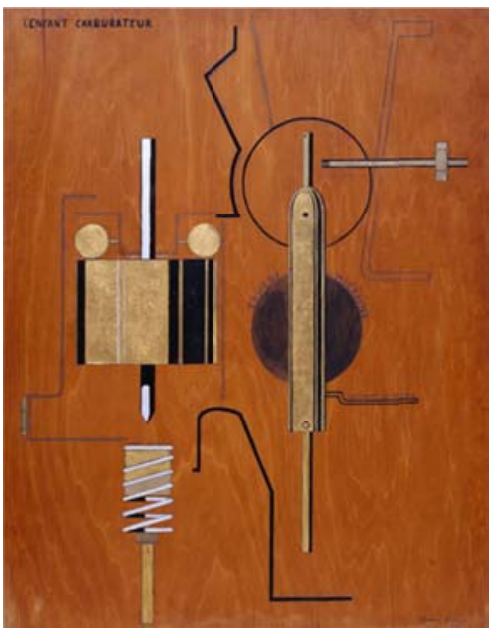

Figura 7: "L'Enfant Carburateur", de Francis Picabia, dadaísmo,1919. Fonte: http://www.guggenheim.org, acesso em 03.04.2014.

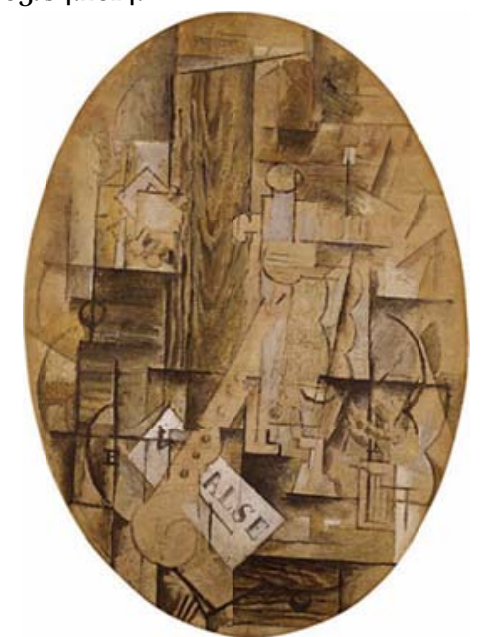

Figura 8: "La Clarinette", de Georges Braque, cubismo,1912. Fonte: http://www.guggenheim.org, acesso em 03.04.2014. 


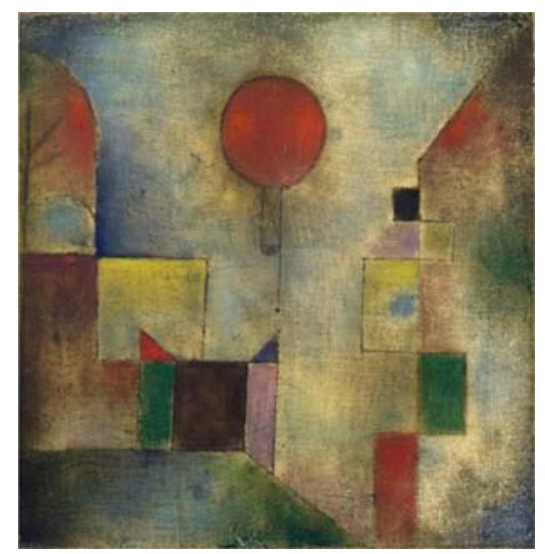

Figura 9: "Roter Ballon", Paul Klee, expressiomismo, 1922. Fonte: http://www.guggenheim.org, acesso em 03.04.2014.

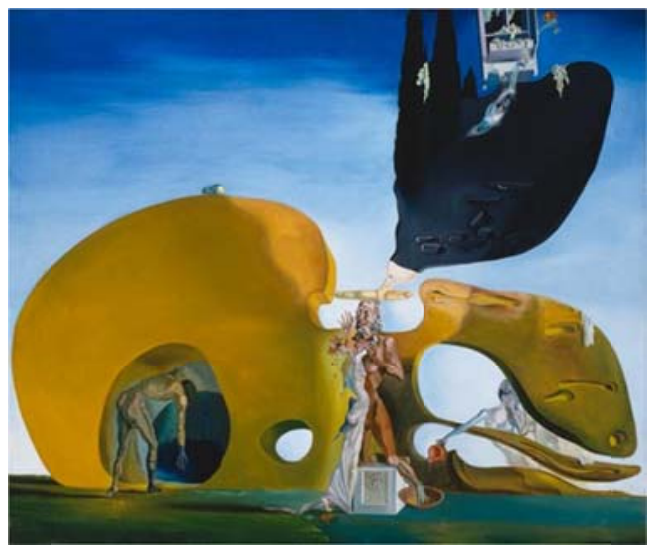

Figura 10: "La Naissance des désirs liquides", Salvador Dalí, surrealismo, 1932. Fonte: http://www.guggenheim.org, acesso em 03.04.2014.

Walter Benjamim (1936) ressalta o papel social dos artistas modernos, nutrido principalmente pela crescente possibilidade de reprodução de imagens (e com elas, as ideias) que divulgavam, questionavam, digeriam e recomeçavam um ciclo, ele mesmo alimentado pelo fascínio do recomeço.

A capacidade técnica mutante de reproduzir, disseminar e vender livros e imagens a públicos de massa, e a invenção da fotografia e, depois, do filme, mudaram radicalmente as condições materiais de existência dos artistas e, portanto, seu papel social e político. E, sem relação com a consciência geral do fluxo e da mudança presente em todas as obras modernistas, um fascínio pela técnica, pela velocidade e pelo movimento, pela máquina e pelo sistema fabril, bem como pela cadeia de novas mercadorias que penetravam na vida cotidiana, provocou uma ampla gama de respostas estéticas que iam da negação à especulação sobre possïbilidades utópicas, passando pela imitação (apud HARVEY, 2011, p. 31).

Como exposto na citação acima, outra questão trazida por Benjamin, de como a investigação estética das vanguardas pautou-se, em sua maioria, na busca da representação do movimento, do fluxo e da 
simultaneidade, utilizando a cidade como referência, como alvo de sua crítica e como principal cenário. De acordo com Harvey (2011, p. 30), ao internalizar o próprio "turbilhão de ambiguidades, de contradições e de mudanças estéticas pulsantes, o modernismo buscava afetar a estética da vida diária". Os fatos da vida cotidiana, a renúncia e a revolta com a realidade, a circulação de ideias e as inquietações que a cidade promovia influenciaram incisivamente a sensibilidade estética e é onde se verifica uma nova experiência da modernidade.

Os principais movimentos de vanguarda, que se sucederam a partir da década de 1910, como o movimento do futurismo italiano, por exemplo, defendiam uma modernidade por meio de uma atitude de renúncia à opressão do passado, ao glorificar o mundo moderno e a cidade industrial. Como é possível perceber em seu manifesto, publicado em 1909:

Camaradas, nós afirmamos que o triunfante progresso da ciência torna inevitáveis as transformações da humanidade, transformações que estão cavando um abismo entre aqueles dóceis escravos da tradição e nós, livres modernos, que acreditamos no radiante esplendor do nosso futuro. (Manifesto Futurista, Marinetti, 1909).

O Manifesto Futurista, escrito pelo poeta italiano Filippo Tommaso Marinetti, e publicado no jornal francês "Le Figaro" em 20 de fevereiro de 1909, girava em torno do conceito básico de movimento, concentrados num conjunto de ideias como velocidade, multiplicidade e simultaneidade, percebidas nas afirmações: "O Tempo e o Espaço morreram ontem. Vivemos já o absoluto, pois criamos a eterna velocidade onipresente". Sua estética se articulava como uma visão cinematográfica de mundo, tendo o movimento e velocidade representados inclusive nas pinturas e nas fotomontagens. $\mathrm{O}$ cinema é visto pelos futuristas como a nova forma de expressão artística que atenderia à necessidade de uma expressividade plural e múltipla, como declara o "Manifesto da Cinematografia Futurista", assinado pelo grupo de artistas futuristas, entre eles Marinetti e Balla, em 1916. (XAVIER, 1978, p. 34).

Nos manifestos de Boccioni e Marinetti sobre a escultura ${ }^{8}$, um conjunto de referências intelectuais e estéticas que traçam a arquitetura futurista, descrevem os esboços de Antonio Sant'Elia da "Città Nuova", em 1912 (Figura 11), e aproxima-se e influencia a estética do construtivismo na Rússia pós-revolução (Figura 12). Os movimentos das vanguardas russas geraram grande influência na cultura e na ideologia da arquitetura moderna, a partir de 1917, quando diante da Revolução Bolchevique e do contexto revolucionário, promoveram a mobilização em torno dos interesses da revolução com propostas concretas para a vida do povo.

\footnotetext{
8 "Manifesto técnico da escultura futurista" (Boccioni, 1912) e "O esplendor geométrico e mecânico" (Marinetti, 1914).
} 

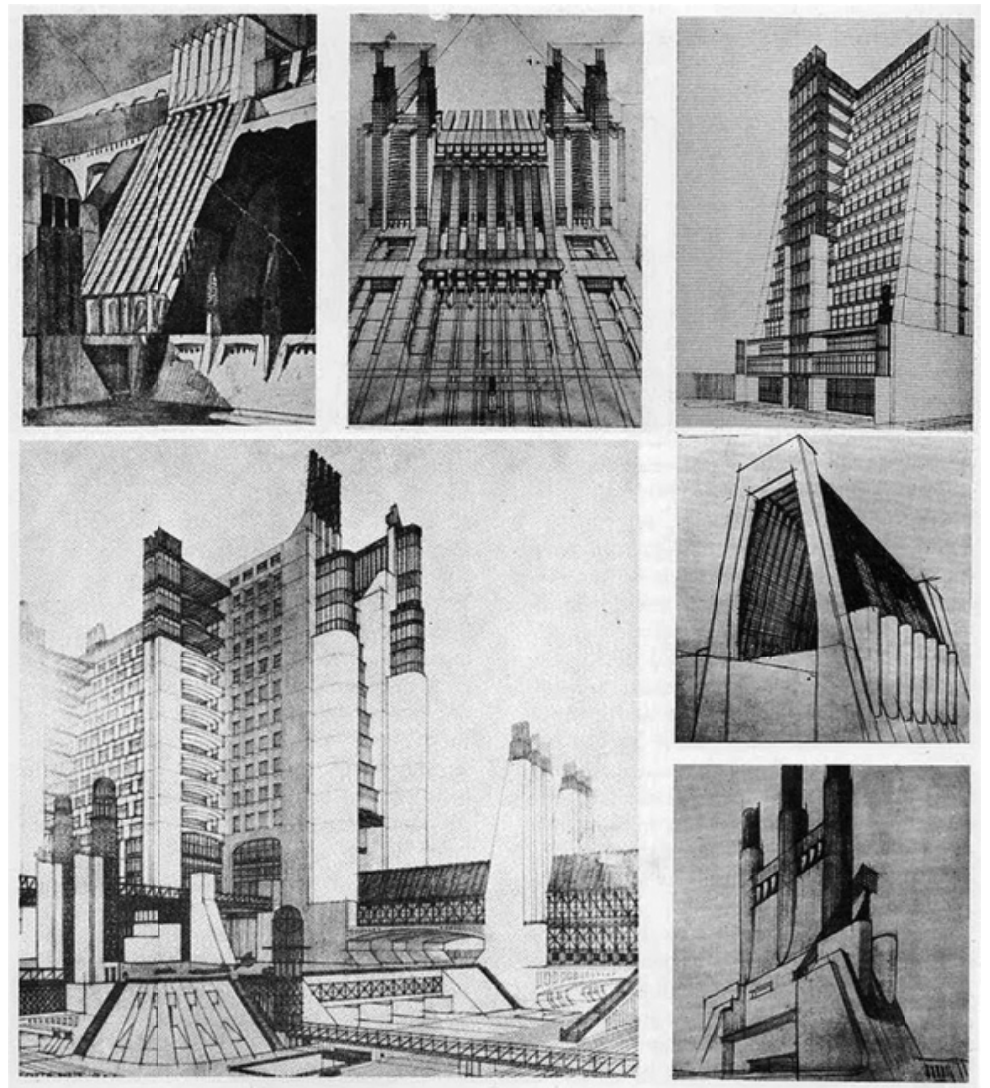

Figura 11: “Città Nuova”, Antonio Sant'Elia, 1912. Fonte: Frampton, 2008.

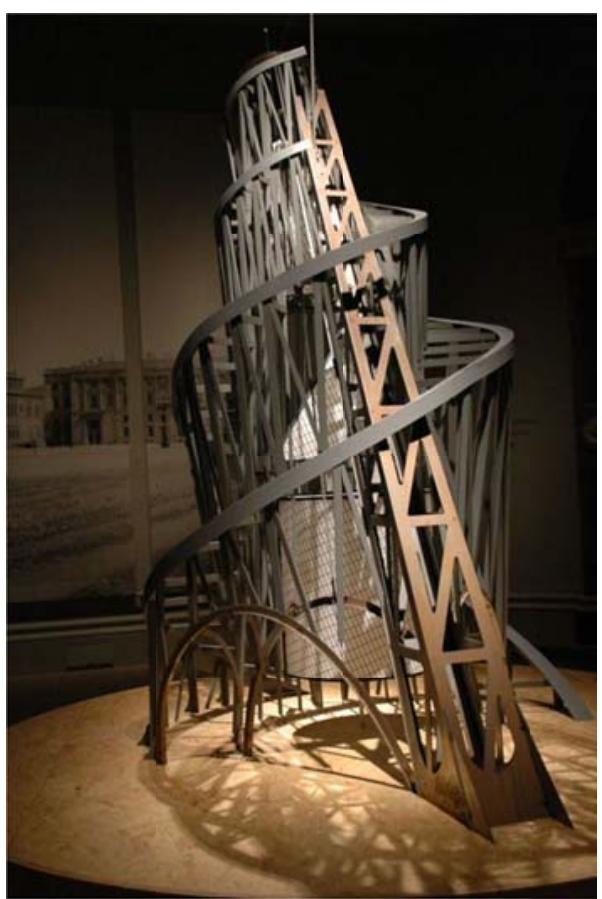

Figura 12: "Monumento à Terceira Internacional", de Vladimir Tatlin, exposto em 1920, seria erguido no centro de Moscou. A foto é de sua maquete, exposta na Royal Academy of Arts de Londres, em 2011. Fonte: http://www.racollection.org.uk 
No movimento denominado construtivismo (1917-1933), a pintura e a escultura que usavam de formas e cores básicas e geométricas eram concebidas como construções - e não como representações -, guardando proximidade com a arquitetura.

Todas essas convicções me forçam a procurar na escultura não a forma pura, mas o ritmo plástico puro: não a construção de corpos, mas a construção da ação dos corpos. Assim, tenho por ideal não uma arquitetura piramidal (estado estático), mas uma arquitetura em espiral (dinamismo). Além do mais, minha inspiração procura, através da pesquisa diligente, uma fusão completa do ambiente e do objeto mediante a interpenetração dos planos. (BOCCIONI, 1913 apud FRAMPTON, 2008, p. 97).

De acordo com a citação e as imagens acima é possível perceber que o dinamismo perseguido pela escultura, através do ritmo e da ação dos corpos e do ambiente no objeto, é levado também à investigação da arquitetura. Percebe-se nos esboços de Sant'Elia, na figura 11, que a arquitetura piramidal busca o dinamismo pelas transparências e pela interpenetração de planos e volumes, assim como no espiral (Figura 12) do monumento de Tatlin.

A imagem sobreposta em velocidade do futurismo, o artista Fernand Léger, com o seu filme "Ballet Mécanique" ${ }^{4}$ (Figura 13), e o cinema de Dziga Vertov e seu "Manifesto do Cinema-Olho", que será abordado no capítulo sobre o cinema, evidenciam os pontos de contato com os fluxos urbanos e a arte moderna. Ao exaltar a máquina e a "beleza da velocidade", associada ao elogio da técnica e da ciência, buscavam uma nova atitude estética por meio de outra sensibilidade - condicionada pela velocidade e pelos meios de comunicação - e propunham soluções para os problemas vividos nas grandes cidades. 

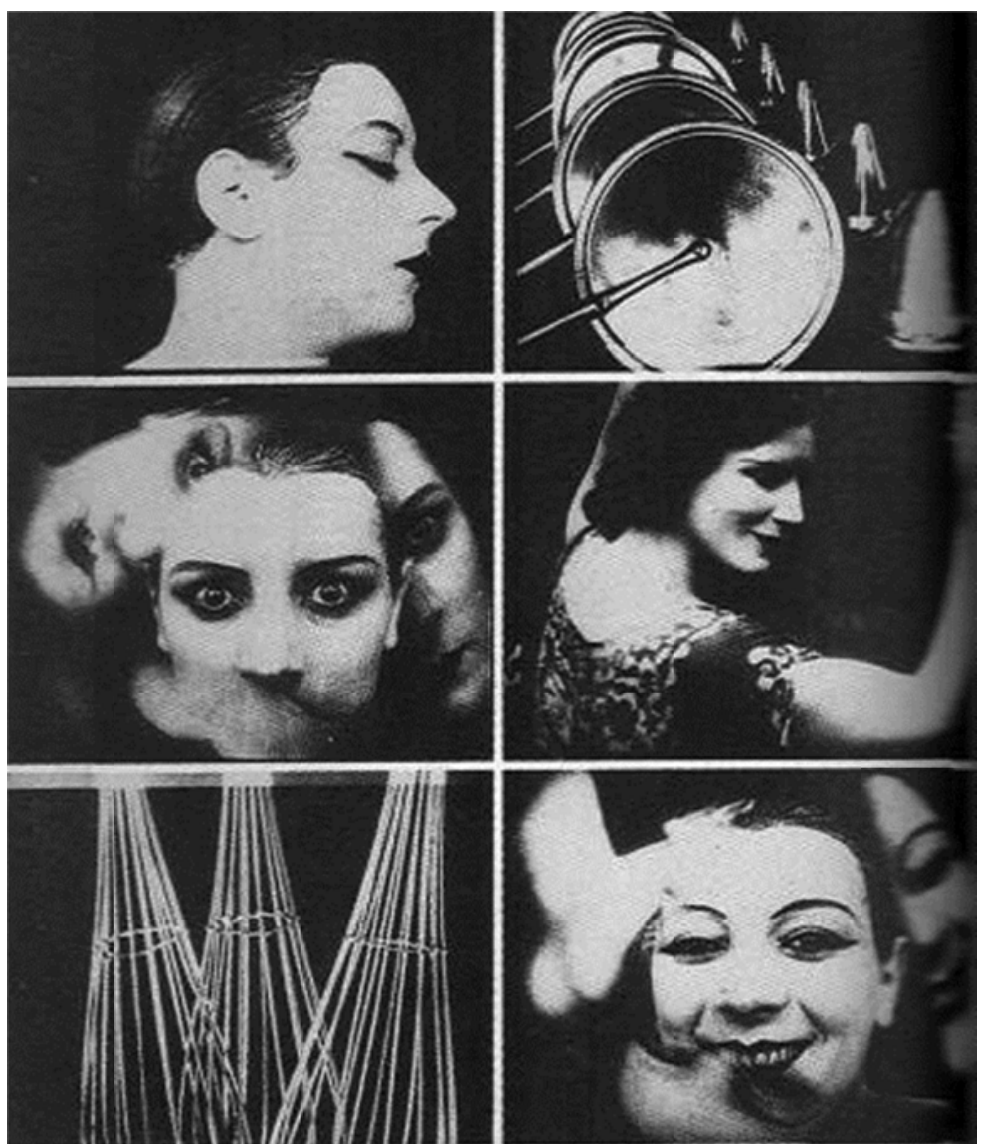

Figura 13: Imagens do filme "Ballet Mécanique", de Fernand Léger, 1924. Fonte: www.cinematheque.fr, acesso em 04.03.2013. 


\subsection{O Movimento Moderno: ideário da máquina e a materialização do transitório}

Leonardo Benevolo, em "As origens da urbanística moderna" (1994), define a cidade industrial como um "fato novo" pela rapidez com que esta cidade se transformou e estimulou mudanças, ressaltando a importância da indústria (e da máquina) e como ela representava ao mesmo tempo a causa e a expectativa de transformação:

A cidade industrial é um fato novo, surgido num tempo limitado sob os olhos das mesmas pessoas que lhe suportam os incômodos. É um fato singular, perturba os hábitos e a capacidade de compreensão dos contemporâneos, mas perece tudo menos fixo e inevitável. Ainda não se encontrou um sistema razoável para controlar os seus processos, mas parece natural que a inventiva do homem e a força das máquinas, tal como originaram esta realidade, possam também mudar-lhe o curso.

(BENEVOLO, 1994, p. 45)

Com o crescimento acelerado, a distribuição da população pelo território havia mudado radicalmente e havia carência de novos locais para fixação de maneira adequada para a população, que afluía constantemente aos aglomerados industriais, ocupando os espaços vazios disponíveis, ou construindo na periferia que rapidamente se formou e se estendeu ao redor dos núcleos primitivos. Pela descrição de Manchester feita por Engels, em 1845, fica clara a dificuldade de estabelecer algum controle ou vislumbrar alguma mudança na condição em que habitava a maioria da população, sem que para isso uma proposta radical tivesse que se colocar:

(...) Ao longo do rio estão ainda intercaladas fábricas: também aqui as construções são portanto apertadas e desordenadas, tal como na parte inferior de Long Millgate. À direita e à esquerda, uma quantidade de passagens cobertas conduzem da rua principal aos numerosos pátios, entrando nos quais se depara com uma revoltante imundície que não tem igual, particularmente nos pátios virados ao Irk, que contém as mais horrendas habitações que eu alguma vez vira. (...) Nos pátios por baixo de Ducie Bridge desce-se, além disso, por escadas estreitas e sujas, e só atravessando montões de escombros e de imundícies se consegue chegar às casas. (ENGELS apud BENEVOLO, 1994, p. 40)

Somado a isso, a política liberal procurava interferir minimamente, sem estabelecer controles na ocupação do território. Porém, a necessidade de abertura de canais de circulação, como representado na figura 14; a especialização de setores urbanos (áreas específicas de negócios, fábricas, habitação e comércio) que começava a moldar uma nova imagem da cidade, cada vez menos delimitada; e uma inevitável necessidade de lidar com a condição precária das habitações e pátios tornou irremediável a promoção de reformas urbanas e inspirou novas 
teorias a respeito da regulamentação e planejamento da ocupação do território.

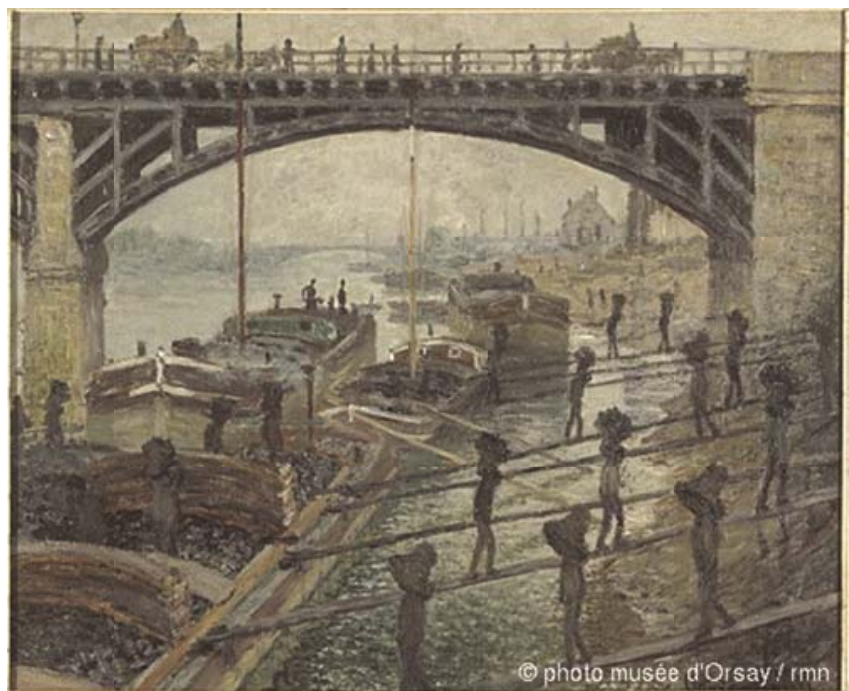

Figura 14: Claude Monet, "Les déchargeurs de charbon", cerca de 1875, Musée d'Orsay, Paris, France. www.museeorsay.fr/fr/collections/catalogue-des-oeuvres, acesso em 16.06.2013

A estrada de ferro foi responsável por inúmeras mudanças no tecido urbano, ao possibilitar que a matéria-prima e a indústria pudessem estar distantes, criando novos fluxos de circulação e promovendo novas maneiras de pensá-lo. Benevolo oferece alguns dados histtóricos a este respeito:

Devido às exigências do comércio e especialmente para o transporte das mercadorias pobres e pesadas como o carvão e os minerais ferrosos, foi renovada a rede das vias de comunicação; as incômodas estradas das freguesias foram substituídas depois de 1745 por novas estradas com portagens; os estuários e o curso dos rios navegáveis foram ligados por novos canais após os anos 1760 (...). Em 1767, R. Reynolds constrói o primeiro carril em ferro fundido para o transporte de carvão, e em 1801 entrou ao serviço a Surrey Iron Railway, a primeira empresa ferroviária para transporte de mercadorias; mas só depois de 1825, a seguir à invenção da locomotiva de Stephenson, se iniciou o desenvolvimento dos caminhos de ferro, marcando assim decisivamente os decênios seguintes. (BENEVOLO, 1994, p. 22)

Mais que isso, a estrada de ferro pode ser associada à imagem da transformação na experiência urbana, pois realinha uma complexidade de práticas, oferecendo mudanças perceptivas e ambientais da experiência da modernidade: "um colapso das experiências de espaço e de tempo por meio da velocidade", acarretando uma nova experiência do 
corpo e da percepção, "moldada pela viagem e por novos e atraentes potenciais de perigo ${ }^{9}$ e aventura (GUNNING, 2004, p. 34).

Ao apontar maneiras de incorporar esses novos fluxos às malhas tradicionais, surgiram novas propostas urbanísticas como a Cidade Linear, de Arturo Soria y Mata, em 1892 (Figura 15), que propunha amenizar o problema das superpopulações interligando dois núcleos urbanos existentes permitindo um crescimento contínuo da cidade conforme o padrão linear estabelecido, ao integrar o fato inevitável das estradas e ferrovias. A proposta previa uma des-hierarquização ao unir as áreas de trabalho e habitação a uma espinha crescente de circulação e permitir um relacionamento mais ordenado entre campo e cidade. (CURTIS, 2008)

Na Cidade-jardim ${ }^{10}$, de Ebenezer Howard, composta por núcleos de tamanhos definidos e envoltos por áreas verdes, as propostas de pequenas comunidades limitadas mostravam a preocupação com a higiene e o progresso (CHOAY, 2007, p. 220). Ainda, segundo Frampton (2008, p. 47), "a Cidade-jardim complementava as tentativas de melhorar, mediante a reforma social, as condições de vida e trabalho do proletariado industrial", mostrando a recorrente preocupação e pretensão de uma mudança social realizada através de um projeto de cidade. Em busca de um projeto de cidade que representasse uma totalidade cultural almejada determinou-se uma forma bem circunscrita e de limites precisos e de tamanho modesto. "Assim a população é ao mesmo tempo descentralizada, dispersada por uma multiplicidade de pontos e, em cada um deles, reagrupada de modo mais denso" (CHOAY, 2007, p. 13).

Na Cidade-Jardim a expansão da cidade se daria pela construção de outras cidades (Figura 16: Diagrama n.7 - conjunto de seis CidadesJardins menores e uma maior): "Os esquemas mostram uma rede de sete cidades interligadas pela ferrovia, sendo seis cidades menores periféricas (com 32 mil habitantes) e uma central chamada de Cidade Social (com $5^{8}$ mil habitantes). Esta cidade centralizaria um número de atividades maior do que as demais" (TREVISAN, 2003, p. 66).

${ }^{9}$ Tom Gunning cita Wolfgang Schivelbusch, "The Railway Journey: Trains and Travel in the Nineteenth Century", Nova York: Urizen Books, 1979, páginas 180-88.

${ }^{10}$ Conforme foi apresentada por Ebenezer Howard em 1898, combinava a disseminação urbana com uma colonização rural e um governo descentralizado. Howard postulava o apoio dos sindicatos no financiamento das habitações, a propriedade cooperativa da terra, o planejamento global e uma reforma moderada. Fixou o tamanho ideal da cidade jardim em 32.000 habitantes, tendo, além disso, seu crescimento restringido por um cinturão verde que a isolava, cada cidade deveria ser regionalmente localizada como núcleo satélite de uma cidade grande e ligada a ela por trem.

(FRAMPTON, 2008, p. 47) 


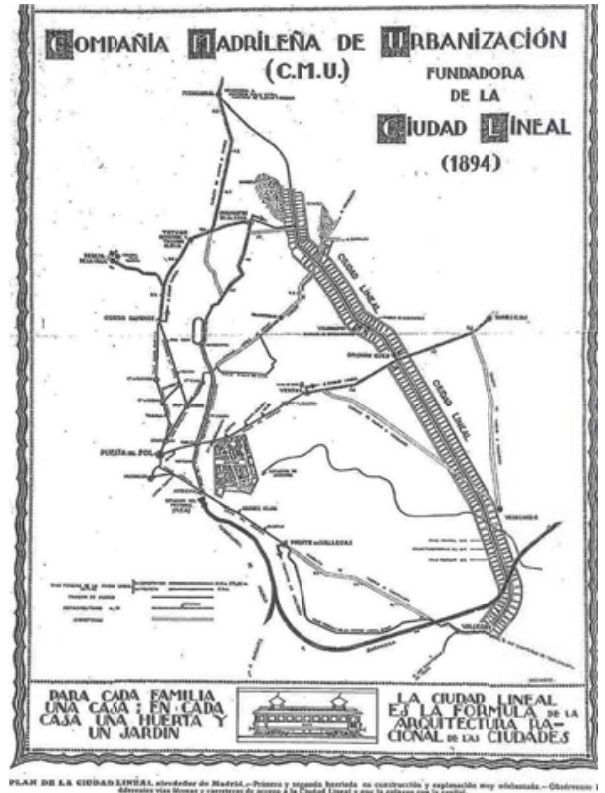

Figura 15: Plano da Cidade Linear, arredores de Madri (1894). Fonte: http://web.tiscali.it/icaria/urbanistica/utopie/soria.htm, acesso em 14.06.2013.

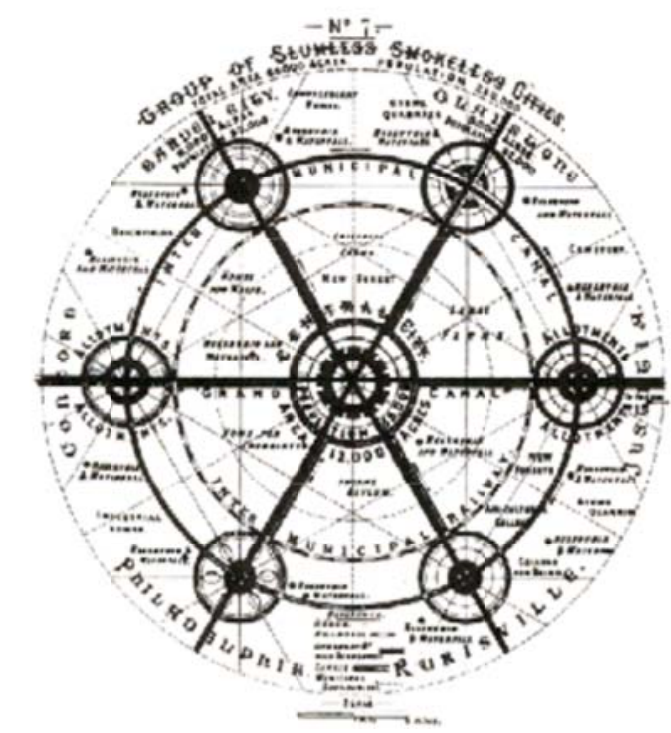

Figura 16: Diagrama n.7 - conjunto de seis Cidades-Jardins menores e uma maior ao centro, interligadas pela ferrovia e separadas pelo Cinturão Verde. (fonte: Beevers, 1988, p.138 apud Trevisan, 2003, p. 66)

Alguns dos princípios da Cidade-jardim, que defendia comunidades de tamanho gerenciável, nas quais as esferas urbanas e rurais poderiam ser unidas foram utilizados por Tony Garnier para lançar suas propostas para a Cidade Industrial entre 1901 e 1917, na qual a presença de áreas verdes é também uma premissa. Em sua primeira versão, exposta em 1904, apresentava uma concepção moderna e bastante detalhada de uma cidade socialista, sem muros ou propriedade privada, uma cidade onde todas as áreas não construídas eram parques públicos. Na área construída 
ficava estabelecida uma tipologia variada de moradias, segundo padrões de uso de luz e ventilação, criando códigos e padrões combinatórios articulados por uma circulação hierárquica (FRAMPTON, 2008, p. 119). Garnier sustentava que "o solo da cidade, considerado como um todo é como um grande parque, sem qualquer cerca delimitando as várias partes" (CURTIS, 2008, p. 244).

Na Cidade Industrial (Figura 17), a estrada de ferro seria utilizada para interligar as diferentes zonas (industrial, residencial e comercial) da cidade, acarretando numa concepção setorizada de espaços e funções na cidade. $\mathrm{O}$ zoneamento foi empregado para segregar a indústria da casa, $\mathrm{e}$ as ferrovias foram usadas para ligar os dois ao comércio. A hierarquia das partes também era determinada e reforçada pelo uso de eixos e esplanadas (CURTIS, 2008, p. 244).

Como projeto revolucionário de uma cidade, a Cidade Industrial exerceu forte influência nas concepções urbanísticas posteriores, notadamente em Le Corbusier, e Choay (2007, p. 164) destaca que o Garnier desempenhou um papel fundamental dentro da gênese da arquitetura moderna e do urbanismo.

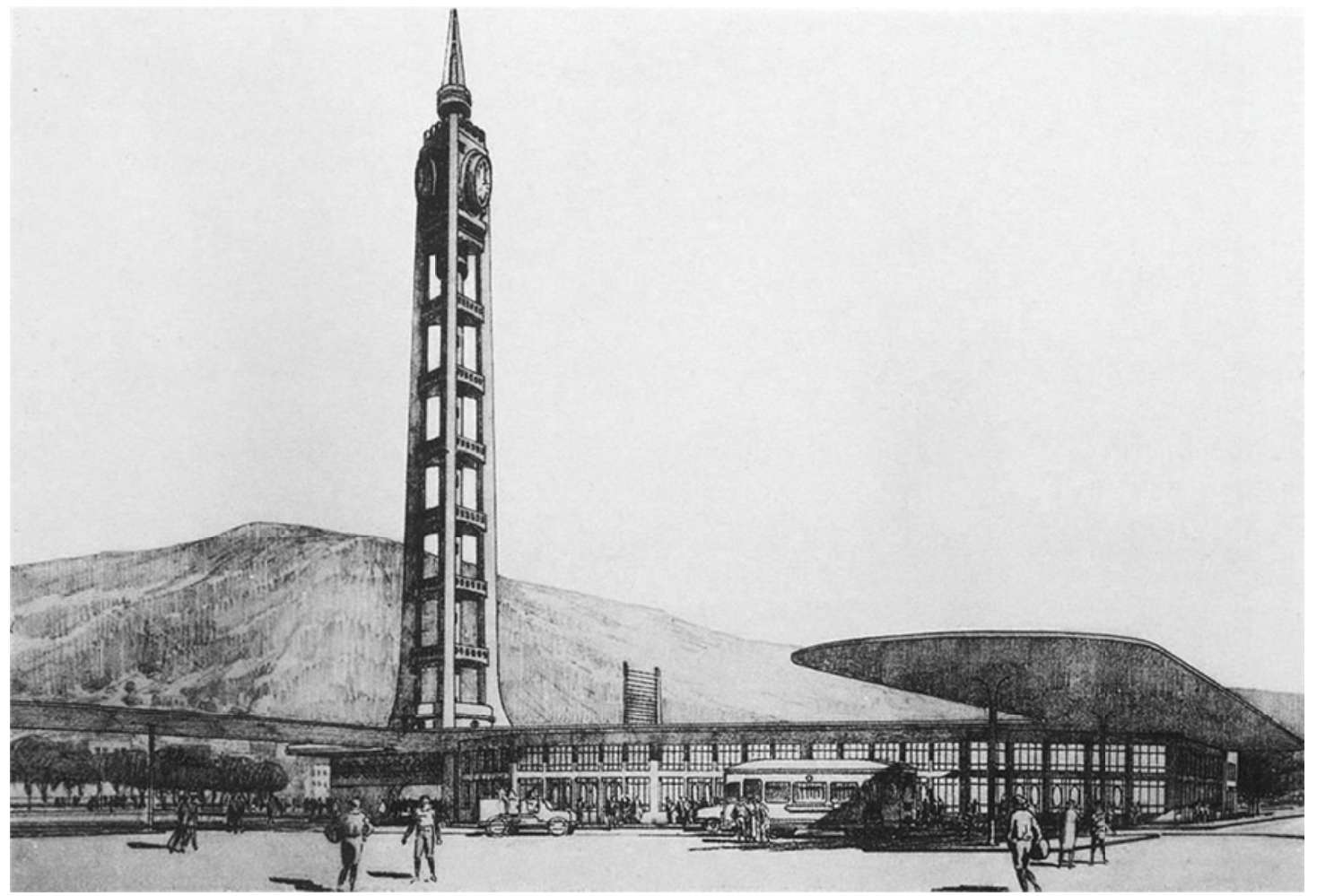

Figura 17: Tony Garnier, "Citè Industrielle" (1901-1917), estação ferroviária. Fonte: franksvensson.blogspot.com.br, acesso em 14.06.2013. 
O ideário da cidade como uma máquina que deveria ser capaz de organizar as transformações e a vida nas cidades se vê refletido nessas teorias urbanas e nos projetos de cidades. Françoise Choay defende que é possível distinguir dois "modelos" de "projeções espaciais, de imagens da cidade futura", e evidencia que há nesses modelos um caráter reprodutível e que "não são estruturas abstratas, mas, pelo contrário, imagens monolíticas, indissociáveis da soma de seus detalhes" (CHOAY, 2007, p. 7), e indica algumas razões para isso:

O que é expressão de desordem chama sua antítese, a ordem. Assim veremos opor-se, a essa pseudodesordem da cidade industrial, propostas de ordenamentos urbanos livremente construídas por uma reflexão que se desdobra no imaginário. Por não poder dar uma forma prática ao questionamento da sociedade, a reflexão situa-se na dimensão da utopia; orienta-se nela segundo as duas direções fundamentais do tempo, o passado e o futuro, para tomar as formas da nostalgia ou do progressismo. (CHOAY, 2007, p. 7)

Ambos os "modelos", nomeados por Choay de "progressistas" e "culturalistas", trabalham com uma tentativa de criar padrões de cidades com o foco no indivíduo, mas a maneira como este é tratado e o seu lugar na cidade é abordado de maneira bastante distinta. No "modelo progressista", segundo Choay (2007, p. 9), concebe-se uma estrutura racional e funcional que utiliza o homem como um indivíduo tipo do qual se procura definir necessidades tipo determinadas cientificamente. A orientação é o progresso e este se alicerça no desenvolvimento industrial e na ciência.

O espaço do modelo progressista é amplamente aberto, rompido por vazios e verdes. Essa é a exigência da higiene. (...) O espaço urbano é traçado conforme uma análise das funções humanas. Uma classificação rigorosa instala em locais distintos o hábitat, o trabalho, a cultura e o lazer. (...) A cidade progressista recusa qualquer herança artística do passado, para submeter-se exclusivamente às leis de uma geometria natural. (CHOAY, 2007, p. 9)

Já o modelo culturalista ou nostálgico, presente nas obras de Ruskin e Morris e ainda em Ebenezer Howard, parte não do indivíduo, mas do agrupamento humano no qual cada indivíduo mantém o seu papel original. "É em grande parte o desenvolvimento dos estudos históricos e da arqueologia, nascida com o romantismo, que fornecem a imagem nostálgica do que, em termos hegelianos, pode ser chamado a bela totalidade' perdida" (CHOAY, 2007, p. 11). Segundo a autora, esse modelo nega o geometrismo e preconiza a irregularidade e a assimetria, propõe cidades que se fecham na própria história, não havendo lugar para o progresso da indústria, por exemplo.

Os dois "modelos" observados por Choay, no entanto, não formam ideologias estanques e em alguns autores podem até assumir aspectos contagiados de uma ou outra teoria. O que é importante frisar é a 
existência de modelos que não assumiam a cidade como um problema ou encaravam-na como um processo contínuo, mas buscavam pensá-la como um objeto reprodutível, em busca de uma totalidade. A consequência disso é que, de acordo com Choay (2007, p. 14), "a cidade é extraída da temporalidade concreta e torna-se no sentido etimológico, utópica, quer dizer, de lugar nenhum".

A arquitetura que acompanha o projeto de modernização urbana busca a criação de uma imagem de cidade, favorecendo uma certa parcela da população e criando artifícios de hierarquização de espaços. Mas ainda não era capaz de resolver o dilema colocado pela sociedade industrial e revelava a dificuldade de adaptação ao ambiente urbano moderno, que configurava uma nova ordem, entre o público e o privado, entre as classes sociais, num novo espaço segregado pelo acesso à cidade e aos bens de consumo e informações. Destaca-se nesse sentido, o exemplo de Paris e a reforma urbana empreendida por Haussmann, entre $185^{2}$ e 1870, que incentivava a criação de grandes bulevares rasgando o tecido urbano ainda formado por vielas estreitas, evitando as aglomerações, em favor da circulação, higienização e organização do espaço urbano.

\footnotetext{
Uma nova ordem é criada, segundo o processo tradicional da adaptação da cidade à sociedade que habita nela. Nesse sentido, Haussmann, no desejo de adaptar Paris às exigências econômicas e sociais do Segundo Império, faz uma obra realista. E o trabalho que se realiza, se prejudica a classe operária, choca os estetas passadistas, incomoda os pequenos burgueses expropriados, contraria os hábitos, é, em compensação, a solução mais imediatamente favorável aos capitães de indústria e aos financistas que constituem então um dos elementos mais ativos da sociedade. (CHOAY, 2007, p. 4)
}

Segundo Jorge Bassani em "As linguagens artísticas e a cidade: cultura urbana do século XX" (2003, p. 40), as tentativas de organizar a paisagem da cidade pela hierarquia, setorização, valorização e criação de monumentos e perspectivas visuais visavam a uma nova imagem moderna para as cidades, mas a tornaram um "objeto em eterna construção, em processo, numa justaposição de coisas e acontecimentos".

No período de instabilidade que correspondeu à virada do século, se percebe a incapacidade de escolher entre uma herança cultural do século XIX, o repúdio do ambiente industrial ou as perspectivas da era da máquina e da indústria. A reconfiguração do ambiente urbano demandou colocar em prática ideias, conceitos e ideologias em busca de soluções urbanísticas, incentivadas, na primeira metade do século XX, pela urgente reconstrução demandada pelas duas grandes guerras mundiais (1914-1918 e 1939-1945) que acabaram por deixar o campo aberto para essas experimentações.

O ideário da máquina e a glorificação das tecnologias e da velocidade percorreram os manifestos das vanguardas da arquitetura, mas a 
exaltação da industrialização e sua crítica permeiam a discussão acerca do lugar que a máquina, o automóvel e a indústria deveriam ocupar na cidade e na vida de seus habitantes. A distribuição espacial das funções na cidade, a circulação e a questão da moradia acompanhavam o discurso que a arquitetura seria responsável por pensar e organizar a estrutura social, identificando muitas vezes o Movimento Moderno com uma visão totalizante, pela racionalização de processos e pesquisas de funções básicas dos espaços e necessidades mínimas do indivíduo.

A declaração de La Sarraz no primeiro Congresso Internacional de Arquitetura Moderna - CIAM, em 1928, enfatizava a arquitetura como construção e declarava que esta dependia da "adoção universal de métodos racionais de produção, (...) com o intuito de aumentar a produção de casas e deixar para trás os métodos de uma era artesanal" (FRAMPTON, 2008, p. 328). As primeiras conferências do CIAM, tidas como as mais doutrinárias, de tendências socialistas, voltaram-se para os problemas dos padrões mínimos de vida e da habitação. A participação de Le Corbusier nos CIAM e o contato com os arquitetos russos foram cruciais no que diz respeito à inserção de normas industrializadas e padrões mais econômicos de moradia.

A séria crise habitacional nos anos posteriores à Primeira Guerra Mundial acabou por favorecer propostas e hipóteses generalizadas para solucionar os problemas habitacionais em grande escala. Na Rússia, após várias tentativas de criação de uma técnica e estéticas racionalistas voltadas para a coletividade, coloca-se a busca por protótipos e tipologias para moradias comunitárias, unidades sociais, distribuição e circulação, que levou o governo a estabelecer grupos de pesquisa para standardização da moradia (FRAMPTON, 2008, p. 209). Essas pesquisas inspiraram o "Immeuble-Villa", de Le Corbusier, "uma célula-base de moradias de grande altura e densidade habitacional" (FRAMPTON, 2008, p. 186), que representava as pesquisas em busca de uma casa moderna:

Nosso mundo exterior transformou-se admiravelmente no seu aspecto e na sua utilização em consequência da máquina. Temos uma nova ótica e uma nova vida social, porém, não adaptamos a casa a isto. (CORBUSIER, 1977).

Algumas das formulações urbanísticas do Movimento Moderno são o resultado de processos e influências de diversas vertentes, entre elas, a Cidade Industrial e a Cidade- jardim. Frampton demonstra que Le Corbusier, um dos arquitetos mais ativos desse movimento, teve influências de vários movimentos artísticos, inclusive do "Arts and Crafts", do "Jugendstil" de Josef Hoffman, quando esteve em Viena, e de Tony Garnier, quando este trabalhava em seu projeto da Cidade Industrial: "as afinidades socialistas utópicas de Le Corbusier e sua suscetibilidade diante de uma abordagem tipológica - para não dizer clássica - da arquitetura certamente datam desse encontro" (FRAMPTON, 2008, p. 
180). Le Corbusier foi iniciado no concreto armado por Auguste Perret e foi seduzido pelas conquistas da moderna engenharia de produção no contato com o "Deutsche Werkbund", na Alemanha.

Essas diversas influências culminaram nos estudos de estrutura da "Maison Dom-Ino", das "Villes Pilotis" e sua rua elevada, assim como diversos outros estudos de cidades hipotéticas, como a "Ville Contemporaine pour trois million d'habitants" (Figura 18), de 1922. A "Ville Radieuse" (Figura 19), de 1931, que já concretiza o projeto de uma cidade mais aberta, elevada acima da superfície de um parque contínuo, facilitando o deslocamento. De acordo com Le Corbusier, "uma cidade feita para a velocidade é uma cidade destinada ao sucesso". Essa retórica também acompanhou a proposta do "Plan Voisin" para Paris em 1925.

A "Ville Radieuse" levou o conceito de cidade aberta da "Ville Comtemporaine" à sua conclusão lógica, e um corte típico através da cidade mostrava todas as estruturas erguidas bem acima do solo, inclusive as garagens e vias de acessio. Com a elevação de tudo sobre pilotis, a superfície do terreno teria se transformado num parque contínuo no qual o pedestre estaria livre para circular à vontade. (FRAMPTON, 2008, p. 218)

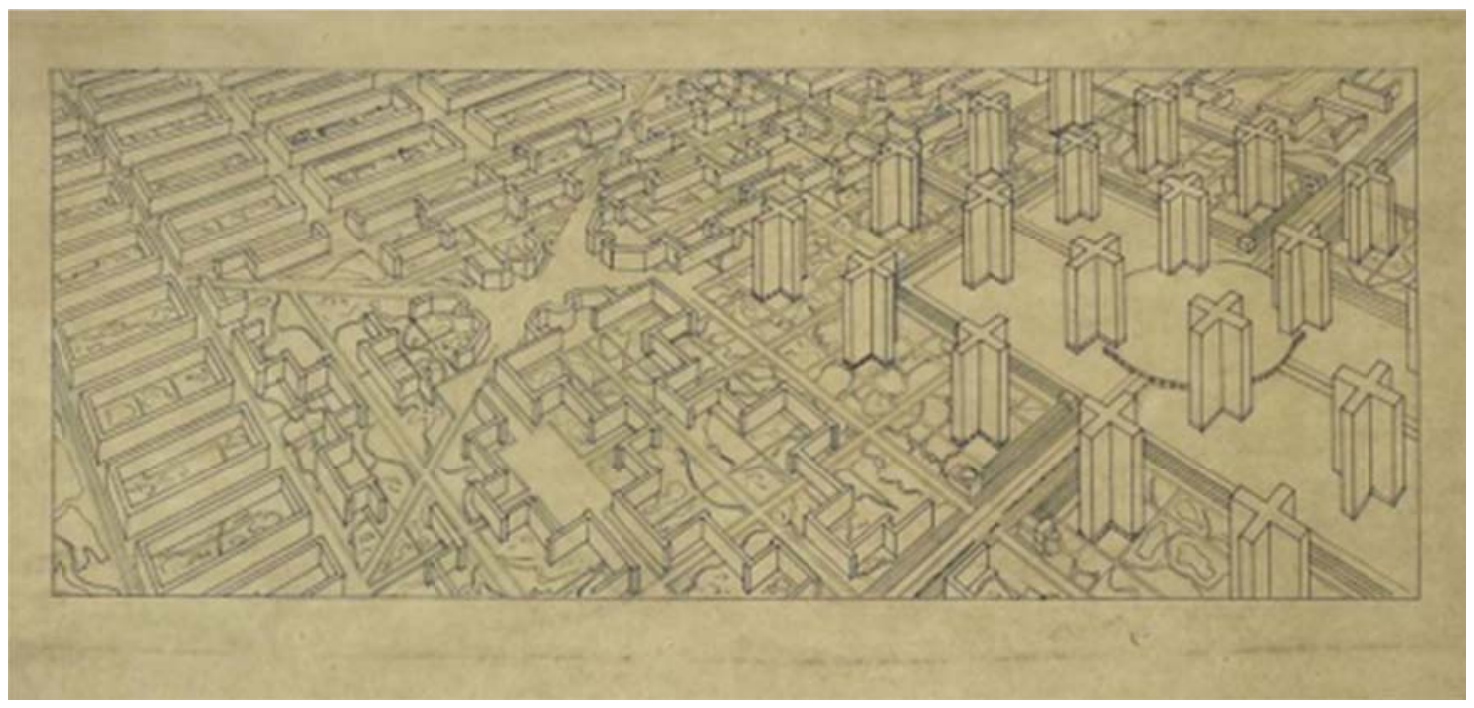

Figura 18: Le Corbusier, "Ville de 3 millions d'habitants". Fonte:

http://laboratoireurbanismeinsurrectionnel.blogspot.com.br, acesso em 23.06.2013. 


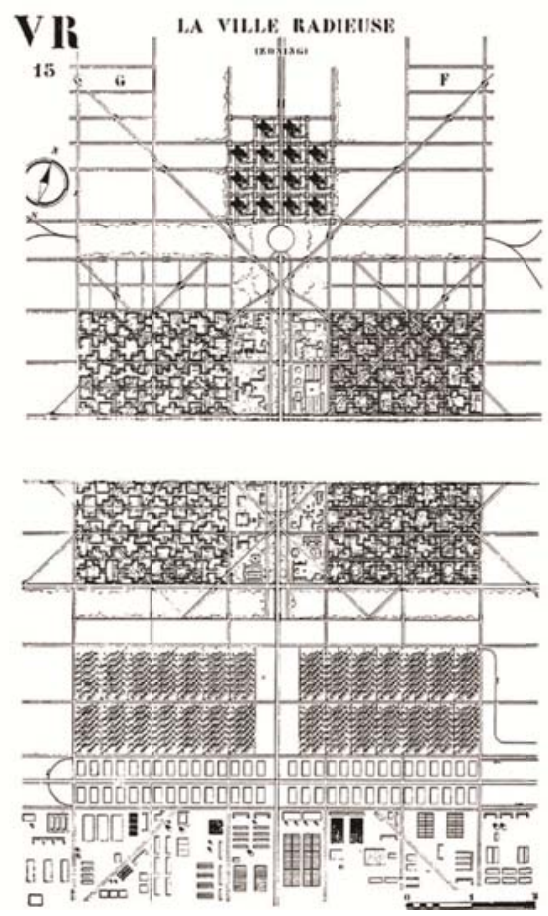

Figura 19: "Ville Radieuse", Le Corbusier, 1930. A planta mostra o zoneamento das funções da cidade (educação, negócios, residências) em faixas paralelas. Fonte: FRAMPTON, 2008, p. 217.

Já no CIAM IV, com o tema "A Cidade Funcional", com um foco maior no planejamento urbano, foi produzido um documento com 111 propostas sobre as condições das cidades e para correções dessas condições, agrupadas em categorias: moradia, lazer, trabalho, transportes e edifícios históricos. Destas, as primeiras quatro se estabelecem, segundo esse documento chamado de Carta de Atenas, as funções básicas do urbanismo moderno. $\mathrm{O}$ documento defendia um zoneamento funcional rígido, cinturões verdes, tipos padrão de moradia em blocos de apartamentos, entre outras diretrizes de planejamento e desenho urbano (LE CORBUSIER, 1993).

A transformação na paisagem das cidades pelas soluções de circulação e distribuição são priorizadas nos projetos modernistas através de grandes eixos de circulação e hierarquia viária. Com o novo paradligma da rua, tratada mais como espaço de circulação e menos como espaço de convivência, criou-se uma nova experiência que se identifica no fluxo de veículos na velocidade e nos percursos dos pedestres em espaços distintos. A sensação de movimento e fluidez também se encontra na própria arquitetura, em seus investimentos na habitação, que, por meio dos novos materiais e concepções de espaços, buscou representar a experiência dos corpos, da visão e da velocidade das máquinas. 
Há no Movimento Moderno uma característica defendida por Giedion em "Espaço, tempo e arquitetura" (apud HEYNEN, 1999, p. 30), apreendida das estruturas metálicas e o vidro das estações ferroviárias, pontes, conservatórios e salas de exposições do século XIX, que provocaram fortes reações, por representarem o prelúdio da arquitetura do futuro que seduziram os arquitetos modernos. Traziam a sensação de movimento a partir da experiência de uma interpenetração de espaços. Espaços exteriores e interiores que estão constantemente relacionados uns aos outros, de tal forma que, no final, não se pode fazer uma distinção clara entre os dois. Esse novo tipo de experiência espacial é fundamental no edifício moderno.

Esta imagem da interpenetração de espaços por meio de planos soltos, estrutura independente e transparências foi representada pela fotografia (Figura 2o), na qual o artista Moholy-Nagy descreve como a nova experiência espacial da arquitetura.

De duas fotografias sobrepostas (negativos) a ilusão surge de uma interpenetração espacial, que só a próxima geração pode ser capaz de experimentar na realidade como a arquitetura de vidro." (LÁSZLÓ MOHOLY-NAGY, 1929, apud HEYNEN, 1999)

${ }^{11}$ Tradução livre: "From two overlapping photographs (negatives) the illusion comes forth of a spatial interpenetration, which only the next generation might be able to experience in reality — as glass architecture". 


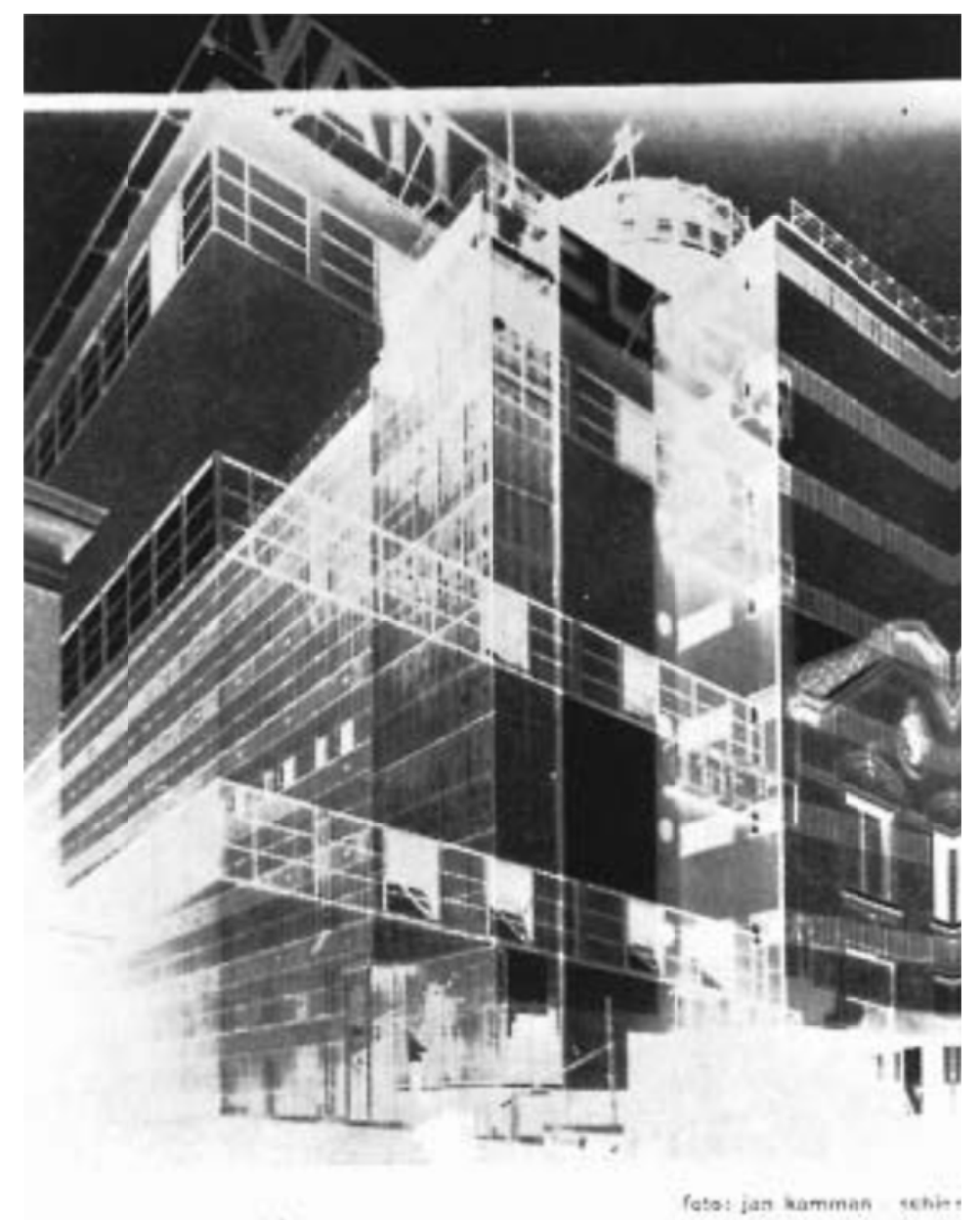

Figura 2o: “Architecture”, László Moholy-Nagy. Foto: Jan Kamman/Schiedam. Fonte HEYNEN, 1999.

Mario Pedrosa escreve, em "Espaço e arquitetura", em 1952, a sua impressão sobre a casa moderna, que esta procurava suscitar o estado de alma nos que penetrassem no espaço, e que o método para se conseguir este efeito é o movimento. E cita a frase de Geoffrey Scott de 1914:

Mas um movimento (o de avançar, numa nave, o de participar de dois planos no espaço como na arquitetura moderna era a realização do ideal pictórico da renascença, que entretanto se limitava a nos fazer ver o espaço em perspectiva linear. O movimento deve ter, porém, uma direção ou mais de uma dire:ção, servindo às finalidades da obra e do homem, que habita e sente o avesso do espaço (apud PEDROSA, 1981, p. 252)

Para ele, a casa moderna é também sensível ao mundo exterior, participa da paisagem, do clima. "Sua estrutura esquelética e sua planta aberta lhe dão afinidades com a árvore ou o avião.” E que a civilização já anseia por espaços maleáveis e ilimitados, como se esperasse uma nova dimensão, que, além das três euclidianas, poderia ser representada pelo movimento. 
Na percepção do arquiteto Solà-Morales (2003), a busca empreendida pelo Movimento Moderno foi por uma nova concepção de espaço que, mediante os avanços tecnológicos, transparências, vãos e novos instrumentos formais da abstração, tentou entender a evolução e a essência da arquitetura como criação de espaço. Essas concepções desenvolvidas pelas vanguardas contrapõem-se ao espaço tradicional definido volumetricamente, identificável e delimitado. No entanto, foi alvo de críticas principalmente por ter formatado espaços autônomos e com relações fracas e genéricas com o entorno.

Os preceitos contidos na Carta de Atenas apresentavam, muitas vezes, soluções de maneira seriada e generalizada, a partir de projetos totalizantes para resolver as principais questões colocadas pela nova forma de viver nas cidades. No entanto, seria errado afirmar que $o$ Movimento Moderno representava um conjunto hegemônico de pensamentos e obras, pois estava "inserido em um processo histórico impregnado de contínuas revisões e autocríticas, longe da ortodoxia mítica pretendida pela crítica mais radical" (MARQUES, 2002, p. 60). O autor chama a atenção para a diferença que existe entre a teoria e a prática e que desconsiderar essa diferença, assim como seus contextos, pode levar a simplificações e generalizações.

Mesmo em meio a críticas, foi após o período de guerras o momento em que a arquitetura moderna concretizou a maioria de suas obras, inspirou projetos de reconstrução de cidades e centros urbanos, e teve sua arquitetura tecnológica e seriada com formas simples aplicadas em grandes edifícios habitacionais, empresariais e institucionais mundo afora.

A fase pós-Segunda Guerra Mundial caracterizou-se por conflitos e desilusões por não reconhecimento da esterilidade abstrata da "cidade funcional" e pela aparente dificuldade em lidar com a situação urbana complexa no pós-guerra. $\mathrm{O}$ rompimento com as quatro categorias funcionalistas da Carta de Atenas foi proposto no CIAM IX, em 1953, quando a nova geração, liderada por Alison e Peter Smithson e Aldo van Eyck, apresenta um padrão mais complexo e mais sensível à necessidade de identidade (FRAMPTON, 2008, p. 330).

O homem pode identificar-se de imediato com seu próprio lar, mas não se identifica facilmente com a cidade em que este está situado. "Pertencer" é uma necessidade emocional básica - suas associações são da ordem mais simples. Do "pertencer" identidade - provém o sentido enriquecedor da urbanidade. A ruazinha estreita da favela funciona muito bem exatamente onde fracassa com frequência o redesenvolvimento espaçoso. (Relatório CIAM, 1953 apud FRAMPTON, 2008, p. 330)

O Movimento Moderno na arquitetura teve que lidar com conceitos de transitoriedade, fluidez e simultaneidade e com a materialização desses conceitos em forma de espaços funcionais. Também teve que incluir o 
novo homem, e sua nova maneira de habitar e pensar em sua contradição: entre o avanço do pensamento (razão e técnica) e o sentimento (angústia e transformação). Essas tendências contraditórias, produto da diferença entre pensamento e sentimento, por sua vez são o resultado dos enormes avanços tecnológicos e industriais do século XIX e XX.

Do lado da crítica ao modelo funcionalista do urbanismo moderno, Jacques (2012) cita os "situacionistas" ${ }^{12}$ e a psicogeografia e a deriva como forma de proporcionar o contato da arte com a vida cotidiana, que se daria no âmbito do espaço urbano através da experiência da cidade existente - através de novos procedimentos e práticas. A "construção de situações", conceito-chave que deu nome ao grupo, buscava realizar as experiências urbanas e utilizá-las como "observações ativas" e gerações de hipóteses sobre a cidade.

Enquanto os modernos acreditaram, em um primeiro momento, que a arquitetura e o urbanismo poderiam mudar a sociedade, os situacionistas estavam convictos de que a própria sociedade deveria mudar a arquitetura e o urbanismo. Enquanto os modernos chegaram a achar, como Le Corbusier, que a arquitetura poderia evitar a revolução - "Arquitetura ou revolução. Podemos evitar a revolução" -, os situacionistas, ao contrário, queriam provocar a revolução, e pretendiam usar a arquitetura e o ambiente urbano em geral para induzir à participação, para contribuir nessa revolução da vida cotidiana contra a alienação e a passividade da sociedade. (JACQUES, 2003)

Assim como os lugares marginais e obsoletos, fora da dinâmica urbana, aqueles lugares residuais que começam, segundo Solà-Morales (1995, p. 189) a ganhar a atenção, após os anos 1970, como uma visão diversa das grandes cidades: pois o "urbano parece visualizar-se de maneira primordial nesse tipo de paisagem". É o que o autor chama de Terrain Vague: "lugares estranhos ao sistema urbano, exteriores mentais no interior físico da cidade que aparecem como contraimagem da mesma, tanto no sentido de sua crítica como no sentido de sua possível alternativa $^{13 n}$ (idem, p. 188). Para o autor, isso acontece porque o sujeito metropolitano contemporâneo vive o paradoxo de construir sua

${ }^{12}$ A Internacional Situacionista é um grupo formado por Guy Debord, Raoul Vaneigem, Asger Jorn, Constant Nieuwenhuys e outros representantes, em 1957, para a elaboração do pensamento urbano situacionista. Editavam a revista IS: "Entre 1958 e 1969, 12 números da revista IS foram publicados e, se nos primeiros seis números (até 1961) as questões tratavam basicamente da arte passando para uma preocupação mais centrada no urbanismo, estas se deslocaram "naturalmente" em seguida para as esferas propriamente políticas, e sobretudo revolucionárias, culminando na determinante e ativa participação situacionista nos eventos de Maio de 1968 em Paris" (JACQUES, 2003).

${ }^{13}$ Tradução livre: "En definitiva, lugares extraños al sistema urbano, exteriores mentales en el interior físico de la ciudad que aparecen como contraimagen de la misma, tanto en el sentido de su crítica como en el sentido de su posible alternativa." 
experiência a partir da negatividade: "A presença do poder convida a escapar de sua presença totalizadora, a segurança chama a uma vida de risco, o conforto sedentário chama ao nomadismo desprotegido, a ordem urbana chama a indefinição do terrain vague" (idem, p. 188).

Os anos 1960-80 foram o período de revisão da produção modernista, por meio de intensas críticas e debates, que se dirigiram a um modernismo de ideias hegemônicas, de grandes paradigmas, propagados e zelados por seus seguidores. Segundo Marques (2002, p. 6o), "paradigmas densos de utopias dirigidas às massas; o pensamento marxista, a unificação de valores, a homogeneização de pensamento, (...)” foram o principal alvo das críticas e acabaram por promover uma mudança no foco: de uma narrativa de valores hegemônicos e universais para fragmentar-se na busca de sentido do lugar e da sua identidade, quando a rua, assim como o terrain vague, passa a ser reconhecida também pelas experiências (individuais ou coletivas) que proporciona.

\subsection{O cinema e a representação da rua}

Os avanços técnicos e a vida nas grandes cidades trouxeram também a curiosidade e a predisposição ao espetáculo. Realizado por aparatos elétricos ou por apresentações de variedades, circo, cabarés e música, a própria cidade oferecia o espetáculo de luzes e mecanismos em movimento.

\footnotetext{
O universo audiovisual de máquinas, fios elétricos, veículos de transporte, vitrinas, cartazes de propaganda, os aglomerados humanos, as luzes, os ruídos das grandes cidades compõem uma dinâmica que, vivida pela população urbana, transforma-se em espetáculo para a sensibilidade de alguns de seus contempladores ou protagonistas. Ao lado de automóveis, bondes e luzes das ruas, os interiores servem de palco para o desenvolvimento de novos espetáculos e atrações. Estes, na sua composição de movimento, luz, ruído e música, guardam uma correspondência com a agitação de lá de fora. No interior desta agitação, o cinema foi, durante certo tempo, uma novidade entre outras tantas, fazendo parte do conjunto de espetáculos que mobilizavam os mais diversos aparelhos e mecanismos, onde cérebro humano e eletricidade combinavam-se para mostrar algo novo a espectadores em busca de novas atrações. (XAVIER, 1978, p. 26)
}

A trajetória do cinema confunde-se com a das cidades desde o final do século XIX e a sua capacidade de registrá-las cria uma oportunidade de analisar a sua história. Não somente pelo registro da evolução visível dos espaços das cidades, mas também os hábitos, as linguagens, as críticas e as antecipações que o cinema foi capaz de realizar. $O$ cinema revolucionou a primeira metade do século $\mathrm{XX}$, materializando a história em busca de transformar sonho em realidade. Seja tomando partido e glorificando 
regimes autoritários, seja no pós-guerra, com o neorrealismo cinematográfico e as novas vanguardas nos anos $195^{\circ}$ e 1960, quando se coloca como instrumento de promoção de uma conscientização da realidade.

O nascimento do cinema percorreu uma epopeia técnica e científica, que durou quase todo um século, para a obtenção de uma ilusão de movimento satisfatória. Desenvolvidos a partir da fotografia e seus processos, entre 1826 e 1895, foram apresentados diversos mecanismos criados para dar movimento à imagem fotográfica ${ }^{14}$ (Figura 21 e Figura 22). Segundo Xavier em "Sétima arte: um culto moderno" (1978, p. 20), "existia uma base social para as experiências" e que esse investimento no mito da "reprodução das aparências" e da "duplicação do mundo" não era apenas uma questão de curiosidade: visto como um grande instrumento de exploração da curiosidade de um número cada vez maior de espectadores, essas invenções representavam um potencial econômico considerável.

A reação que a imagem cinematográfica podia produzir pode ser analisada, segundo Xavier (1978, p. 21), pela "valorização de um modo particular de figuração do real e a instauração desse tipo de 'olhar' como modelo de objetividade visual"; causado pela fidelidade da reprodução e seu efeito realista, que já era presente na fotografia, mas que se multiplica pela presença fundamental do movimento.

Durante a consolidação dos vários usos da técnica cinematográfica e suas maneiras distintas de dar um sentido e função social à nova prática, surge a oposição das tendências documentário/ficção e suas paternidades são atribuídas aos irmãos Lumière e a Meliès (XAVIER, 1978, p. 27). Enquanto Meliès buscava, por meio de truques, montagens e encenação, um cinema que encantava pela magia, os irmãos Lumière buscavam captar fatos do cotidiano com maior fidelidade.

A representação "objetiva" das aparências naturais alia-se ao truque de montagem e o realismo da figuração inscreve-se num espaço e num tempo fora das leis naturais. Tornam-se disponíveis a fidelidade da reprodução mecânica e a possibilidade do artifício pela manipulação do material filmado. (XAVIER, 1978, p. 27-28)

${ }^{14}$ Os aparelhos de ilusão de ótica constituíram um brinquedo doméstico de larga presença na Europa e nos Estados Unidos, e os grandes aparelhos constituíam um motivo de espetáculo capaz de atrair um enorme interesse popular. (XAVIER, 1978, p. 20) 


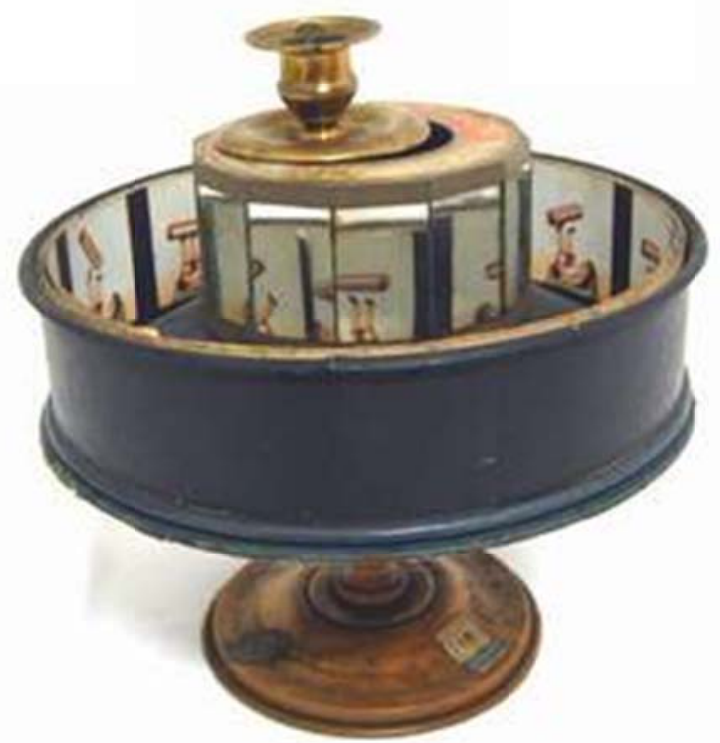

Figura 21: Praxinoscópio. Fonte: http://kinodinamico.com, acesso em 03.02.2014.

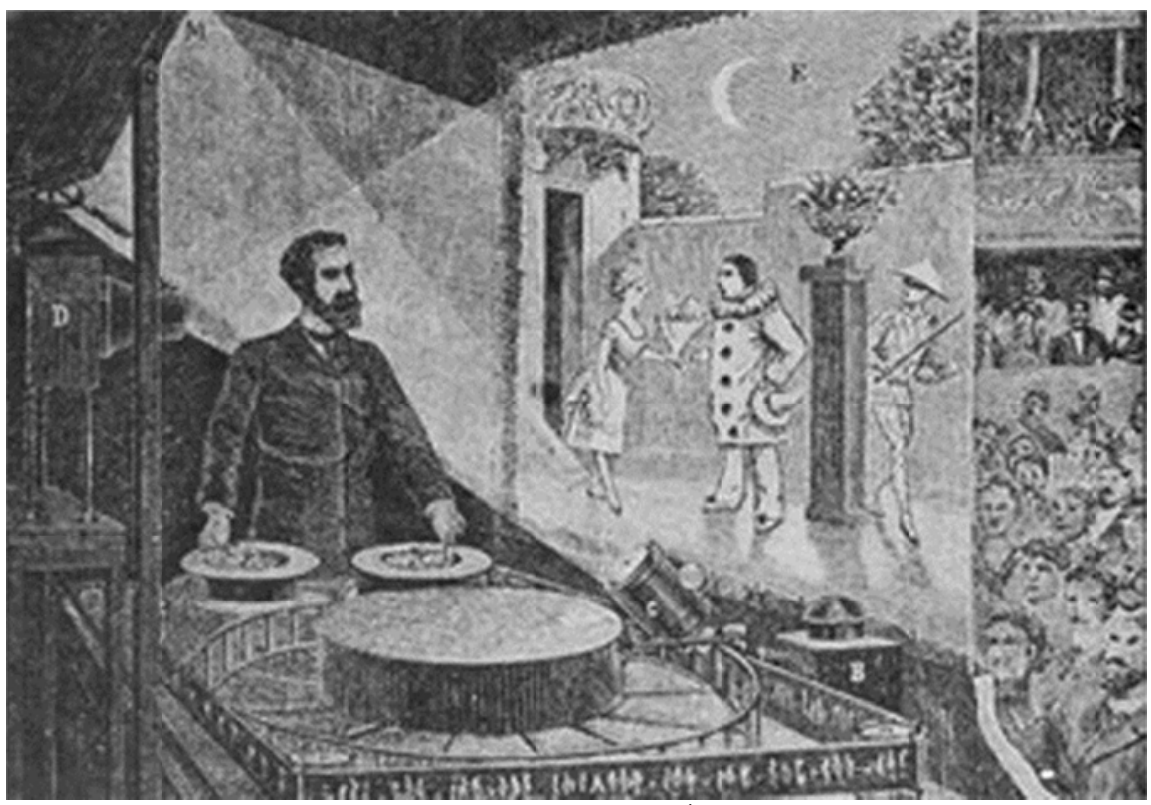

Figura 22: Ilustração apresenta a figura de Charles-Émile Reynaud (1844-1918) operando o dispositivo enquanto a multidão assiste à animação. Fonte: http://kinodinamico.com, acesso em 03.02.2014.

Mas é a partir dos anos 1920 e 1930 que o gênero documentário efetivamente se estabelece na Inglaterra, pela relação que faz ao documento como "prova" de algum fato ou evento (TEIXEIRA, 20o6, p. 253). Possui uma forte conotação representacional, comprobatória de um fato no tempo e espaço. Para Teixeira (2006, p. 253), "apli cada ao cinema por razões pragmáticas de mobilização de verbas, ela desde então 
disputou com a palavra ficção essa prerrogativa de representação da realidade e, consequentemente, da revelação da verdade".

Nos seus primeiros 20 anos, o cinema ficava, entretanto, envolvido por essa curiosidade e misturado à enorme quantidade de grandes atrações e novidades, sem ainda se afirmar com um código próprio, mas experimentando constantes transformações. Diz-se dessa primeira fase que seu objetivo era mais chamar a atenção do público do que a preocupação com a habilidade de contar histórias ${ }^{15}$. A intenção exibicionista, a "mostração", as "vistas animadas" constituíram uma maneira de introduzir a nova técnica ao público nas cidades ao redor do mundo.

As trucagens, as comédias, os filmes de perseguição, reconstituições de fatos e de narrativas clássicas demandavam uma produção e organização cada vez maior em busca de uma distribuição em larga escala. A busca se dava também pela qualidade narrativa e uma melhor compreensão do espectador, promovendo assim as melhorias técnicas:

As histórias eram impulsionadas por personagens dotados de vontades, mas os espectadores tinham dificuldades para visualizar motivações e sentimentos. Além disso, o público não conseguia entender claramente as relações espaciais e temporais entre os planos. O período de transição, entre 1907 e 1915, verá o desenvolvimento das técnicas de filmagem, atuação, iluminação, enquadramento e montagem, no sentido de tornar mais claras para o espectador as ações narrativas. (COSTA, 2006, p. 41)

Através da montagem, o cinema começa a ganhar uma nova estrutura narrativa: a atenção aos intervalos e às mudanças de plano configura a transição em direção a um novo cinema. A percepção descrita por Vertov de que "o material da arte do movimento é constituído não pelos movimentos em si, mas pelos intervalos existentes entre eles" (apud GERVAISEAU, 1996), vai modificar toda a estrutura narrativa cinematográfica. Nesse sentido, a contribuição do diretor americano D.W. Griffith é valiosa, ao experimentar diversos estilos de montagem, a utilização do contraplano e da continuidade de olhar (eyeline match), para criar a percepção da "mão do narrador, à medida que ele nos leva de um lugar para outro tecendo uma nova continuidade narrativa" (GUNNING apud COSTA, 2006, p. 47).

O cinema americano e o europeu começam a trilhar por estilos diferentes a partir desse período. A eclosão da guerra também modifica a linguagem cinematográfica e as inquietações colocadas pelas vanguardas artísticas contagiam o cinema, visto como nova tecnologia, mas também pela grande possibilidade que oferece às novas linguagens pela capacidade de reproduzir o movimento.

${ }^{15}$ Ver: COSTA, 2006, p. 24 
O movimento futurista na Itália, que desde 1909 defendia uma tomada de posição com relação passado/futuro, ao abolir a história, na tentativa de instaurar uma nova temporalidade, "substituindo a temporalidade dos processos reais e sua complexidade, por uma temporalidade ideal, composta de uma sucessão linear, onde justaposição e exterioridade marcariam a distinção entre fases 'voluntariamente' criadas" (XAVIER, 1978 , p. 33), percebe no cinema um aliado. Por meio de manifestos "corretores", este movimento publica, em 1916, um manifesto dedicado ao cinema: "ele inaugura uma tradição de protesto frente à presença, na prática cinematográfica, de algo que a modernidade deveria expulsar" (idem, pg. 33)

O cinematógrafo futurista que preparamos, deformação alegre do universo, síntese alógica e fugaz da vida mundial, será a melhor escola para a juventude: escola de alegria, de velocidade, de força, de temeridade e de heroísmo. O cinematógrafo futurista vai tornar mais aguda e desenvolver a sensibilidade, vai acelerar a imaginação criadora e dará à inteligência um prodigioso senso da simultaneidade $\mathrm{e}$ da onipresença ${ }^{16}$.

Xavier demonstra ao longo do texto o quanto a ideologia futurista produziu reflexos na abordagem da vanguarda francesa e nas reflexões teóricas/técnicas russas, próximo à Revolução de 17, quando Maiakovski instaura um "futurismo de esquerda". Embora dentro de um pensamento que caminha em direção totalmente distinta, traços futuristas (de Marinetti) são marcantes em algumas formulações contidas no primeiro manifesto do grupo de Dziga Vertov, redigido em 1919. O texto-programa do grupo de documentaristas, "NÓS" ${ }^{17}$, não deixa de apresentar, como traços importantes, o culto à velocidade, à precisão, à infalibilidade da máquina, compondo um elogio ao ritmo, à beleza dos processos químicos e mecânicos; sua argumentação conduz ao cinepoema, mostrador da "alma da máquina", do "homem elétrico perfeito" e da "poesia das alavancas". (XAVIER, 1978, p. 37)

A positividade do cinema estaria depositada na sua "modernidade", dentro de um pensamento que entendia esta modernidade como "esquecimento" e oposição à tradição, como ruptura radical com o passado. A nova arte das imagens, fruto de uma nova técnica, isenta de qualquer ingerência de uma tradição nela ausente, assumiria uma posição de extrema importância, pois em nenhum outro lugar estaria melhor concretizado o ideal de um presente sem memória, que olha exclusivamente o futuro. (XAVIER, 1978, p. 33)

${ }^{16}$ A partir da tradução do texto no livro: "Cinéma, Théorie, Lectures", Paris, editora Klincksiek, 1973, artigo "La cinematographie Futuriste”, p. 279. (apud XAVIER, 1978, p. 35)

${ }^{17} \mathrm{O}$ texto "NÓS" foi publicado pela primeira vez em 1922; utilizou-se a tradução francesa encontrada no livro de "Dziga Vertov: Articles, journaux, projets". (XAVIER, 1978, p. 37) 
O "Manifesto do Cinema-Olho", escrito pelo cineasta russo Dziga Vertov (1896 - 1954) em 1923, defende o "estudo preciso dlo movimento" como forma de obter o ritmo próprio da arte cinematográfica atrelada ao que o manifesto chama "poesia das máquinas", isto é, longe das imperfeições do olho humano (Figura 23). Sua obra-prima "O homem com a câmera de filmar" (1929) registra a vida das cidades russas, principalmente de Moscou, sob vários ângulos, ao longo de um dia todo, desde a manhã até a noite.

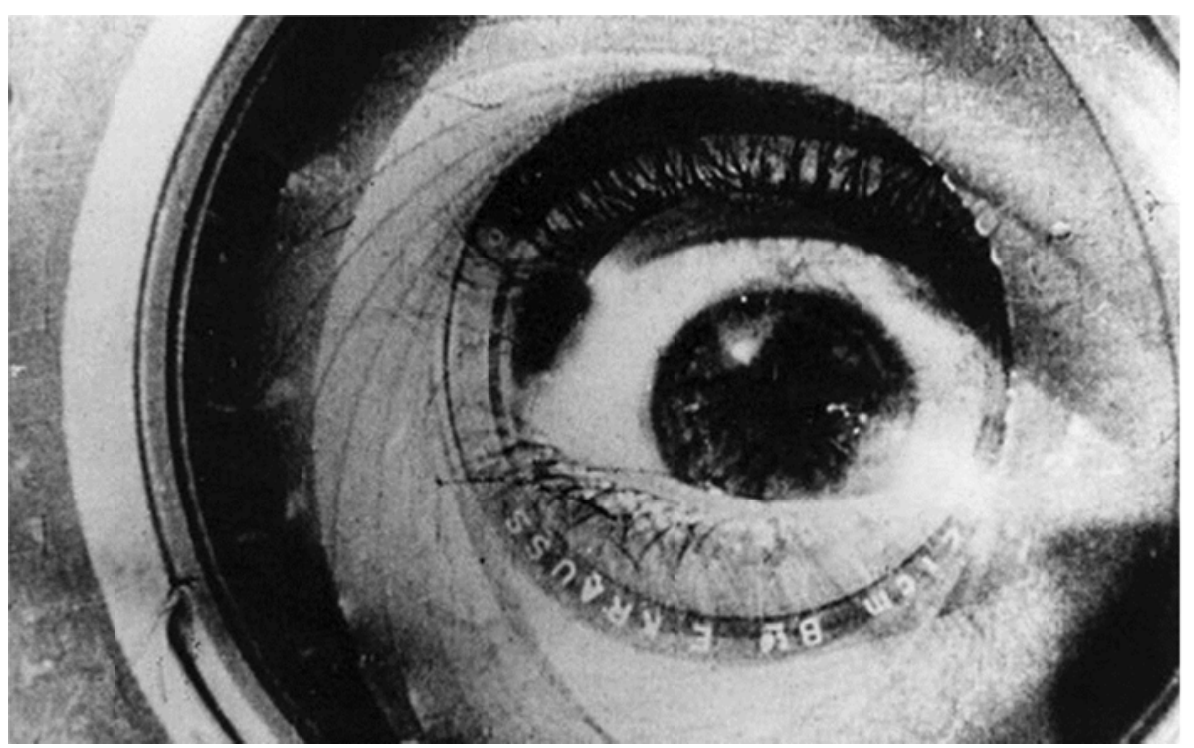

Figura 23: "Um homem com uma câmera de filmar" (Dziga Vertorv, 1929). Fonte: http://www.contracampo.com.br, acesso em 03.04.2014.

No entanto, pela proximidade que o movimento futurista construiu, na Itália, com o fascismo e a guerra, considerada como "a úmica higiene do mundo", as vanguardas francesas, as russas e mesmo a brasileira, procuravam afastar-se de qualquer ligação ou citação ao movimento. $\mathrm{O}$ mesmo poderia se comentar sobre o cinema alemão e sua fase expressionista, que produziu "O gabinete do Dr. Caligari" (Robert Wiene, 1920), e o diretor Fritz Lang, por exemplo. Sua estética misteriosa e sombria é vista como "uma das fontes preparadoras do nazismo" (CÁNEPA, 2006, p. 83). Reputação, segundo a autora, bastante ambígua, já que havia outros movimentos em jogo. Cánepa cita entre eles a tendência da Nova Objetividade e de uma "Revolução Conservadora":

Nas artes esta tendência se traduziu em obras que se interessavam pelas questões tecnológicas e, ao mesmo tempo, faziam elogio à cultura nacional alemã. $\mathrm{O}$ apoio de diversos artistas a essas ideias (não raro o próprio Fritz Lang é apontado como um deles, especialmente por seu filme "Metropolis", de 1927) acabou por se tornar maldito quando, a partir da crise de 1929, tais ideias se tornaram cada vez mais populares e, em pouco tempo, serviriam como uma das principaiis bases ideológicas do partido nazista. (CÁNEPA, 20o6, p. 83) 
Mesmo que em muitos manifestos as ideologias que inauguram as formulações teóricas sobre cinema sejam distintas, a relação com a máquina e a velocidade são muito semelhantes, assim como a busca por uma nova temporalidade.

A montagem no cinema é o que estrutura o tempo, o ritmo e a continuidade na narração. Vertov percebia a montagem como uma maneira formal de construção, métrica e complexa. Seu conceito de intervalo se dá pela "correlação entre planos, ângulos, movimentos, luz, velocidades - entre os elementos cinematográficos com os quais se reconstrói o mundo visual de modo significativo" (SARAIVA, 2006, p. 138). Já o seu contemporâneo, o diretor Eisenstein, com seu filme "Outubro", de 1927, comemorativo dos 10 anos da Revolução de 17, rejeitava a ideia de montagem como "justaposição ritmada de segmentos estanques" e defendia: "Do meu ponto de vista, a montagem não é um pensamento composto de partes que se sucedem, e sim um pensamento que nasce do choque de duas partes, uma independente da outra (...) que explodem em um conceito novo" (SARAIVA, 2006, p. 132).

A montagem soviética gerou influência no cinema do mundo todo, em sucessivas gerações, "a polêmica em torno da montagem soviética estava em pauta" (SARAIVA, 2006, p. 139). Essas experiências de montagem, a relação do cinema com a política, as evoluções tecnológicas vão revolucionar o cinema e serão continuamente retomadas pelos cineastas em diversas fases.

Todos os cineastas que, nos anos 1960, trabalharam numa chave que associava estética e política tinham na escola soviética uma referência incontornável. No Brasil - citando um momento seminal - basta assistirmos à cena do massacre do Monte Santo, em "Deus e o diabo na terra do sol" (Glauber Rocha, 1964), para percebermos a presença de Eisenstein. (SARAIVA, 2006, p. 139)

Este cinema "mudo", porém de uma força simbólica extraordinária, irá influenciar o novo cinema do pós-guerra e uma referência teórica e estética constante. Mesmo com a sonorização dos filmes, a montagem nunca mais perderá a atenção dos realizadores pela força que concede à narrativa. A inserção do som virá, no entanto, influenciar significativamente o cinema documentário ao dar voz às personagens, quando estas são chamadas a expressar-se como indivíduo/cidadão.

O cinema sonoro ganha força a partir do final da década de 1920, mas, ao que parece, o som no cinema fora inventado logo no início. No entanto, não chamou atenção naquele momento, pois os investidores não viam motivo em investir pesadas somas no aperfeiçoamento do aparelho de sincronização do som/imagem, já que o negócio já dava lucros satisfatórios. Para as grandes companhias não parecia interessante substituir todo o equipamento. Múrias descreve este contexto: 
O cinema sonoro iria obrigá-las a substituir milhares de aparelhagens de projeção que tinham espalhadas por toda a América, iria obrigá-las a insonorizar os estúdios, modificando radicalmente os processos de filmagem e impondo a utilização maciça da luz elétrica para iluminação fotográfica - impor-lhes-ia a substituição de muitas das suas vedetas, artistões de pacotilha que só mudos se suportavam. (MÚRIAS, 1962, p. 201).

Não somente na América, mas na Rússia, por exemplo, o pensamento era o mesmo. Mas, em 1926, o estúdio Warner, à beira da falência, resolve investir no aparelho Vitaphone, criado pela Bell Telephone Company, e produz em 1927 "The Singer Jazz", revolucionando o mercado cinematográfico (MÚRIAS, 1962, p. 202). O cinema sonoro ganha, nos Estados Unidos, a euforia do grande público, e com os westerns invade as salas de cinema ao redor do mundo, provocando um verdadeiro modismo de grande capacidade imagética.

O grande cinema desses anos 1930 era importado de Hollywood; na Califórnia estavase em pleno apogeu do cinedrama. Nem os russos nem os franceses, nem os italianos, nem os ingleses se salientaram por um conjunto filmográfico: impuseram, é certo, alguns nomes, algumas obras; o cinema era americano - e sê-lo-ia quase até ao fim da Segunda Grande Guerra. (MÚRIAS, 1962, p. 206)

Ao final da Segunda Guerra, a Europa estava em ruínas e a necessidade de intensificar as relações com a realidade das ruas se impôs como maneira de realizar a tarefa de se reerguer moralmente. Na Itália, Roberto Rossellini produziu "Roma cidade aberta" em 1945 (Figura 24), considerado o marco inicial ${ }^{18}$ do neorrealismo italiano, onde desnuda a cenografia cinematográfica dos estúdios e introduz a realidade (e seu "horror") utilizando a câmera como instrumento de investigação e reflexão, numa perspectiva filosófica que se soma à técnica de filmar o "real no seu fluir", como faziam Vertov e Flaherty. (PIERRE, 1996, p. 151).

${ }^{18}$ Existem divergências a respeito dessa atribuição. Para mais informações, ver: FABRIS, Neo-realismo italiano, 2006. 


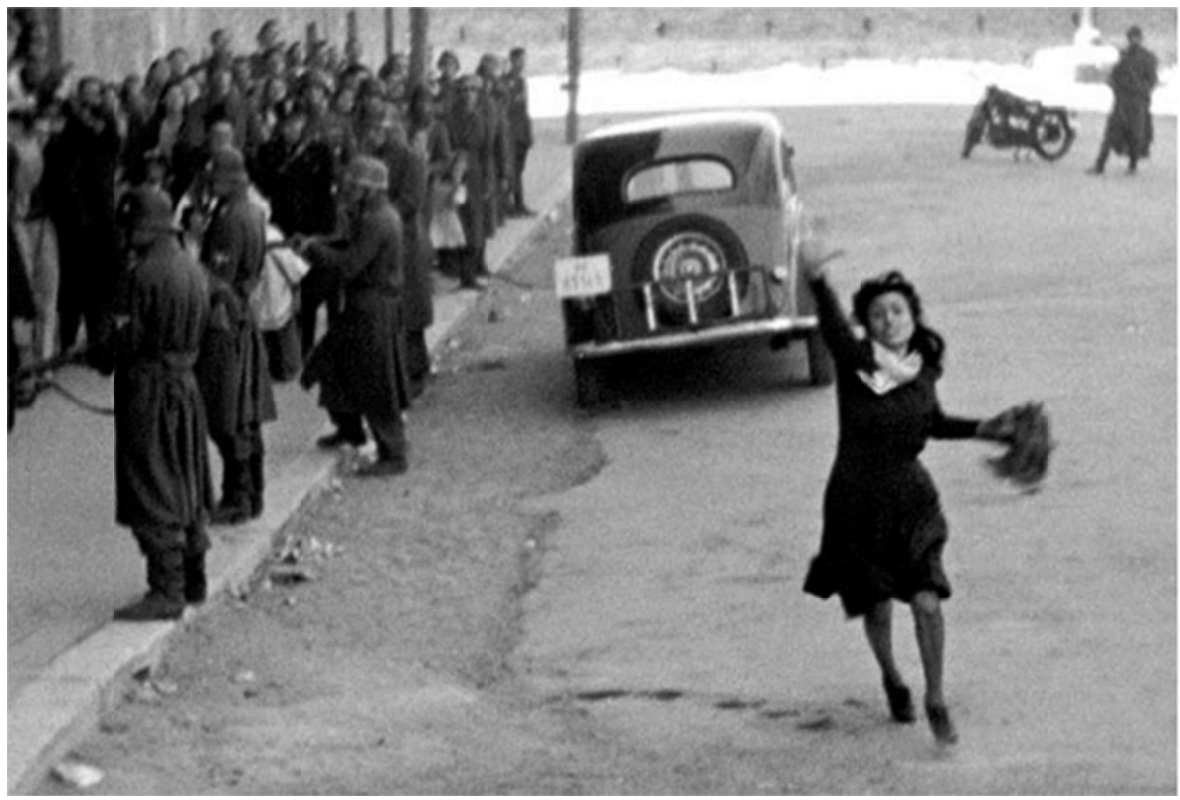

Figura 24: "Roma, cidade aberta", Roberto Rossellini, 1945. Fonte: still do filme, http://worldscinema.org, acesso em 03.02.2014.

Segundo Fabris (2011, p. 211), "nesse período levar as câmeras às ruas significava começar a questionar as normas do regime fascista, que propunha uma representação irreal do país". A busca pela realidade era somada à espontaneidade da rua também no sentido do roteiro, que não era fechado e possibilitava responder aos estímulos do ambiente ou de uma circunstância. Dessa maneira se poderia "devolver a contemporaneidade aos acontecimentos” (idem, p. 212).

Segundo Zavattini, a representação da realidade deveria ser substituída pela própria realidade: dessa forma a câmera deixaria de lado um esquema já preestabelecido para movimentar-se de acordo com seu contato direto com a vida. Estava formulando, assim, suas teorias sobre o pedinamento (estar no encalço de alguém) do buco nel muro (buraco na parede) e da poetica del coinquilino (poética do vizinho), pelas quais era necessário sair às ruas para conhecer o próximo, interessando-se por qualquer momento de seu dia a dia. (FABRIS, 2006, p. 211)

A principal particularidade dessa manifestação no cinema italiano é o contraste entre dois meios sociais que dividem a mesma cena, tema que se impõe após 1945, com a miséria e os destroços da guerra. A atmosfera, a fotografia, a interpretação e a narrativa que unia uma vontade da nação que estava em busca de salvação caracterizaram seu conteúdo e forma, e comumente traziam uma emoção e um forte vigor dramático.

O documentário ganha força nas discussões ontológicas sobre o cinema na década de 1950, quando os cineastas resolvem deixar de lado os estúdios e levar suas câmeras para conhecer e retratar a realidade. As vanguardas, no entanto, procuravam muitas vezes produzir filmes artísticos e teatrais, os filmes "de arte", estabelecendo uma suposta divisão entre documentário e ficção. 
Por cima dos atributos e intenções que o configurariam como um gênero, a questão reivindicada pelo documentário era de cunho epistemológico, ou seja, uma questão de como conhecer, formar, educar com os meios postos à disposição pelo cinema, num momento em que o modelo ficcional nele se alastrava e destituía a realidade como referente. (TEIXEIRA, 2006, p. 254)

O principal debate que se estabelece a partir dessa suposta divisão é a relação com a verdade, ou com uma verdade estabelecida. "A verdade como revelação de algo imerso na espessura, opaca ou transparente, do mundo, e a que se tinha acesso, fosse por meio de uma parafernália de artifícios do cinema ficcional, fosse pela visão límpida e direta do cinema documental" (TEIXEIRA, 2006, p. 255)

Outra questão que se coloca, e tão complexa quanto a busca da "verdade", é a questão do tempo. Até um momento a temporalidade se dava por meio de uma passagem sucessiva e cronológica do tempo (passado - presente - futuro), porém, essa prerrogativa se altera para uma "concepção crônica do tempo, em que passado e presente se constituem mutuamente, de modo coextensivo e simultâneo" (TEIXEIRA, 2006, p. 255). Derivando aí também para duas perspectivas do documentário, o etnográfico e o da investigação ou reportagem. Assim, ou se mostram objetivamente as situações e personagens reais, ou subjetivamente as maneiras de ver dos personagens e seus problemas.

Ainda, para Teixeira (2006, p. 261), o documentário dito moderno, aquele que frutifica após a Segunda Guerra encontra uma realidade nua a partir da perda da inocência e ingenuidade a respeito do próprio poder destrutivo da humanidade e da racionalização exacerbada vista como causa da destruição. A linguagem encontra a voz, "portanto é do seu 'ser' que se fala". (TEIXEIRA, 2006, p. 261)

O cinema moderno, como o neorrealismo, a Nouvelle Vague e o cinéma-verité de Jean Rouch conectam-se nesse sentido com a busca documental por uma linguagem ética relacionada a este novo "ser" social. A realidade era dotada mutuamente de aspectos ordinários e extraordinários em quantidade suficiente para que documentário e ficção pudessem encontrar material imagético e sonoro para realizar o seu recorte narrativo.

A questão da sinceridade, muito mais que a da verdade que começara a ser minada com as simulações de narrativas, impôs-se de modo contundente desde os primeiros contatos dos cineastas com uma realidade em ruínas e suas demandas de reconstrução. (TEIXEIRA, 2006, p. 267)

Na França, "uma juventude tão reboliceira como a do vanguardismo, ventilou e discutiu as ideias, teorizou-as e foi erguendo um cinema novo" (MÚRIAS, 1962, p. 412). Philipe de Broca, Claude Chabrol, Eric Rohmer, Jean-Luc Godard, Allan Resnais, Jacques Rivette, François Truffaut, entre dezenas de outros realizadores começam a filmar, aproveitando o clima 
propenso à renovação que culminaria em maio de 1968. "O movimento cinematográfico levou às telas expectativas e frustrações de uma geração de jovens amadurecidos na Guerra Fria, numa Europa pós-guerra sem inocência, massificada e hiperpovoada de imagens do cinema, da publicidade e da recém-consolidada televisão" (MANEVY, 2006, p. 222). Representante na Nouvelle Vague, o filme "Jules et Jim", de 1962 (Figura 25), dirigido por François Truffaut, mostra a relação de 3 jovens boêmios numa exuberante história sobre a liberdade, a lealdade, a coragem e o amor.

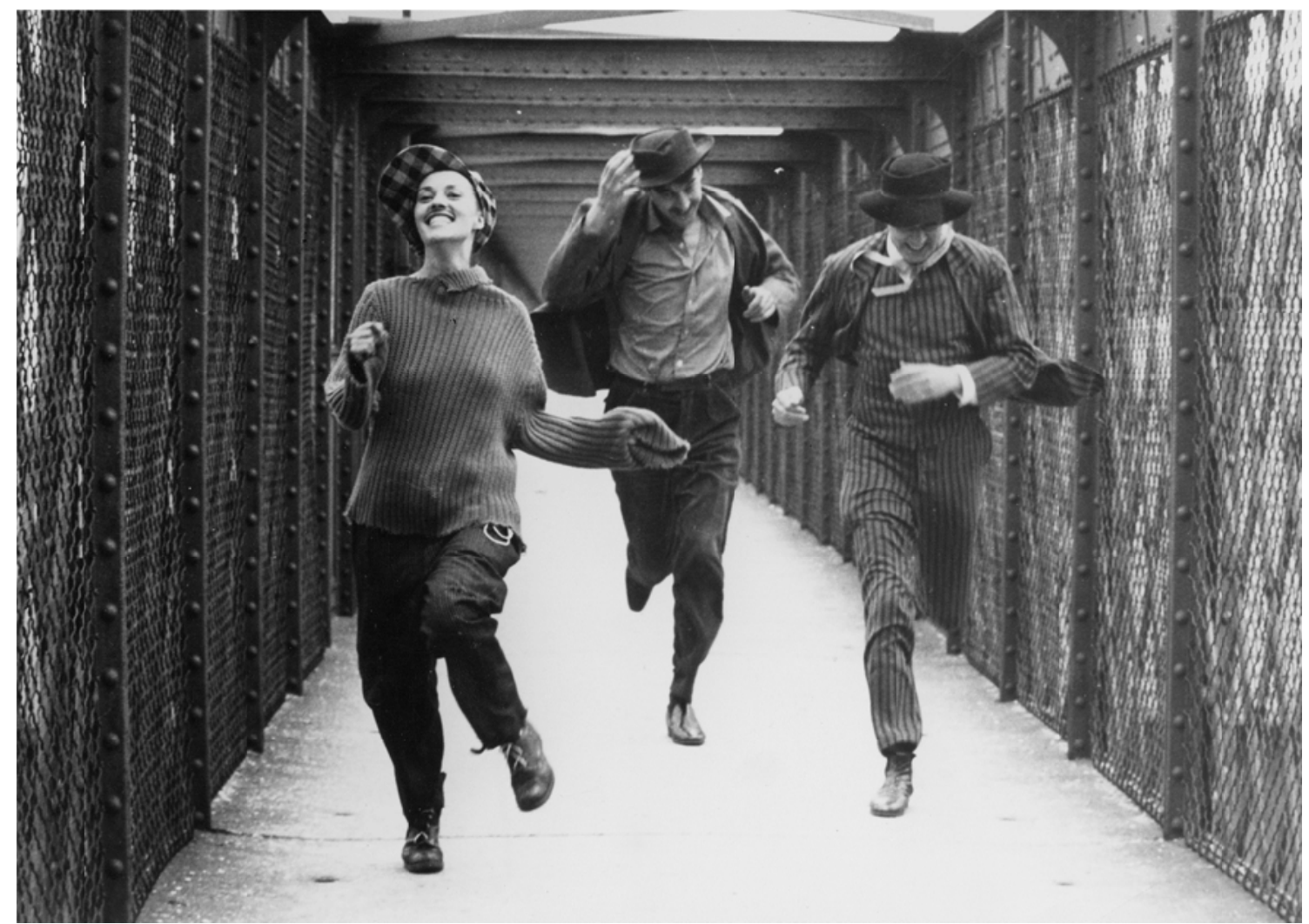

Figura 25: still do filme "Jules et Jim", Truffaut, 1962. Fonte: www.cinematheque.fr, acesso em 04.04.2014.

A Nouvelle Vague foi o primeiro movimento cinematográfico produzido com base em um interesse pela memória do cinema. Os filmes censurados ou perdidos durante a guerra foram resgatados e exibidos por Henri Langlois, cofundador da Cinemateca Francesa, o mais amplo acervo cinematográfico do mundo (MANEVY, 2006, p. 220-222). A figura de André Bazin, crítico e cineclubista, também se destaca neste cenário pela série de artigos que "são capítulos decisivos da teoria cinematográfica. Ler a fase crítica da Nouvelle Vague (1947 a 1959) é tão importante quanto ver os filmes (1959 a 1968)". (MANEVY, 2006, p. 222)

Para Manevy (2006), na formação intelectual da Nouvelle Vague, a paixão crítica pelo cinema americano clássico foi tão fundamental como o 
interesse pela literatura e pintura modernas e seus valores: a descontinuidade, a incorporação do acaso e da realidade documental, a valorização da montagem. Os artigos e críticas produzidas por André Bazin, o resgate dos filmes clássicos e das vanguardas do início do século em sessões promovidas pelos cineclubes e pela Cinemateca Francesa criaram uma geração de cinéfilos e cineastas com atitude crítica e vasto conhecimento da história do cinema. Assim, Manevy faz um breve resumo do que significou este movimento:

Laboratórios por excelência de uma estética do fragmento, da incorporação do acaso na filmagem, da polifonia narrativa e de uso de formas até então atribuídas ao documentário, às artes visuais, ao ensaio e à literatura, a Nouvelle Vague fez chegar ao cinema a sua juventude tardiamente, com um pé na maturidade, compondo uma observação autocrítica dos imaginários urbanos, antropologia radical oposta à vocação de "vulgaridade e comércio" do cinema e das mitologias da sociedade de consumo. (MANEVY, 2006, p. 221)

A década de 1960 constituiu o ponto culminante da expansão das cidades, em decorrência das grandes modificações nas relações econômicas após a Segunda Guerra Mundial. Grandes metrópoles com mais de 5 milhões de habitantes se expandem por todo planeta. Neste ambiente das grandes metrópoles o cinema segue reproduzindo a multiplicidade, dispersão e interação da sociedade e o ambiente urbano.

No Brasil, esses movimentos europeus do pós-guerra geraram um impacto na produção cinematográfica e intelectual que alterou os rumos do cinema em direção a uma produção genuína e singular, ao olhar para a própria realidade. A Nouvelle Vague em especial, como destaca Manevy:

Diversos críticos escreveram sobre o movimento francês no calor da hora, como Paulo Emilio, Alex Viany, Glauber Rocha e Walter Lima Jr. Mais tarde Ismail Xavier e Jean Claude Bernardet renovaram as formas de abordar o assunto e mostraram como o cinema moderno brasileiro partiu, em boa medida, da Nouvelle Vague, pra depois seguir caminho inteiramente próprio e independente. (MANEVY, 2006, p. 251)

As iniciativas e os movimentos realizados pelo cinema em um século possibilitam infinitos olhares e análises. A própria definição dos movimentos como a Nouvelle Vague, por exemplo, é divergente, dependendo do referencial que se adota, pois se trata de um movimento contínuo, com uma ou outra fase mais demarcada. A importância deste breve percurso pelo cinema é dar suporte à compreensão do que se produziu no Brasil e fazer um paralelo entre as linguagens e as buscas empreendidas pelo cinema brasileiro e estrangeiro, suas influências e características principais. 
Sendo assim, foi possível entender como o cinema foi tratado como ferramenta de modernidade, em função de sua filiação técnica e industrial e pelo dinamismo de sua imagem, em sintonia com as novas condições da experiência testemunhada na vivência cotidiana e nos fluxos da cidade. $O$ cinema percorreu um processo de legitimação a partir dos anos 1920 e ao longo do século XX, até que "passa a ser objeto de atenção do erudito e parte do corpus sacramentado da cultura dominante" (XAVIER, 1978, p. 14), ao deixar de ser apenas entretenimento para tornar-se a sétima arte.

Nas décadas de 1950 e 1960, após as duas Guerras Mundiais, realiza uma nova ruptura e se coloca como instrumento de promoção de uma conscientização da realidade em face ao quadro de conflitos sociais, ao ganhar a rua e fazê-la participar, não apenas como cenário, mas como local de investigação e reflexão.

Assim, buscou-se compreender a constante busca de renovação e angústia causada pelo descompasso entre a realidade e as possibilidades vislumbradas de construção de um mundo novo. Vivendo esta incessante destruição e reconstrução das estruturas - físicas e intelectuais - o ambiente urbano, ao mesmo tempo intimidante e desafiador, possibilitou novas experiências e foi remodelado por elas, sendo a principal questão tratada pelas vanguardas no final do século XIX e início do XX. Dessa maneira, analisar este ambiente significou refazer uma parte do percurso desde a cidade industrial e pelas diversas utopias e teorias de renovação que este ambiente inspirou.

Entre elas, o Movimento Moderno, que em sua fase inicial, "teve fortes vínculos com movimentos de vanguarda como o futurismo e o construtivismo, compartilhando sua oposição à tradição" (HEYNEN, 1999, p. 26). Essas primeiras vanguardas trabalharam com o conceito transitório de modernidade, o qual foi gradualmente sendo substituído pelo Movimento Moderno, por um programa mais coeso de um discurso unívoco e com menos necessidade de redefinições dos objetivos. Sua principal característica é ter incorporado um conceito de arquitetura que constituiu uma resposta legítima à experiência da modernidade e aos problemas e possibilidades resultantes do processo de modernização. (HEYNEN, 1999, p. 27)

A arquitetura, as artes plásticas e o cinema tiveram de lidar com esses conceitos de transitoriedade introduzindo programas e formulações que retiravam do próprio ambiente industrial, das máquinas e das novas tecnologias. Uma nova concepção de espaço foi uma busca empreendida pelo Movimento Moderno, que, através dos avanços tecnológicos, transparências, vãos e novos instrumentos formais da abstração, tentou entender a evolução e a essência da arquitetura como criação de espaço. O conteúdo programático modernista tinha como objetivo amenizar os efeitos do adensamento e crescimento populacional nos centros urbanos 
advindos desde o século XVIII e XIX, ao propor eliminar a tradicional ruacorredor e liberar o solo urbano, inserir áreas verdes, vias de circulação e espaços livres para apropriação coletiva.

Observou-se um debate acerca da permanência e do fluxo. Sendo que a permanência é considerada um elemento importante na ideia de lugar, Gondim (2014, p. 12) justifica que "uma análise dirigida apenas aos espaços fixos, dissociada do movimento, sem contemplar a interferência de seus personagens, veículos e pedestres, interpreta apenas uma estrutura urbana e não uma cidade". Considera que "a rua é o espaço do movimento, é o lugar onde se manifesta a busca pela satisfação das necessidades, dos fluxos que mantêm a cidade viva" e assim, recoloca a sua importância, e também a do movimento e dos fluxos no debate sobre a construção do sentido de lugar. A intenção foi realizar uma abordagem de algumas características mais marcantes das vanguardas, do Movimento Moderno e relacioná-las com o cinema, para alcançar os objetivos desse trabalho: como o cinema retratou as cidades, como foi influenciado por elas, e de que maneira a imagem em movimento pode servir como instrumento de análise das cidades, enquanto espaço compartilhado e vivenciado. 


\section{Modernização e urbanização no Brasil: conexões entre a arquitetura e o cinema}

As mudanças ocorridas no Brasil relacionadas à movimentação cultural que influenciou os movimentos artísticos de vanguarda no cinema e na arquitetura, e seus esforços na busca por uma identidade brasileira marcaram o ambiente urbano, no período que abrange desde a formação das grandes cidades no século XX, e que coincide com a chegada do cinema no Brasil em $1898^{19}$ e encontra seu ápice com a inauguração de uma nova capital, Brasília.

Este capítulo fará um percurso pelas vanguardas artísticas, para compreender de que maneira a conjuntura social, política e econômica influenciou essas linguagens na representação do urbano. Focando nas suas representações no cinema, desde as primeiras salas de cinema no Rio de Janeiro, no final do século XIX, e nas artes plásticas, desde A Semana de Arte Moderna de 1922, até o movimento do Cinema Novo e do Cinema Marginal $^{20}$, que coincidem com o momento da realização de Brasília.

Assim, na primeira parte, o tema dará oportunidade para tratar das questões da busca de identidade no processo de modernização, quando a Semana de Arte Moderna de 1922 será o guia. A segunda parte avança na questão das experiências vanguardistas, focando nas décadas de $195^{\circ} \mathrm{e}$ 1960 e nos movimentos concretos, período de desenvolvimento econômico e surgimento das grandes cidades no Brasil. Na terceira parte, o foco no surgimento da arquitetura moderna brasileira, induzida, entre outras coisas, pelo incentivo do Estado Novo, que buscava representação e encontra na arquitetura um instrumento de muito valor simbólico, e resulta, com o governo democrático de Juscelino Kubitschek, na

${ }^{19}$ Segundo Caldas e Montoro (2006, p.26 a 30), 1898 foi o ano em que Afonso Segretto, irmão de Paschoal Segretto - dono da sala de exibição de filmes "Salão de Paris", no Rio de Janeiro - tirou algumas "vistas" da Baía de Guanabara com a câmara de filmar comprada em Paris. Ainda segundo os autores, este marco representa a expansão cultural, como sinal de modernidade do país, grande sonho daquele momento.

${ }^{20} \mathrm{O}$ Cinema Marginal caracteriza-se por um conjunto heterogêneo de filmes realizados entre a década de 1960 e 1970 por diretores em geral bastante jovens, que romperam, no campo artístico, com o Cinema Novo, pois pretendiam continuar as experiências estéticas. Buscavam retomar o diálogo com as vanguardas do cinema mundial, as referências à indústria cultural retrabalhadas sem má consciência, a posição irônica com relação ao nacionalismo cultural do Cinema Novo, o humor escrachado e a desesperança para com qualquer forma de organização política. Fonte: Arthur Autran em "Panorama do Cinema Marginal", 2009. 
construção de Brasília. Na quarta parte, olhando pelas telas do cinema, a representação da cidade brasileira, especialmente no movimento do Cinema Novo, e seus questionamentos com relação à situação política, econômica e social do país.

\subsection{A Semana de 22: busca por modernidade}

No início do século XX, a sociedade no Brasil começa a vivenciar um impulso na urbanização, resultado de uma industrialização que se inicia com o incremento do comércio com os grandes centros manufatureiros do exterior, tornando algumas cidades polos efervescentes de ideias e informações. Em meio a essa euforia desenvolvimentista, a Semana de Arte Moderna de $1922^{21}$ e seus desdobramentos, como o "Manifesto da poesia pau-brasil"2" e o "Manifesto Antropofágico ${ }^{23}$ ", mostraram um espírito revolucionário imbuído de uma busca pela representação do Brasil e é considerado o evento precursor da vanguarda no Brasil. Aracy Amaral aponta para as principais conquistas deste movimento vanguardista:

Seu objetivo: a derrubada de todos os cânones que até então legitimavam entre nós a criação artística. Este objetivo destrutivo, claramente enunciado, traria, como mais tarde Mario de Andrade diria, o direito permanente à pesquisa estética, a atualização da inteligência artística brasileira e a estabilização de uma consciência criadora nacional. (AMARAL, 1998, p. 13)

Literatura, artes plásticas, cinema e arquitetura buscavam uma ruptura, não com o velho, o antigo e o tradicional como nas vanguardas europeias, mas uma ruptura com a colonização, com as velhas "escolas" e modos de fazer que não satisfaziam mais à sociedade, pelo menos à sua elite intelectual. A grande diferença para a vanguarda europeia está no fato de o Brasil não ter vivido as profundas transformações da era

${ }^{21}$ A "Semana de Arte Moderna", também chamada de Semana de 22, ocorreu em São Paulo no ano de 1922, entre os dias 11 a 18 de fevereiro, no Teatro Municipal da cidade, e vinha de encontro com as comemorações do Centenário da Independência do Brasil. Seu objetivo era renovar o ambiente artístico e cultural da cidade com "a perfeita demonstração do que há em nosso meio em escultura, arquitetura, música e literatura sob o ponto de vista rigorosamente atual", como informava o Correio Paulistano, órgão do partido governista paulista, em 29 de janeiro de 1922.

${ }^{22}$ Oswald de Andrade, publicado no "Correio da Manhã", 18 de março de 1924.

${ }^{23}$ Oswald de Andrade, pulicado na "Revista de Antropofagia”, Ano I, N. I, em maio de 1928. 
industrial e suas principais cidades e capitais começavam apenas a conhecer o processo de urbanização $0^{24}$.

\begin{abstract}
Se for aceita a premissa de que a idade industrial provocou uma mudança profunda na função da arte e na natureza da imagem, e se for confrontado esse pressuposto com as concepções vigentes no Brasil no momento constitutivo do Modernismo, encontrar-se-á um quadro de referências bastante diferente daquele europeu, próximo de uma visão realista (quando não acadêmica), e avesso àquelas categorias antissublimes e desumanizadoras que representavam um dos traços fundamentais das vanguardas históricas. Tal diferença de enfoque não é casual, devendo ser reportada à questão da revolução tecnológica, muito mais um mito do que presença efetiva no Brasil do começo do século XX, que se projeta no universo do artifício por um desejo de atualização sem, contudo, ter vivido de perto as profundas transformações antropológicas engendradas pelo novo modelo de produção. (SCHWARTZ, 2002, p. 43)
\end{abstract}

É relevante nesse contexto apresentado por Schwartz compreender como as vanguardas artísticas no Brasil trouxeram uma questão diferencial, defendida também por Antonio Risério, em "A Cidade no Brasil" (2012), de que a vanguarda não se distanciou tanto assim da tradição, como ocorreu no cenário europeu. O diálogo entre tradição e vanguarda seria uma característica central da cultura brasileira, que aplicaria as lições do passado em seus experimentos de vanguarda, na posição de busca da história e não de sua negação.

A partir do exposto por Schwartz, Risério e Amaral, pode-se então verificar que a vanguarda brasileira partiu para uma busca por seus referentes no passado, por raízes e origens de uma cultura mais "autêntica" e "genuína", e que pudesse constituir uma base sólida para um desenvolvimento em direção a um futuro, menos dependente de ideias importadas.

O papel almejado pelos modernistas da década de 1920 era mostrar o Brasil esquecido até então pelas artes, pelas políticas de desenvolvimento e pela população de um modo geral ao "assumir nossa realidade física e simultaneamente, as expressões culturais até então menosprezadas pelas elites que se identificavam com a Europa" (AMARAL, 1998, p. 22) mas que, no entanto, ainda traziam referências bastante contagiadas pelas artes europeias, já que seus principais representantes eram ou nascidos ou formados na Europa.

\footnotetext{
${ }^{24}$ “Quando do primeiro censo demográfico realizado no Brasil, em 1872, São Paulo ocupava um modesto nono lugar entre as nossas capitais. Trinta anos depois, em 1900, já havia se tornado a segunda maior cidade do país. E estava iniciando seu avanço em direção ao topo, pole position que alcançaria ao longo da década de cinquenta" (FICHER, 1998).
} 
No Brasil, internacionalismo e nacionalismo foram simultaneamente as características básicas do movimento modernista ocorrido nas letras e artes a partir de meados da segunda década do século. Mas a "redescoberta" do país, como escreveu o crítico Lourival Gomes Machado, "viaja o duplo roteiro dos navios que levam ao Havre e dos trens que conduzem a Ouro Preto", ao fazer referências às viagens à Europa pelos modernistas e ao redescobrimento de uma cultura brasileira, a seu retorno do exterior. (AMARAL, 1998, p. 21)

Na obra de Tarsila do Amaral (1886 - 1973) percebe-se a conciliação de uma formação moderna ${ }^{25}$ com um conjunto de signos formais provenientes da cultura popular brasileira. No entanto, a sua figuração da cidade, ao conciliar duas culturas e sistemas formais diferentes realiza harmoniosamente uma "utopia visual", ao que Icleia Cattani (apud FABRIS, 2002, p. 45) denomina "lugares incertos" e, portanto, distante do espaço real da cidade.

A cidade, que é concebida pelos cubistas como um espetáculo heterogêneo, feito de dissonâncias e descontinuidades, de desintegrações e simultaneidades, aparece de maneira singular no imaginário de Tarsila do Amaral. Longe de ser o espaço da transformação e do trânsito constante de signos - como afirmam seus companheiros literatos - configura-se como um espaço vazio e geometricamente determinado, despido de toda tensão em virtude da presença de artefatos tecnológicos tratados de maneira totêmica. (SCHWARTZ, 2002, p. 46)

Fabris, Cattani e Schwartz chamam atenção para a representação da cidade na obra de Tarsila, diferente do que vimos na imagem sobreposta da representação de fluxo e velocidade do cubismo e futurismo, por exemplo: a cidade de Tarsila contém elementos geometrizados, porém, é estática e harmoniosa, mesmo com a presença do trem e da fábrica, ainda tratados em segundo plano (Erro! Fonte de referência não encontrada.).

${ }^{25}$ Tarsila do Amaral esteve em Paris, quando teve aulas com Léger, Lhote, entre outros artistas modernos. Schwartz (2002, p.45) especifica o ano de 1923, no qual Tarsila teria tido aulas com Lhote. 


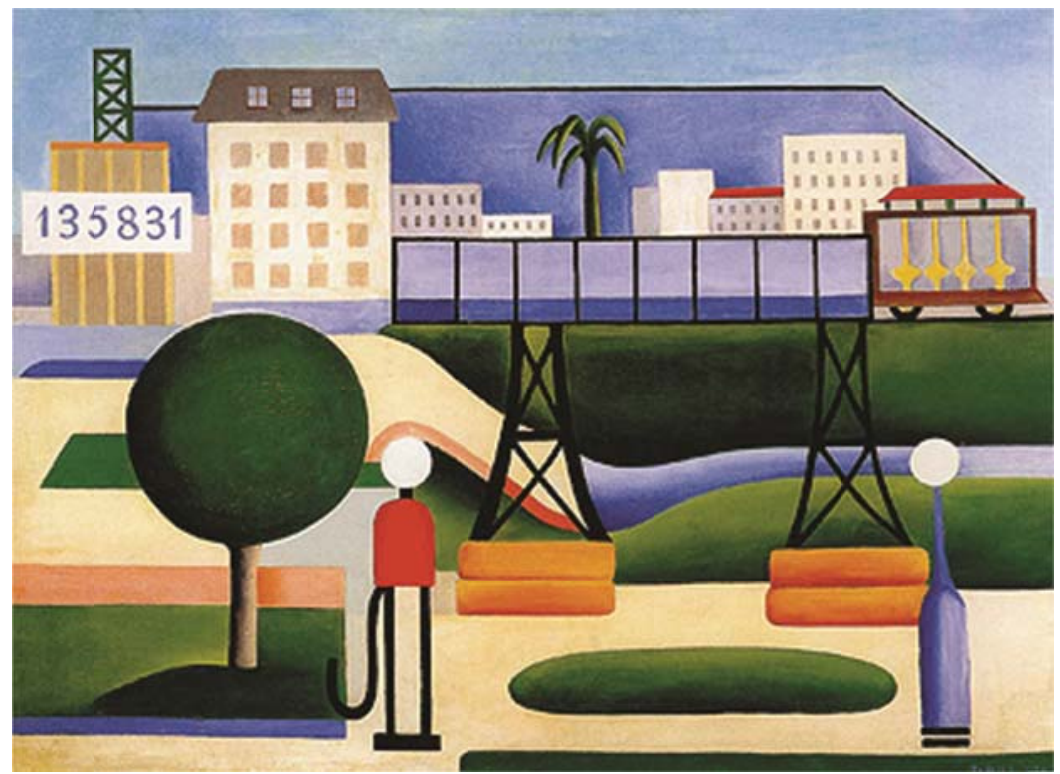

Figura 26: "São Paulo", Tarsila do Amaral, 1924. Fonte: SCHWARTZ, 2002, p. 67 .

O intercâmbio de ideias vanguardistas entre o Brasil e a Europa era feito a partir de revistas e jornais que publicavam os principais manifestos artísticos das vanguardas. A revista Klaxon (1922-1923) foi um desses veículos e seus textos alimentaram todo o grupo de intelectuais que promoviam eventos para discussões sobre a arte no Brasil, tendo relação direta com a Semana de Arte Moderna de 1922.

De acordo com Fabris (2011), na revista Klaxon, o cinema foi tratado com bastante entusiasmo como forma de modernidade e visto como um modo de mudança de percepção e sensibilidade, uma linguagem útil às propostas de "um mundo novo" almejado pelas vanguardas brasileiras como questão essencial na luta por mudanças por meio da apologia do progresso.

No manifesto de apresentação de Klaxon, o cinema é mencionado várias vezes, atestando a importância que lhe era conferida pelos modernistas na constituição de uma estética contemporânea. Ele não só podia servir de lição, como ser um paradigma para opor o modo de pensar oitocentista à mentalidarde moderna. Os klaxistas entenderam o alcance do cinema em sua capacidade de propor novos comportamentos e novos modos de percepção, ao evidenciarem a ligação que ele permitia estabelecer entre horizonte tecnológico e modernidade: (FABRIS, 2011).

No entanto, na Semana de Arte Moderna de 22 o cinema estivera ausente, pois não havia uma prática cinematográfica "modernista" e brasileira. Mário de Andrade escreveu a maioria dos textos sobre cinema na Klaxon, de críticas cinematográficas a comentários sobre Chaplin, mas a produção de filmes no Brasil ainda não havia conquistado uma modernidade de linguagem ou discurso. (XAVIER, 1978, p. 149) 
Na arquitetura, porém, há um forte intercâmbio, e Aracy Amaral cita diversos exemplos da conexão que existia entre a linguagem desses modernistas e do estilo arquitetônico Art Déco, amplamente difundido em Paris, fonte de onde bebiam os artistas brasileiros.

A tal ponto é poderosa a influência do Art Déco, ou seja, do "moderno" em geral, sobre os artistas brasileiros, que alguns não acusam a influência de uma ou outra personalidade artística da Escola de Paris desse período, mas assiinalam em seu trabalho a influência direta do difuso Art Déco. É o caso de Antonio Gomide, Regina Graz, Ismael Nery, Rêgo Monteiro e Brecheret, assim como Tarsila e Di Cavalcanti. (AMARAL, 1998, p. 42)

A clareza dessa influência está na produção de artigos de decoração como tapeçarias, panneaux, vitrais e luminárias usando formas geométricas abstratas, motivos indígenas e composições com paisagens bucólicas usadas pelos artistas Antônio Gomide e Regina Gomide Graz, nas esculturas estilizadas de Brecheret, na decoração do teto do Pavilhão Moderno (1925) de D. Olivia Guedes Penteado e na obra de Tarsila "Sol poente" (Figura 27), entre outros (AMARAL, 1998, p. 40-45).

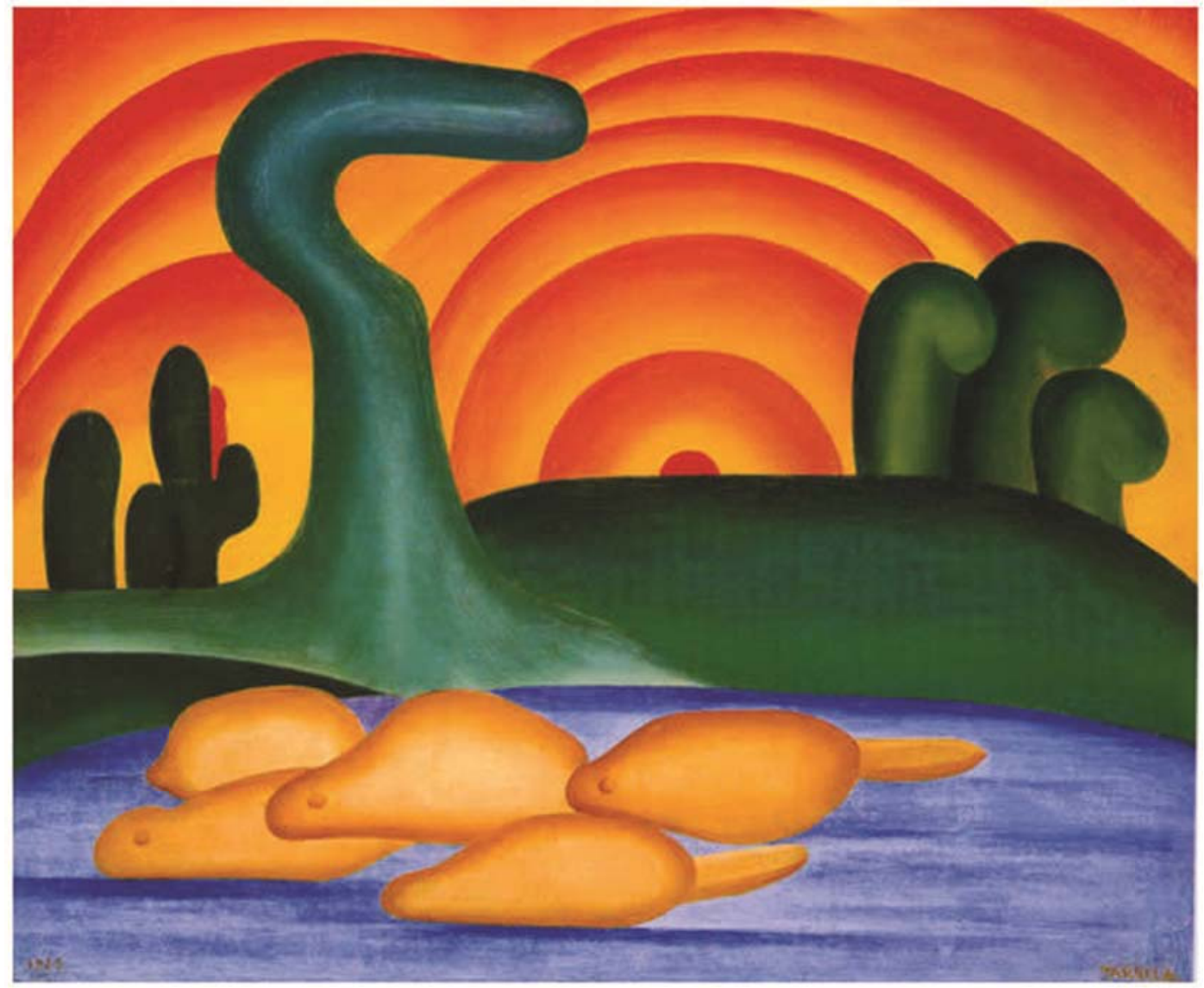

Figura 27: "Sol poente", Tarsila do Amaral, 1929. Fonte: SCHWARTZ, 2002, p. 64.

Segundo Aracy Amaral (1998, p. 24) o aguçamento da percepção sensível em relação à nossa realidade local se daria, contraditoriamente, 
em decorrência da ampliação dos horizontes culturais pela vivência europeia. No entanto, o espírito de modernidade confundia-se com o espírito de brasilidade e percebe-se um acirramento do ânimo nativista, pelos preparativos da comemoração do Centenário da Independência, em 1922, e a importância do sentimento cívico. Ainda segundo a autora (1998, p. 28), esse nativismo "antecede o nacionalismo exaltado (...) e se confunde com o modernismo, na medida em que significa também universalismo, ou seja, busca da atualização da inteligência brasileira". Significa que o modernismo não teve apenas um papel estético, mas representou um estado de espírito revolucionário, que prepararia o campo para outras manifestações sociais, em decorrência das sistematizações e investigações que promoveu.

\footnotetext{
Realmente, pouco havia de "moderno" em São Paulo em 1922. (...) Com algumas exceções, as obras apresentadas no saguão do Teatro Municipal estavam muito distantes daquilo que se poderia denominar como "vanguarda" do tempo internacional. Porém, mesmo que não fosse vanguarda, aquilo que foi apresentado chocou. O grupo que rejeitava o passadismo era vitorioso na intenção demolidora. Inexistente a qualidade, a segurança de linguagem, a audácia maior, estavam presentes, contudo, a inquietação, em sintonia com o país, e a percepção da necessidade de mudança. (AMARAL, 1998, p. 16)
}

No ano de 1929, a candidatura de Julio Prestes, então presidente de São Paulo, instaurou uma crise no governo pela ameaça de rompimento com a aliança "café com leite ${ }^{26 ”}$. Causando o fortalecimento do gaúcho Getúlio Vargas, candidato apoiado pela "oposição" mineira e a formação de novas alianças políticas, somado à crise econômica causada pela quebra da bolsa de Nova York em 1929, a revolução armada tomou o poder por meio de um golpe de Estado em outubro de 1930. O historiador Eduardo Bueno (2003) identifica assim este novo momento político:

Surgia um Estado forte, paternalista, centralizador e nacionalista. Acabava-se o federalismo descentralizado e liberal da "república dos fazendeiros". A intervenção do Estado na economia crescia: os sindicatos e as relações trabalhistas passaram a ser controladas pelo governo. (BUENO, 2003, p. 327)

A partir da década de 1930, o Brasil se estabelece com maior poder econômico nos setores urbanos de classe média, da burguesia industrial, sobretudo após a Revolução de 1930 e a instauração do Estado Novo em 1937, quando o presidente Getúlio Vargas empreendeu projetos de

\footnotetext{
${ }^{26}$ Aliança entre os dois estados mais poderosos, São Paulo e Minas Gerais, que se estabeleceu desde 1914 pelo Pacto de Ouro Fino, na qual a presidência do país se revezaria entre representantes dos dois estados. (BUENO, 2003, p. 327)
} 
industrialização e reformas sociais, administrativas e políticas. Getúlio Vargas ficou no poder durante $25 \operatorname{anos}^{27}$.

O período pós Segunda Guerra representou, no Brasil, o intercâmbio internacional da arte e da arquitetura moderna brasileira, criação dos mais importantes museus (MASP em 1947, MAM/RJ e MAM/SP em 1948), assim como a primeira Bienal de Artes de São Paulo, em 1951, influenciando toda uma geração de artistas brasileiros. Esse intercâmbio impactou e promoveu modificações no meio social e cultural brasileiro neste cenário de industrialização, metropolização e pela pauta desenvolvimentista que alteraram a paisagem urbana.

\subsection{Movimentos concretistas: geometria e corporeidade}

A vontade de ser moderno e pensar o futuro estavam presentes, notadamente para a elite cultural consumidora das novas formas de entretenimento, como a televisão que chegou em 1951 com a fundação da TV Tupi. A criação de dois grandes estúdios de cinema (Vera Cruz, em São Paulo em 1949, e Atlântida, no Rio de Janeiro em 1941) proporcionaram uma notável melhoria técnica e a produção das conhecidas "chanchadas", assim como o surgimento de diversas vertentes artísticas, como a arte concreta, que ressurge na Europa no pós-guerra e afeta diretamente a arte brasileira.

A partir da influência do artista concretista e arquiteto suíço Max Bill, que expôs suas obras no Brasil, na Bienal de São Paulo de 1951, o Grupo Ruptura, assimilou esse momento e procurou captar aspectos da urbanização e da comunicação em massa e dos avanços tecnológicos que transformavam a realidade, aspectos estes que já eram representados na Europa pelas vanguardas do início do século e que somente neste momento aparecem com maior força na arte brasileira.

No entanto, segundo Ronaldo Brito (1985, p. 30), "a formação mais ou menos simultânea, de uma vanguarda de linguagem geométrica no Rio de Janeiro e em São Paulo, no início dos anos 50, obedecia a razões mais significativas do que simplesmente ao entusiasmo por recentes exposições de Max Bill, Calder ou Mondrian". Devia-se de maneira mais estrutural à evolução que estas representavam para os artistas brasileiros de classe média e ao que traziam de novo no processo de leitura e percepção da realidade. As Figura 28 e Figura 29 mostram a linguagem geométrica na obra de Max Bill e do artista brasileiro Waldemar Cordeiro.

\footnotetext{
${ }^{27}$ Houve um intervalo entre 1945 e 1950, quando Getúlio Vargas foi afastado do poder. No entanto, continuou participando ativamente da política até ser eleito em 1950.
} 


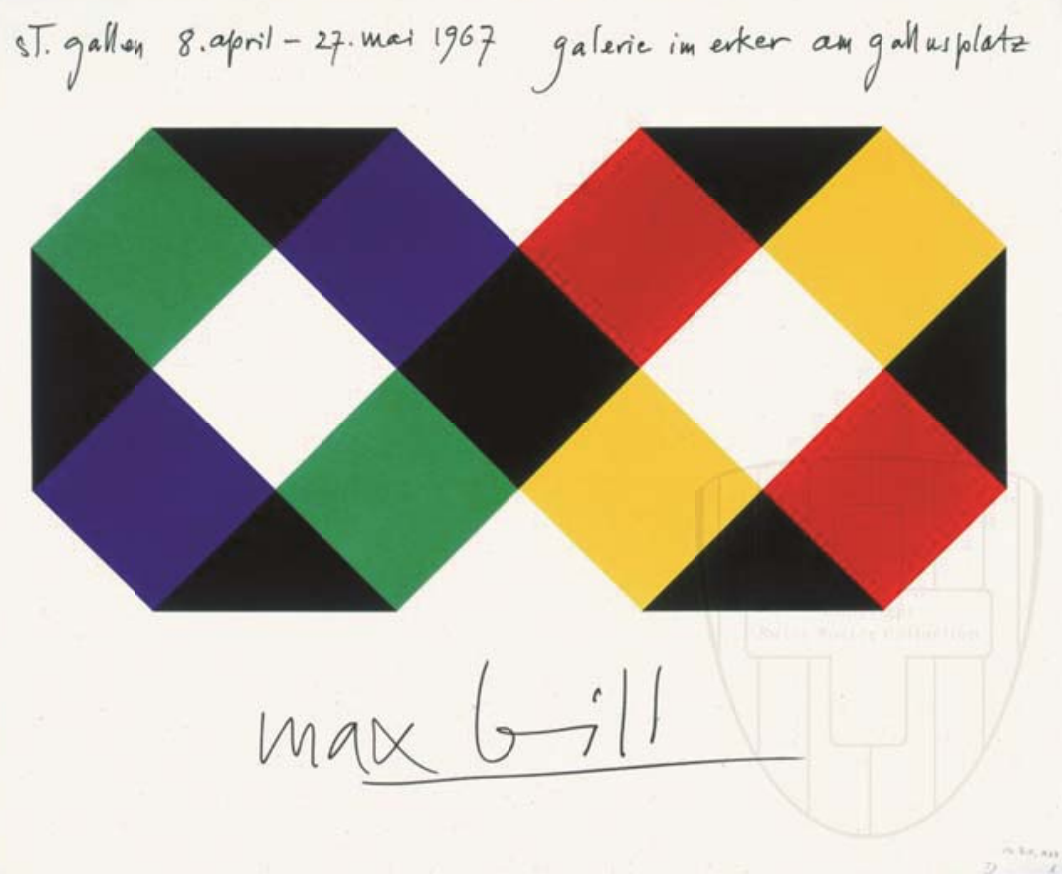

Figura 28: Max Bill, 1967. Fonte: Enciclopédia de Artes Visuais Itaú Cultural, acesso em julho de 2013.

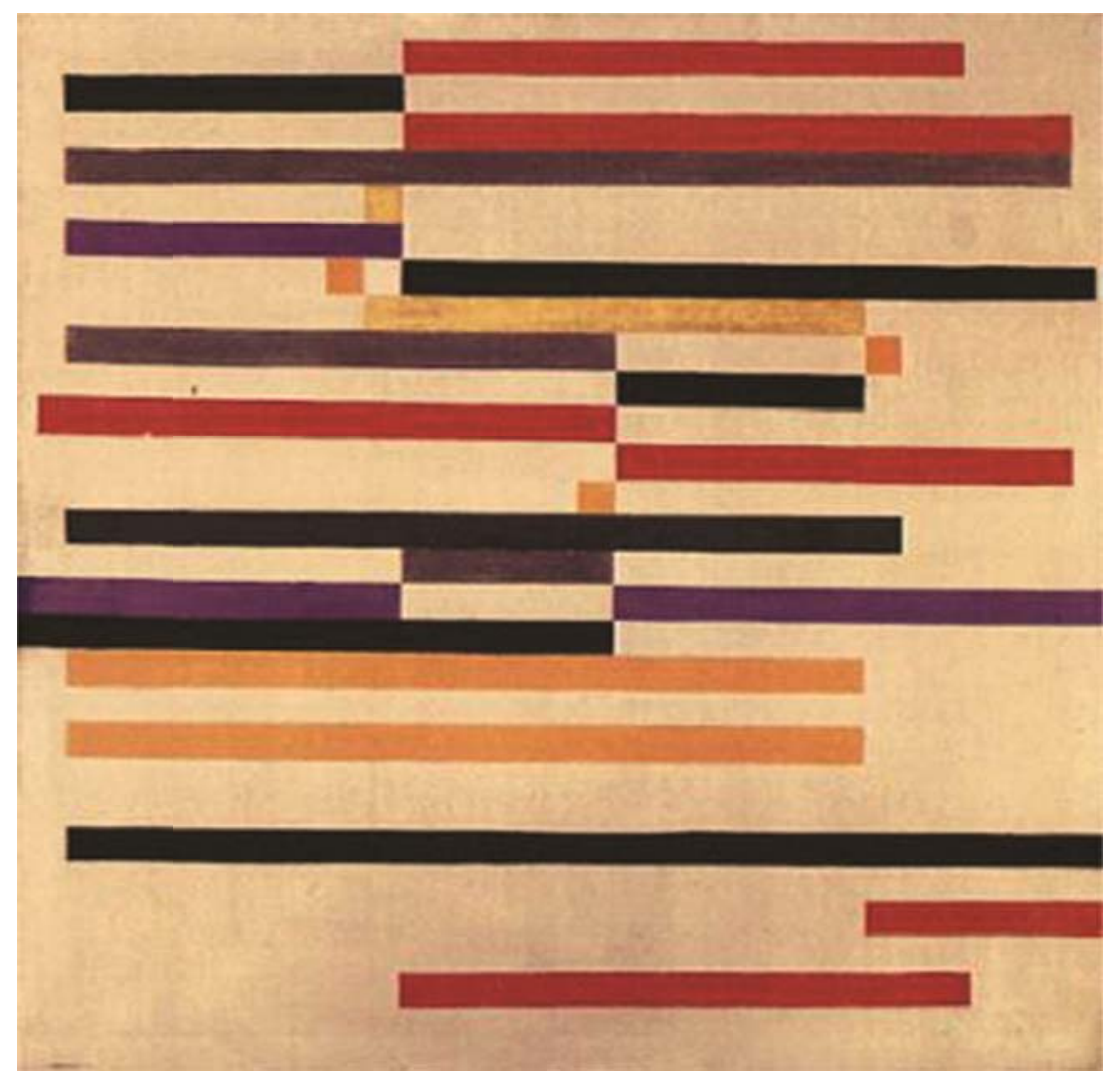

Figura 29: Waldemar Cordeiro, "Movimento", 1951. Fonte: Enciclopédia de Artes Visuais Itaú Cultural, acesso em julho de 2013. 
Para Brito (1985, p. 30-34), os modernistas da década de 1920 proporcionaram uma nova relação entre artista e arte, mas ainda não haviam conseguido realizar de fato um rompimento com os antigos esquemas de representação. Coube a esse novo movimento de vanguarda realizá-lo a partir da relação entre arte e realidade, relação esta que somente a vanguarda construtiva conseguiu inaugurar no Brasil. A arte concreta representava um amadurecimento das pesquisas das vanguardas, pela integração da arte na sociedade industrial, pelo seu caráter sistemático, universalista e evolucionista.

Brito acrescenta que estas ideologias construtivas estão ligadas ao desenvolvimento cultural da América Latina no período de 1940 a 1960, por se encaixarem nos projetos reformistas e aceleradores e serviram como agentes da libertação nacional. "Mobilizava-se totalmente no sentido de estabelecer uma dinâmica progressista no campo cultural do país" (BRITO, 1985, p. 53). O concretismo pretendia intervir na produção industrial com o objetivo de uma transformação no ambiente social e acreditava que a comunicação de massa poderia ser utilizada para as transformações culturais que tirariam o país do subdesenvolvimento, aumentando a difusão e aproximando a arte da realidade. O Grupo Ruptura buscava a inserção da arte na sociedade industrial, onde o objeto artístico representava a materialização de uma ideia da maneira inteligível, por meio de uma base racional, como demostra Brito a partir da citação de Van Doesburg a respeito desta "concretização" do real:

Pintura concreta e não abstrata, porque já passamos o período das pesquisas e experiências especulativas. Em busca da pureza eram os artistas obrigados a abstrair as formas naturais que escondem os elementos plásticos... Pintura concreta e não abstrata, porque nada mais concreto, mais real que uma linha, uma cor, uma superfície. (VAN DOESBURG apud BRITO, 1985, p. 34)

No entanto, o excesso de racionalização do Grupo Ruptura começou a criar divergências entre os artistas, especialmente entre Waldemar Cordeiro e Ferreira Gullar - resultando na fundação do Grupo Neoconcreto no Rio de Janeiro ${ }^{28}$. Após a queda de Getúlio Vargas, em 1954, e vivendo o primeiro período democrático desde 1930, com Juscelino Kubitschek na presidência da República, a economia do país progredia e o otimismo em relação ao futuro do país era grande. A crença no progresso movia a nação em busca de um desenvolvimento não só econômico, mas na sua capacidade de diminuir a disparidade social e na criação de uma sociedade mais igualitária.

\footnotetext{
${ }^{28}$ Para mais informações ver: site oficial da enciclopédia Itaú Cultural, disponível em http://www.itaucultural.org.br. Acessado em fevereiro de 2014.
} 
Vivia-se no país um processo de democratização política, desenvolvimento e abertura econômica, expansão da indústria automobilística, de eletrodomésticos, de novos meios de comunicação e maior intercâmbio nas artes. Mas a seca e a fome moviam populações em direção às grandes capitais em busca de melhores condições de vida e as principais cidades brasileiras já presenciavam crescimento e verticalização acelerados. Segundo Bueno (2003, p. 355), o país a partir de então "mais inchou do que cresceu", referindo-se às favelas e periferias que surgiam nessas cidades.

Diante disso, os artistas cariocas liderados por Ferreira Gullar, após o rompimento com os paulistas, lançam o "Manifesto Neoconcreto", em 1959, promovendo uma articulação forte entre arte e vida - afastando a consideração da obra como "máquina" ou "objeto", como defendia o Grupo Ruptura -, e uma ênfase maior na intuição como requisito fundamental do trabalho artístico.

Neste grupo se revela o trabalho de Hélio Oiticica, que cria objetos e instalações artísticas que reproduzem o ambiente da favela carioca, transmitindo sua fragmentação e a fluidez de um espaço em constante reformulação e construção. A arte de Oiticica mostrou a realidade das favelas em museus de arte, fazendo colidir a realidade da cidade com a imagem progressista e moderna protagonizada pela elite cultural. Seus "parangolés" (Figura 30 e Figura 31) e "penetráveis" mostravam o movimento da dança e da música da mesma forma que representavam o ambiente caótico e dinâmico das favelas. Eram obras de arte participativas nas quais o objeto não era capaz de obter vida sem que estivesse literalmente vestido no corpo. Pela dramatização, os neoconcretistas buscavam a sensibilização do trabalho de arte, para conservar a "aura" perdida e fornecer informação qualitativa à produção industrial. (LIMA, 1996) (BRITO, 1985) (GULLAR, 1984)

O neoconcretismo repunha a colocação do homem como ser no mundo e pretendia pensar a arte nesse contexto: tratava-se de pensá-lo enquanto totalidade. Era o retorno das intenções expressivas ao centro do trabalho da arte. Resgatava-se a noção tradicional de subjetividade contra o privilégio da objetividade concreta. (BRITO, 1985 , p. 51) 


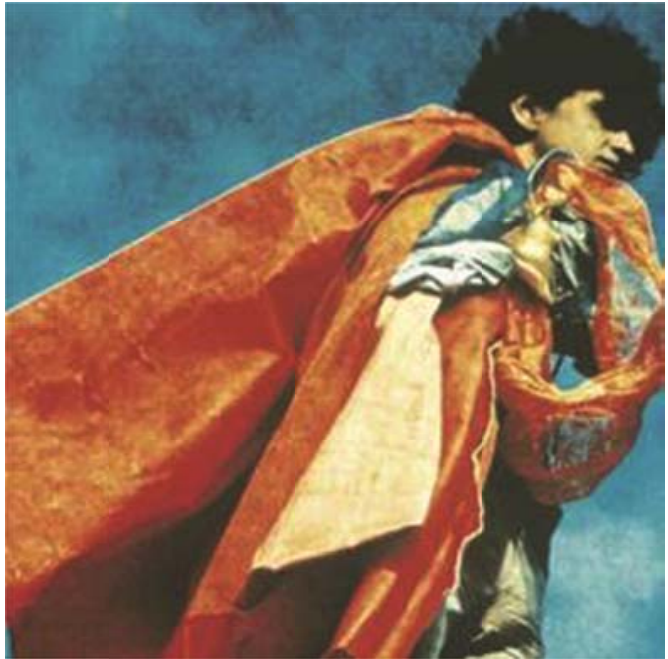

Figura 30: "Caetano Veloso com Parangolé Hélio Oiticica”. Foto: Geraldo Viola. Fonte: Marginália Arte \& Cultura "na idade da pedrada”, Marisa Alvarez Lima, 1996.

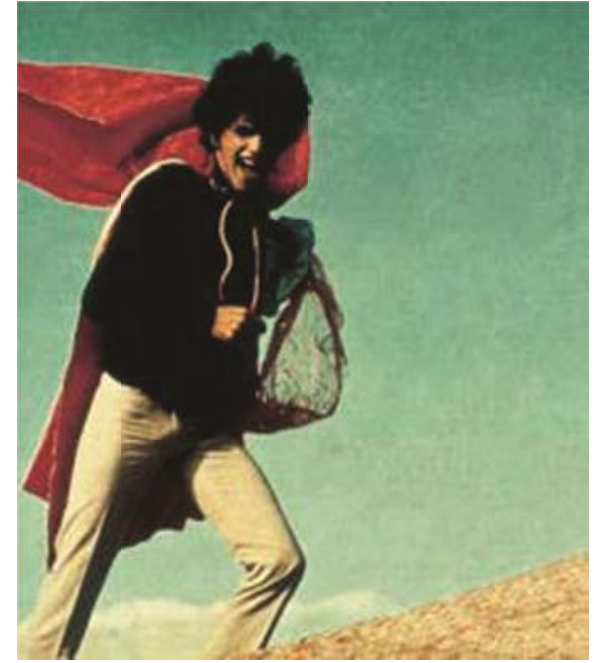

Figura 31: "Caetano Veloso com Parangolé, Hélio Oiticica”. Foto: Geraldo Viola. Fonte: Marginália Arte \& Cultura "na idade da pedrada”, Marisa Alvarez Lima, 1996.

Brito (1985, p. 49) defende que o neoconcretismo representou a um só tempo o vértice do movimento construtivo no Brasil e sua explosão, por representar a consciência da impossibilidade da vigência dos elementos da tradição construtiva como projeto de vanguarda cultural brasileira. Cita Frederico Morais e sua observação: "o neoconcretismo fez um retorno ao humanismo frente ao cientifismo concreto" (apud BRITO, 1985, p. 49).

A questão do tempo foi determinante para as diversas tendências construtivas a partir dos anos 196o. "Haveria, pois, que pensá-lo enquanto movimento, estímulo perceptivo atual, elemento concreto do repertório das artes visuais" (BRITO, 1985, p. 68). Aí talvez resida a principal polêmica e ruptura entre as duas posições concretas e neoconcretas, pois a primeira, apoiada no racionalismo positivista, com uma leitura construtiva, absorvia o tempo na obra de arte a partir de movimentos mecânicos e como funcionamento.

Contra o tempo "interior", imóvel, aspirante à eternidade, da obra de arte tradicional, a ala mais cientifista das tendências construtivas privilegiava o movimento mecânico como propriedade do trabalho de arte e abriria assim uma porta para a participação mais direta da tecnologia na realização dos trabalhos. (BRITO, 19885, p. 67)

Já no neoconcretismo, "à ideia concreta de tempo como movimento mecânico ele opôs o tempo como duração e como virtualidade” (BRITO, 1985, p. 68). Nesta posição mais idealista e fenomenológica:

Convém lembrar, porẻm, que no âmbito de um movimento comprometido com a leitura construtiva da arte pós-cubista, chegar a introduzir Bergson - com sua doutrina intuicionista e sua ideia de tempo como duração - é quase um escândalo. E, no entanto era de algum modo pertinente ao projeto neoconcreto: servia e estava 
associado à proposta de "ativar" o relacionamento do sujeito como trabalho e permitir múltiplas possibilidades da leitura, "abertas" no tempo. (BRITO, 1985, p. 69)

Nesse sentido, percebe-se que, diferentemente do concretismo, para quem o tempo tinha uma dimensão objetiva, operacional e informacional, no neoconcretismo era uma "proposição de vivências (...). O tempo neoconcreto é fenomenológico, recuperação do vivido, repontecialização do vivido" (BRITO, 1985, p. 70). As obras e proposições concretistas trabalhavam com engrenagens que se movimentavam; já no neoconcretismo o espaço ao redor e o "público" fazem parte da experiência da obra de arte, que não é mais observada e passa a interagir com o mundo, fazendo com que o corpo movimente e seja movido pela obra.

Em torno da década de 1960 a problemática estética das vanguardas começa a dar lugar a uma arte participante, que usava da poesia, teatro e cinema como instrumentos de ação e denúncia. O período de desenvolvimento econômico não havia resultado na diminuição das desigualdades sociais no país e foi quando os Centros Populares de Cultura (CPCs), associados à União Nacional dos Estudantes (UNE), no Rio de janeiro, adquiriram importância.

Inicia-se um debate denso no período de forte transição política, cultural e estética ao longo dos anos 6o-70 em que o cinema, o teatro, as artes visuais e a música popular estabeleceram uma constante interação, após a síntese de um legado construído desde o modernismo da década de 1920, passando pelo momento nacional-desenvolvimentista dos anos 1950 e definindo um campo de confrontos polarizados na década de 1960 .

\subsection{Arquitetura moderna brasileira: a experiência vanguardista e a construção da identidade nacional}

Um impulso de modernização começou a se desenhar na arquitetura a partir de experimentações em novos materiais e tecnologias, como o concreto armado. Mesmo incorporando os principais ideários da arquitetura mundial, os arquitetos brasileiros procuraram absorvê-los e modificá-los em direção a uma expressão própria e de debates sobre a identidade da arte brasileira, a partir de investigações inspiradas na arte tradicional, demonstrando a possibilidade de elaborar um projeto artístico moderno e nacional a um só tempo.

No contexto do Movimento Moderno, a arquitetura brasileira desenvolveu algumas peculiaridades; mesmo sob influência do ideário do modernismo europeu, incorporou suas próprias referências, estabelecendo um caminho contínuo em direção a uma clareza de seus princípios e paradigmas. 
Alguns autores, entre eles Hugo Segawa (Arquiteturas no Brasil 19001990, 2010), defendem que o impulso de modernização na arquitetura brasileira começou pelas pesquisas e experiências com o neocolonial. Assim como nas vanguardas da década de 1920, a arquitetura também foi buscar em suas raízes a origem e o propósito para iniciar uma nova pesquisa estética. Para Mindlin, em "Arquitetura moderna no Brasil" (1999, p. 25), "o protesto (contra o exagero dos estilos "imitativos") acabaria, mais tarde, por assumir a forma que assumiu no Brasil: a de uma reação neocolonial, vista por muitos como um retorno à única tradição legítima".

No período, o que se considerava "moderno" em arquitetura no Brasil era uma busca por uma nova identidade nacional com experimentações tradicionalistas, nativistas e regionalistas: estilo no qual Lucio Costa chegou a desenvolver diversas pesquisas e projetos de arquitetura.

Se essa reação levou arquitetos menos abertos a uma nova série de pastiches, para outros, como Lucio Costa, ela clareou rapidamente o problema, levando-os a retomar a tradição de uma construção mais próxima da realidade brasileira, a única que, o responder diretamente às exigências do clima e dos materiais, assim como às necessidades do povo, poderia servir de base e de ponto de partida para uma interpretação construtiva das necessidades arquitetônicas do Brasil no pós-guerra. (MINDLIN, 1999, p. 25)

O Brasil experimentava concomitantemente as várias vertentes de formulações arquitetônicas pós-Primeira Guerra, como o Art Déco, por exemplo. O Movimento Moderno ainda era desconhecido por aqui e apenas iniciava seus primeiros passos na Europa, em especial na Alemanha.

Mas, em 1925, a arquitetura "sente o impacto da Semana de Arte Moderna” (MINDLIN, 1999, p. 26), quando o arquiteto ucraniano Gregori Warchavchik (1896 - 1972), recém-chegado ao Brasil, escreve um texto em defesa da arquitetura moderna. Este texto é considerado por muitos o marco iniciador da arquitetura moderna no Brasil. Warchavchik constrói a própria casa, na Rua Santa Cruz, também considerada a primeira residência moderna no país. Nessa residência utilizou elementos formais da arquitetura moderna, apesar das dificuldades técnicas enfrentadas pela falta de tecnologia e materiais adequados no país (Figura 32). Segawa (2010, p. 54) diz que é "inegável a sua contribuição como pioneiro, ao postular publicamente posições referenciadas na arquitetura racionalista de vanguarda da Europa e, sobretudo, por introduzir, de forma ampla, o debate público acerca da modernidade arquitetônica". Neste texto de Warchavchik, "Acerca da arquitetura moderna" (1925), ficam claras as influências das vanguardas europeias, em especial no que diz respeito ao ideário da máquina, e a influência do arquiteto Le Corbusier, quando coloca já em suas primeiras linhas que: "observando as máquinas do nosso 
tempo, automóveis, vapores, locomotivas etc. nelas encontramos, a par da racionalidade da construção, também uma beleza de formas e linhas".

(WARCHAVCHIK, 2002, p. 506)

E afirma a necessidade de superar os preconceitos estilísticos ao propor uma nova diretriz para a arquitetura:

Construir uma casa a mais cômoda possível, eis o que deve preocupar o arquiteto construtor da nossa época de pequeno capitalismo onde a questão da economia predomina sobre todas as demais. A beleza da fachada tem que resultar da racionalidade do plano da disposição interior, como a forma da máquina é determinada pelo mecanismo que é a sua alma. (WARCHAVCHIK, 2002, p. 506)

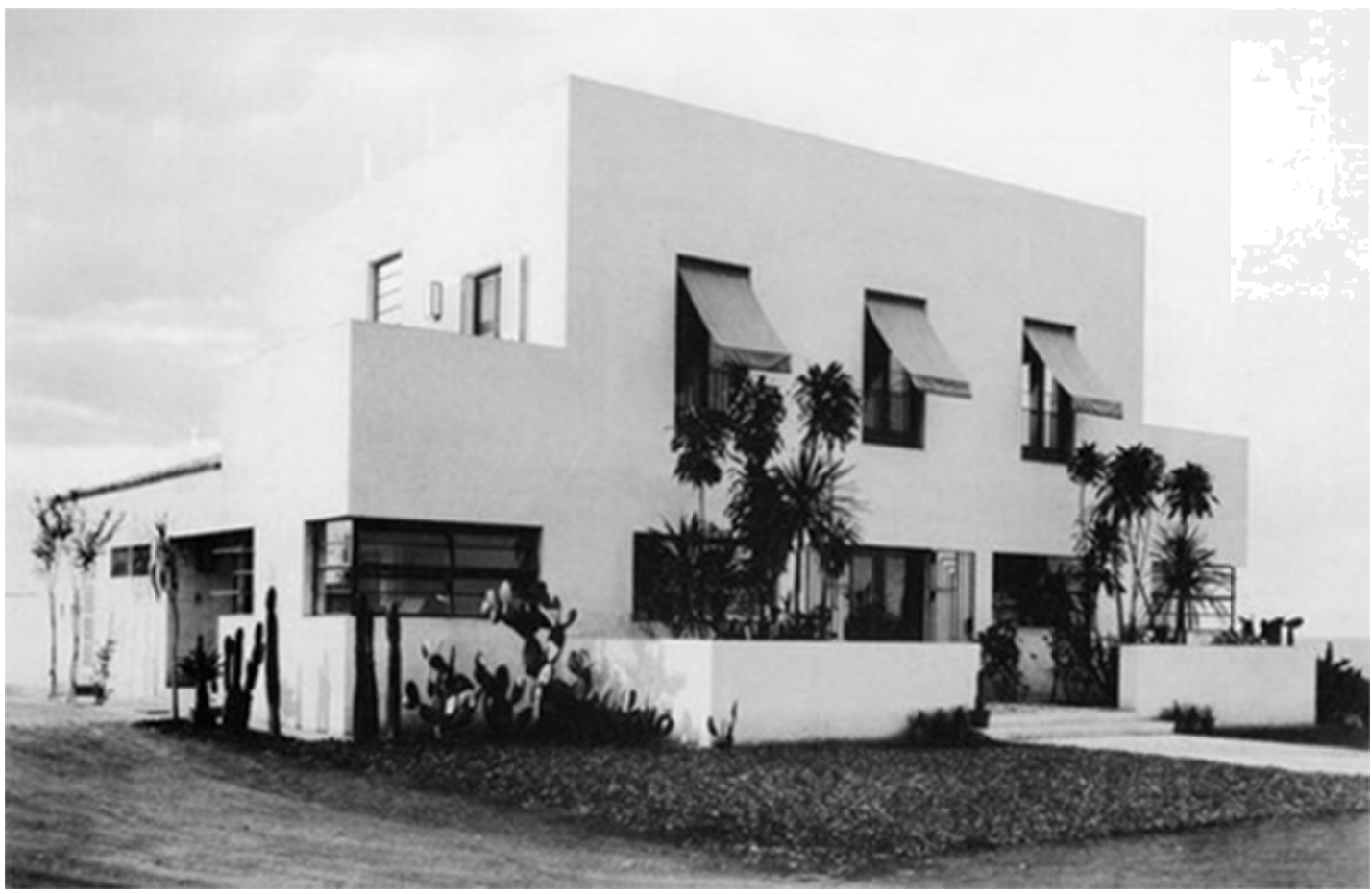

Figura 32: Gregori Warchavchik, 1928, Casa na Rua Santa Cruz, São Paulo. Fonte: MARTINS, 2002.

As características modernistas também se apresentam no projeto de "Cidade Futurista", de Flávio de Carvalho, durante o "Congresso Panamericano de 1930", quando publica manifestação em reportagem do Diário da Noite e propõe um cenário futurista para São Paulo:

Os carros elétricos transitariam quase sem impedimento entre os apoios dos prédios, cortando o mais possível em linhas retas, aumentando consideravelmente a velocidade, tornando maior a eficiência da vida e a consequente felicidade do homem. (DAHER, 1982, p. 34)

Rino Levi, que havia publicado o manifesto "A arquitetura e a estética das cidades", ainda estudante de arquitetura em Roma, retorna ao Brasil em 1928 e une-se ao grupo de arquitetos que contribuíram para a 
implantação da arquitetura moderna no Brasil. Destaca-se neste momento a atuação dos arquitetos Lucio Costa, Affonso Eduardo Reidy e o ainda estudante Oscar Niemeyer, no Rio de Janeiro, assim como Flavio de Carvalho, em São Paulo, nas primeiras incursões pela nova linguagem. As propostas desses arquitetos representavam apenas uma das diversas vertentes - como o Art Déco, por exemplo - desse período.

Em meio a uma paisagem dominada pela arquitetura eclética, o Art Déco apresentou pela sua monumentalidade, pela simetria e pela leveza da estrutura, uma imagem de modernidade. O Art Déco, ao mesmo tempo em que transmitia a sobriedade de seus elementos decorativos clássicos e sua simetria, utilizava as novas técnicas construtivas para conceber amplos espaços usados para a implantação de salas de cinema, teatros e grandes magazines, com vitrines em vidro e galerias, que modificaram a experiência dos habitantes nas ruas das grandes cidades.

No âmbito dessas vertentes e experimentações no campo da arquitetura, o edifício do Ministério de Educação e Saúde - MES (1936 1945), projetado pela equipe de Lucio Costa, destaca-se pela incorporação de elementos como os pilotis em dupla altura, marcando o acesso com ritmo e permeabilidade. Adrian Gorelik (2005) coloca o Ministério da Educação como um divisor de águas, "porque fecha um período de intensa experimentação vanguardista, conformando o modo canônico capaz de acolher e homogeneizar qualquer outro tipo de busca" (2005, p. 161) e que a afirmação "a arquitetura moderna brasileira" nasceu com este projeto e tem no fundo uma outra verdade: o que nasceu no Rio de Janeiro, sob o comando de Lucio Costa, foi um eficaz dispositivo de produção simbólica que tornaria célebre nos anos 1940 e 1950 um "movimento", que se transformaria uma espécie de "selo" nacional, sobretudo pela relação dos arquitetos com o Estado. A arquitetura mostra-se um veículo de unificação simbólica nacional e como representação do Estado. De Getúlio Vargas a Juscelino Kubitschek (ou seja, no período de 1930 a 1961), pode-se afirmar que este papel foi representado pela "arquitetura moderna brasileira".

A Arquitetura Moderna Brasileira aparecia e continua aparecendo, em seus traços mais característicos, marcada por algumas aparentes contradições, das quais a mais visível e decisiva para compreender as peculiaridades da constituição de uma linguagem moderna e ao mesmo tempo brasileira, está na forma particular pela qual se articula a relação entre modernidade e tradição ou, mais precisamente, na equação que se estabelece entre modernidade e construção da identidade nacional. (MARTINS, 2002, p. 374) 


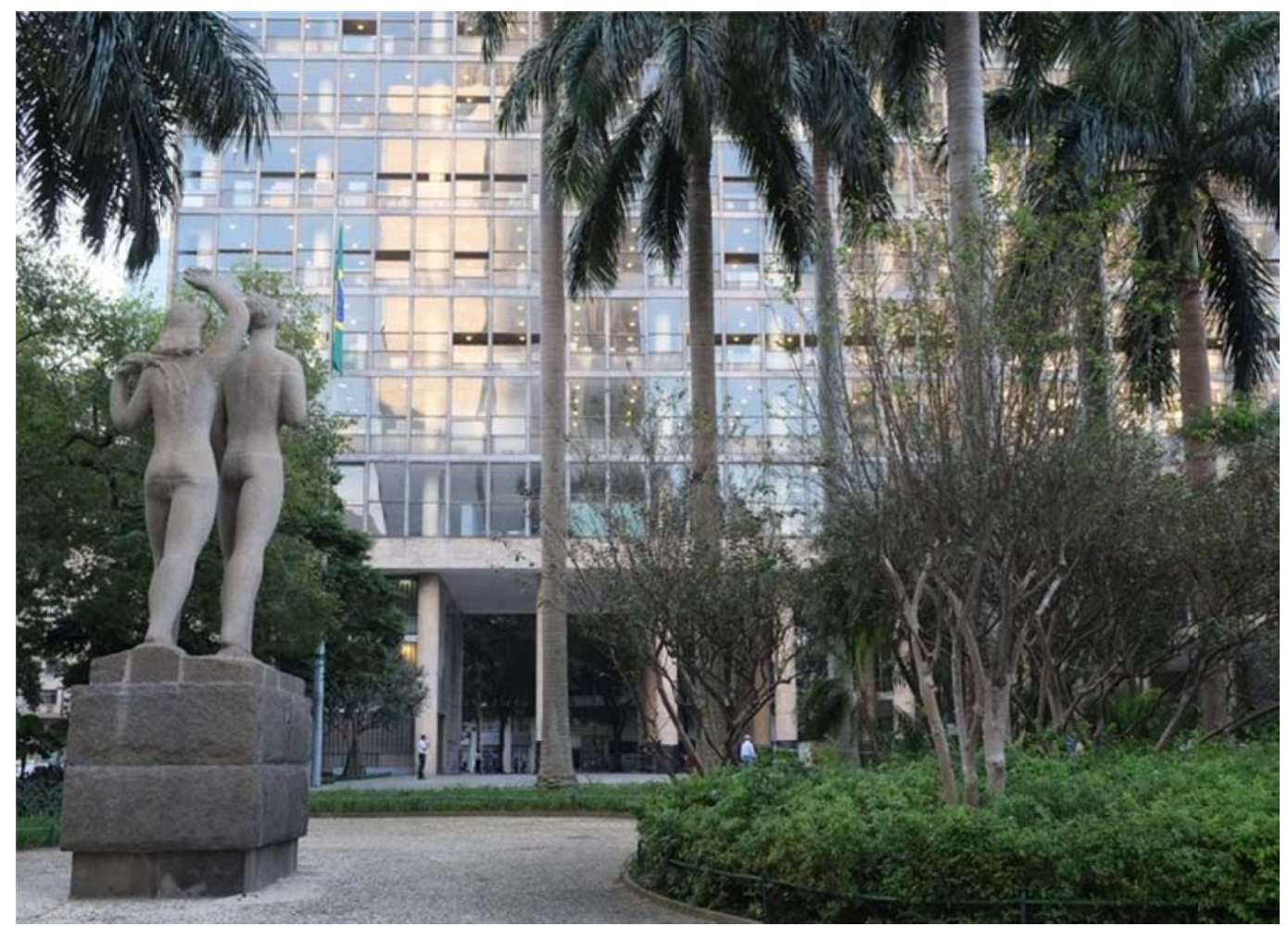

Figura 33: Edifício MES, Rio de Janeiro, 1936-1945. Fonte: Foto de Eduardo Pinha, 2014.

A solução final do edifício do MES afirmava uma noval concepção urbanística ao ocupar o centro do terreno disponível, mostrando uma generosidade com o espaço urbano ao elevar o edifício e recuá-lo em relação às divisas do lote, permitindo a criação de praças e áreas de passeio integradas. Com a arquitetura, os jardins de Burle Marx e os painéis decorativos de Candido Portinari, proporciona uma nova experiência de percurso urbanístico e arquitetônico, sem inviabilizar sua utilização como praça, como mostra a Figura 33. No edifício, o tratamento das fachadas recebeu soluções diferenciadas em função da insolação. Esses elementos trazem leveza à estrutura, monumentalidade e elegância ao conjunto e foram amplamente utilizados em obras posteriores, tornando-se traços marcantes na arquitetura brasileira.

A obra do MES, e as subsequentes, realizadas pelos arquitetos que compunham a equipe do projeto, entre eles, Jorge Moreira, Affonso Eduardo Reidy, Oscar Niemeyer, assim como as obras públicas e residenciais dos irmãos Marcelo e Milton Roberto, encantaram pela novidade e expressão artística na aplicação dos princípios de Le Corbusier, Gropius e Mies Van der Rohe (MINDLIN, 1999, p. 29). Representantes na exposição do MoMA, em Nova York, em 1943, sobre a arquitetura brasileira, que resultou no catálogo "Brazil Builds", obtiveram o reconhecimento externo, mas, principalmente, fizeram com que o país se desse conta de que esta era uma contribuição valiosa à cultura contemporânea. 
A partir daí, o homem comum, desconfiado e irônico por natureza, começou a sentir orgulho de edifícios que a princípio tinha considerado engraçados ou bizarros.

Embora continuasse a tratá-los por apelidos, privilégio do crítico da rua, fazia-o com secreta admiração. Assim, esses edifícios se tornaram parte do profundo orgulho e afeição que os habitantes sentiam por suas cidades. (MINDLIN, 1999, p. 29)

A modernidade brasileira apoiou-se no desenvolvimentismo, num programa definido para um Brasil industrial e urbano, que, iniciado por Getúlio Vargas tem continuidade na política de Kubitschek. A maior diferença reside, no entanto, no lugar que esta ideologia desenvolvimentista confere à cidade, como aponta Laurent Vidal:

Pode-se mesmo dizer que durante o governo Juscelino Kubitschek a cidade conquistou uma segunda vitória sobre o campo, no sentido de que o poder político passou, em maior escala, às mãos da burguesia industrial (...). A partir dos anos 19561960, já não era mais possível reviver - a não ser como anacronismo - a ideologia da "vocação agrária" do Brasil. A indústria, como categoria econômica, política e cultural, passara a dominar o pensamento e a atividade dos governantes e das classes sociais dos centros urbanos grandes e médios. (IANNI, 1979 apud VIDAL, 2009, p. 192)

\subsection{A cidade brasileira, o cinema e o quadro de conflitos ideológicos}

Até o período marcado pela associação do cinema ao movimento arquitetônico e artístico do Art Déco, as salas de exibição do Rio de Janeiro, que já existiam desde o fim do século XIX, testemunharam a evolução espacial no campo da arquitetura, desde as primeiras salas da Rua do Ouvidor ${ }^{29}$ (Figura 34), passando pelo período efervescente da Belle Époque, da Avenida Central e da Cinelândia. Em "A evolução do cinema brasileiro no século XX" (CALDAS e MONTORO, 2006), a citação de Olavo Bilac (1904) mostra como o cinema rapidamente se inseriu na cidade do Rio de Janeiro:

Já há na Avenida Central quatro ou cinco cinematógrafos, e além das casas especialmente destinadas para esses espetáculos, já a mania cinematográfica invadiu todos os teatros e tomou conta de todas as paredes (...). Agora, depois dos fonógrafos da Rua do Ouvidor, os cinematógrafos da Avenida Central... E daqui a pouco não poderemos dar um passo pela cidade, sem encontrar diante dos olhos um desses lençóis alvo em que as cenas da vida humana aparecem deformadas pelo tremor convulsivo da fita, e onde as figuras de homens e mulheres aparecem atacadas de delirium-tremens ou de Coréa, numa trepidação epilética (...) (CALDAS e MONTORO, 2006, p. 30).

${ }^{29}$ Segundo Caldas e Montoro (2006, p. 29), a primeira sala foi inaugurada no número 141 desta rua, em 1897, e chamava-se "Salão de Novidades". 

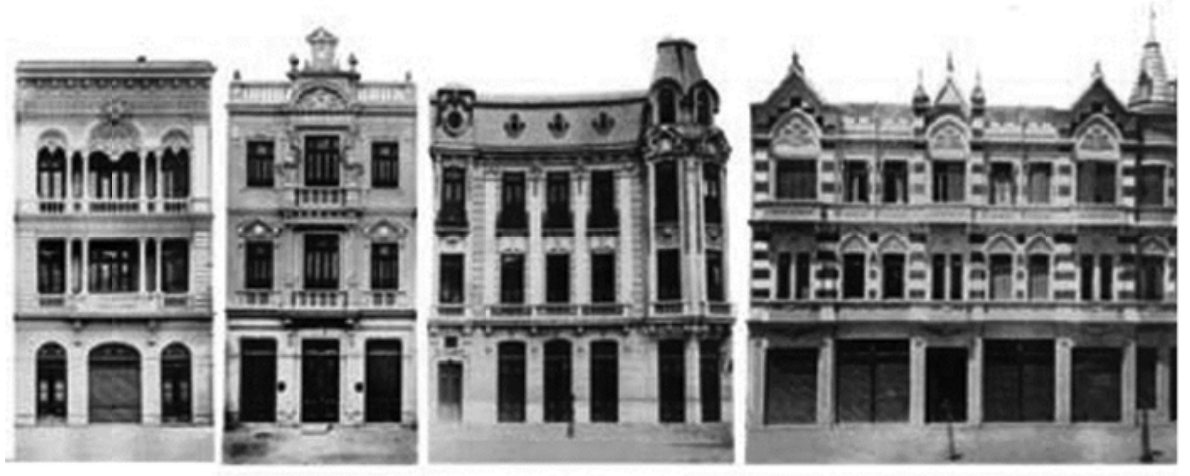

Figura 34: Fachadas de alguns cinematógrafos da Av. Central. No $n^{\circ} 134$, funcionou o Cinema Kosmos, de 1910 a 1911; no $n^{\circ} 116$, o segundo Cinema Pathé, que funcionou até 1940; no ${ }^{\circ}$ 179, funcionou o Cinema Parisiense, onde hoje se encontra o Teatro Glauce Rocha; e, finalmente, nos ${ }^{\text {os }} 151$ e 153, o Cinema Avenida. (Álbum da Avenida Central, de Marc Ferrez. Reprodução de Roberto Jesus Oscar). ${ }^{30}$

O cinema no Brasil não se diferenciava muito do cinema dos outros países nesse primeiro momento e se concentrava em registros da vida cotidiana e urbana. Os filmes resumiam-se às vistas animadas, às atualidades e também a algumas reconstituições de fatos com grande repercussão na imprensa. Na segunda década, por influência da guerra, as películas que estimulavam o sentimento nacionalista começam a ganhar espaço.

"Pátria brasileira" (1917) foi dirigido, numa das cenas patrióticas, por Olavo Bilac. Essa década foi também o tempo da "indiada", segundo Paulo Emilio Salles Gomes e

Adhemar Gonzaga: inúmeras versões de "O Guarany" foram feitas, além de "Iracema e Ubirajara". (AMARAL, 1998, p. 62)

Esse cenário vai se modificando com a entrada dos grandes estúdios e salas de projeção e de um público cada vez maior e com filmes mais longos e ficcionais, mas que davam espaço no início da exibição a pequenos documentários, "cinejornais ${ }^{31 "}$ e filmes de viagem. A cidade era retratada nesses tours urbanos, em seu cotidiano e seus acontecimentos mais importantes.

Eram os noticiários, ou "cinejornais" (o primeiro criado por Charles Pathé, em 1908) que, embora continuassem mostrando o cotidiano da cidade, agora recortavam apenas os fatos mais relevantes; e os filmes de viagem - os travelogues, inventados na

${ }^{30}$ Imagem retirada do artigo de COSTA, Renato da Gama-Rosa. Os cinematógrafos do Rio de Janeiro (1896-1925). Hist. cienc. saúde-Manguinhos, Rio de Janeiro, v. 5, n. 1, junho de 1998. Disponível em http://www.scielo.br/scielo.php?script=sci_arttext\&pid=So104$59701998000100010 \& \operatorname{lng}=$ en\&nrm=iso. Acesso em 5 de março de 2014.

${ }^{31} \mathrm{Um}$ cinejornal é um registro em curta-metragem, seriado, com uma periodicidade semanal para apresentação ilustrada de eventos, exibido no espaço das sessões cinematográficas, antes do longa-metragem. (ARCHANGELO, 2007) 
virada do século pelo americano Burton Holmes, alguns consistindo em tours urbanos. Entre 1911 e 1912, Holmes e sua equipe visitaram o Brasil, filmando cidades como o Rio de Janeiro. (OLIVIERI, 2011, p. 85)

O estilo Art Déco, representado nas figuras 35 e 36, que mostram a fachada do Cinema Pathé Palácio no Rio de Janeiro ${ }^{32}$, foi a imagem e o suporte formal para as grandes salas de cinema a partir dos anos 1930, não só no Brasil. Tanto a arquitetura quanto os filmes nesse período desempenhavam o papel de representar a imagem e a fantasia da cultura moderna, ao mesclar o luxo europeu, o glamour de Hollywood e a modernidade do entreguerras surgida nos Estados Unidos. O ideal da grande cidade moderna, numa apologia do progresso, da máquina e do dinamismo, era constante nos documentários, e começava a mostrar maior envolvimento do cinema com as vanguardas artísticas modernas, que viam o cinema como uma linguagem com grande capacidade de retratar as novas percepções e sensações da vida moderna.

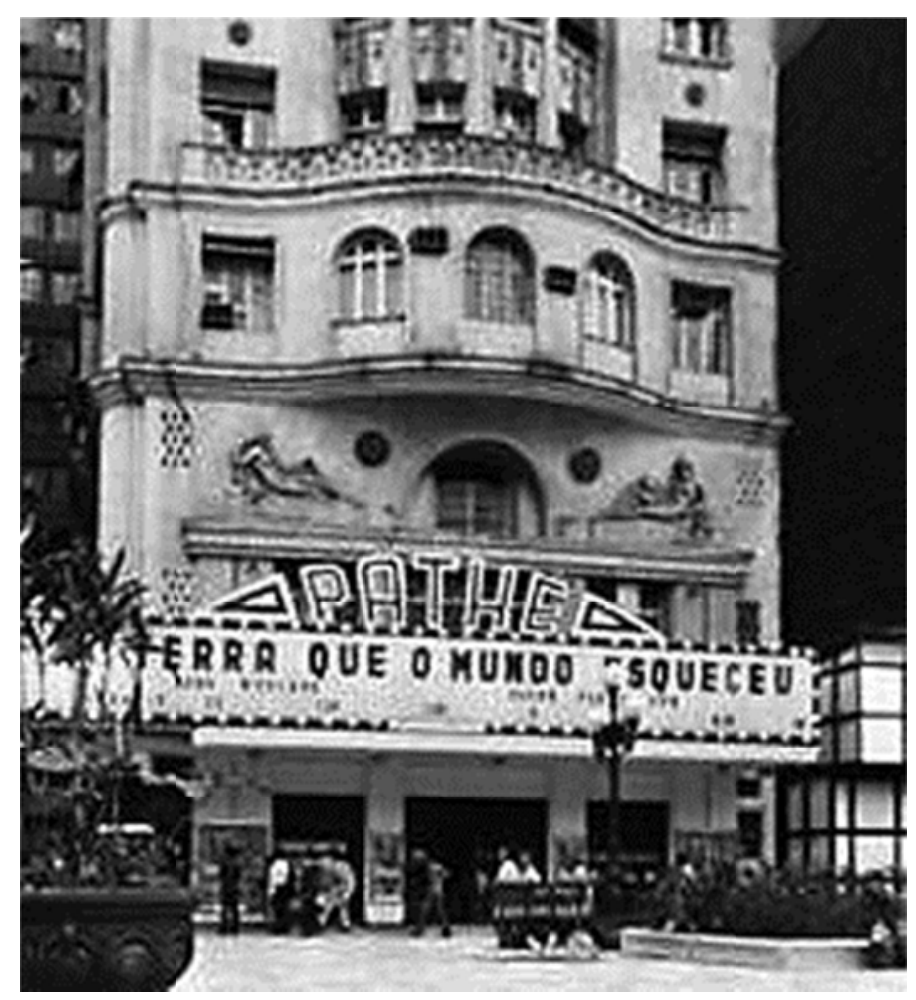

Figura 35: Fachada do Cinema Pathé Palácio, imagens encontradas em diversos sítios de imagens do Rio antigo, mas sem fonte atribuída.

${ }^{32}$ A primeira sala a utilizar a linguagem Art Déco no Rio de Janeiro foi o Cinema Pathé Palácio da Cinelândia, inaugurado em 1928, segundo COSTA, 1999. 


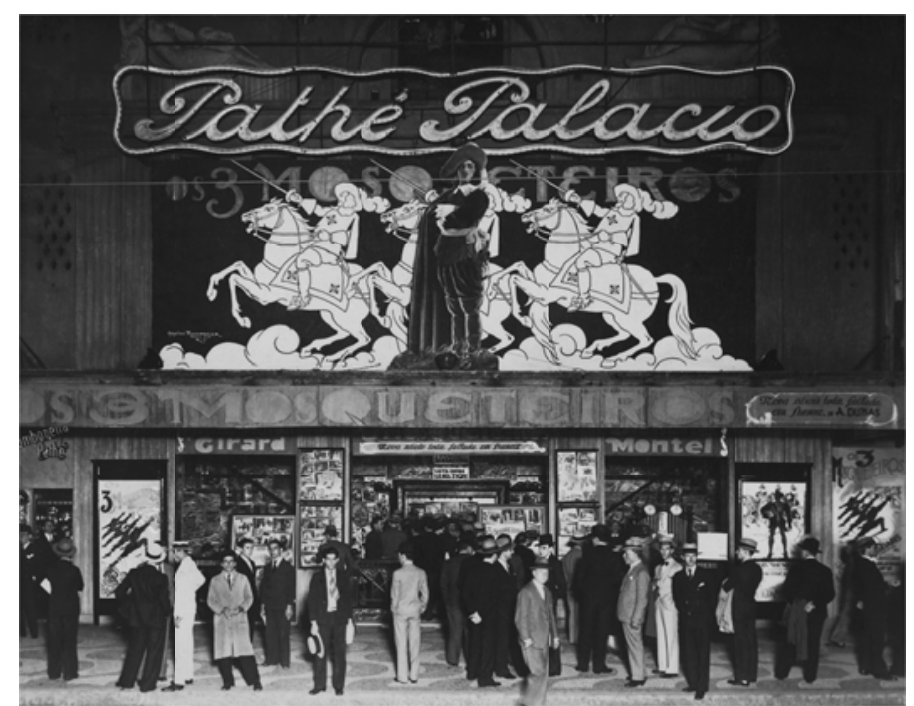

Figura 36: Fachada do cinema Pathé Palácio, com os painéis, letreiros e cartazes de divulgação do filme "Os três mosqueteiros", Rio de Janeiro, 1933. Fonte: Arquivo Nacional RJ. ${ }^{33}$

Entre as "sinfonias urbanas", destaca-se "São Paulo, a symphonia da metrópole" ${ }^{>}$(Figura 37), de Adalberto Kemeny e Rodolpho Rex Lustig (1929), considerado um dos mais importantes documentários urbanos, e seguiu os mesmos princípios das "sinfonias" que surgiram no final da década de 1920 na Europa (OLIVIERI, 2011, p. 89). Procuravam mostrar o cotidiano da cidade como um documento mais social e de um ponto de vista mais próximo ao do habitante da comunidade/cidade retratada.

De um modo geral, os filmes sinfônicos enfatizavam as associaçõies visuais, descrevendo a cidade segundo a dinâmica de seus ritmos e padrões e procurando suas fotogenias, numa progressão temporal que quase sempre ia da alvorada ao crepúsculo. (NICHOLS, 2005, p. 138 apud OLIVIERI, 2011, p. 87).

${ }^{33}$ Imagem retirada do sítio do Arquivo Nacional, disponível em: http://www.exposicoesvirtuais.arquivonacional.gov.br/cgi/cgilua.exe/sys/start.htm?sid= 232 


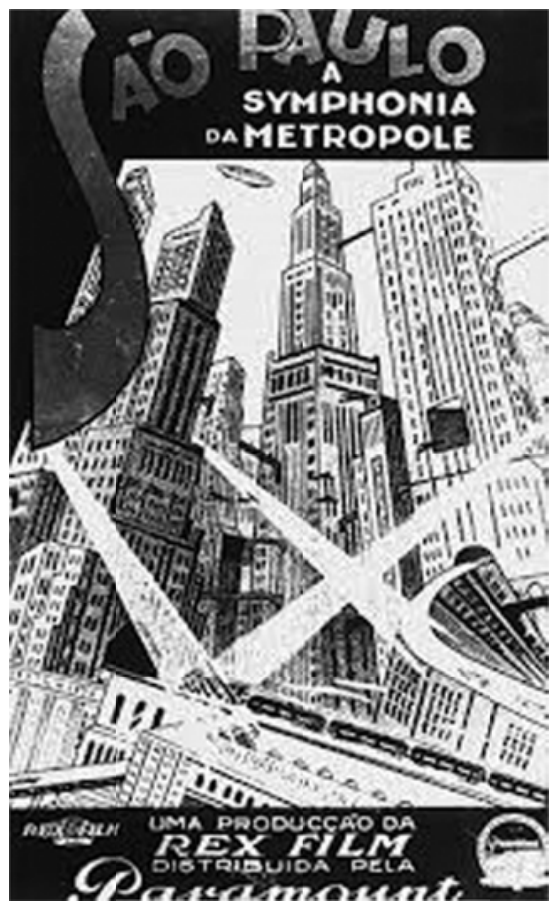

Figura 37: Cartaz de divulgação do filme "São Paulo, a symphonia da metrópole", 1929. Fonte: Cinemateca Brasileira - MinC.

Com uma produção notável do cinema mudo brasileiro, Humberto Mauro, produziu três dos seus filmes entre 1927 e 1929, entre eles o premiado "Thesouro Perdido" (1927), em Cataguases - MG. A sua produção tanto de cinema mudo quanto o cinema sonoro produzido na Cinédia e os documentários realizados para o Instituto Nacional de Cinema Educativo (INCE) colocam-no entre os maiores realizadores brasileiros.

Mesmo distante dos dois grandes centros de produção cultural, Rio e São Paulo, a cidade de Cataguases destaca-se como referência tanto para o cinema (com Humberto Mauro) quanto para a arquitetura moderna presente em diversas residências, colégios, cinema e escritórios -, onde seus principais personagens puderam desenvolver uma admirável contribuição. Paulo Henrique Alonso descreve em seu "Guia da arquitetura modernista de Cataguases" os diversos exemplares desse período:

(...) a cidade se transforma num laboratório modernista. Logo depois vem o projeto do Colégio Cataguases, também de Niemeyer e encomenda da família Peixoto. Seguem-se então inúmeros outros projetos que a elite e a classe média cataguasense encomenda aos mais renomados arquitetos que atuavam no Rio de Janeiro e representavam a vanguarda da arquitetura brasileira daquele momento. Nomes como Carlos Leão, Aldary Toledo, irmãos Roberto, Francisco Bolonha, para citar apenas alguns. Junto aos arquitetos vieram os artistas plásticos, paisagistas e designers de móveis do período: Cândido Portinari, Djanira, Emeric Marcier, Anísio Medeiros, Bruno Giorgi, Jan Zach, Burle Marx, Joaquim Tenreiro, entre outros.

(ALONSO, 2012, p. 10) 
É importante notar que essa arquitetura modernista em Cataguases (Figura 38) se desenvolveu quase que simultaneamente à dos grandes centros urbanos do país como, por exemplo, a construção do conjunto da Pampulha (1942-1944), em Belo Horizonte.

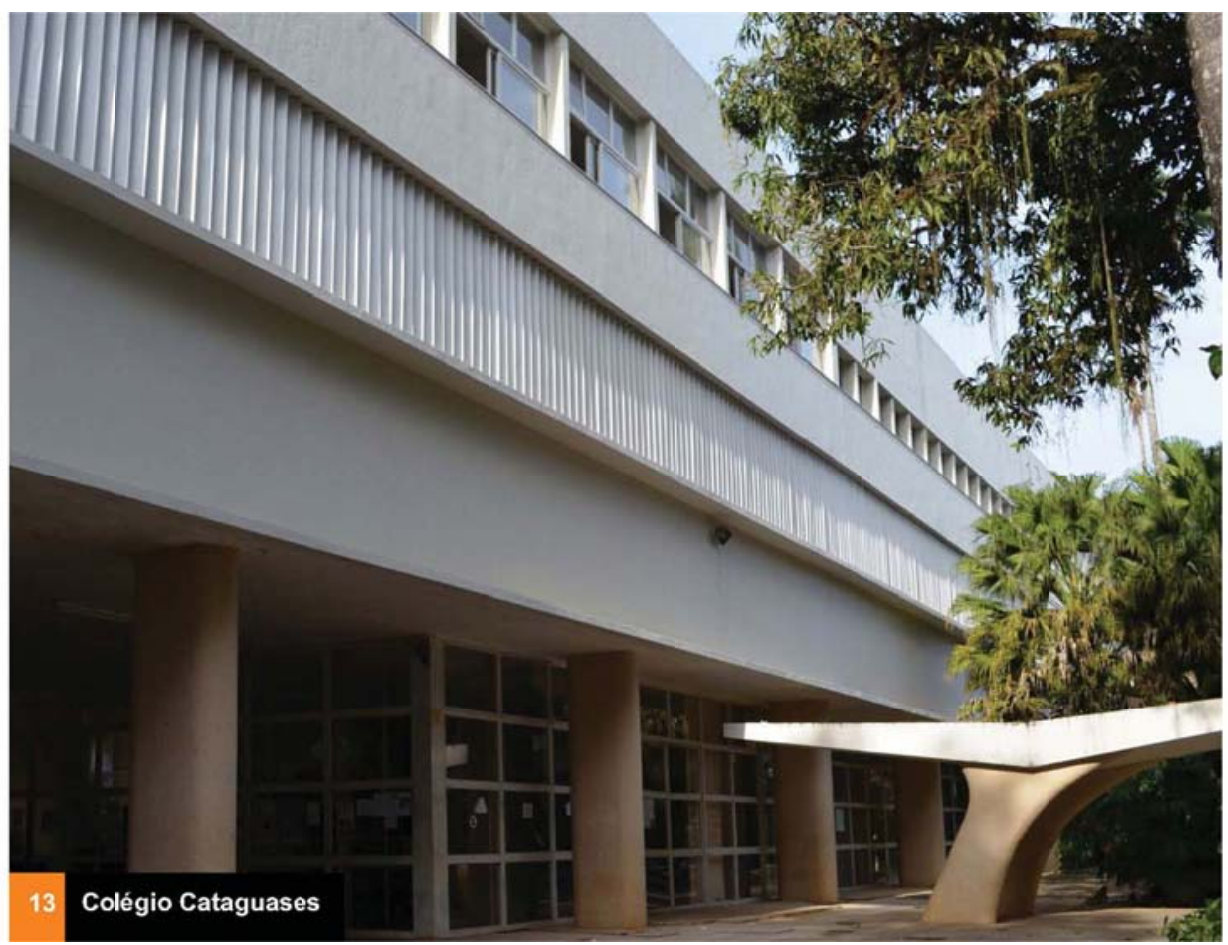

Figura 38: Colégio Cataguases 1945-1949, projeto de Oscar Niemeyer, paisagismo de Burle Marx, painéis de Candido Portinari e Paulo Werneck e mobiliário de Joaquim Tenreiro. Fonte: Guia da Arquitetura Modernista de Cataguases, 2012.

Na década de 1950, o Brasil vivia um momento de desenvolvimento econômico que não se traduzia, no entanto, em desenvolvimento social. Apesar no progresso em alguns setores, a hora da mudança estava no ar. Foi quando o Cinema Novo tomou para si o compromisso de mostrar a realidade das cidades e da população brasileiras.

Diante dessa efervescência política, um grupo de cineastas e intelectuais investiu na criação de uma cultura audiovisual crítica e conscientizadora, onde a técnica e a burocracia da produç̧ão pudessem ser desviadas em direção a uma produção mais livre e mais relacionada com o tempo presente. $\mathrm{O}$ faz a partir das experiências do Cinema Verdade e da Nouvelle Vague, na França, e do Neorrealismo italiano, e uma nova gramática cinematográfica que essas correntes propunham.

Os recursos de captação de som e a inserção de travellings com a câmera sem utilização de tripés introduziram uma nova linguagem, conhecida pela frase "uma câmera na mão, uma ideia na cabeça". $\mathrm{O}$ Cinema Novo proporcionou uma crítica ao discurso dos governantes, uma visão sociológica e ao mesmo tempo subjetiva da realidade brasileira, 
numa proposta consciente que buscava não somente retratar, mas propor meios de superar o subdesenvolvimento ao problematizar o ambiente social do país, tanto rural quanto urbano. (CALDAS e MONTORO, 2006)

Essa produção pode ser classificada em três grandes áreas temáticas ligadas à vida em um país ainda fortemente rural: a escravidão, o misticismo religioso e a violência predominante na região Nordeste. Mais tarde, os cineastas realizam filmes nos quais discutem acontecimentos políticos ocorridos no Brasil, bem como a transformação dos grandes centros urbanos com a modernização do país. (CARVALHO, 2006, p. 292)

Glauber Rocha, um dos principais ativistas do Cinema Novo, e outros artistas naquela década traziam consigo o imperativo da participação no processo político-social, assumindo inteiramente o caráter ideológico do seu trabalho, na intenção de contribuir "para a construção de uma cultura popular; linhas de força que se manifestavam no cinema, na música, no teatro" (XAVIER, 1983, p. 11).

No manifesto que escreveu em 1965, a "Estética da Fome", Rocha defendeu a busca por uma linguagem capaz de traduzir os temas sociais do país, o que se deu, muitas vezes a partir do aproveitamento criativo da precariedade de produção, e pelos temas e paisagens que constituíram um novo imaginário (MONTORO, 2012, p. 81). Xavier (1983, p. 9) também coloca desta maneira: "A carência deixa de ser obstáculo e passa a ser assumida como fator constituinte da obra, elemento que informa a sua estrutura e do qual se extrai a força de expressão".

Ao tratar de temas raros com a crueza da realidade, o Cinema Novo apresenta a violência da fome e da escravidão, a crueldade da política, principalmente em torno do golpe de 1964, a migração dos brasileiros do Nordeste para as grandes capitais, fugindo da seca e da fome. Retratou a complexa e conturbada década de 1960 e suas cidades quando estas experimentavam o inchaço e a segregação. No entanto, havia poesia nisso tudo, pois, imbuídos de um forte desejo de mudança, desejavam um país melhor.

(...) a "estética da fome" faz da fraqueza a sua força, transforma em lance de linguagem o que até então é dado técnico. Coloca em suspenso a escala de valores dada, interroga, questiona a realidade do subdesenvolvimento a partir de sua própria prática. (XAVIER, 1983, p. 9)

Esta questão apresentada na citação de Xavier fica clara na resenha chamada "Poética do Cinema Novo", no qual David Neves, crítico e diretor de cinema, disserta sobre os mais recentes filmes deste grupo. Sobre o filme "Rio, Zona Norte" (Figura 39), de Nelson Pereira dos Santos (1957), escreve:

Rio, Zona Norte confirma com mais secura a tese da unidade e da personalidade ou autoria. O compositor Espírito da Luz Soares é a "voz do povo" e sua vida a nossa 
vida. Eis o samba-na-caixa-de-fósforos, o despojamento, quase o cinema-verdade em 1957. Eis a coragem, a necessidade de utilização da inteligência, do amor ao cinema. Que tipo de universo é esse? A poesia do real, da crueza, do drama, da pobreza, da infelicidade. A poética do Cinema Novo, queiram ou não, é essa aparência, às vezes titubeante, ou a ilusão dessa aparência. Titubeante, na verdade, tem sido o espectador brasileiro que não se entrega facilmente, que reage, que perde a seiva de um mundo novo, em busca de contatos, de relações, de ressonânıcia com uma concepção provinciana e alienada que traz consigo. ${ }^{34}$

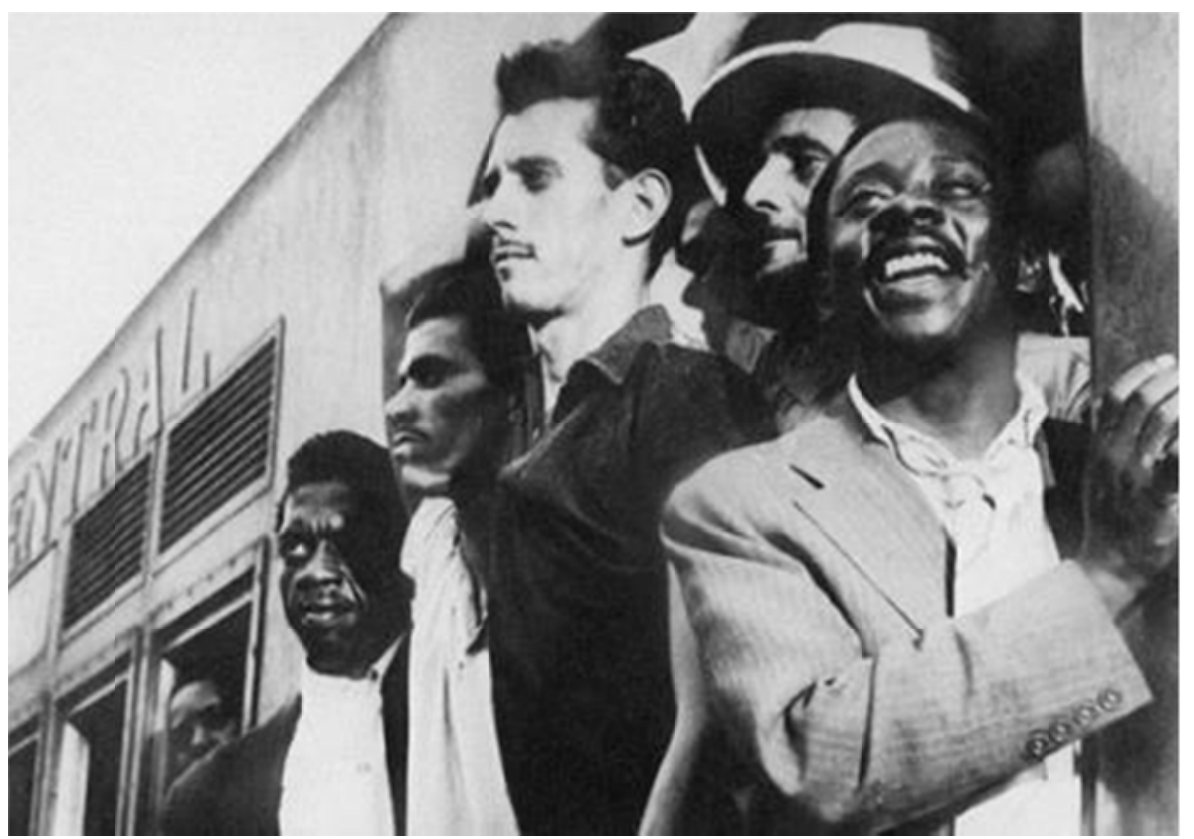

Figura 39: Cena do filme "Rio, Zona Norte", de Nelson Pereira dos Santos, 1957. Fonte: http://cineola.wordpress.com, acesso em 08.08.2013.

\section{O interesse do Cinema Novo pela dimensão histórica dos} acontecimentos é registrado também na sua produção de cinema documentário, em sua maior parte de curta-metragem. Com "Garrincha, alegria do povo" (Joaquim Pedro de Andrade, 1962), o futebol é tratado pelo seu mito de "desesperada alegria do povo brasileiro" ao que, de acordo com Glauber Rocha (apud CARVALHO, 2006, p. 2.95), representa na verdade, uma fuga dos dramas cotidianos.

Os documentários brasileiros eram dominados até a década de 1970 por um modelo sociológico característico ao se distanciar da cena e dos personagens utilizando um tom autoritário de seus comentários em off ${ }^{35}$,

34 "Poética do Cinema Novo", David Neves, 1965. Forma revisada do trabalho apresentado, em Gênova, em janeiro de 1965, na V Resenha do Cinema Latinoamericano. Fonte: http://www.contracampo.com.br/39/cinemanovonobrasil.htm, acesso em 08.08.2013.

${ }^{35} \mathrm{O}$ narrador não está presente na ação. Muito utilizado nos documentários e cinejornais, o recurso possibilita que possam ser adicionadas narrações e comentários durante a montagem e sem a necessidade de captação de som direto no momento da 
como percebido pelo cineasta e historiador Jean-Claude Bernardet e retomado por Olivieri:

Na metade final da década (de 1960), a produção é dominada pelo que Jean-Claude Bernardet denominou de "modelo sociológico", caracterizado por entrevistas com as personagens (supostamente sem interferência da filmagem), intercaladas por um comentário em off informativo-expositivo e ideológico, a "voz do saber", que se colocava como a "dona da verdade". (OLIVIERI, 2011, p. 100)

A razão dessa característica acontece grande parte em decorrência do estabelecimento de um regime militar ditatorial que toma o governo pelo golpe de estado em 1964, instaurando a censura aos meios de comunicação e usando de violenta repressão política, especialmente no final da década de 1960 e ao longo dos anos 1970, justificada pela necessidade de manter a estabilidade política e a segurança interna.

$O$ golpe militar e a censura ${ }^{36}$ inviabilizaram e desestruturaram o projeto original do movimento de "discutir o Brasil abertamente, enfatizando segmentos sociais sem direito a voz, com a proximidade da câmera na mão, do som direto, da ida dos cineastas aos locais onde o real seria enquadrado." (CARVALHO, 2006, p. 298). Aos poucos os cineastas começam a encontrar brechas para retomar a produção e neste momento se dão conta de que "seus filmes não tinham força nem poder para transformar a realidade como chegaram a crer" (idem, p. 298). Carvalho reconhece em "A grande cidade" (Carlos Diegues, 1966) uma proposta de recomeço, ao basear-se no que já havia sido feito para apontar novas direções ao Cinema Novo, aliado ao sucesso de bilheteria que o filme alcançou.

A instauração do AI-5 no final de 1968, que apertou o cerco da censura, e uma explícita ditadura no Brasil, instituiu uma necessidade de camuflagem, afastando a temática do Cinema Novo das questões políticas e sociais. Esta camuflagem fica visível na produção de Glauber Rocha, e Maria do Socorro Carvalho (2006), a identifica como a falta de clareza de um inimigo:

filmagem. Isso se devia principalmente pela precariedade da tecnologia de captação de som e sincronização.

${ }^{36} \mathrm{O}$ “Ato Institucional n ${ }^{\circ} 5$ " (AI-5), baixado em 13 de dezembro de 1968, durante o governo do general Costa e Silva, foi a expressão mais acabada da ditadura militar brasileira (1964-1985). Autorizava o presidente da República, em caráter excepcional a: decretar o recesso do Congresso Nacional; intervir nos estados e municípios; cassar mandatos parlamentares; suspender, por dez anos, os direitos políticos de qualquer cidadão; entre outras medidas. No preâmbulo do ato, dizia-se ser essa uma necessidade para atingir os objetivos da revolução, "com vistas a encontrar os meios indispensáveis para a obra de reconstrução econômica, financeira e moral do país". Fonte: CPDOC FGV, http://cpdoc.fgv.br/producao/dossies/FatosImagens/AI5, acesso em 28/03/2014. 
No retorno de Antônio das Mortes ao sertão da Bahia, em "O dragão da maldade contra o santo guerreiro”, explicita-se outra leitura dos problemas sociais brasileiros, bastante diversa daquela vista em "Deus e o diabo na terra do sol" cinco anos antes. Trazendo à tona novamente seus personagens do passado - místicos, cangaceiros, coronéis -, Glauber Rocha agora diria não haver traços definidos entre Deus e o diabo, entre o bem e o mal, como também não haveria uma agente deflagrador da utópica "revolução", que o inimigo não é um, e sim vários e mutáveis. (CARVALHO, 2006, p. 305)

A partir da década de 1970, quando a abertura democrática se iniciava, o modelo sociológico que dominava a linguagem dos documentários brasileiros sofreu uma mudança substantiva e o documentário começou a dar lugar à possibilidade de mostrar a cidade "por dentro".

O filme "Lacrimosa" (Aloysio Raulino e Luna Alkalay, 1970) é um exemplo da superação deste modelo e Olivieri (2011) destaca a cena de um longo travelling de dentro de um carro percorrendo a Marginal Tietê, via expressa recém- inaugurada em São Paulo e que termina mergulhando numa favela:

O que podemos ver nesse travelling magistral? Inicialmente, paredes. Depois vemos algumas plantas acidentais, um solo castigado, uma paisagem quase árida e certamente inóspita. Mais adiante, alguns indícios de vida humana: grandes construções e fachadas de fábricas nos mostram uma São Paulo industrial, geométrica. Um close, entretanto, revela ao longe uma selva urbana dominada por prédios enormes, símbolos da grandeza e da riqueza da maior cidade do país. A câmera desfaz o close e volta para a Marginal. Na beira da avenida, não vemos mais fábricas. Vemos, sim, pessoas habitando precárias construções de madeira, que mal se poderia chamar de favela, uma zona árida e inóspita semelhante à que víamos antes. Travelling terminado, os cineastas — como que não acreditando — vão a essa localidade. Filmam crianças: pés no chão, dedos sujos na boca, rosto às vezes já danificado pelas condições miseráveis de vida. Sim, a Marginal é um microcosmo da cidade. E "Lacrimosa" uma pequena radiografia de São Paulo. (GARDNIER apud OLIVIERI, 2011, p. 102)

É possível relacionar as cenas da construção de Brasília e a vida de seus operários que num primeiro momento vinham ao encontro desse tipo de linguagem, porém este modelo sociológico já apresentava modificações quando, em 1967, o cinemanovista Joaquim Pedro de Andrade filma "Brasília, contradições de uma cidade nova", e os contrastes da realidade social da capital recém-inaugurada. 
De acordo com o que foi exposto neste capítulo, pode se observar que as diversas experimentações artísticas ocorridas no Brasil, ressaltando o período após 1920, inauguram a busca e a representação de um desejo de modernidade. Percebe-se o aguçamento da percepção da realidade local a partir da observação e vivência da modernidade europeia, que acabam por traduzir-se em espírito de brasilidade. Nesse sentido, o modernismo, além do papel estético, representou um estado de espírito revolucionário, promoveu sistematizações e investigações que preparariam o campo para outras manifestações.

Ao analisar a vanguarda brasileira evidenciaram-se as diferenças com relação à vanguarda europeia, assim como alguns acontecimentos anacrônicos resultantes da influência que esta exerceu no Brasil, país que iniciava sua modernização.

No período de forte desenvolvimento econômico, nas décadas de $195^{\circ}$ e 1960, os movimentos concretistas resgatam o contato com a vanguarda europeia e avançam no sentido de uma arte mais relacionada com a realidade diante de um quadro de conflitos sociais. Pela atitude questionadora e libertária, almejavam intervir na produção industrial com o objetivo de uma transformação social, utilizando ferramentas de comunicação de massa, aumentando a difusão e aproximando a arte da realidade.

A mesma contenda estava presente na luta de Glauber Rocha e do grupo do Cinema Novo em mostrar ao Brasil a sua própria realidade, diferentemente do discurso desenvolvimentista do governo. Segundo Montoro (2012, p. 194), Brasília aconteceu ao mesmo momento em que ocorria a "explosão do movimento do Cinema Novo que invadiu nossas salas e reconfigurou a imagem dos brasileiros e da paisagem nacional", ao mostrar a vida nas grandes cidades brasileiras, a expansão das favelas e as grandes massas de migrantes que procuravam nas cidades um meio de sobrevivência. As manifestações artísticas nesse período, como o Cinema Novo e a arte de Oiticica, por exemplo, mostraram a realidade das cidades brasileiras, como tema, cenário ou enredo.

Em meio a um período de conflitos ideológicos sobre questões urbanas, o Brasil projetava-se no mundo como um país de grandes iniciativas e a construção de uma nova capital vinha de encontro com o projeto político de modernidade, apoiado na indústria e na cidade, que dependia de uma urbanização difundida no conjunto do território e que reforçasse o caráter nacionalista. Ao lançar mão dos elementos simbólicos oferecidos pela arquitetura moderna e sua "brasilidade", a construção da nova capital, Brasília, deu um novo impulso aos debates sobre a urbanização e modernização brasileira, envolvendo tanto o cinema quanto outras formas de expressão artística e os meios de comunicação. 


\section{Brasília, nos eixos e vias}

Inaugurada em 196o, Brasília incorporou o ideário do urbanismo moderno, expresso na "Carta de Atenas" de 1933. Presente em todos os projetos que concorreram à seleção do Plano Piloto de Brasília, a inspiração do urbanismo funcionalista traçaria certamente o destino da nova capital do país. No entanto, percebe-se que Brasília incorporou também outras fontes: Carpintero (1998, p. 125) destaca a "estrutura linear proposta por Soria y Mata, em 1882, a cidade-jardim, de Howard, de 1898, as técnicas rodoviárias desenvolvidas na Alemanha e nos Estados Unidos na década de 20, além da evolução dos instrumentos jurídicos de propriedade".

\footnotetext{
O caráter funcional comparece em todos (os projetos que concorreram ao edital) e está como que entranhado na cultura brasileira. Todos definem, de modo mais ou menos direto, zonas específicas, e talvez não fosse mesmo possível pensar uma cidade, àquela época, sem usar tal recurso. Todos, entretanto, apontam para as mesmas raízes positivistas do início do século XIX, uns pela via racionalista, formal ou funcional, outros pelas vias orgânicas. (CARPINTERO, 1998, p. 110)
}

Para que a construção de Brasília não seja entendida somente como o conjunto de vias e edifícios que a compõem, mas como uma construção teórica, já vimos até aqui as diversas teorias urbanísticas que vão constituir um corpus teórico e simbólico que vai se materializar nas propostas do urbanismo modernista e notadamente em Brasília. Adiciona-se também ao Plano de Lucio Costa e seus antecedentes, as inúmeras modificações que Brasília sofreu durante sua construção e vem sofrendo em sua consolidação, pelos mais diversos agentes.

A paisagem natural da capital se dá pela presença do Lago Paranoá, artificialmente criado a partir de uma barragem, com o formato de dois braços que literalmente "abraçam" o triângulo que inscreve o Plano Piloto. A declividade do terreno, as escarpas próximas ao lago, conformam uma paisagem "de grande força, conferindo monumentalidade ao sítio, apenas pela localização". (CARPINTERO, 1998, p. 6o) 


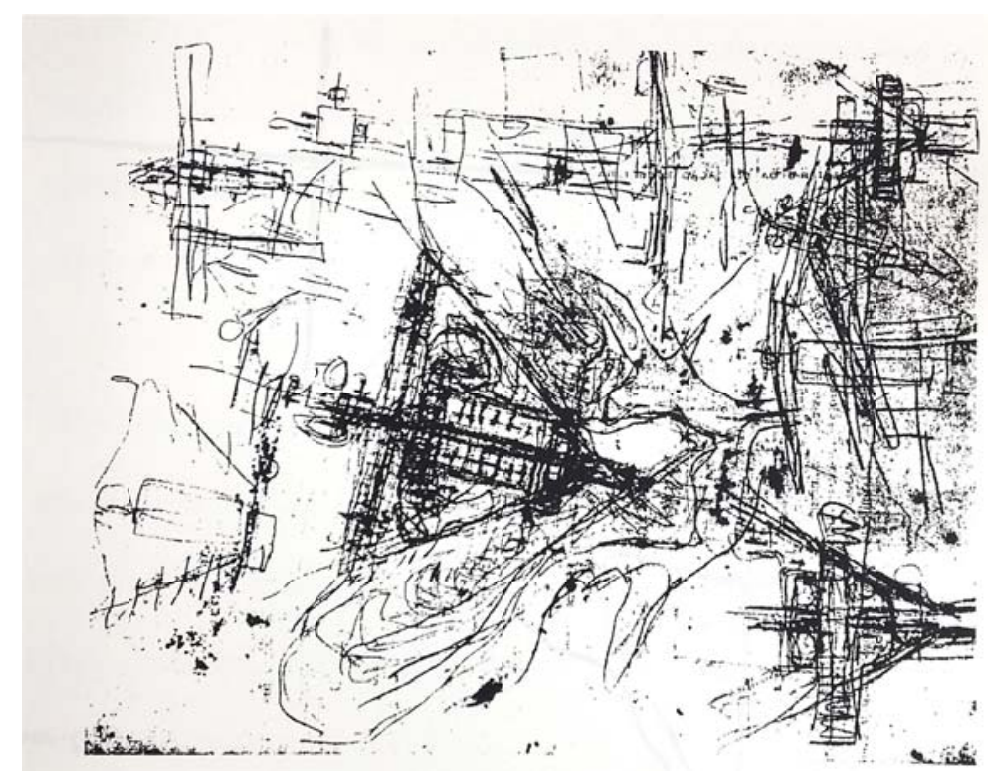

Figura 4o: Esboços do projeto de Lucio Costa. Fonte: CARPINTERO, 1998.

A nobreza natural do seu sítio foi percebida pela sensibilidade de Lucio Costa, que tirou daí partido para o seu projeto, composto de dois eixos em forma de cruz. "Procurou-se depois a adaptação à topografia local, ao escoamento natural das águas, a melhor orientação, arqueandose um dos eixos a fim de contê-lo no triângulo que define a área urbanizada". (COSTA, 1995)

Brasília, que "nasceu do gesto primário de quem assinala um lugar ou dele toma posse: dois eixos cruzando-se em ângulo reto, ou seja, o próprio sinal da cruz" (COSTA, 1995, p. 285) no Plano Piloto de Lucio Costa, e dessa maneira fez "manifestar-se o espírito de lugar" (CARPINTERO, 1998, p. 123), os eixos definiriam a forma e os percursos da cidade e para a cidade (Figura 41).

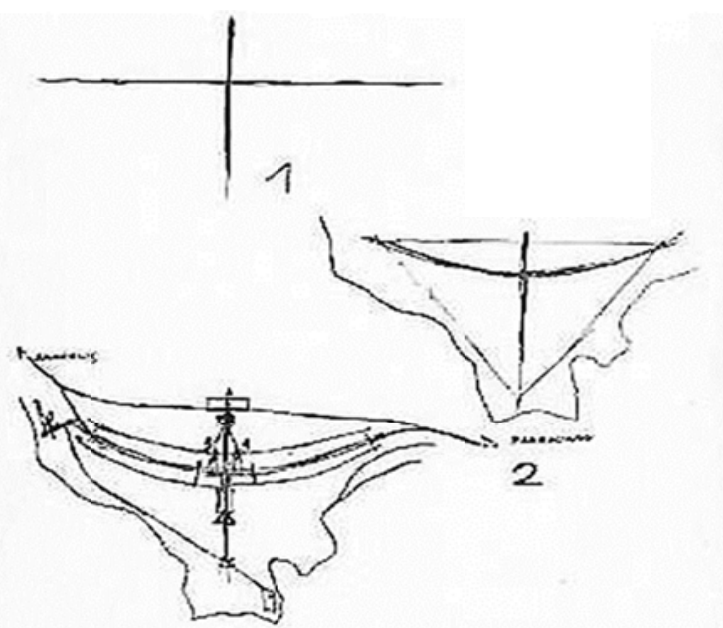

Figura 41. Memória descritiva do Plano Piloto de Brasília. Lucio Costa, 1957. Fonte: COSTA, 1995 . 
Ao constituir no centro do país um ponto de conexão através de estradas, aeroportos e ferrovias, a presença da capital provocou crescimento e surgimento de cidades na região, funcionando como indutora do processo de crescimento urbano, mas ao mesmo tempo consequência de um processo que já estava em curso - a urbanização do território, concentração nas metrópoles, aumento da malha viária - desde os anos 1930.

É evidente que o compromisso de JK com a mudança da Capital Federal articulava-se aos demais objetivos de sua política: a interiorização da ocupação do país, o desenvolvimento industrial - baseado na indústria automobilística - tanto que Brasília foi definida a meta-síntese de seu plano de governo. (CARPINTERO, 1998, p. 70)

Ao estabelecer a estrutura geral da cidade, Lucio Costa deixa evidente que seu principal elemento de organização seria o veículo individual: "Representou o papel de vitrine da política governamental de promover o desenvolvimento nacional com suporte na implantação da indústria de veículos automotores - e, como consequência, a indústria petrolífera" (CARPINTERO, 1998, p. 145). No memorial descritivo do Plano Piloto, "traz inúmeras referências ao automóvel individual, poucas aos transportes coletivos, e aos veículos de carga" (idem, p. 144).

E houve o propósito de aplicar os princípios francos da técnica rodoviária - inclusive a eliminação dos cruzamentos - à técnica urbanística, conferindo-se ao eixo arqueado correspondente às vias naturais de acesso à função circulatória tronco, com pistas centrais de velocidade e pistas laterais para o tráfego local. (COSTA, 1995)

Brasília é conhecida e representada frequentemente pelos seus dois eixos principais e perpendiculares. Eles setorizam as funções da cidade e as paisagens visíveis ao percorrê-los são completamente diferentes. Carpintero chama a atenção deste ponto, fazendo uma relação com a "Cidade Linear" de Soria, com a diferença de que em Brasília existem duas cidades lineares que se cruzam.

Saboia em "O vazio moderno e o reconhecimento de paisagens culturais: O caso da rodoviária em Brasília” (2010) destaca que o Plano Piloto de 1957 é compreendido através da análise do cruzamento entre duas paisagens: a monumental e a residencial.

\footnotetext{
A primeira, Monumental, possui hierarquia natural, com praças nos amplos gramados entre as vias do eixo - em um caráter non-aedificandi e livre -, que definem a estrutura governamental e sua a dimensão perene e simbólica da capital. A segunda paisagem, presente na escala cotidiana da cidade, é composta pelas superquadras e edifícios residenciais de gabarito uniforme sob pilotis, 'emoldurados por uma larga cinta densamente arborizada' como descreve o memorial de 1957. O percurso ao longo da cidade-parque pelo eixo sul se estende até a plataforma da Rodoviária, onde o tráfego submerge pelo túnel de nível inferior e segue livremente pelo eixo norte da cidade. (SABOIA, 2010)
} 
A ideia de "conciliar as velocidades naturais, do pedestre ou do cavalo, com as velocidades mecânicas dos automóveis, bondes, caminhões ou ônibus" (Le Corbusier, 1993) foi materializada em Brasília ao separar a cidade em setores residenciais, comerciais, governamental, entre outros, constituindo vias de circulação independentes: veículos e pedestres com fluxos autônomos configurados a partir de passagens de níveis, vias sem cruzamentos e tráfego livre que propiciam a liberação do solo pela elevação dos edifícios em pilotis para o livre circular do pedestre. Os deslocamentos de veículos em eixos retilíneos enquadram paisagens que se repetem em ritmo contínuo, vislumbram seus espaços planejados, verdes, vazios, em uma rede de circulação hierárquica que resulta numa maneira peculiar de percorrer a cidade.

Assim, nesse capítulo, Brasília será percorrida, tanto pela narrativa das experiências dos percursos cotidianos, tanto pelas narrativas captadas e transmitidas pelo cinema.

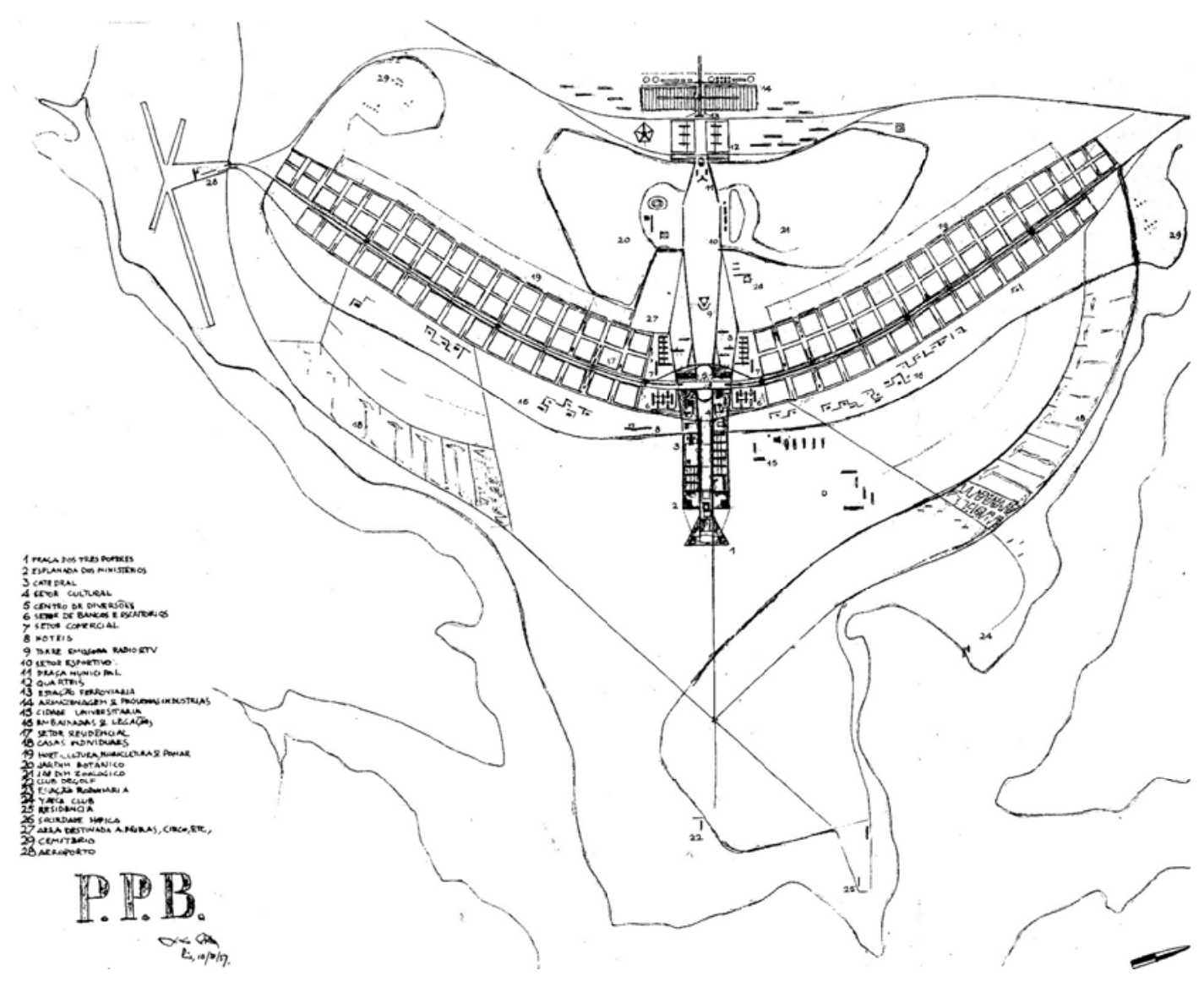

Figura 42: Plano Piloto de Brasília, Lucio Costa. Fonte: COSTA, 1995. 


\subsection{Percorrer Brasília}

O eixo monumental, composto de quatro terraplenos, compõe a paisagem cívica da capital e sua monumentalidade se dá pela escala de seu gramado central, um grande vazio emoldurado pelos edifícios que $o$ margeiam (Figura 43 e 44), mas também pelo trajeto proposto para os automóveis, quando o motorista pode visualizar a repetição dos blocos dos ministérios de ambos os lados e as torres do congresso no centro da perspectiva. A Praça dos Três Poderes, por se localizar em nível mais baixo, só é visualizada ao se chegar ao final do último terrapleno, quando então é obrigatório percorrê-la, o que possibilita visualizar os três palácios que a compõem.
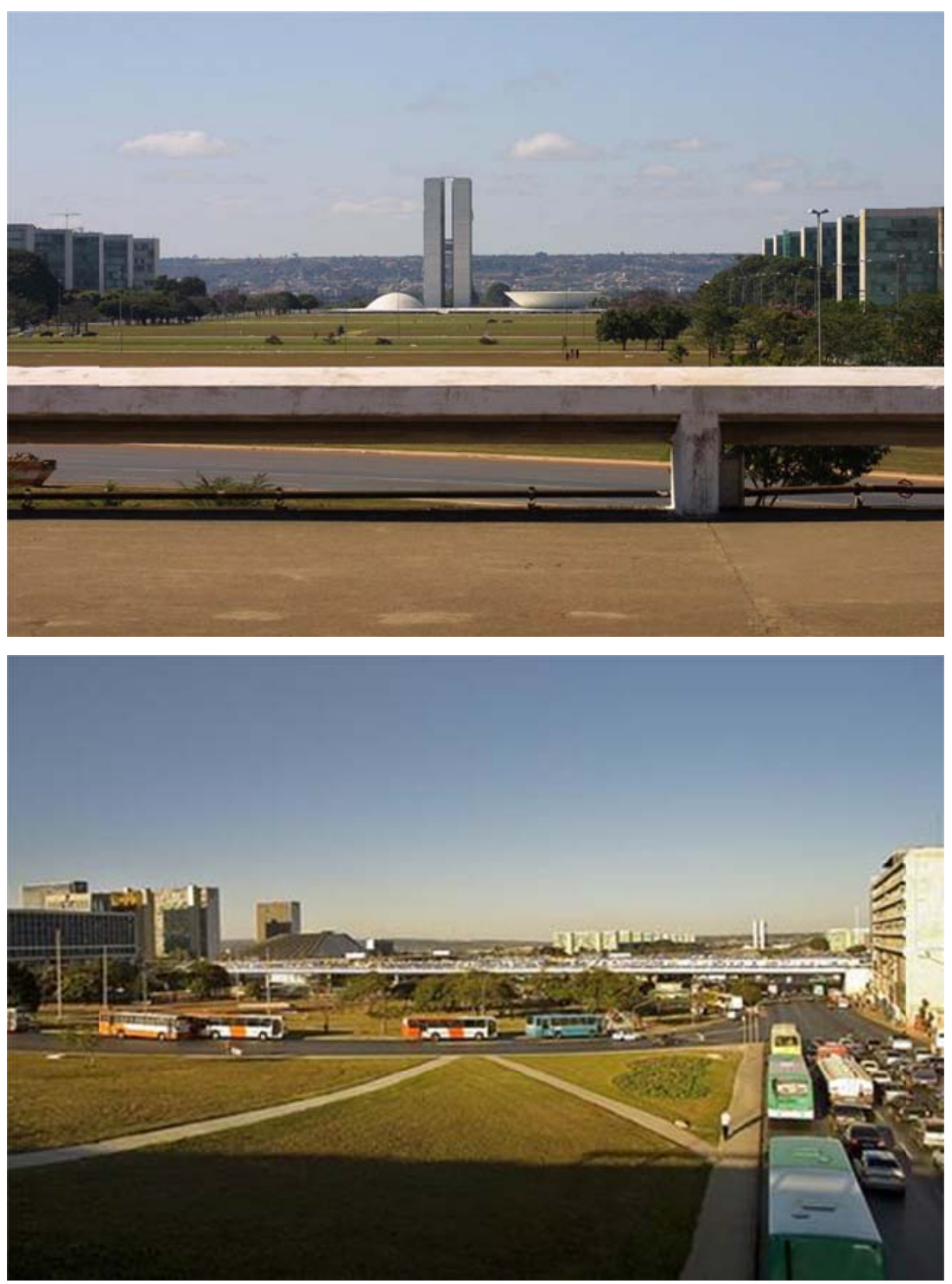

Figura 43 e Figura 44: vistas do eixo monumental. Fotos: Cleber Figueredo, 2006 
O eixo rodoviário, arqueado, compõe as asas e abriga os fluxos cotidianos de residência e comércio de norte a sul. Seu arqueamento possibilitou a melhor adaptação às curvas de nível "na melhor técnica rodoviária". É percorrido em velocidade correspondente à de rodovias por uma paisagem arborizada, interrompida por edifícios em gabarito uniforme e por amplas áreas gramadas (

Figura 45 e 46), no que Carpintero (1998, p. 123) chama de "habitações organizadas em esquemas evoluídos da cidade-jardim, as superquadras". $\mathrm{O}$ acesso às quadras residenciais se dá por meio de trevos completos, sem cruzamento ou impedimento de fluxo, através de vias de comércio locais. No interior das quadras, as vias de acesso de veículos continuam separadas das vias de pedestres.
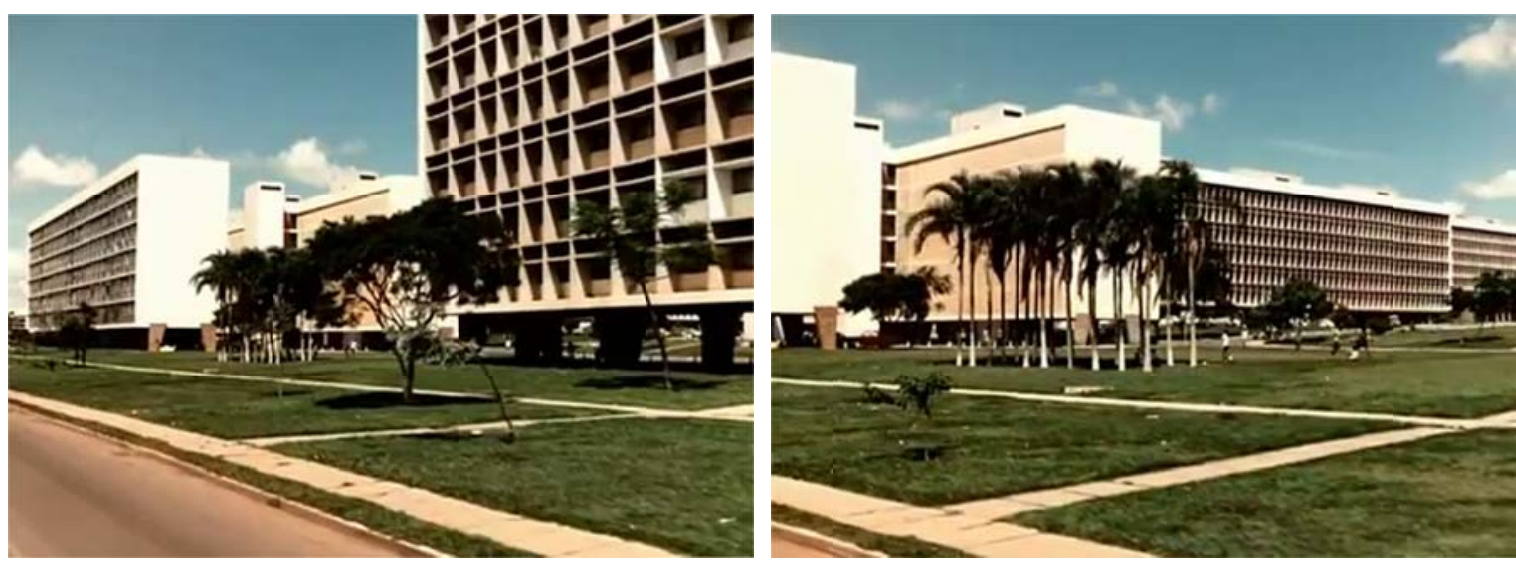

Figura 45 e Figura 46: Stills do filme "Brasília, contradições de uma cidade nova", de Joaquim Pedro de Andrade, 1967.

No interior das superquadras (Figura 47 e Figura 48), o pedestre tem o terreno livre para circulação em decorrência da elevação dos edifícios em pilotis e pode escolher o melhor trajeto, percorrendo por calçadas pavimentadas ou através de caminhos trilhados nas extensas áreas verdes. Esta última, resultando numa experiência única e talvez improvável, se analisada do ponto de vista dos hábitos e condicionamentos do pedestre, que a princípio busca o percurso pavimentado e seguro para caminhar. Do ponto de vista do automóvel, a circulação no interior da superquadra se dá através de uma única entrada/saída de acesso, ficando assim restrito a moradores e/ou visitantes, já que a via interna não tem nenhuma outra ligação com vias externas e sua única função é garantir acesso aos blocos de apartamentos e estacionamentos. 

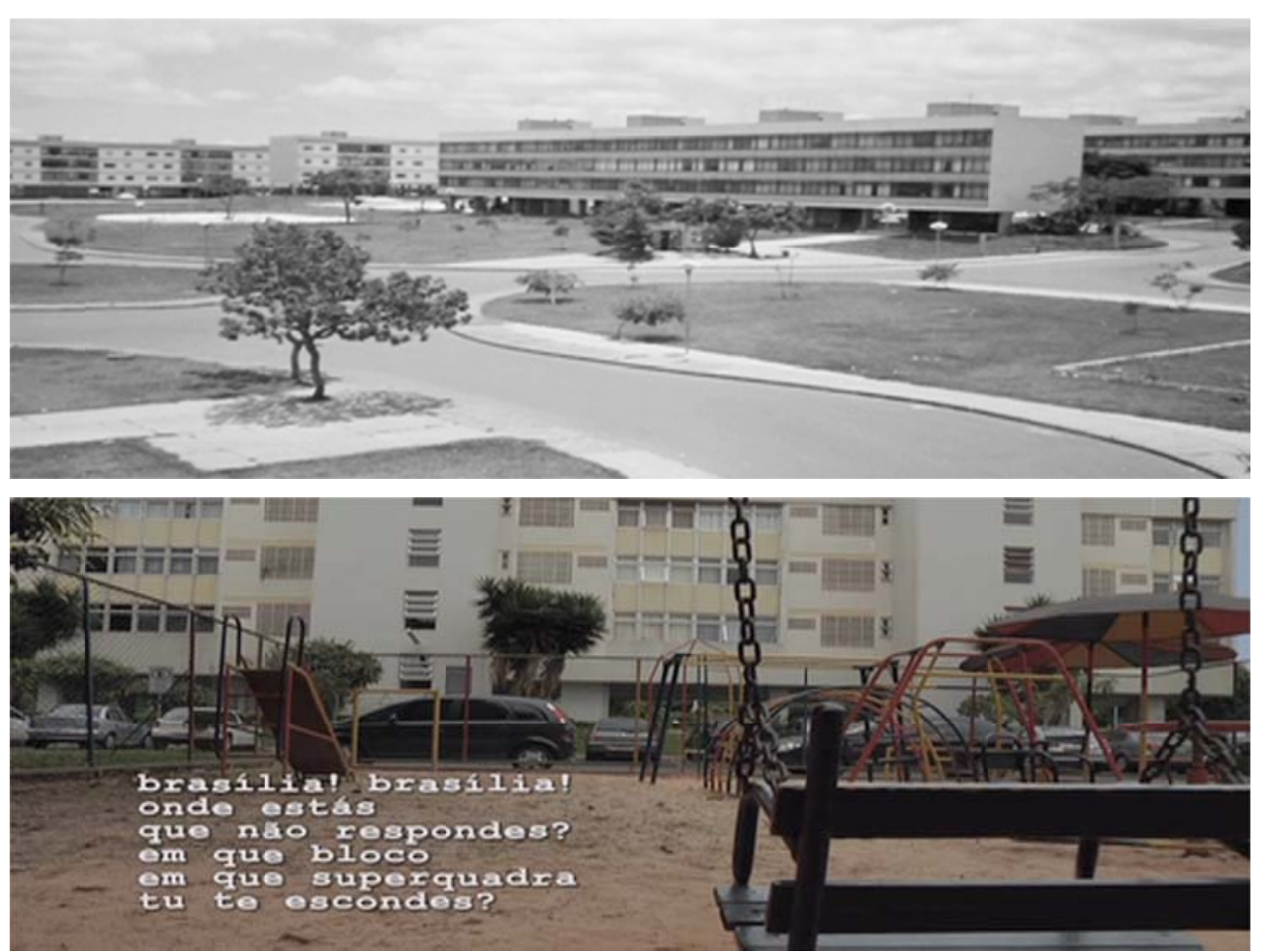

Figura 47 e Figura 48: Stills do filme "Braxília", de Danyella Proença, 2010.

Para Carpintero (1998, p. 148), a "monumentalização do automóvel implicou num confinamento do pedestre". Observando as superquadras e suas possíveis ligações, ao caminhar percebem-se frequentes obstáculos ou barreiras a transpor. $\mathrm{O}$ caminho de pedestres que conttorna cada superquadra nem sempre oferece continuidade.

Exatamente no cruzamento dos dois eixos, localiza-se a plataforma da rodoviária (Figura 49 e Figura 5o): um viaduto de 200 metros de largura que abriga amplos espaços de fluxos de pedestres e veículos.

Previram-se igualmente nessa extensa plataforma, destinada, como no piso térreo, ao estacionamento de automóveis, duas amplas praças privativas dos pedestres, uma fronteira ao teatro da Ópera e outra, simetricamente disposta em frente a um pavilhão de pouca altura destinado a restaurantes, bar e casa de chá. Nestas praças o piso das pistas de rolamento, sempre de sentido único, foi ligeiramente sobrelevado em larga extensão, para livre cruzamento dos pedestres num e noutro sentido, o que permitira acesso franco e direto tanto dos setores do varejo comercial quanto do setor dos bancos e escritórios. (COSTA, 1995) 


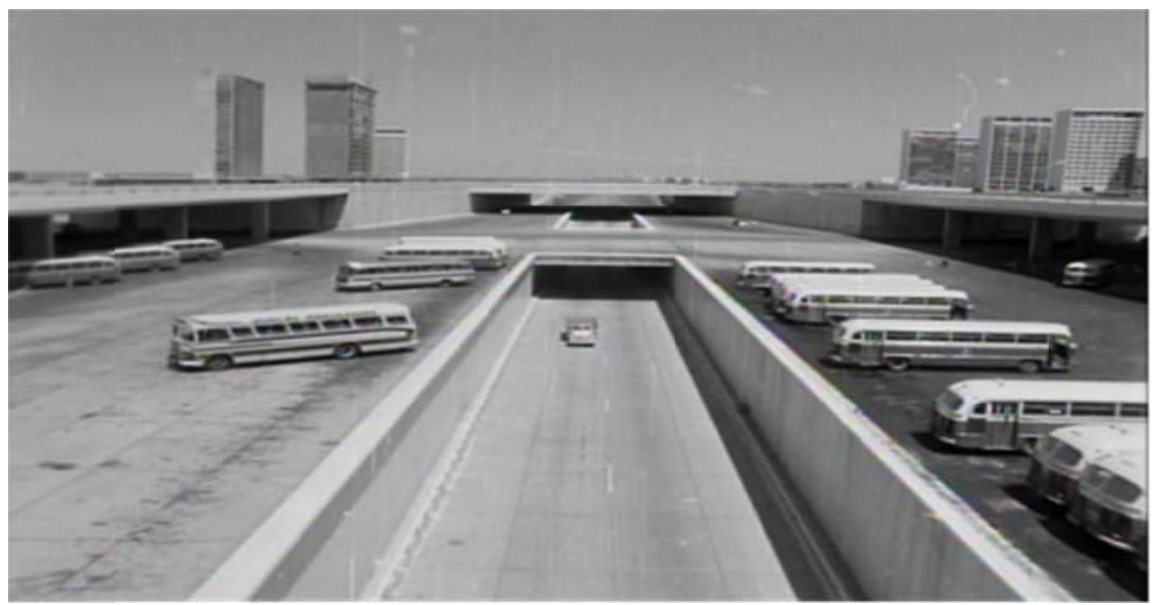

Figura 49: Rodoviária. Still de "Brasília: planejamento urbano", Fernando Cony Campos, 1964. Fonte: CTAv-MinC.

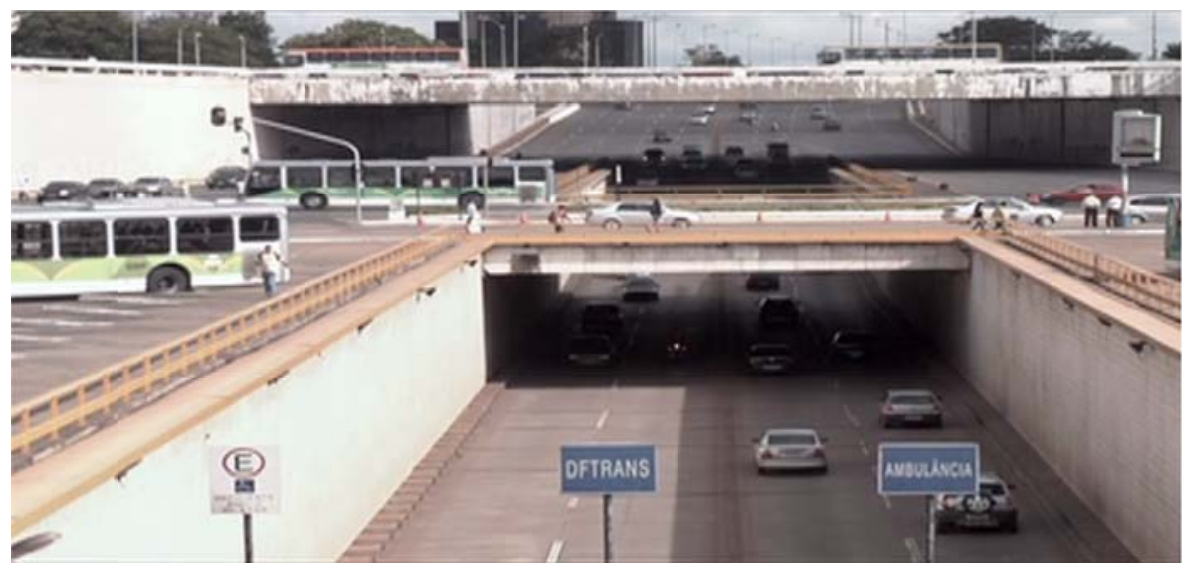

Figura 50: Rodoviária. Still do filme "Braxília", de Danyella Proenıça, 2010.

No entanto, as várias modificações que se aplicaram no centro da capital, alterando os fluxos e usos propostos, como os descritos por Lucio Costa na citação acima, resultam hoje num espaço sem integração mas que contrapõe a grandiosidade da estrutura de suas plataformas, vãos e edificações, com a ostensiva ocupação e apropriação desses espaços "vazios".

A plataforma é, na verdade, um imenso viaduto que abriga amplos espaços de fluxos, mas também se configura como um grande vazio moderno entre a área central sul e norte da cidade. A estação materializa de certa forma o espaço inabitado da modernidade marcado pela velocidade do intenso fluxo de veículos e a falta de integração da escala gregária de Brasília, e mesmo com o restante do Plano Piloto. (SABOIA, 2010).

Com relação às modificações que se impuseram durante a implantação do Plano, na qual a mais significativa e que acabou quase que por determinar grande parte das outras foi o deslocamento para leste de todo o conjunto urbano, esta alteração, que visava aproximar a cidade do lago, causou uma descontinuidade na área central no que diz respeito às cotas 
de nível, com consequências no acesso e fluxo de pedestres e veículos. Carpintero comenta que a partir dessas modificações:

O centro urbano de Brasília nunca se completou e, portanto, nunca teve condições de existir de modo cabal. As alterações sofridas, as áreas não ocupadas, os projetos mal elaborados, os usos inadequados e a privatização de espaços públicos tudo leva a um esfacelamento e a uma desintegração de suas partes. A demasiada setorização imposta pela NOVACAP, a ampliação excessiva de suas áreas, demonstrada pelas áreas vazias, leva muito mais ao afastamento que ao convívio e a concentração imaginados por Lucio Costa. (CARPINTERO, 1998, p. 217)

$\mathrm{Na}$ área central principalmente nos setores comerciais e hoteleiros observa-se uma descontinuidade tanto no fluxo de veículos quanto no de pedestres, salvo em alguns percursos no Setor Comercial Sul, onde galerias que atravessam os diversos blocos de edifícios oferecem um prosseguimento de fluxo. E a paisagem dessa área pode ser muitas vezes reconhecida como nas imagens baixo (Figura $5^{1}$ e Figura 512).
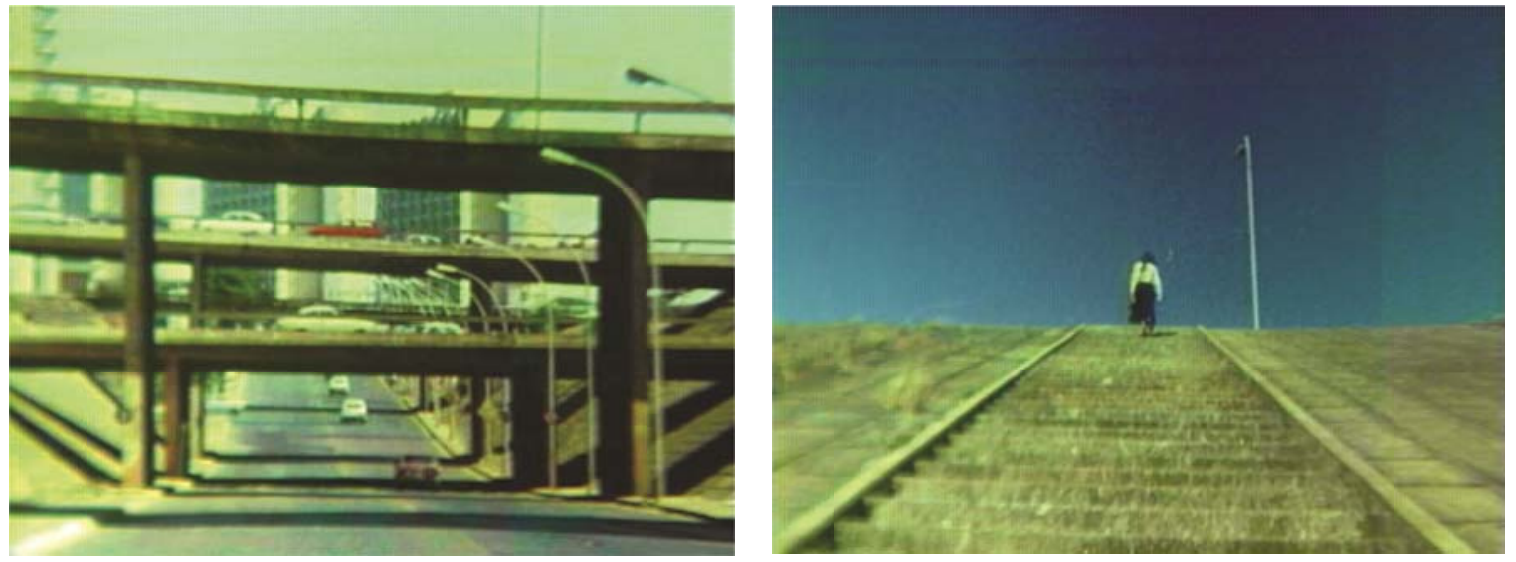

Figura 51 e Figura 52: via S2 e escadaria no Setor Comercial Sul. Stills do filme "Brasiliários", de Zuleica Porto e Sérgio Bazi, 1986.

Mas Carpintero refere-se principalmente a uma noção de centro urbano que não se aplica ao centro de Brasília, ou à sua escala gregária, nos dias atuais, Saboia (2010) esclarece que:

A reconfiguração sócio-espacial configura a última narrativa da consolidação da rodoviária como centralidade de Brasília. A consequência direta do impacto das cidades satélites no Plano Piloto foi o fato de que a rodoviária deixa de ser interestadual e passa a ser predominantemente a rodoviária local da cidade metropolitana. Na década de 1980 , o centro urbano começa a ser muito mais vivenciado pela população que trabalha no Plano Piloto e frequenta a rodoviária como parada obrigatória antes de chegar em casa. A população que mora fora do Plano Piloto faz da área central de Brasília a parada e momento para compras, serviços e lazer antes da volta para casa. Duas Brasílias entram em convergência: a Brasília construída e idealizada em 196o e as Brasílias periféricas em contínuo crescimento. 


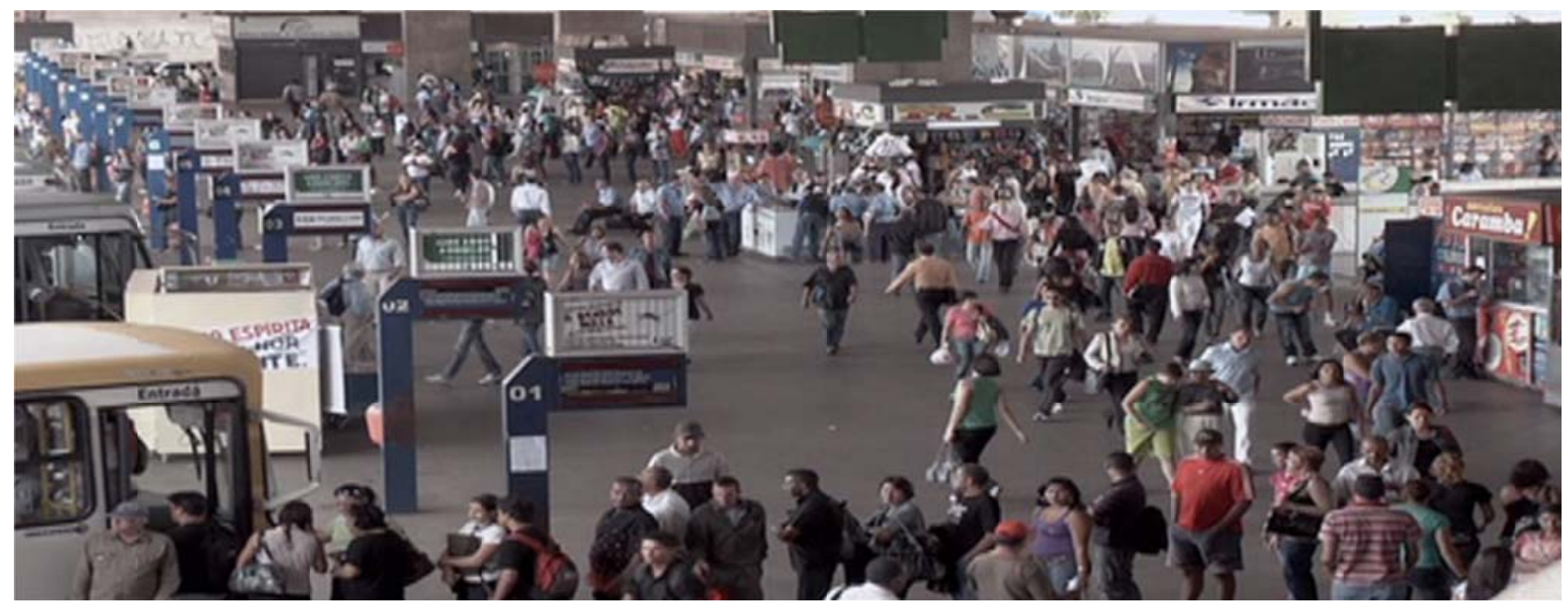

Figura 53: Rodoviária. Still do filme "Braxília", de Danyella Proença, 2010.

Outro percurso que se estabelece é pelas rodovias que fazem a ligação entre o Plano Piloto e as Cidades-Satélites, que desde o início da construção da capital iniciaram seu processo de consolidação. Distantes cerca de 30 quilômetros do Plano Piloto, para além do chamado "cinturão de preservação", que visava proteger as nascentes e rios que abastecem a região, esses núcleos urbanos são responsáveis por absorver grande parte da população que não pode se estabelecer no Plano Piloto. Trabalhadores e suas famílias realizam até hoje grandes percursos em direção às Satélites, utilizando automóvel ou transporte coletivo que parte da rodoviária, espaço que se tornou o ponto de contato entre o Plano e as Satélites.

A necessidade de explicar a "nova" lógica das concepções do Plano Piloto inspirou alguns filmes da primeira década que eram quase um "modo de usar" e esclarecer ao observador externo como era a vida na cidade planejada e ordenada de Brasília. Em "Brasília: Planejamento Urbano" (1964), o Relatório do Plano Piloto de Lucio Costa serviu de roteiro e narração do filme:

A cidade é formada por dois eixos: o monumental leste-oeste e o rodoviário norte-sul. Os dois eixos marcam os quadrantes da cidade, as faixas perpendiculares ao eixo monumental, tem a designação das centenas, as superiores ímpares e as inferiores pares. As faixas perpendiculares ao eixo rodoviário têm a designação das dezenas, com essas coordenadas localiza-se qualquer ponto em Brasília. O endereço em Brasília se reduz à seguinte expressão: SQS 304, B, 52. SQS é superquadra sul, 3040 número da quadra, $\mathrm{B}$ a designação do bloco de apartamentos, 52 o número do apartamento.

E em "Brasília, contradições de uma cidade nova" (1967), isso acontece na primeira parte do filme, mostrando o funcionamento da cidade com um deslocamento suave. O diretor Joaquim Pedro de Andrade descreve, através do narrador do filme e utilizando imagens de percursos de 
automóvel, as amenidades das quais usufruem os moradores do Plano Piloto. Mesmo já antecipando algumas críticas, contrasta-o na segunda parte com a cor da terra, a sujeira, a pobreza e a realidade brasileira que se faz presente em Brasília, mostrados através de percursos de ônibus pela recém-construída Cidade-Satélite.

Em diversos filmes, os percursos são utilizados para demonstrar a vivência em Brasília, a apropriação de seus espaços, ou as críticas a uma cidade que se mostra por vezes impessoal ou demasiadamente ampla e vazia. Os percursos descritos acima, que demonstram a relação de modernidade e velocidade no imaginário da cidade modernista, foram captados pelas lentes dos cinegrafistas desde as primeiras filmagens e até o presente momento fazem parte quase que inevitável nas suas representações.

\subsection{Análise dos filmes}

Brasília aglutinou diversas vertentes teóricas a respeito da organização da cidade moderna, desde a cidade industrial até as grandes rodovias das cidades americanas, buscando na valorização do veículo individual as prerrogativas para as definições de formas e fluxos na cidade. A velocidade e a máquina, amplamente aclamadas pelas vanguardas, representados na pintura, no cinema, na música e na literatura, fazem parte de uma imagem de modernidade. Ao representar este anseio, a construção de Brasília materializou no terreno, mas também no imaginário, esta estreita relação de modernidade e velocidade.

O cineasta Sergio Moriconi escreve em "Cinema: apontamentos para uma história" que é possível pensar numa "equivalência entre a invenção do cinema e a construção (ou invenção) de Brasília" (2012, p. 21), não somente pelo acontecimento inédito que ambos representam, mas pelo fato de um ter dado suporte e alimentado o imaginário do outro. Para o autor, o cinematógrafo possibilitou a captação de imagens em movimento e realizou um desejo alimentado há séculos.

A aventura da construção da capital e toda a sua carga simbólica foram documentadas pelas lentes do cinematógrafo criado por Lumière: "Nos planos cinematográfico e simbólico, a edificação de Brasília era - por assim dizer - a "Chegada do Trem na Estação de Ciotat", registro histórico dos irmãos Lumière e que marca a invenção do cinematógrafo". Moriconi coloca a questão: "Seria um exagero dizer que a difusão das primeiras imagens de Brasília teria produzido abalo semelhante no imaginário de pessoas do mundo inteiro?" (idem, p. 21).

A construção de Brasília forneceu imagens captadas e divulgadas das mais diversas maneiras: fotos, filmes, jornais e revistas. O artigo 19 da Lei 
$\mathrm{n}^{\circ}$ 2.874, de 1956, de criação da NOVACAP, determinou a obrigatoriedade de divulgação mensal de todos os atos da Diretoria, o que ocasionou, àquela época, o surgimento da "Revista Brasília". Segundo Cappello (2010), a publicação passou a ser editada, mensalmente, a partir de janeiro de 1957, e tinha como objetivo não apenas documentar, mas também defender a construção, a arquitetura e o urbanismo da nova Capital do Brasil.

A revista conta com depoimentos de Juscelino Kubitschek, Oscar Niemeyer, Lucio Costa, Israel Pinheiro entre outros importantes políticos, arquitetos, urbanistas e intelectuais do país. Os artigos, que defendem a ideia da mudança da capital, passam a relatar, com ampla cobertura fotográfica, inclusive com fotos aéreas, o cotidiano do canteiro de obras de Brasília, a história de sua construção, inauguração e consolidação, expondo os detalhes de sua arquitetura e urbanismo, acompanhando passo a passo o nascimento da cidade: a venda dos primeiros lotes, as primeiras construções, as primeiras casas populares, os primeiros blocos de apartamentos, as primeiras lojas, o estabelecimento das primeiras escolas e os primeiros eventos sociais. (CAPPELLO, 2010)
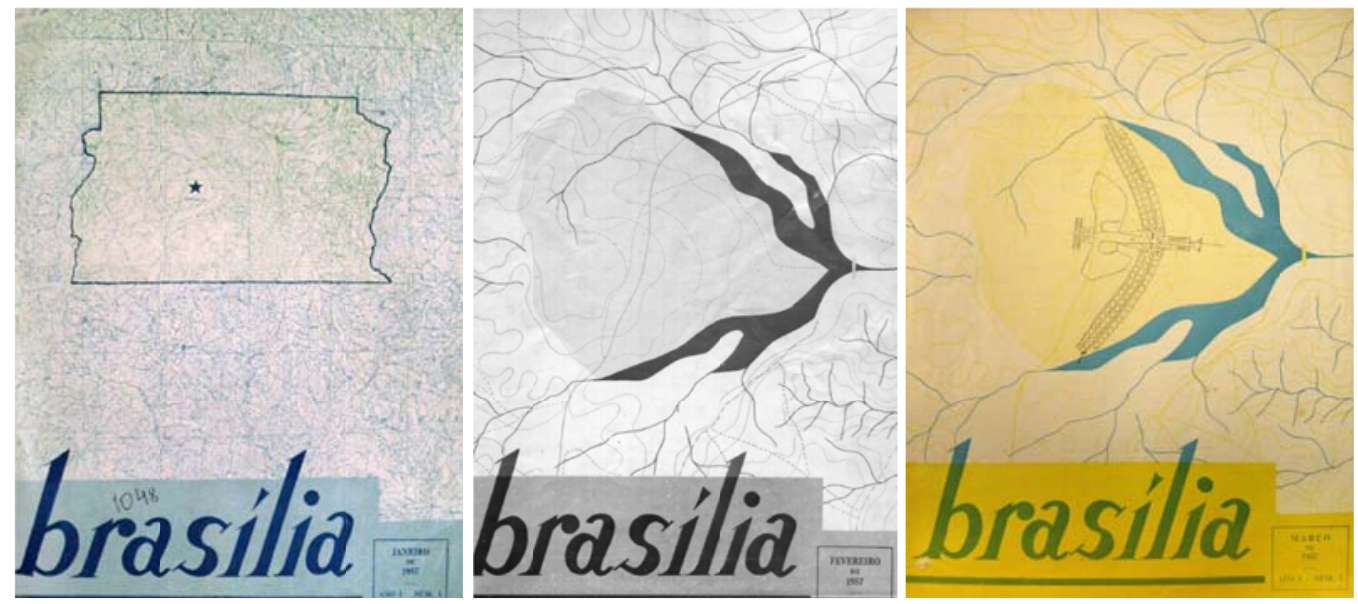

Figura 54: Capas dos números da Revista Brasília (1) janeiro 1957 „2) fevereiro 1957 e (3) março de 1957. Fonte: Arquivo Público do Distrito Federal - ArPDF.

Além da "Revista Brasília", que trazia os registros iniciais da construção, os registros audiovisuais da capital começaram com a "Companhia Urbanizadora da Nova Capital" do Brasil (NOVACAP), que possui acervo com mais de 60 filmes em preto-e-branco e em cores, de 16 e $35 \mathrm{~mm}$, que documentam desde a construção de Brasília, passando por momentos de solenidades de inauguração de prédios e monumentos da cidade, até os primeiros anos da capital. Este acervo foi cedido, mediante Decreto-Lei no 8.530 , do dia 14/03/1985, ao Arquivo Público do Distrito Federal ${ }^{37}$.

${ }^{37}$ Fonte: http://www.novacap.df.gov.br/sobre-a-novacap/acervo.html, acesso em $12 / 07 / 2013$. 
Os cinejornais eram também instrumentos de difusão de imagens da construção de Brasília, muitos deles produzidos por Jean Manzon, fotógrafo francês que veio para o Brasil após a Segunda Guerra Mundial e foi convidado pelo presidente Juscelino Kubitschek a fotografar Brasília e demais obras do governo. A parcialidade e o tom de "propaganda" dos documentários são resultado do trabalho de um fotógrafo contratado pelo governo: "As primeiras imagens de Brasília" ${ }^{>} 6$ (1957) se inicia com imagens do presidente a bordo de seu avião, pois "Brasília é a primeira metrópole a ser construída na idade da aviação" ${ }^{38}$, observando a cidade que ganha dimensões e incentiva a abertura de caminhos pelo interior do país.

Brasília atraiu migrantes de todas as regiões do país, o que foi considerado uma "aventura" especialmente nos primeiros anos de sua construção, que durou apenas três anos desde o concurso até sua inauguração. A mudança da capital do Rio de Janeiro para o Planalto Central envolveu-se de mitos, cujas raízes remontam às primeiras intenções de mudança da capital para o interior do país desde o século XVIII, o que desacreditava por muitos a viabilidade de constituir o governo federal distante dos tradicionais centros socioeconômicos do país. A oposição sofrida pelo governo de Juscelino Kubitschek contra a construção da capital no interior do país foi constante e acirrada durante a implantação e mesmo nos primeiros anos de consolidação da capital. Dessa forma, para o Estado era importante reforçar o sentido de progresso e modernidade, almejado por um país com graves diferenças sociais e que lutava contra o subdesenvolvimento.

Contudo, esses registros cinematográficos vão além das fontes oficiais do governo de Juscelino Kubitschek. Cineastas, principalmente os vinculados ao movimento do Cinema Novo, como Glauber Rocha, Nelson Pereira dos Santos e Cacá Diegues retrataram as mudanças que aconteciam no país como um todo. "Brasília, contradições de uma cidade nova" (Joaquim Pedro de Andrade, 1967) evidencia pela primeira vez essa dicotomia. Finaliza com a seguinte narração:

\begin{abstract}
Brasília foi a grande oportunidade que se abriu à arquitetura brasileira: uma cidade inteira a ser feita desde o começo, dentro de uma moderna técnica urbanística e com total liberdade imaginativa. Ao expelir de seu seio os homens humildes que a construíram e os que a ela ainda hoje acorrem, Brasília encarna o conflito básico da arte brasileira, fora do alcance da maioria do povo. O plano dos arquitetos propôs uma cidade justa, sem discriminações sociais. Mas, à medida que o plano se tornava realidade, os problemas cresciam para além das fronteiras urbanas em que se procurava contê-los. São problemas nacionais, de todas as cidades brasileiras, que
\end{abstract}

${ }^{38}$ Este trecho da narração do filme, no entanto, desconsidera a cidade de Goiânia, que, planejada para ser a capital do estado de Goiás, já considerava em seu plano urbanístico, projeto de Attilio Corrêa Lima, em 1933, a localização do aeroporto. 
nesta, generosamente concebida, se revelam com insuportável clareza. É preciso mudar essa realidade para que no rosto do povo se descubra quanto uma cidade pode ser bela ${ }^{39}$.

Brasília foi vítima de uma representação dicotômica e imprecisa que "não dá conta do seu futurismo: ou se contava a história oficial dos governantes pioneiros ou dos trabalhadores, candangos e migrantes que vieram construir esta cidade monumento" (MONTORO, 2012, p. 195). A nova capital causou impacto sobre alguns cineastas estrangeiros e brasileiros, que a retrataram muitas vezes num amargor "antimudancista", outras vezes como o símbolo de uma grande esperança.

Realizar a análise dos filmes produzidos em Brasília significa olhar a cidade enquanto imagem-movimento, olhar seus percursos enquanto duração e suas paisagens no decurso do fluxo cotidiano. Cada filme, separadamente, pode fornecer material para análise, porém uma amostragem maior, representativa de cada período pode levar a uma observação mais ampliada e contextualizada. Ambicionou-se abranger uma quantidade maior de filmes para que fosse possível realizar uma comparação entre temas e abordagens, evitando se comprometer com um ponto de vista específico de um ou outro diretor.

Os filmes foram divididos por períodos temáticos para facilitar a inserção de seu tema no contexto histórico, pois, mesmo buscando questões específicas, os filmes trazem muitas reflexões e informações históricas, sendo, portanto, um material muito rico para análises em outros campos. Marc Ferro (1975, p. 5), historiador francês, que pesquisa a relação cinema-história, diz que, seja fonte documental ou fictícia, a história de um filme já é história e é passível de análise das imagens dentro de uma contextualização política, econômica, cultural e social e preocupa-o a falta de interesse nesse tipo de documento no estudo da história. Em termos gerais, pode-se dizer que desde o surgimento do cinema com os irmãos Lumière, em 1895, há reflexos dessa relação entre o cinema e a história.

Resta estudar o filme, associá-lo ao mundo que o produz. A hipótese? Que o filme, imagem ou não da realidade, documento ou ficção, intriga autêntica ou pura invenção, é História; o postulado? Que aquilo que não se realizou, as crenças, as intenções, o imaginário do homem, é tanto a História quanto a História. (FERRO, 1975, p. 5)

Esta pesquisa inclui desde "As primeiras imagens de Brasília", de Jean Manzon, de 1957, até as produções mais recentes, reunindo material representativo da produção brasiliense de cinema, de 1960 até 2012, e busca extrair informações com o intuito de analisar o cinema produzido

${ }^{39}$ Trecho de narração em "Brasília, contradições de uma cidade nova”, 1967. 
na cidade e sobre ela. Para se ter uma ideia da quantidade de filmes realizados em Brasília, foi mapeada uma produção de mais de 500 filmes, que participaram do Festival de Brasília do Cinema Brasileiro desde 1965 . A pesquisa realizada por Berê Bahia mapeou o que ela chamou de Brasiliários:

Brasiliários (neologismo criado por Clarice Lispector) são todos os diretores brasilienses e brasileiros que tentaram e conseguiram (ou não), desvendar a esfinge "Brasília" no seu contexto físico espacial, histórico, filosófico, político, social, cultural e acima de tudo o lado humano em suas interfaces, através dos filmes: documentários, ficções e animações. (BAHIA, 2012, p. 29)

Ressalta-se que nesse número não estão somados muitos dos filmes realizados pelos cursos de cinema, filmes educativos, documentários e reportagens para televisão ou filmes cujos diretores e produtores não inscreveram para o Festival.

Para ter acesso ao material buscou-se uma lista de instituições de acervos, realizadores e produtores. Para chegar a esse cadastro foram utilizadas fontes como:

- lista de entidades de acervo de filmes tais como: cinemateca do Museu de Arte Moderna, MAM-RJ, Cinemateca Brasileira em São Paulo, Fundação Cinememória e acervo do Centro de Produção Cultural e Educativa, CPCE-UnB, em Brasília etc.;

- bancos de conteúdos culturais (bcc.org.br) e difusores, como a Programadora Brasil (programadorabrasil.org.br);

- Faculdade de Comunicação da Universidade de Brasília;

- Secretaria de Cultura do Governo do Distrito Federal, responsável pela realização do Festival de Brasília do Cinema Brasileiro;

- contato direto com pesquisadores, realizadores, produtores e diretores.

A realização de duas mostras de filmes apoiadas pela Universidade de Brasília através da Chamada Pública de Propostas "UnB 50 anos", número 01/2012, relativa a iniciativas relacionadas à comemoração do cinquentenário da Universidade de Brasília, permitiu expandir o acesso ao material para pesquisa (filmes, entrevistas, livros), com os contatos realizados anterior e posteriormente às mostras.

Após um primeiro levantamento seguiu-se o mapeamento de cada filme de acordo com o tema, ano de execução, diretor e equipe, duração, gênero. As informações sobre os diretores que atuam na cidade ou têm uma linha de trabalho já conhecida também se mostraram fundamentais. A proposta da pesquisa previu o visionamento de todos os filmes selecionados e inclui um mapeamento de trechos importantes, muitas vezes demandando a extração de excertos de frames ou trechos e sua transcrição para posterior análise. A investigação e a indexação das informações foram realizadas de maneira a facilitar a consulta à pesquisa 
e ao conjunto de dados sobre cada obra, constituído o corpo substantivo da filmografia de Brasília.

As fichas catalográficas para organização do material da pesquisa tiveram como base e referência a publicação da pesquisa "Filmografia do Hábitat", coordenada pelo arquiteto e urbanista Carlos Nelson Ferreira dos Santos, em 1982. Essa pesquisa agrupou em catálogo o material audiovisual disponível no país nas áreas de desenvolvimento urbano, do saneamento básico e da habitação e tinha como objetivo mostrar um caminho, indicar mais um instrumento para os que atuam sobre os meios urbanos. Fez mais do que isso ao indicar a importância da utilização da ferramenta audiovisual como instrumento de abordagem das cidades e da vida urbana. Como o próprio autor relata, pesquisas como essas podem se mostrar demasiado vastas e sempre incompletas à medida que nelas se avança, mas valem o esforço de rastreamento e homogeneização das informações.

O livro "Cinema: apontamentos para uma história", do jornalista e cineasta brasiliense Sérgio Moriconi, lançado em 2012, serviu de referência histórica para as análises da cinematografia brasiliense, amparado pelas entrevistas realizadas e transcritas em "Cineastas de Brasília", de Raquel Maranhão Sá, de 2003. O livro "A evolução do cinema brasileiro no século XX", de Ricardo Wahrendorf e Tania Montoro, trouxe o contexto brasileiro, como ferramenta para se entender o que se passava na capital do país.

Dessa maneira, os subcapítulos que se seguem resultam da análise da filmografia de Brasília, percorrendo uma linha histórica, marcada pelos períodos importantes para a capital: a sua construção, tratada na fase nomeada "do mito à realidade" quando ocorre de fato a consolidação da capital, os percursos visíveis nos filmes mostram a narrativa da cidade total, os personagens são divididos em grupos (operários x funcionários públicos, cidade branca x cidade cor de terra); "censura e metáfora" marca a fase em que a questão política durante o regime militar vai alterar radicalmente o discurso e a linguagem cinematográfica ao tratar das questões sociais que envolvem a cidade, seus percursos mostram uma fase onde a fabulação aparece como necessidade de expressão; em "a cidade se descobre" narra-se o momento em que os brasilienses percebem a cidade e a identificam, já nos ares da redemocratização política, mostra a busca da identidade, o percurso se faz pela cidade não-oficial, para em seguida, a partir de uma postura crítica, reivindicar os lugares na fase chamada de "crise de identidade"; o "vazio" moderno começa a ser ocupado, é o espaço expectante, da deambulação criativa e crítica. Por fim, "da periferia ao centro" trata da apropriação e apreensão de uma cidade que se descobre metrópole, mas que também se descobre humana, os espaços compartilhados, as estórias misturadas acontecem durante $\mathrm{o}$ percurso. 


\subsubsection{Do mito à realidade: "Contradições de uma cidade nova"}

O plano dos arquitetos propôs uma cidade justa, sem discriminações sociais. Mas à medida que o plano se tornava realidade, os problemas cresciam para além das fronteiras urbanas em que se procurava conter. Na verdade são problemas nacionais. E de todas as cidades brasileiras, que nesta generosamente concebida, se revelam com insuportável clareza.

É preciso mudar essa realidade para que no rosto do povo se descubra quanto uma cidade pode ser bela. "Brasília: contradições de uma cidade nova", Joaquim Pedro de Andrade, 1967.

Os primeiros cinegrafistas que chegaram a Brasília se depararam com a certeza de estarem vivenciando um momento como poucos, afinal, uma cidade toda se construindo em passos acelerados, o imenso canteiro de obras e a quantidade de pessoas envolvidas na sua realização é um fato que, aos olhos de repórteres, fotógrafos e cinegrafistas deve ter causado extremo impacto e deslumbramento. Entre eles, destacam-se, Herbert Richers (1923-2009), Isaac Rozemberg, Jean Manzon (1915-1990) e José e Sávio Silva, levados a Brasília pelo próprio Juscelino Kubitschek.

Desses primeiros anos, muito material foi perdido. Alguns são praticamente impossíveis de encontrar, como é o caso de "Les pionniers" (Os bandeirantes), filme de Marcel Camus, rodado em 1959, cujo negativo encontra-se na França. Esse filme, representante do olhar estrangeiro e de "um imaginário mitológico diante do encanto e curiosidade que permaneceriam vivos por muitos anos entre documentaristas e ficcionistas estrangeiros" (MORICONI, 2012, p. 33), que, assim como em "O homem do Rio" (Philippe De Broca, 1963), reatualiza o mito do paraíso a ser colonizado. Ao mostrar o sertanejo simples e receptivo em contato com a aventura da construção de uma cidade que representaria a civilização, o futuro, onde tudo é possível, mostrava a colonização do interior do país pelos próprios brasileiros.

interior do país pelos próprios brasileiros. 
O sertão brasileiro, antes considerado um espaço bruto e vazio, lugar de atraso, da pobreza, de uma não civilização, passa a ser, com a construção die Brasília, o centro irradiador de uma nova civilização. Uma nova civilização erguida e habitada por um paradoxal "bom selvagem civilizado". (MORICONI, 2012, p. 45)

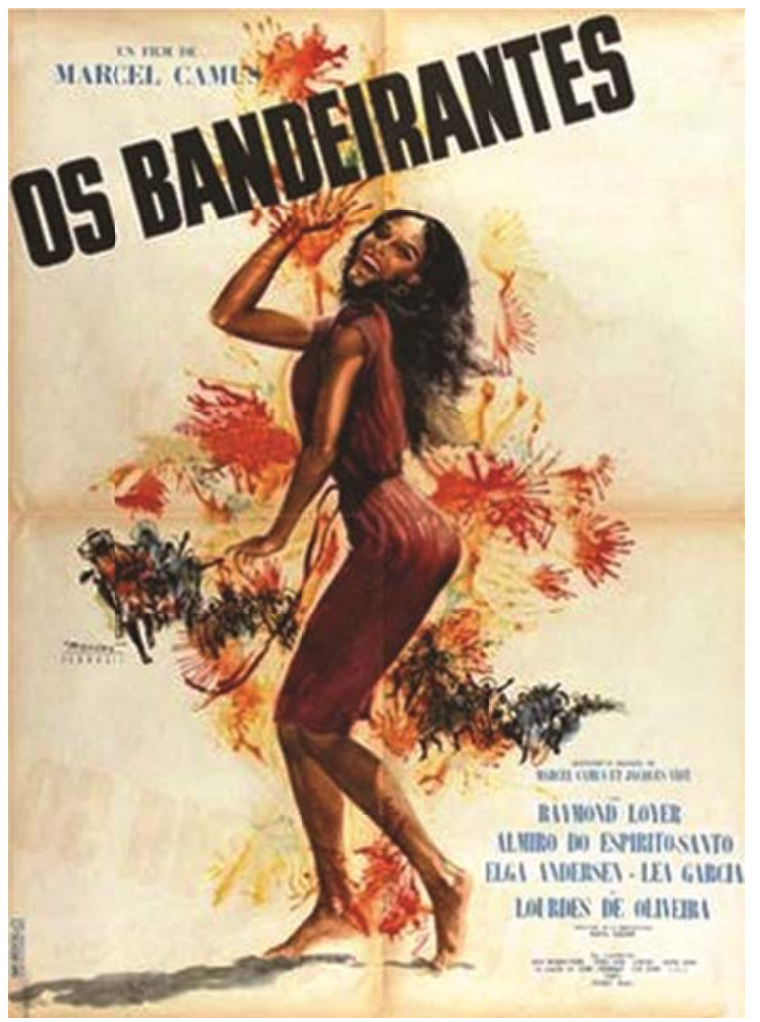

Figura 55: Cartaz do filme "Os Bandeirantes".

Fonte: encyclocine.com, acesso em 10.06.2013.

No discurso oficial, visto nos cinejornais, como "As primeiras imagens de Brasília" (Jean Manzon, 1957), o Nordeste e outras regiões do Brasil profundo vão merecer do governo, dos intelectuais e artistas uma atenção toda especial. Essas regiões e os indivíduos que nelas habitam estariam no centro da busca de uma autêntica identidade brasileira que Georgete Rodrigues, em sua tese "Ideologia, propaganda e imaginário social na construção de Brasília", aponta:

Tinha-se que despertar e nutrir o imaginário da população para que ela se mobilizasse a favor dessa empresa. Era preciso inventar uma memória, sacralizá-la e fazer da cidade a síntese e a representação do contexto de modernização que o governo almejava para o país. (1990 apud MORICONI, 2012, p. 45)).

No curta-metragem "As primeiras imagens de Brasília”, os primeiros passos da construção da capital federal são apresentados pelo então presidente JK, com discurso de desenvolvimento, progresso e integração nacional. Num tom de grandiosidade narrado por Luiz Jatobá ou pelo próprio presidente, mostram, em imagens aéreas, o gigantesco canteiro de 
obras e infraestrutura, movido por força humana em fileiras munidas de pás e enxadas. (...) "traçados os planos de vida ou de morte, pelos capitães da pacífica, mas dura batalha brasileira, os pesados engenhos dessa guerra redentora, abrem, conquistam, subjugam o espaço. A cidade nova estende seus braços às irmãs mais velhas". ${ }^{40}$

Ao mostrar as maquetes e obras nos edifícios principais, o discurso é de uma solução de grande harmonia e técnica, mas que remete a um passado clássico, como na frase narrada: "Cidade do futuro, terá como certas cidades clássicas da antiguidade, uma medida de graça arquitetônica. Nela, a idade da técnica reencontra a idade da harmonia. Virtudes que andam separadas nesses tempos de eclosão industrial" ${ }^{41}$.

Faz crer que a modernidade ainda não era totalmente digerível, pois ainda não era fato. No Brasil, os traços modernistas da arquitetura chegaram antes. A técnica era puramente manual e a indústria ainda era rudimentar e incipiente. A cidade, assim como as principais estradas de ligação (como a Rodovia Belém - Brasília), foram construídas quase artesanalmente.
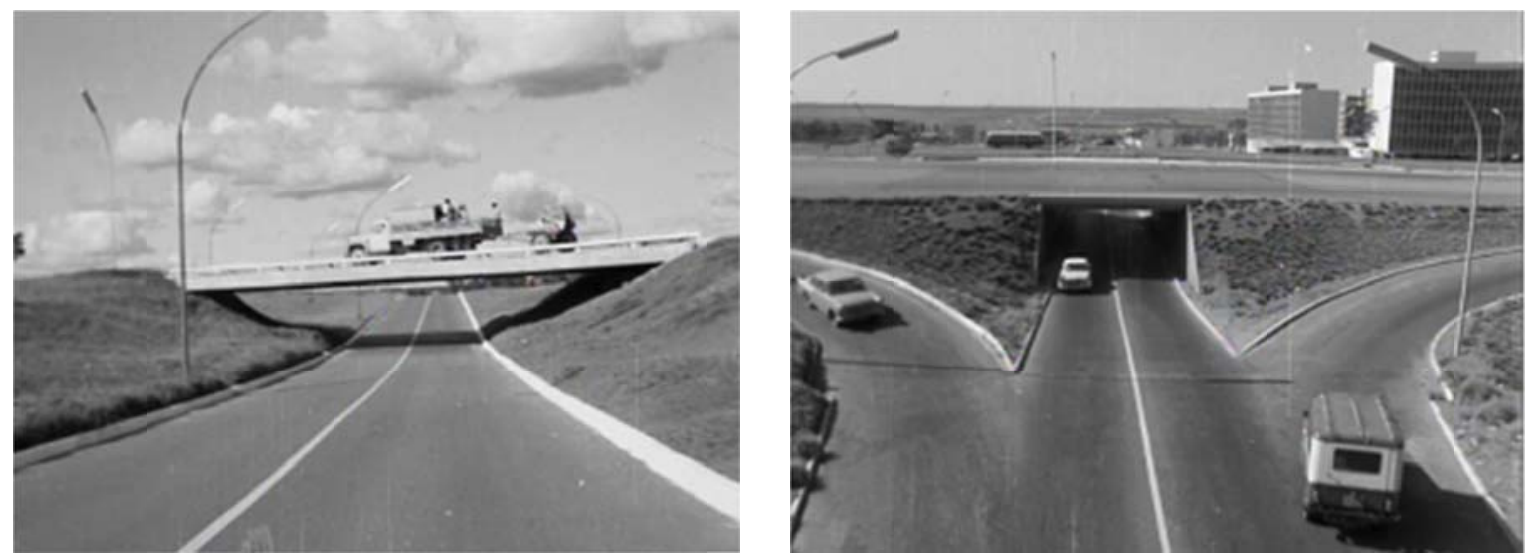

Figura 56: Stills do filme "Brasília, planejamento urbano", Fernando Cony Campos, 1964. Fonte: CTAv-MinC.

Nas cenas de filmes como "Brasília, planejamento urbano" (Fernando Cony, 1964) e "Brasília: contradições de uma cidade nova" (Joaquim Pedro de Andrade, 1967), realizados na primeira década da inauguração da capital, percebe-se a preocupação em mostrar o funcionamento do tráfego dos veículos, a organização e setorização da cidade, mostrando-a como um organismo resultante de um planejamento minucioso. São também mostrados, com orgulho, os edifícios símbolo da capital, como: a catedral, os palácios e as torres do Congresso. Os percursos pela cidade são narrados de maneira a apresentar a cidade ao espectador

\footnotetext{
${ }^{40}$ Trecho da narração de “As Primeiras Imagens de Brasília”, Jean Manzon, 1957.

${ }^{41}$ Idem.
} 
(provavelmente um espectador não habitante), enquanto a cidade é percorrida, de carro ou avião, em "Brasília: planejamento urbano", as principais “inovações” do Plano de Lucio Costa são apresentadas:

Assim, foi dado ao motorista da cidade todas as vantagens do motorista de estrada: tráfego desimpedido e contínuo. Deste modo, e com a introdução de trevos completos e passagens de níveis, o tráfego de automóveis e de ônibus se processa tanto na parte central como nos setores residenciais sem qualquer cruzamento. Fixada a rede geral do tráfego, estabeleceu-se tramas autônomas para o trânsito local dos pedestres garantindo-lhes o uso livre do chão.
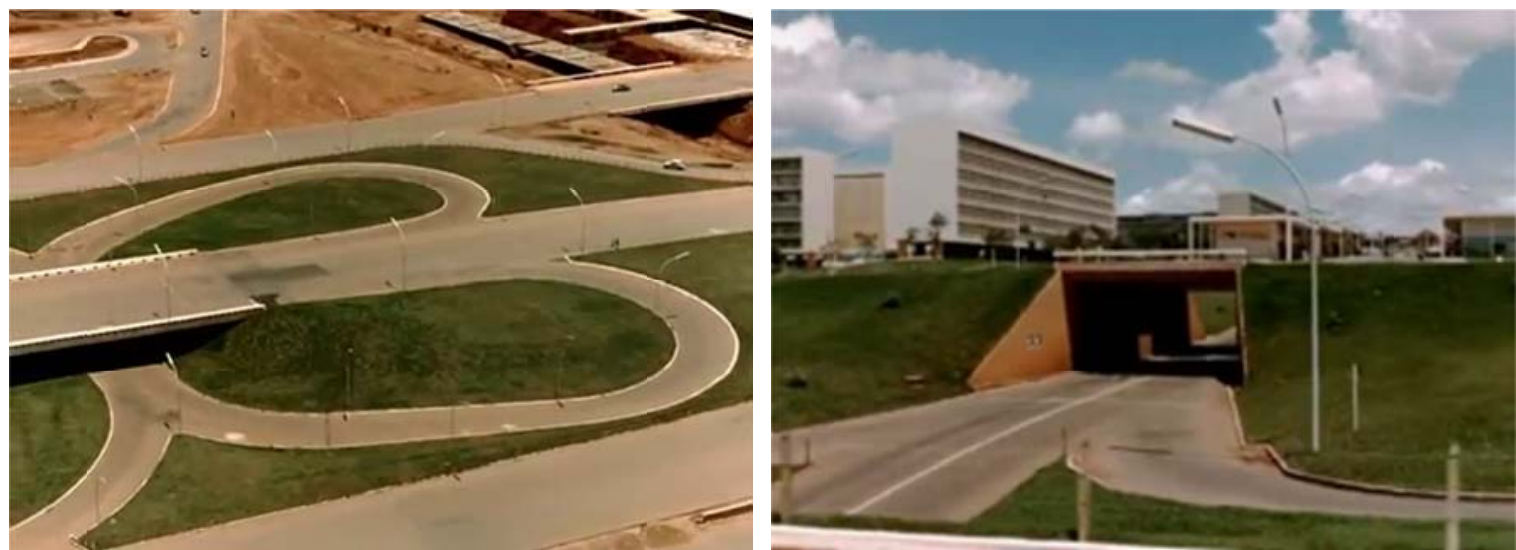

Figura 57: Stills do filme "Brasília, contradições de uma cidade nova", de Joaquim Pedro de Andrade, 1967. Fonte: Filmes do Serro.

Característica bastante marcante nas décadas de 1960 e 1970, pela influência do Cinema Novo, é a preocupação em mostrar a realidade dos trabalhadores na construção e o espaço segregado que foi se estabelecendo desde o início da ocupação do território. Os operários, que percorriam cerca de três horas, como narrado no filme, até a cidadesatélite, a cidade-dormitório, foram retratados em cenas filmadas dentro dos ônibus e na rodoviária do Plano Piloto, em "Brasília: contradições de uma cidade nova", e apresentam o "imaginário fundante da nova capital dos brasileiros que se alimenta das contradições do próprio país", como destaca Tania Montoro (2012, p. 200).

Os apartamentos de Brasília deveriam obedecer a três padrões econômicos distintos. Conforme o Plano, a cidade não seria dividida em bairros ricos e bairros pobres. Haveria integração em vez de discriminação. O que não houve. ${ }^{4 \mathbb{2}}$

${ }^{42}$ Trecho da narração de "Brasília, contradições de uma cidade nova”, 1967. 

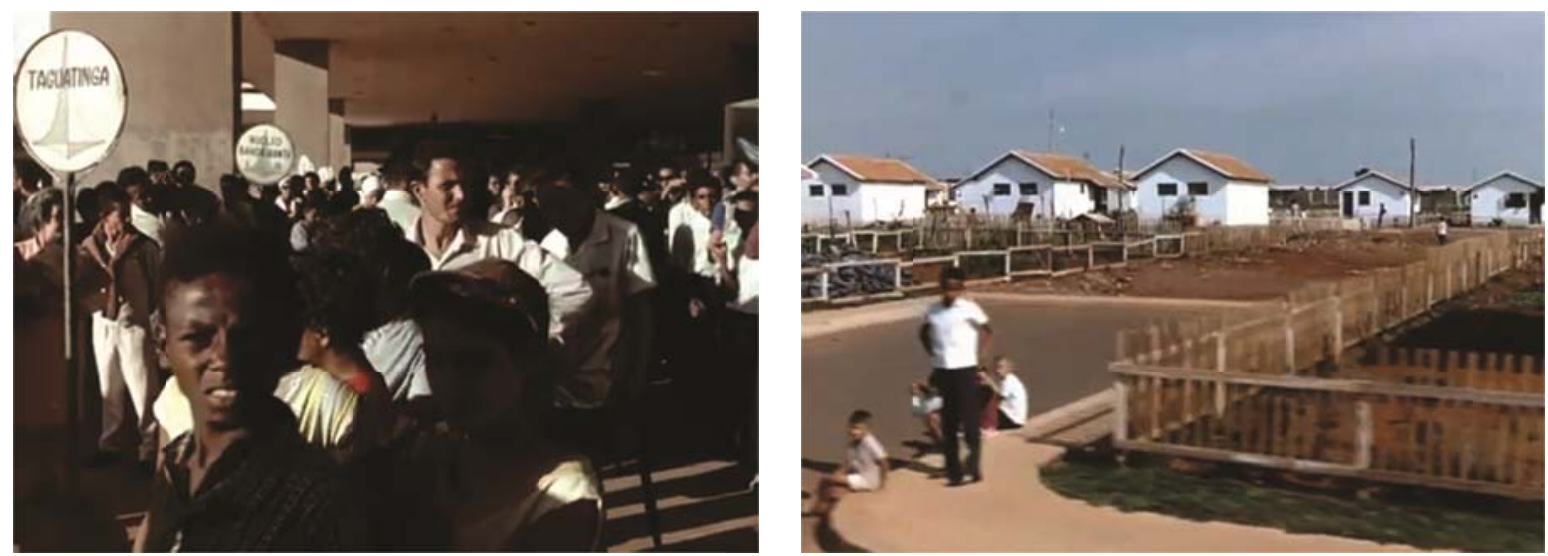

Figura 58: Stills do filme "Brasília, contradições de uma cidade nova", de Joaquim Pedro de Andrade, 1967. Fonte: Filmes do Serro.

Outro percurso começa a ser apresentado além das asas e eixos do Plano Piloto: o percurso do trabalhador que sai da rodoviária diariamente e vai até alguma cidade-satélite, que ainda é genérica e impessoal, e só se sabe seu nome pelas placas dos embarques na rodoviária.

Ao fim de uma viagem, que dura em média três horas, os operários chegam ao lugar onde residem: as chamadas cidades-satélites, ou cidades-dormitório. Nascidas espontaneamente, ou traçadas pelos tratores nas amplas áreas desertas em torno da capital, essas cidades se desenvolvem horizontalmente segundo um esquema urbanístico ultrapassado, em tudo oposto ao Plano de Brasília. ${ }^{43}$

Os filmes do início da década de 1960, de maneira geral, tendem a lidar com os contrastes sociais e contradições de classe, mas detecta-se otimismo em relação à possibilidade de transformação social a partir da conscientização do povo brasileiro que, acreditava-se, não tinha conhecimento da própria realidade. No entanto, em 1964, o golpe militar instaura pouco a pouco a censura e alguns assuntos saem de cena. Nos filmes pós-1964, o foco transporta-se para as classes médias urbanas, mais especificamente à situação dos intelectuais e artistas: é exemplo desse período "Terra em transe" (Glauber Rocha, 1967). Já os filmes feitos logo após o golpe, como "O leão das sete cabeças" (Glauber Rocha, 1970) e "Os herdeiros” (Cacá Diegues, 1969), tendem a ser extremamente pessimistas em suas reflexões sobre o fracasso do movimento progressista, a impotência dos intelectuais e o futuro ameaçador da política brasileira.

Em 1965, Pompeu de Souza, diretor e fundador da Faculdade de Comunicação da Universidade de Brasília, traz para a capital brasileira Paulo Emílio Salles Gomes, Jean Claude Bernardet e Nelson Pereira dos Santos. O objetivo era criar o Curso de Cinema da Universidade de

${ }^{43}$ Idem 
Brasília, o primeiro de nível superior no Brasil ${ }^{44}$, o que vinha ao encontro do sonho de Darcy Ribeiro para a UnB: "Uma Universidade tão inovadora no plano cultural, quanto o era a própria Brasília no plano urbanístico e arquitetural". (1978 apud MORICONI, 2012, p. 81) ${ }^{45}$.

Segundo Moriconi, o Curso de Cinema teve que percorrer uma "saga cinematográfica" (2012, p. 115), com períodos de intermitência: sendo o primeiro de março a outubro de 1965, quando então foi extinto pelo episódio da demissão coletiva dos professores. De 1965 até 1970 ficou limitado a algumas disciplinas do Instituto Central de Artes - Faculdade de Arquitetura e Urbanismo (ICA-FAU), até renascer por mais dois anos (de 1970 a 1972), quando foi definitivamente extinto e tornou-se parte do currículo do Departamento de Comunicação.

O filme de Nelson Pereira dos Santos "Fala Brasília" ${ }^{>7}$ (1966) foi o primeiro realizado dentro do Curso de Cinema e é quase um "Manifesto da Cultura Candanga" ${ }^{46}$, por realizar um resumo dos diversos sotaques vindos dos diferentes estados da federação, no recente fluxo de migração.

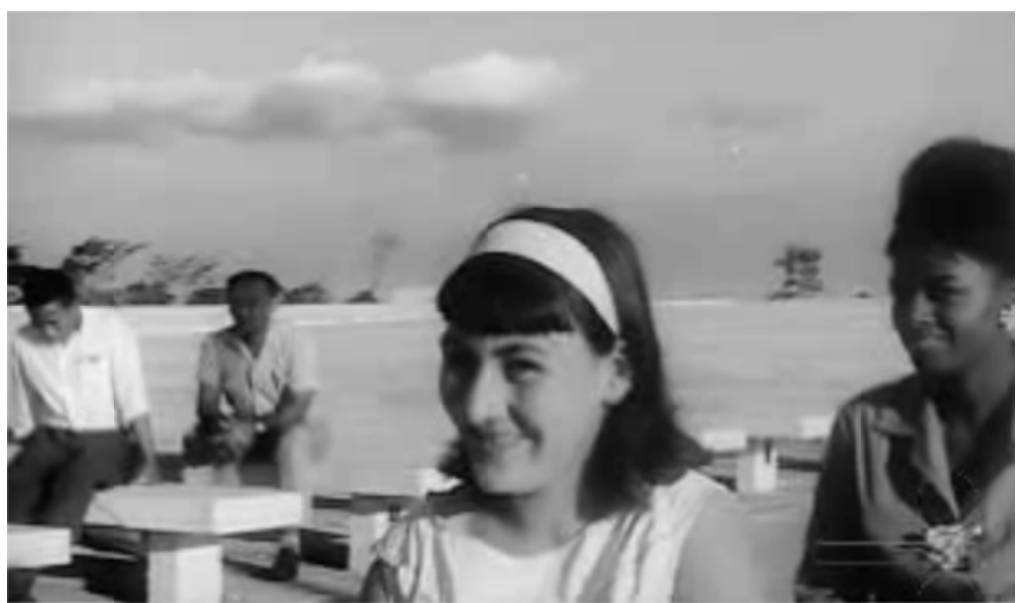

Figura 59: Still do filme "Fala Brasília", de Nelson Pereira dos Santos, 1966. Fonte: CPCE-UnB.

A década de 1960 refletiu no cinema o caldeirão de várias influências, discursos e resistências que a cidade vivenciava. Foi, ao mesmo tempo, o discurso político dos cinejornais, a efervescência intelectual e quase utópica da criação do Curso de Cinema na Universidade de Brasília e a influência estética e pesquisa sociológica que envolvia o movimento do Cinema Novo, no qual Brasília teve destacada participação. Brasília havia se tornado realidade.

${ }^{44}$ Moriconi lembra que "o libertário e revolucionário Curso de Cinema da Universidade de Brasília foi implantado um ano depois de instaurado o Golpe Militar de 1964". (MORICONI, 2012, p. 83)

${ }^{45}$ RIBEIRO, Darcy. “UnB: invenção e descaminho”. Avenir Editora, 1978.

${ }^{46}$ Vladimir Carvalho em "Cinema candango: matéria de jornal”, p.19. 


\subsubsection{Censura e metáfora: "Bravos guerreiros"}

Mas a linguagem dos poderosos não é a dos olhares ou dos gemidos é uma língua que eles só ensinam a quem estiver ao lado deles (...) Pra que dizer-lhes que o mundo é maior do que me deixaram ver.

Para que dizer-lhes que eu não era uma ilha. Mas o silêncio pesava dentro de mim, o silêncio crescia dentro de mim. $O$ silêncio se juntava a outros silêncios e me afogava. Foi então que meu silêncio virou grito e eu cuspi na cara do mundo. Proclamei minha traição, berrei no ouvido dos poderosos que eu não era um deles, que a minha traição era uma traição da traição maior. Da única traição que é a traição do homem pelo homem para servir só a si mesmo. Disse do nojo, disse da impostura desse mundo em que só é dado a quemjá tem. "O bravo guerreiro", Gustavo Dahl, 1969

Os anos 1970 foram de medo e silêncio, pela carga do momento de censura e violência imposto pelo governo militar. A linguagem da metáfora recoloca o cinema da urgência. Cacá Diegues, em "Os herdeiros" (1969), que faz parte da mesma safra de "Terra em transe" (Glauber Rocha, 1967) e "O bravo guerreiro" (Gustavo Dahl, 1968), fazem uma reflexão sobre a situação do país, de perplexidade após o agravamento da ditadura militar, em 1968, e do rumo que o Brasil havia tomado. Em filmes pessimistas, os cineastas falam da impotência e da sujeição progressiva do país ao novo regime. Mas, em Brasília, apenas uma década após sua inauguração, percebe-se a busca por afirmação da cultura da cidade, com filmes que buscam histórias de pessoas que tiveram suas vidas misturadas à da cidade ao mostrá-la como "confluência e síntese da história e da cultura brasileiras". (CARVALHO, 2002, p. 73) 

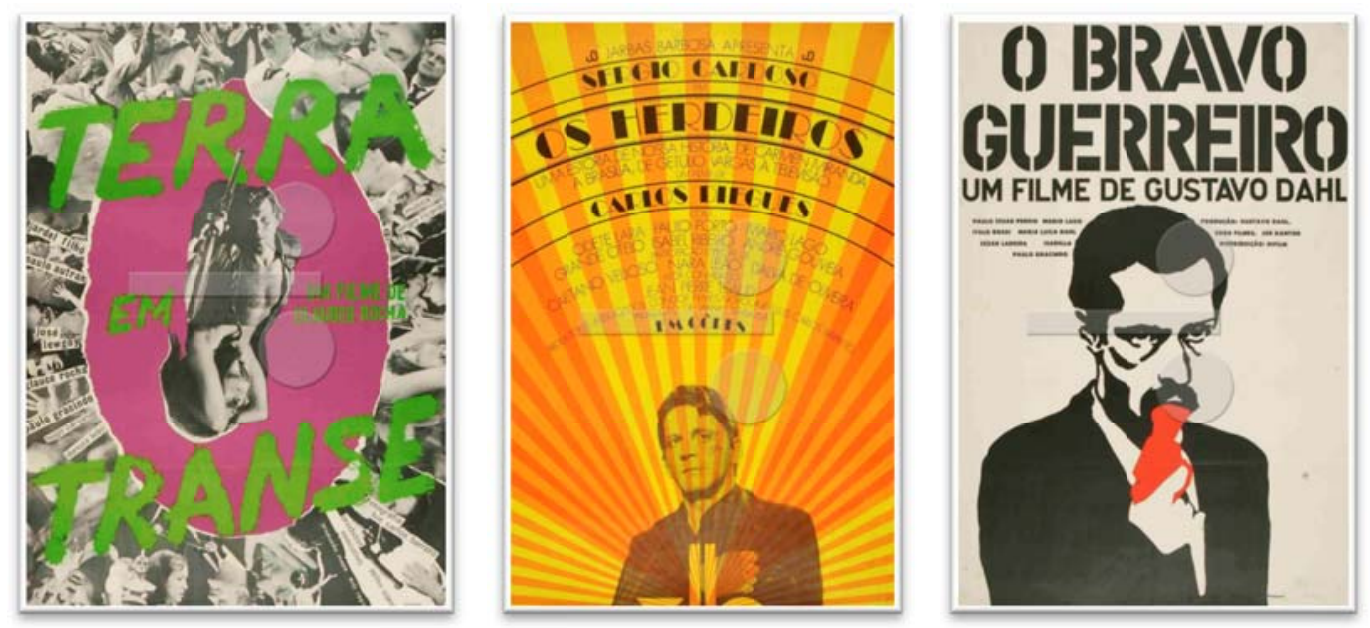

Figura 6o: Cartazes dos filmes "Terra em transe", "Os herdeiros", e "O bravo guerreiro". Fonte: Cinemateca de São Paulo.

Em 1977, Vladimir Carvalho escreve no jornal "Correio Braziliense" um artigo chamado "Brasília, um portal cinematográfico, entre o urbano e o arcaico" (2002, p. 81), título que carregava toda a carga simbólica da capital naquele período. Após a inauguração oficial de Brasília, vários edifícios ainda continuavam inacabados e a vida na cidade ainda se parecia muito com uma vida rural, em parte pela população que, em sua maioria, migrou de áreas rurais e trazia consigo essa cultura, mas, principalmente, por causa da falta de infraestrutura e porque a cidade ainda estava sendo construída em meio ao cerrado. No fillme "Vestibular $70^{\prime \prime 8}$ (Vladimir Carvalho, 1970), a Universidade de Brasília, que promove o exame para cerca de seis mil candidatos, ainda é um esqueleto de edifício pré-fabricado em concreto, acessível por caminhıs de tábuas, pinguelas sobre o chão de lama e contrapiso inacabado. Em "UnB: primeira experiência em pré-moldado" ${ }^{>9}$ (Heinz Forthman, 1970), usaram-se imagens que Forthmann havia feito durante a construção dos blocos de serviços gerais em 1962 para criar um vídeo quase didático sobre a técnica utilizada pela primeira vez no Brasil. As imagenıs não deixam dúvida desta relação entre o moderno e o arcaico, ao mostrarem a maneira manual como essas estruturas eram produzidas e montadas.

É um percurso por Brasília que se consolida como cidade, uma ponte entre o arcaico (que ainda é) e o moderno que se propôs a ser. Os caminhos são de pó ou lama, as construções ainda estão sem acabamento e utilizam-se técnicas inovadoras de concreto armado, porém, manualmente fabricadas. 

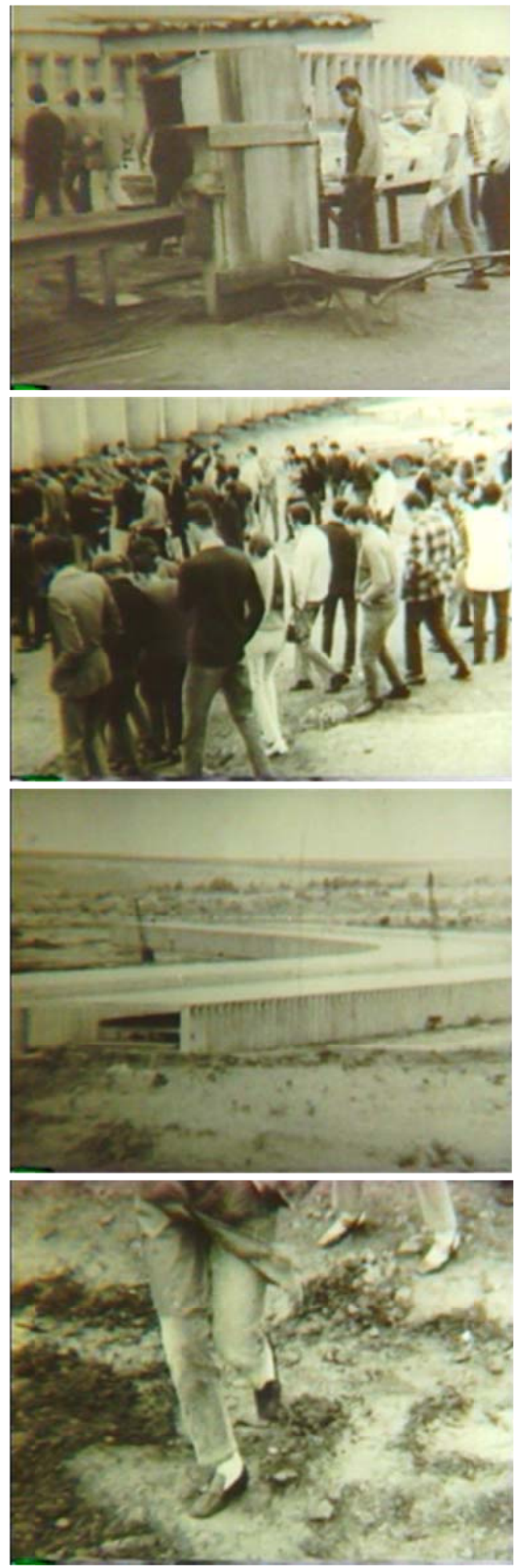

Figura 61: Stills do filme "Vestibular 70", Vladimir Carvalho, 1970. Fonte: CPCE-UnB. 
Brasília tem, em 1970, grandes nomes do cinema formando a "grande escola do documentário brasileiro" (CARVALHO, 2002), como denominava o cineasta e professor Fernando Duarte (1937), no Curso de Cinema da Universidade de Brasília. Essa escola do documentário filmou durante sete anos, enfrentando todo tipo de precariedade sob o amparo da instituição. Nesse período, investindo nas pesquisas no campo do documentário, buscava-se filmar e difundir qualquer tipo de fenômeno que fosse objeto de estudo dos diversos institutos e centros de pesquisa da universidade. A linguagem deveria se empenhar numa descoberta por meios, uma forma nova de ver os fenômenos, uma busca do moment revelateur ${ }^{47}$.

O cinema seria testemunha e intérprete da cidade-monumento em que Brasília vinha se transformando. Segundo Carvalho (2002), a universidade, com seu sentido de escola de formação e diversificação de mão de obra capaz de intervir criticamente na realidade social, política e econômica, utilizando o documentário como método de ensino e trabalho, capturou e fixou costumes e rituais indígenas no Xingu; manifestações de características medievais nas velhas cidades de Goiás; as consequências sociais e humanas da implantação de Brasília na região; a vida e as possíveis transformações da grande metrópole brasiliense; e os problemas de moradia, abastecimento, do trânsito ou do lar. O autor explica que é como se a câmera estivesse ligada a um microscópio, "flagrando as recônditas substâncias de seres nas experiências de laboratórios" (2002, p. 85 ). Foram filmados, num período de cinco anos, citando os mais importantes: "Brasília, ano 10" (Geraldo Sobral Rocha, 1970), "Itinerário de Niemeyer" (Vladimir Carvalho, 1974), e "Vila Boa de Goyaz" (Vladimir Carvalho, 1974). Como resultado do trabalho dos alunos, e com produção do departamento de Arquitetura e Urbanismo e apoio do professor Paulo Bicca, foi realizado "Ceilândia 76 ", com direção de Sérgio Moriconi, ainda aluno do curso de Arquitetura na época.

${ }^{47}$ Sua tradução seria "momento revelador". Termo utilizado por Vladimir Carvalho em "Cinema candango: matéria de jornal", 2002, p. 84. 

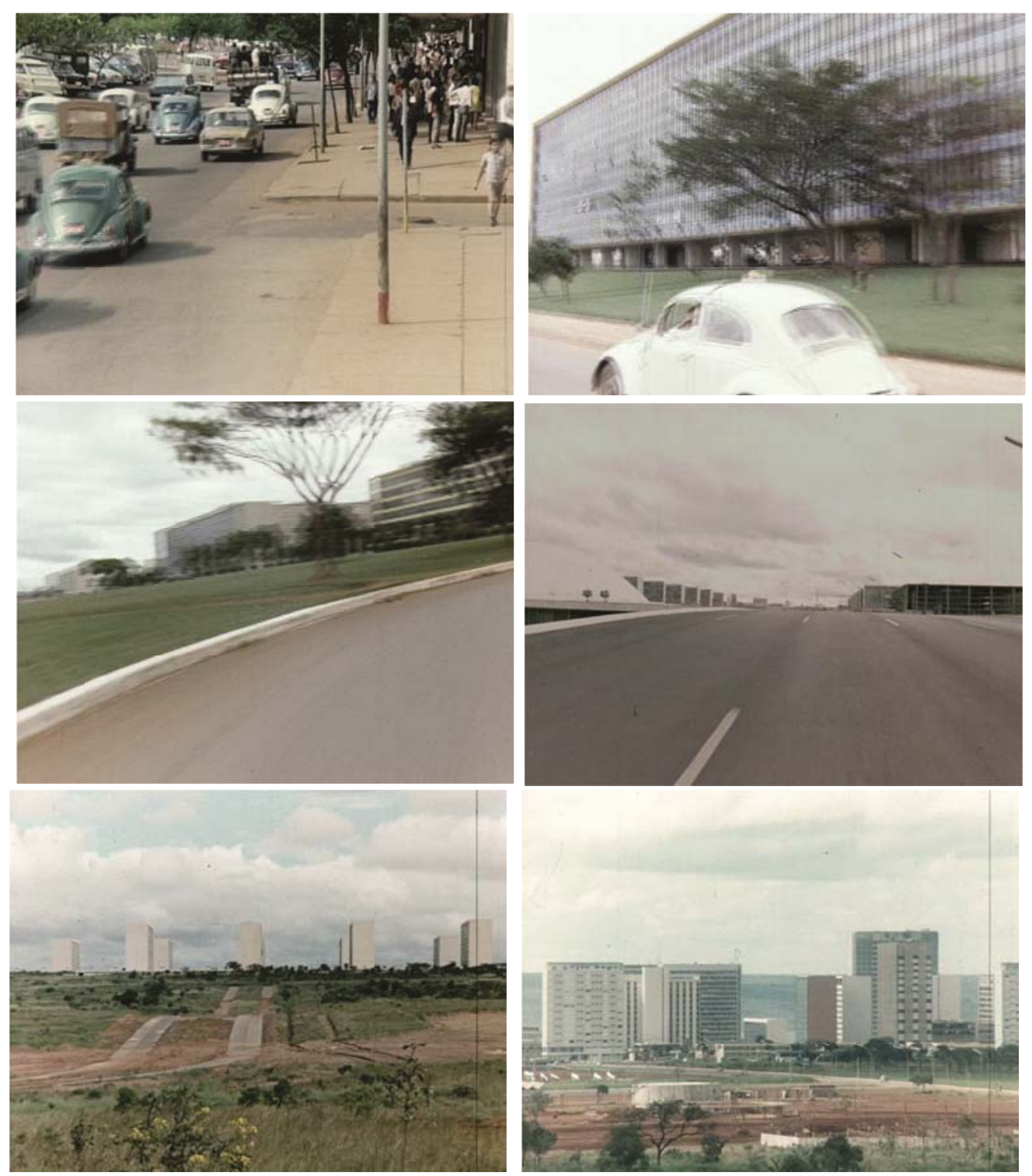

Figura 62: Still do filme "Brasília, ano 1o", de Geraldo Sobral Rocha, 1970.

Sobre o filme "Brasília, ano 10" ${ }^{\triangleright 10}$, de Geraldo Sobral Rocha, que comemora os dez anos da cidade, nota-se a permanência da intenção de explicar o funcionamento e suas diferenças da circulação e setorização da capital em relação às outras cidades, utilizando os mesmos percursos pelos eixos rodoviário e monumental, a bordo do automővel (Figura 62). A maneira como a sociedade se organiza em cidades é a questão principal e intercala trechos de textos de Henri Lefebvre, Pero Vaz de Caminha e Lucio Costa para discorrer sobre a maneira de habitar no Brasil pré e póscolonial.

Percebe-se um movimento de desaceleração do ritmo veloz imposto pela modernidade, quando depois de um período de busca de orientação, da apreensão do "modo de usar" da cidade, a câmera diminui seu foco para perceber os corpos, os sotaques e as paisagens. $\mathrm{O}$ momento político 
certamente corroborou com o clima de suspensão e lentidão, descobrindo a fase da "fabulação", como descrito por Milton Santos:

\footnotetext{
A força é dos "lentos" e não dos que detém a velocidade elogiada por um Virilio em delírio, na esteira de um Valéry sonhador. Quem, na cidade, tem mobilidade - e pode percorrê-la e esquadrinhá-la - acaba por ver pouco, da cidade e do mundo. Sua comunhão com as imagens, frequentemente pré-fabricadas, é a sua perdição. Seu conforto, que não desejam perder, vem exatamente do convívio com essas imagens. Os homens "lentos", para quem tais imagens são miragens, não podem, por muito tempo, estar em fase com esse imaginário perverso e acabam descobrindo as fabulações. (SANTOS, 1996 apud JACQUES, 2012, p. 280)
}

Entre imagens de uma corrida de automóveis no eixo monumental, a corrida dos atletas com a tocha olímpica e uma partida de futebol, captase uma cidade viva, pessoas nas calçadas, nas quadras, nos automóveis. Porém, em sua narração e imagens, percebe-se uma mudança que será a marca da representação de Brasília nesse período: "Se se desejar uma representação de cidade ideal e das suas relações com o universo, não é entre os filósofos que se deve procurar essa imagem, e sim entre os autores de ficção científica" ${ }^{\prime 4}$, ao retratar paisagens amplas, vazias ou de uma arquitetura desarrazoadamente monumental.

Dois filmes que mereceram destaque na época foram: "Carolino Leobas" (Sergio Moriconi, 1978) e "Seu Ramulino" (Marcos Mendes, 1979), considerados pelo cineasta, crítico e historiador de cinema Jean-Claude Bernadet como parte de uma nova tendência do documentário brasileiro. Moriconi (2012, p. 137) explica que "a tese de Bernadet era de que o documentário teria se deslocado de uma perspectiva sociológica para uma perspectiva antropológica, na qual é privilegiada a visão do personagem ou do interlocutor" e não a do diretor. Já apontando a influência das novas linguagens cinematográficas, como o cinema-verité e o nosso Cinema Novo, que procuravam mostrar a realidade a partir dos olhos de quem a vive, sem que o diretor interfira ou a interprete.

A tese defendida pelos principais professores da UnB era a vocação da cidade para o documentário, pelo fato de Brasília estar fora do eixo RioSão Paulo e assim, dos centros econômicos e culturais do país. No entanto, a ideia será enfraquecida pela produção cada vez maior de filmes de ficção, inspirados pelas características físicas e simbólicas que a cidade oferece.

O Festival de Cinema de Brasília, que teve sua primeira edição em 1965 como "I Semana do Cinema Brasileiro", passando a adotar o nome "Festival de Brasília do Cinema Brasileiro" no ano de 1967, foi um território livre da censura entre 1975 e 1980, e era palco de encontros e

\footnotetext{
${ }^{48}$ Trecho da narração de "Brasília, ano 10", de Geraldo Sobral Rocha.
} 
discussões, principalmente de contestação à ditadura militar. Outras manifestações no campo do cinema aconteceram às margens da universidade: em 1979, surge a Pedra Produções Cinematográficas, com Marcelo Coutinho, Pedro Anísio e João Facó, numa atitude pioneira na intenção de produzir filmes independentes.

A década de 1970 foi marcada pelo movimento do Cinema Marginal, com sua "estética do lixo", como resistência à ditadura militar. A sátira e a anarquia como linguagem podem ser percebidas nos filmes de Rogério Sganzerla, Julio Bressane e também em Glauber Rocha, e no caminho seguido pela Pedra Produções em Brasília, retratando o momento político através de filmes como: "Fig meu anjo - os três poderes são um só: o deles" (João Facó, 1979).

\footnotetext{
Memória e invenção, poesia e experimentação, revolução e escracho. O cinema brasileiro dos anos 1960 e 1970 viveram uma época efervescente. $O$ cinema marginal radicalizou a linguagem cinematográfica aprofundando as experiências do Cinema Novo, que começava a buscar maior contato com o público pela via de um abrandamento nas experiências estéticas. O rótulo Cinema Marginal é visto com desconfiança - e às vezes até com desprezo - pela maioria dos realizadores desses filmes. (PUPO E MACHADO, 2009).
}

A personalidade do cinema trash de Brasília tem ainda Affonso Brazza, herdeiro da "Boca do Lixo" ${ }^{49}$, movimento que em São Paulo é parte da ressureição da chanchada, com comédias eróticas, trilhando um rumo diferente do até então perseguido pelos cinemanovistas, numa mistura de humor e erotismo e numa busca por uma melhor relação cinema-público. (CALDAS e MONTORO, 2006)

Revela-se um acervo cinematográfico muito rico que retrata Brasília e suas personagens: os candangos, os migrantes, a universidade e seus mestres, os cineclubistas e admiradores, estreitando a relação entre a cidade e o cinema, tanto na produção de documentários quanto na busca por novas linguagens.

\footnotetext{
${ }^{49}$ Boca do lixo: denominou-se assim o quadrilátero da Luz, bairro de São Paulo, onde se localizavam os escritórios de distribuidores, exibidores e produtores. Inicialmente teve seu nome associado ao Cinema Marginal, mas depois passou a ser sinônimo de pornochanchada, gênero que abrigava a comédia, drama policial, suspense, terror, western e experimental. Entre 1972 e 1982 foi considerada a "Hollywood brasileira" por produzir cerca de 700 filmes. (SÁ, 2003)
} 


\title{
3.2.3 A cidade se descobre: "Brasiliários"
}

\begin{abstract}
Prenderam-me na liberdade. Mas liberdade é só o que se conquista. Quando me dão, estão me mandando ser livre. - Todo um lado de frieza humana que eu tenho, encontro em mim aqui em Brasilia, e floresce gélido, potente, força gelada da natureza...
\end{abstract}

Sou atraída aqui pelo que me assusta em mim. - Nunca vi nada igual no mundo. Mas reconheço essa cidade no mais fundo do meu sonho. O mais fundo do meu sonho é uma lucidez.

"Nos primeiros começos de Brasília", Clarice Lispector, 1970.

A década de 1980 se caracteriza pela maior aceitação do cinema nacional, pelos efeitos do "milagre brasileiro" e das intervenções estatais no cinema, na cultura em geral e que ampliaram as possibilidades de realização. No entanto, com o fim do regime militar em 1985 e o afrouxamento da censura, a economia começava a declinar e o cinema encontrava-se marcado pelo erotismo da pornochanchada. A temática política sobrevive junto à comédia erótica, principalmente nos documentários sobre greves e lutas sindicais, no início da década de 1980. Temas como o confronto com a ditadura, os danos e as consequências desse período vão alimentar o imaginário nos primeiros cinco anos desta década (CALDAS e MONTORO, 2006, p. 140-153). Merece destaque o filme "Pátria amada" (1985), de Tizuca Yamazaki, que mostra a campanha das "Diretas Já", numa crítica à adesão de muitos brasileiros à política dominante.

O surgimento de diversos cineclubes e as sessões dos cines Cultura e Brasília, sessões na Aliança Francesa e Instituto Goethe, assim como outras pequenas iniciativas como essa, "engrossariam o caldo da cultura cinematográfica na cidade” (MORICONI, 2012, p. 131). 
A Escola Parque 308 recebeu o Cineclube Nelson Pereira dos Santos, do cineclubista José Damata. Surgiram também o Cineclube do Sesc e o Cineclube Gavião da Aruc, entre outros, inclusive fora do Plano Piloto. "No final dos anos 1970, começo da década de 1980, com o país mergulhado na luta pela redemocratização, os cineclubes se apresentavam como eficaz instrumento de ação cultural e política", relata Maria do Rosário Caetano, jornalista, citada por Moriconi (2012, p. 131).

O grupo de cineastas que financiava seus filmes através da Pedra Produções Cinematográficas era fruto de uma geração que cresceu num período de repressão, fazendo um cinema compromissado com a realidade e o momento histórico que o país atravessava, numa cidade onde a política é sua pulsação. Soma-se a essa iniciativa a Candango Promoções Artísticas, criada por Claudia Pereira, Romário Schettino e Cleber Loureiro. Localizada numa sala comercial do Conic, fez desse local de efervescência cultural um de seus principais temas e locação.

O Conic é um conjunto de edifícios localizado no Setor de Diversões Sul (espelhado ao Conjunto Nacional, que fica ao Norte), e contava na época com os Cines Atlântida, o Cine Bristol, além de cinemas pornôs, boates, sex shops, livrarias, a Faculdade de Artes Dulcina de Moraes, sindicatos, artigos de umbanda, homossexuais, travestis, igrejas, o céu e o inferno (MORICONI, 2012, p. 147).

Aí foram filmados: "Obscena” (João Lanari, 1986), "Denis' Movie" (João Lanari, 1996) e "Subterrâneos" ${ }^{\triangleright " 1 ~(J o s e ́ ~ E d u a r d o ~ B e l m o n t e, ~ 2003) . ~ A i n d a ~}$ sobre o Conic, Moriconi escreve que:

A periferia cada vez maior do que o Plano Piloto, núcleo básico do projeto urbanístico de Lucio Costa. O Conic e todo o setor de diversões sul, incluindo a rodoviária eram o microcosmo de uma cidade praticamente invisível aos moradores das Asas e do Lago Sul e Norte. Polo de atração irresistível por sua dinâmica cultural, o Conic seria objeto de interesse de diferentes gerações de cineastas, de Lanari e Belmonte. (MORICONI, 2012, p. 153)

O curta-metragem "Taguatinga em pé de guerra" (Armando Lacerda, 1982), realizado pela Candango, apresentou pela primeira vez uma cidadesatélite como tema central, e percebe-se um novo olhar para a cidade, como fez o jornalista e diretor João Lanari em "Mínima cidade" ${ }^{{ }^{2}}$ (1984) ao mostrar um passeio pelas vias $\mathrm{W}_{4} \mathrm{e} \mathrm{W}_{5}$, seus estacionamentos $\mathrm{e}$ estruturas de abastecimento, numa visão não monumental da cidade (Figura 63). O fez também "Brasiliários" ${ }^{13}$ (Zuleica Porto e Sergio Bazi, 1986), ao retratar a Brasília percebida por Clarice Lispector em seus textos de 1962 e 1974, "tão artificial quanto deveria ter sido o mundo quando foi criado", quase uma ficção científica. 

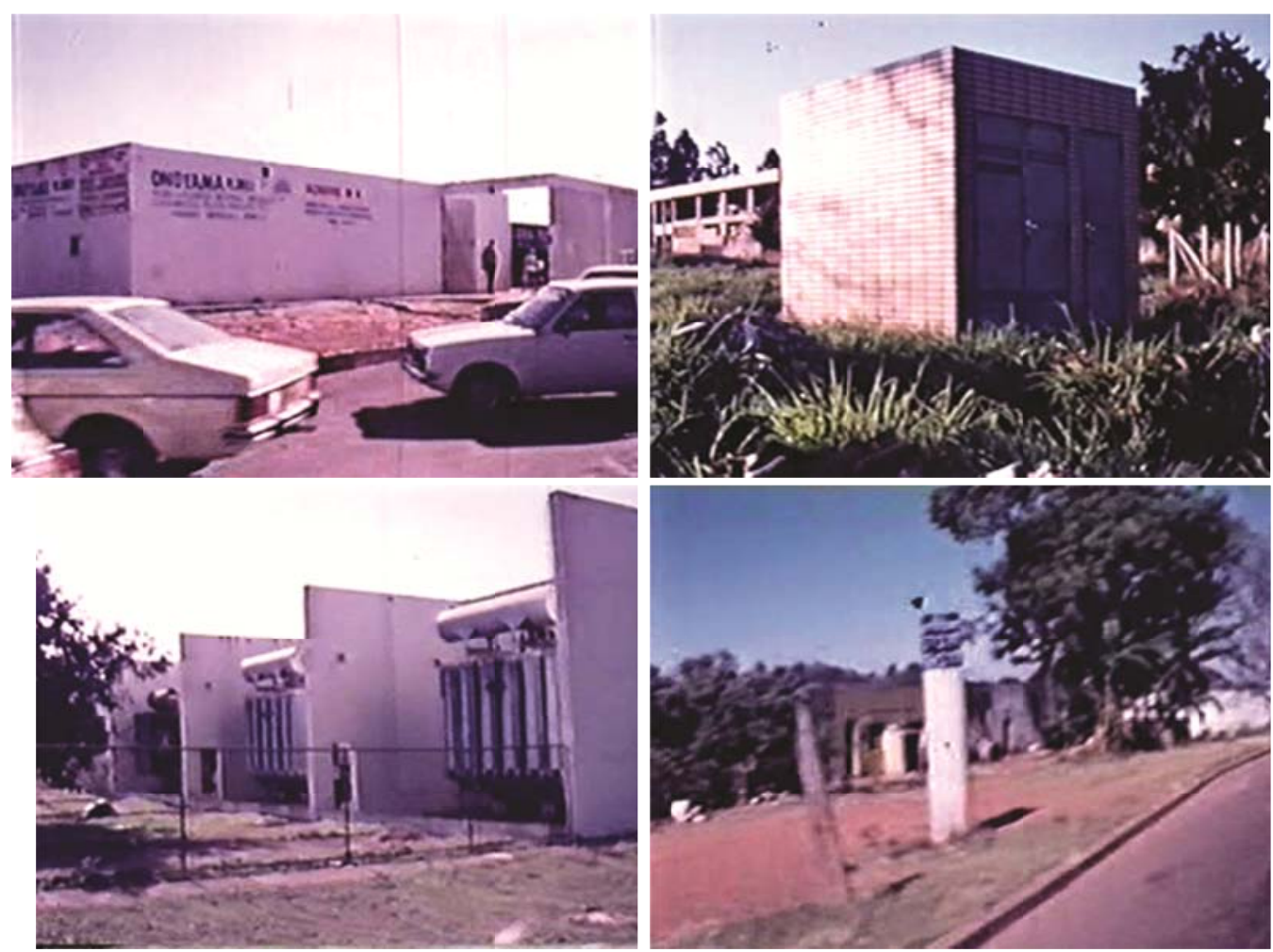

Figura 63: Still do filme "Mínima cidade”, João Lanari, 1984. Fonte: acervo do diretor.

São percursos pela Brasília não oficial, pelos cantos, pelos territórios abandonados, impessoais, aqueles que o habitante comum, o homem ordinário é capaz de perceber em seu cotidiano, mas que não passa por eles sem ter algum impacto ou incômodo. São imagens de Brasília não planejada, espontânea, mas ainda não humanizada, não há pessoas, apenas ruas e carros.

"Mínima cidade" é um filme antimonumental, rodado naqueles pequenos centros de abastecimento que existiam, e que ainda existem, nos fundos das quadras 700 da Asa Sul e que serviam para garantir uma crença ingênua no sistema de abastecimento que seria capaz de ser feito sem intermediários, com o público comprando diretamente do produtor, que tinha sua horta ali mesmo. Era algo tão inviável quanto a ideia de a $\mathrm{W}_{2}$ ser a frente do comércio e a $\mathrm{W}_{3}$ ser apenas via de escoamento. Eram premissas modernistas ingênuas e até mal intencionadas, um erro crasso. (LANARI in RIBONDI, PEREIRA e SCHETTINO, 2012)

Sobre "Brasiliários" (Figura 64), a diretora Zuleica Porto responde à pergunta: "Brasiliários é um filme nu, seco e despojado. Essses três adjetivos se aplicam à Brasília da época, início dos anos 8io?” (RIBONDI, PEREIRA e SCHETTINO, 2012, p. 134), publicada no livro "O sonho candango: memória afetiva dos anos $80 "$ : 

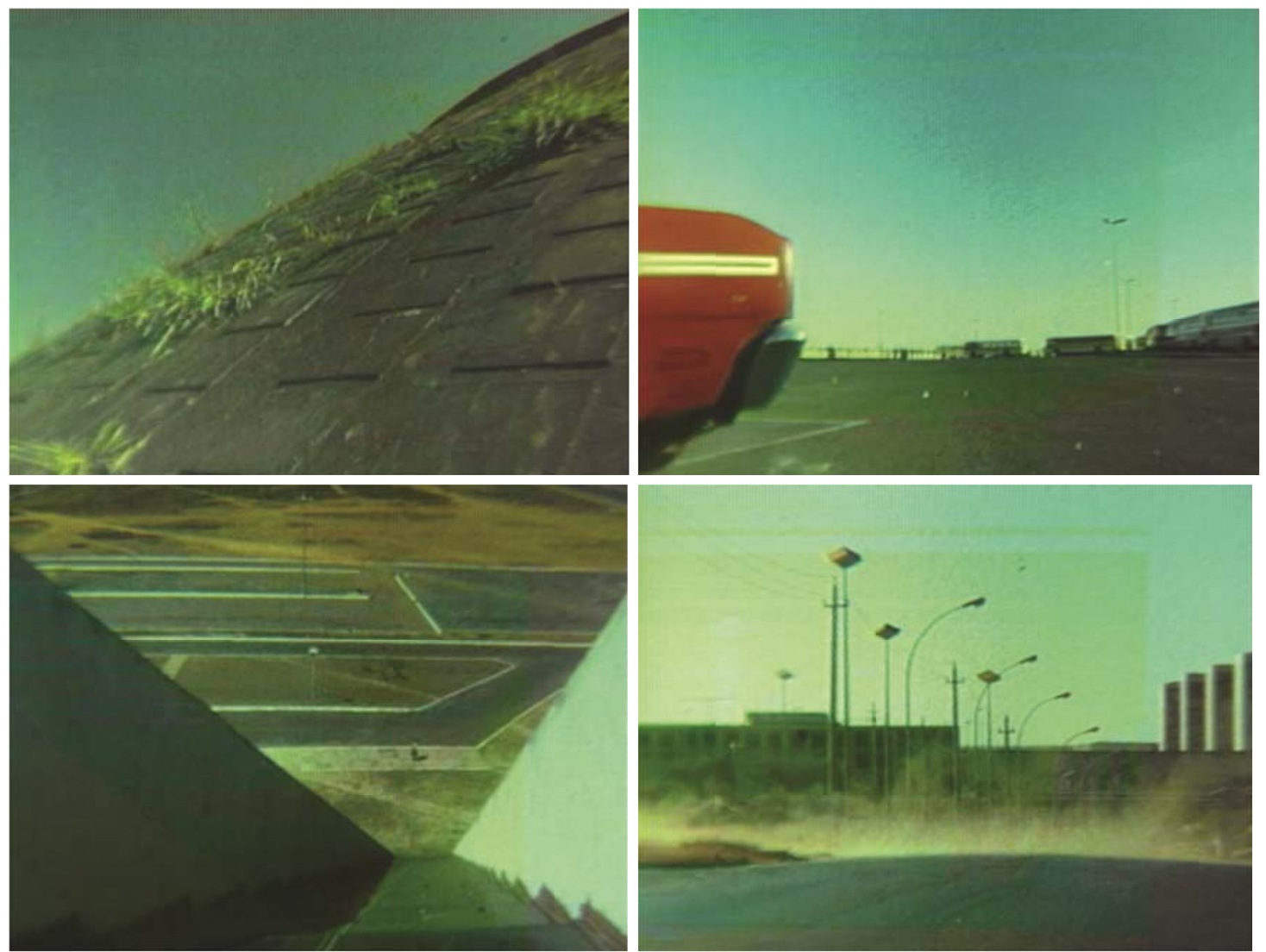

Figura 64: Still do filme "Brasiliários", Sergio Bazi e Zuleica Porto (1986). Fonte: CPCE-UnB.

Sim, principalmente porque na época que foi filmado, em julho, havia secura nos dois sentidos. A gente queria Brasília vazia, silenciosa, despojada. Era como se já estivéssemos prevendo que Brasília ia perder este modelo, este jeito de ser, porque as pessoas vão parando de querer que seja assim (idem, p. 134).

Sérgio Bazi, que também o dirigiu, comenta que: "O que a gente queria nesse filme era mostrar uma Brasília diferente, mais particular, com imagens mais inesperadas da cidade, algo que não fosse a Brasília oficial". E indica que, nessa época, uma identidade brasiliense começava a se formar, mas, na opinião do diretor, não duraria muito tempo: "Brasília tinha mais identidade cultural, mais identidade artística, o que foi se diluindo com o tempo. As bandas de rock dos anos 8o, por exemplo, eram a cara da cidade" (RIBONDI, PEREIRA e SCHETTINO, 2012, p. 140). No entanto, essa impressão não é unânime e o que se percebe é que dos anos 1980 em diante a cidade teve um crescimento acelerado, principalmente pelo surgimento de novas cidades-satélites, que começavam a exercer forte pressão no Plano Piloto. A pureza do projeto e sua utopia começam a ser contaminados pela pressão e reivindicação identitária da sua periferia. Já a impressão de Jacques Cheuichi, fotógrafo de "Brasiliários", propõe um novo ponto de vista: 
O filme tem delicadeza, uma homenagem a Brasília, um voo na terra da cidade.É um voo que não vê de cima, vê aqui de baixo mesmo. Foi isso que ficou pra mim desta experiência: um voo baixo, bem em cima da terra. Brasiliários lambe Brasília. (RIBONDI, PEREIRA e SCHETTINO, 2012, p. 144)

Segundo o crítico e curador de cinema Carlos Alberto Mattos, "o florescimento do cinema brasiliense, ao longo das décadas de 1970 e 1980, levou à superação da fase oficialista e ao advento de uma postura mais crítica e inquisitiva a respeito das grandes perguntas que a cidade colocava" (apud SÁ, 2003, p. 10). A relação com o vazio é de estranheza, mas ao mesmo tempo demonstra sua potência evocativa similar ao que Solà-Morales (1995) descreve como terrain vague: "entre a ausência de uso, de atividade e o sentido de liberdade, de expectativa. Vazio, portanto, como ausência, mas também como promessa, como encontro, como espaço do possível, expectativa" ${ }^{50}$.

Em "O sonho não acabou" (1982), de Sergio Rezende, que mostra a geração de jovens de Brasília buscando sentido na vida após a repressão que emudeceu o país desde os anos 1960, esses jovens perambulam, deambulam pela cidade enquanto a descobrem e descobrem a si mesmos

Figura 65). Os espaços amplos, assim como a juventude, representam uma ausência de limites: "esse sentimento quase oceânico, para dizer com uma expressão de Sigmund Freud, é precisamente a mensagem que contém expectativas de mobilidade, vagabundagem, tempo livre, liberdade" (SOLÀ-MORALES, 1995). São os percursos erráticos, nos espaços banais da cidade, buscando a experiência da diferença, numa condição de afastamento do que é familiar e confronto com os vários outros urbanos, que Jacques (2012, p. 30) chama de errar: "errar tanto no sentido de vagar, vagabundear, quanto no da própria efetivação do erro - de caminho, de itinerário, de planejamento". Os percursos desses jovens pela cidade, em seus espaços "vagos", "do vagar", no filme de Sergio Rezende representam essa experiência errática, uma experiência urbana da alteridade, de encontro com o outro para descobrir a si próprio e a cidade.

O tombamento da cidade em 1987 pela Unesco serve de inspiração para "Brasília: a última utopia" (1989), um longa-metragem com seis episódios, seis diferentes declarações de amor a Brasília, tratando exclusivamente de temas relacionados à cidade, "a sua paisagem natural,

${ }^{50}$ Tradução livre: "la relación entre la ausencia de uso, de actividad y el sentido de libertad, de expectativa es fundamental para entender toda la potencia evocativa que los terrain vague de las ciudades tienen em la percepción de la misma en los últimos años. Vacío, por tanto, como ausência, pero también como promesa, como encuentro, como espacio de lo posible, expectación" 
os seus mitos, a sua mestiçagem, os seus gritos e agruras, os seus momentos e especialmente o seu povo" (MONTORO, 2012, p. 202). Buscou atualizar as temáticas já abordadas em obras das décadas anteriores, procurando compreender sua simbologia em novo contexto. "Mas, 21 anos depois do $\mathrm{AI}-5$, o estrago já estava feito. Brasília tinha se tornado outra coisa. Híbrida, multifacetada, inapreensível aos olhos de quem viveu a cidade em sua época heroica" (MORICONI, 2012, p. 155).
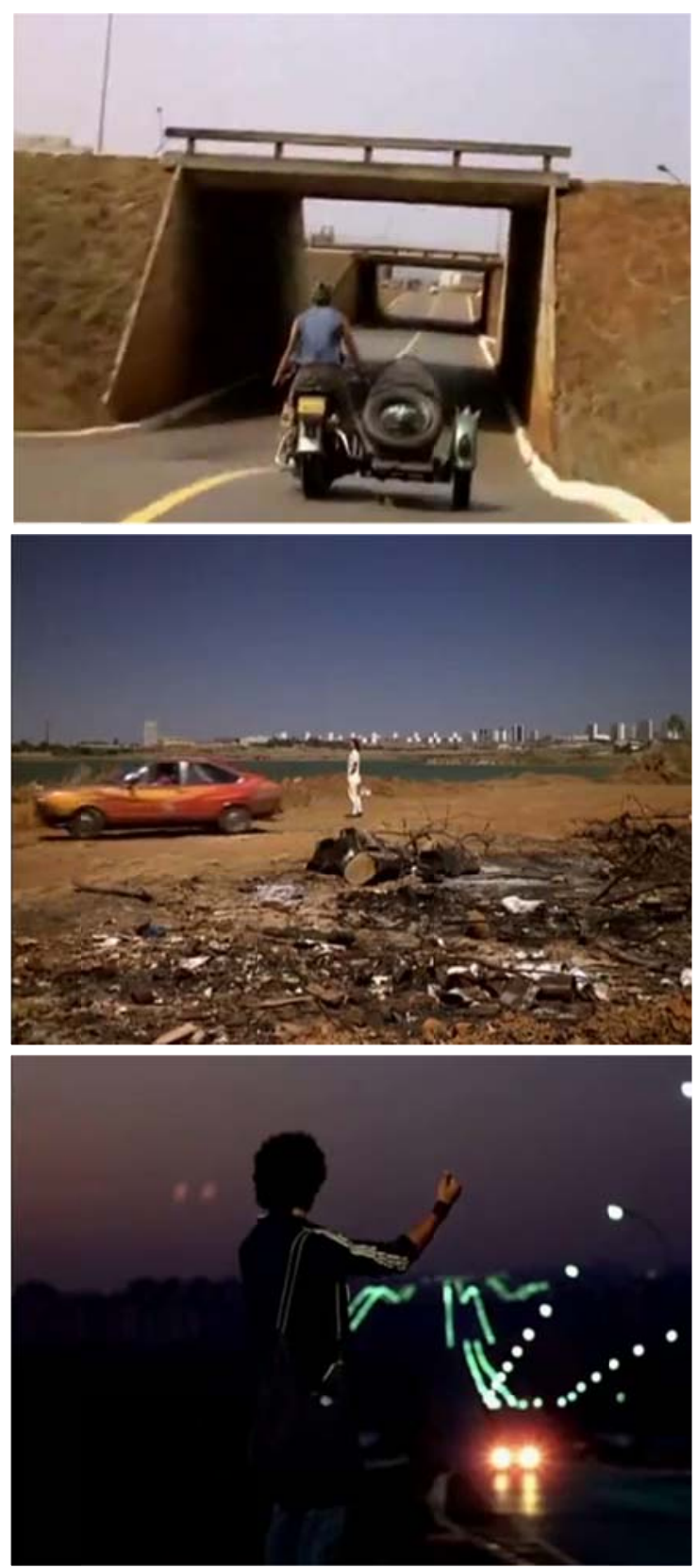

Figura 65: stills do filme "O sonho não acabou", de Sergio Rezende, 1982. Fonte: Embrafilme 
No final da década de 1980, com a retomada do processo democrático e eleições para presidente, muitos realizadores e produtores passaram a atuar nas campanhas políticas, encontrando um novo e potencial campo de trabalho. A criação do Centro de Produção Cultural Educativa (CPCE), ligado à UnB, em 1986, do Fundo de Apoio à Cultura (FAC), em 1991, e a criação do Polo de Cinema, em 1993, dariam impulso para o mercado de produção local. 


\subsubsection{Crise de identidade: "A terceira margem do rio"}

Nosso pai entrou na canoa e desamarrou, pelo remar. E a canoa saiu se indo - a sombra dela por igual, feito um jacaré, comprida longa.

Nosso pai não voltou. Ele não tinha ido a nenhuma parte. Só executava a invenção de se permanecer naqueles espaços do rio, de meio a meio, sempre dentro da canoa, para dela não saltar, nunca mais. A estranheza dessa verdade deu para estarrecer de todo a gente. Aquilo que não havia, acontecia. Os parentes, vizinhos e conhecidos nossos, se reuniram, tomaram juntamente conselho.

"A terceira margem do rio", Guimarães Rosa.

O título do capítulo tomou emprestado o nome do filme "A terceira margem do rio", de Nelson Pereira dos Santos, filmado em 1994, que reproduz o conto de João Guimarães Rosa de 1962. Esse conto retrata o isolamento de um homem que decide viver em uma canoa e a solidão e os questionamentos que essa atitude provoca em sua família. $\mathrm{O}$ capítulo trata da dinâmica do vazio presente na cidade e sentido por seus habitantes.

A década de 1990 tem uma produção resultante do Curso de Cinema da Universidade de Brasília funcionando no Departamento de Comunicação ${ }^{51}$, e começa a mostrar uma amplitude maior em termos de gêneros. A criação do Polo de Cinema e Vídeo do Distrito Federal, em 1993, com o objetivo de fomentar a produção local e nacional permite a realização de "A terceira margem do rio" (Nelson Pereira dos Santos, 1994), "Louco por cinema” (André Luis de Oliveira, 1994) e "O cego que

\footnotetext{
${ }^{51}$ Com a redemocratização da UnB, iniciada em 1984, o Centro de Produção Cultural e Educativa e a Rádio UnB ligam-se ao Departamento de Comunicação. Em 1989, o projeto de criação da Faculdade de Comunicação é aprovado e entra em vigor. Em 2010, é criado o curso de Comunicação Organizacional. Hoje, a FAC conta com dois departamentos: o de Jornalismo e o de Audiovisual e Publicidade, e o curso de Comunicação Organizacional, com 62 professores e 995 alunos. Fonte:

http://fac.unb.br/5oanos
} 
gritava luz" (João Batista de Andrade, 1996), todos coproduzidos pelo CPCE-UnB (Centro de Produção Cultural Educativa), o que coloca a universidade sempre em participação com as iniciativas de produção cinematográfica na capital. Segundo Moriconi (2012, p. 181), os anos 90 foram "cruciais para consolidar as bases para a afirmação do cinema de Brasília", pela grande participação de estudantes e estagiários ligados ao CPCE, formando e consolidando a carreira de vários cineastas que configurariam a chamada "Geração Brasília”, entre eles, José Eduardo Belmonte.

Tania Montoro (2012) sinaliza que a contradição é o elemento dinâmico e fundador do imaginário de Brasília, tanto dos filmes dos tempos de sua fundação como nos contemporâneos da nova safra, realizados nas últimas décadas pelos cineastas da "Geração Brasília". A década de 1990 viu emergir um questionamento de sua identidade que se tornaria típico e que poderia ser classificado como uma crise de pertencimento, o que, segundo Raquel Sá (2003, p. 10), se traduz no "sentimento de que a imensidão do horizonte do cerrado pressupõe não abundância, mas certo vazio, um déficit de comunicação".

"Brasília, ano 35" (Waldir de Pina, 1995) foi uma homenagem à cidade em comemoração a seu aniversário e utiliza a "Sinfonia da Alvorada", composta por Vinicius de Morais e Tom Jobim, como roteiro. $\mathrm{O}$ filme se inicia com imagens do cerrado, da natureza que começa a ser povoada, e o sentimento de solidão está presente:

No princípio era o ermo

Eram antigas solidões sem mágoa.

$\mathrm{O}$ altiplano, o infinito descampado

No princípio era o agreste:

O céu azul, a terra vermelho-pungente

E o verde triste do cerrado.

Eram antigas solidões banhadas

De mansos rios inocentes

Por entre as matas recortadas.

Não havia ninguém. A solidão

(...)

Em "Brasília, um dia em fevereiro" ${ }^{>14}$ (1996), Maria Augusta Ramos mostra a solidão sentida pelos habitantes de Brasília, de classes sociais diversas, através dos amplos espaços vazios da cidade e da sua arquitetura. Já em "Feliz aniversário, Urbana" (Betse de Paula, 1996), a personagem de nome Urbana, uma bancária solitária que tem um único desejo no dia de seu aniversário: dormir. Mas a agitação da vida urbana não permite e a personagem percorre uma saga até que consegue encontrar o local ideal para dormir - a agência bancária (Figura 66). 


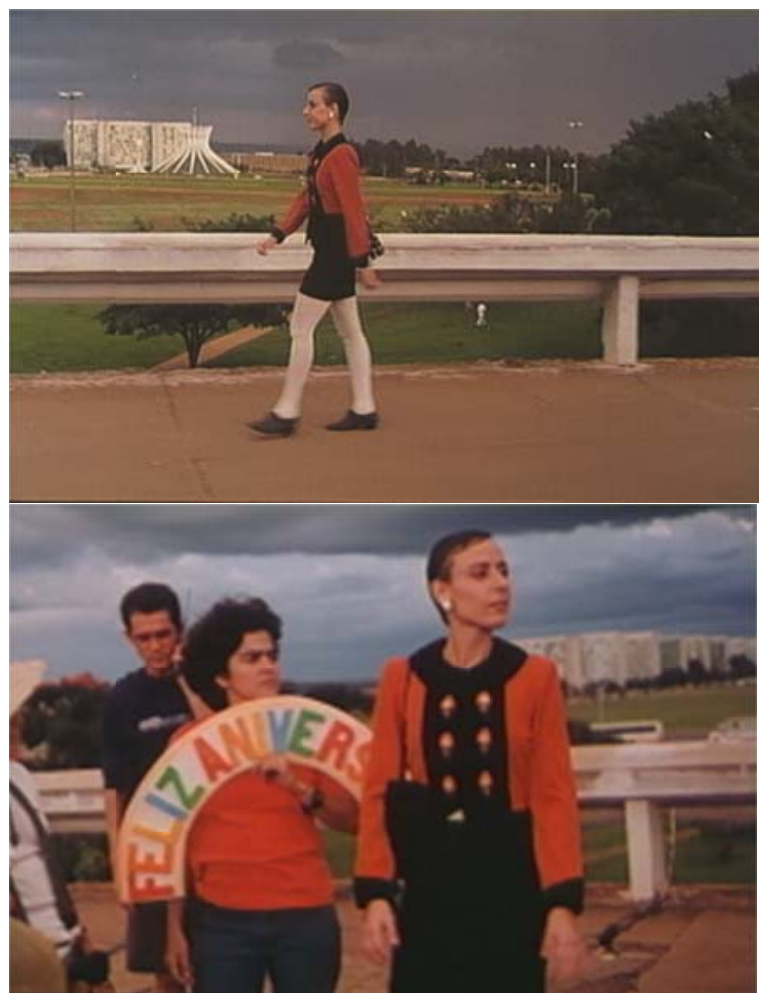

Figura 66: Stills de "Feliz aniversário, Urbana", de Betse de Paula 1996. Fonte: CPCE-UnB.

Mas é a vida cotidiana que passa pelos monumentos, o vazio é preenchido por memórias, pelos habitantes que trabalham, circulam e vivem a cidade e seus percursos.

Brasília, longe da sua amplidão, solidão e espaços generosos é, de alguma forma, humanizada nos filmes da "Geração Brasília" - ao ser emolduradia por paisagens humanas que entrecruzam territórios físicos e simbólicos, eixos e paralelas que confinam, segregam e separam. Notabiliza-se a profusão de tipos que convivem na zona central da cidade no cruzamento da rodoviária com o Plano Piloto e as demais cidades-satélites (MONTORO, 2012, p. 204).

Ficam perceptíveis algumas convergências temáticas nesse período: a questão da violência urbana, as desigualdades, a singularidade da paisagem e arquitetura, a política e a diversidade culturall. A temática e a linguagem se pluralizam. 

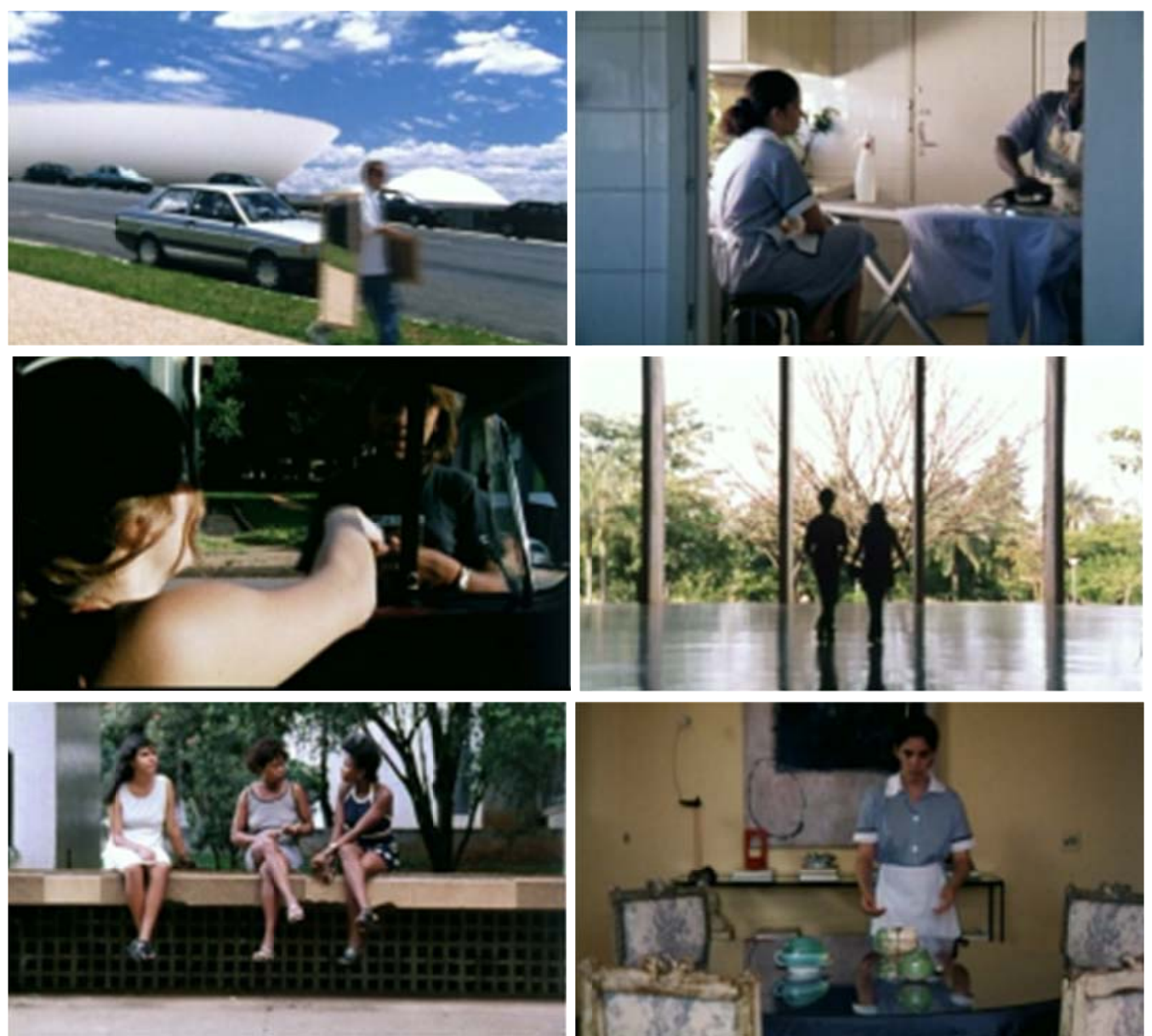

Figura 67: Stills do filme "Brasília, um dia em fevereiro", Maria Augusta Ramos, 1996. Fonte: acervo particular da diretora. 


\title{
3.2.5 Da periferia ao centro: "A cidade é uma só?"
}

\author{
Vamos sair da invasão, você que tem um bom lugar pra morar, \\ nos dê a mão, ajude a construir nosso lar. Para que possamos \\ dizer juntos 'A cidade é uma só! \\ “A cidade é uma só?", Adirley Queirós, 2011.
}

No Festival de Brasília do Cinema Brasileiro surgem várias mostras e prêmios que visavam a aumentar a visibilidade da produção brasiliense, como o Troféu da Assembleia Legislativa, a mostra Curta Brasília e sessões retrospectivas como a que aconteceu na edição de 1997, trazendo filmes brasilienses de 1965 a 1995. Algumas universidades do Distrito Federal passaram a incluir disciplinas de cinema em suas grades e surgiram cursos específicos em espaços culturais. A prática audiovisual também passou a transbordar para além do Plano Piloto, e surgem diversos cineastas atuando nas cidades-satélites. A Mostra de Taguatinga, criada em 1998, foi importante por privilegiar e revelar os primeiros filmes de jovens cineastas independentes.

Nesta década, o cineasta José Eduardo Belmonte, após dirigir vários videoclipes, curtas-metragens e passar por um período trabalhando no CPCE, produz "Subterrâneos" (2004), longa-metragem filmado no Conic (Figura 68). O filme mostra esse microcosmo da cidade, ao mesmo tempo em que faz uma referência à própria crise e dúvida de como se referir e retratar este lugar. Mas é em “A concepção" ${ }^{15}$ (Figura 69), de 2005, que Belmonte retrata seu desencanto com a cidade, quando apresenta um grupo de jovens que criam a doutrina "concepcionista", uma atitude de "total desapego do eu, da memória, de ser uma pessoa nova a cada dia", como uma "reação à mediocratização da cidade, da inconformidade com o surgimento de uma elite política indigna e mancomunada com salteadores do poder". Esses jovens mostram a crise de identidade, "uma fantasia delirante sobre o desespero de não ter uma identidade ou ter de construir suas identidades numa cidade conspurcada por uma realidade exterior corrompida e hostil". (BELMONTE apud MORICONI, 2012, p. 235) 

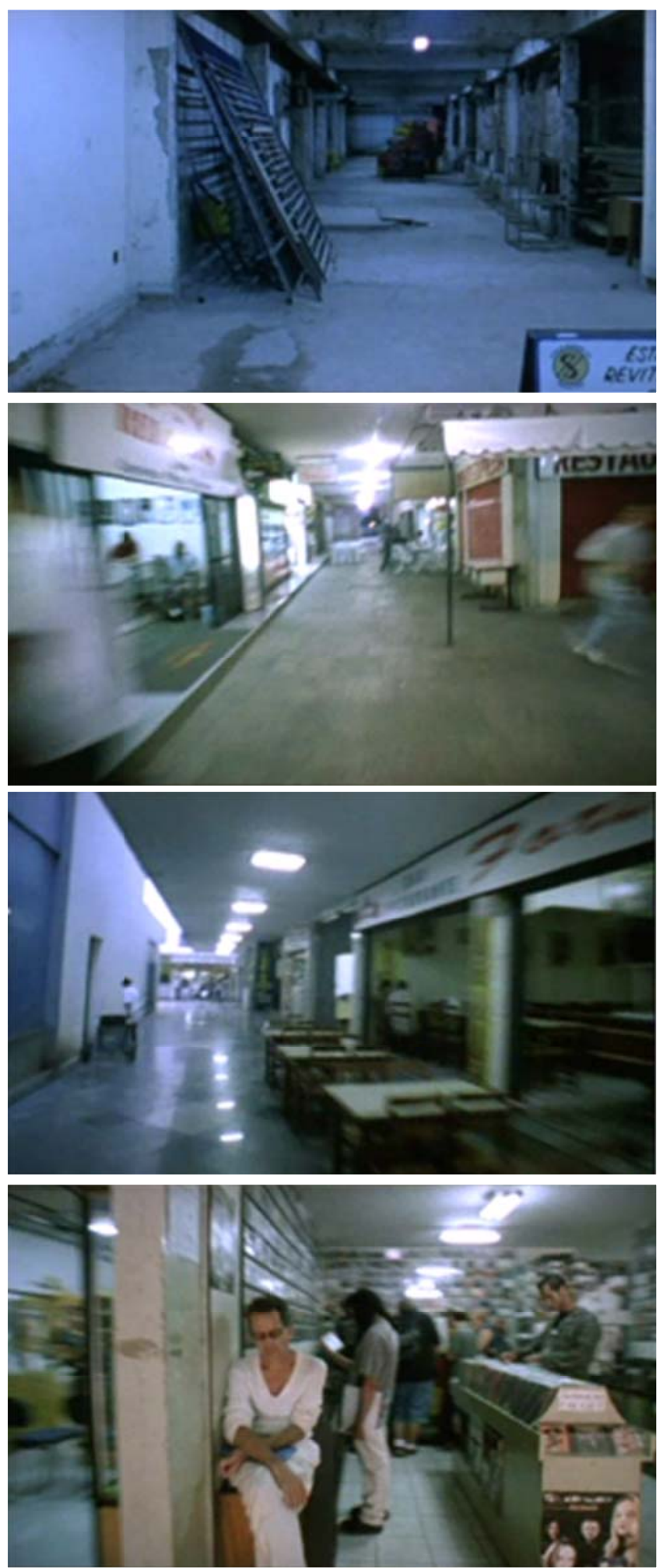

Figura 68: Stills do filme "Subterrâneos", José Eduardo Belmonte, 2003. Fonte: acervo particular do diretor. 
Belmonte realiza em "A concepção" um percurso cinematográfico que se assemelha ao que os situacionistas chamavam de "construção de situações", ou seja, o "momento da vida, concreta e deliberadamente construído pela organização coletiva de uma ambiência unitária e de um jogo de acontecimentos". Os personagens, todos jovens, criam e recriam identidades enquanto derivam pela cidade, ou enquanto permanecem trancados no ambiente do apartamento: inventando e vivendo uma teoria "concepcionista", um jogo em que a cada dia uma nova identidade deve ser assumida, e deve durar 24 horas, assemelhando ao texto-manifesto Internacional Letrista de 1954:

A construção de situações será a realização de um grande jogo deliberadamente escolhido; a passagem de um ao outro desses cenários e desses conflitos em que os personagens de uma tragédia morreriam em vinte e quatro horas. Mas o tempo de viver não faltará mais. Uma crítica do comportamento, um urbanismo influenciável, um técnica de ambiências devem se unir a essa síntese, nós conhecemos os seus primeiros princípios. É preciso reinventar em permanência a tração soberana que Charles Fourier chamava de livre jogo das paixões. (apud JACQUES, 2012)

Tanto em "Subterrâneos", como em "A concepção", percorrer a cidade, ou vagar por ela faz parte de uma experiência de descobrimento, de alteridade, de encontro com o urbano e com o outro. Não é por acaso que os espaços são periféricos, marginais, subterrâneos, e que o outro é sempre um estranho. Há uma curiosidade pela estranheza do outro e do lugar.
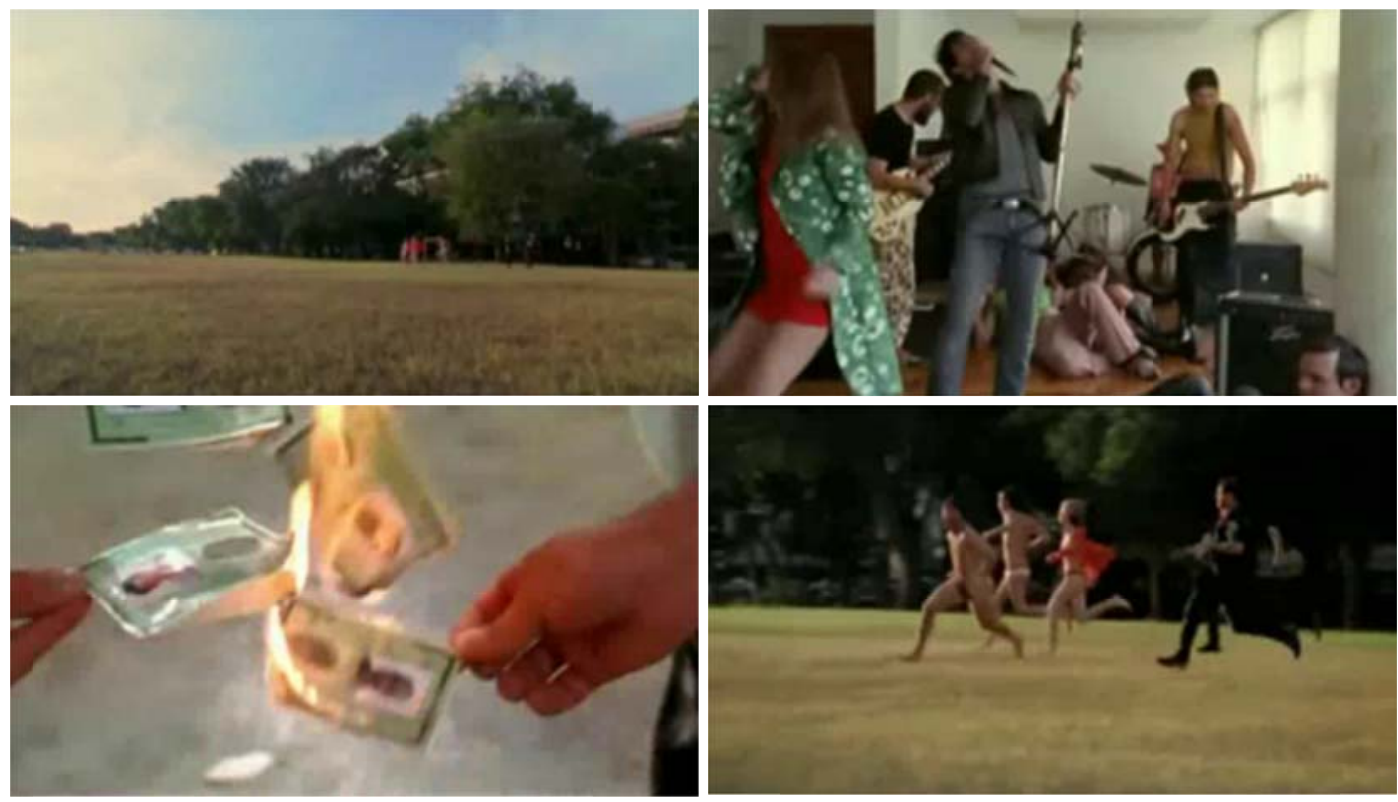

Figura 69: Stills do filme “A concepção”, José Eduardo Belmonte, 200!5. Fonte: acervo particular do diretor. 
Ao final da década de 196o, verificou-se que inúmeras favelas, as "invasões", e acampamentos de construtoras, tidos como "localidades provisórias", já contavam com cerca de 82 mil habitantes e ocupavam territórios estratégicos nas proximidades do Plano Piloto. Na década de 1970 foi instituída a Campanha de Erradicação de Invasões a CEI, que entre 1971 e 1972 cadastrou os barracos existentes nas vilas periféricas ao Núcleo Bandeirante e no Plano Piloto, transferindo posteriormente sua população para novas localidades. Esse episódio está narrado em "A cidade é uma só?" ${ }^{>16}$ (Adirley Queirós, 2011), filme que mostra a recuperação na memória, e em fontes documentais dessa parte da história (Figura 7o). No período retratado no filme, Brasília se consolidou como capital administrativa do país e, no sentido da preservação do que foi planejado, ocorreram diversas tentativas de afastar e controlar o fator de aglomeração que se formava inevitavelmente em torno do Plano Piloto. Hoje a pressão das cidades-satélites, distantes de 20 a 30 quilômetros do Plano Piloto, com $74 \%$ da população total do DF somando $80 \%$ de sua população economicamente ativa, cria uma polaridade que começa a transformar e alterar áreas significativas do Plano Piloto. (SANDOVAL e SABOIA, 2012)
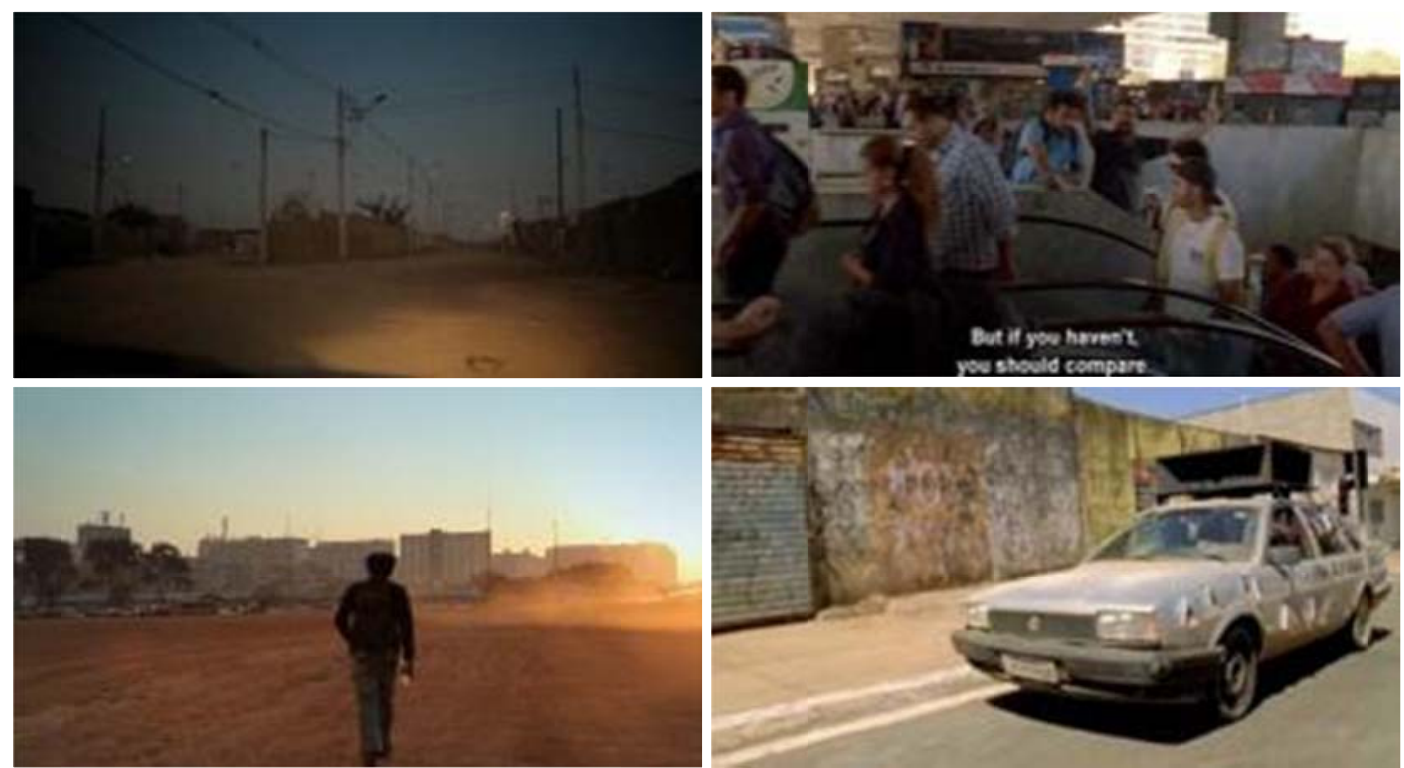

Figura 7o: Stills do filme “A cidade é uma só?", Adirley Queirós, 2ю11. Fonte: acervo particular do diretor.

Adirley Queirós, cineasta da Ceilândia, cidade-satélite, produz "Rap, o canto da Ceilândia" (2005), "Dias de greve" (2009) e "A cidade é uma só?" (2011), filmes que mostram a força da voz da cidade-satélite, através das manifestações culturais, colaborando na desconstrução dlo mito fundador da cidade coletiva e igualitária, ao mostrar sua realidade e de sua 
população. Percebe-se, assim mesmo, a preocupação pela busca de identidade, representada pela relação "ser" e "não ser" de Brasília.

"Oficina perdiz" (2006), de Marcelo Diaz, e "Braxília" (2010), de Danyella Proença, são filmes que colocam um microscópio sobre alguns personagens de cidade e começam a identificar uma cultura brasiliense. Brasília já se mostra múltipla, pela diversidade de seus temas, e ao mesmo tempo poética e afetuosa ao reconhecer e valorizar sua cultura e seus personagens.

Ao analisar filmes representativos do material audiovisual que se produziu nesses $5^{0}$ anos de existência de Brasília percebe-se, desde o início, a busca pela construção de identidade no sentido de construção do lugar. Representante da história e da cultura brasileiras, Brasília teve seus espaços apropriados pelo fluxo - tanto o migratório quanto pelos percursos proporcionados pelas vias de circulação - e reflete um misto de exaltação e decepção, até encontrar-se como uma cidade, metrópole, com os mesmos problemas das outras metrópoles brasileiras.

Brasília continua despertando críticas pela sua arquitetura e desenho urbano, pela questão política e econômica e por escancarar a desigualdade social do país. As críticas, assim como as apologias, fazem parte do discurso fundador da capital e a permeiam até nossos dias. Ficam visíveis nos filmes, nos discursos políticos, na fala dos brasileiros e estrangeiros, em estudos, pesquisas, pintura, fotografia, entre outros. Brasília fez-se dialeticamente antagônica, assim como a utopia que a inspirou.

Brasília não nos deixa esquecer a utopia. Toda vez que contemplamos ou discutimos esta cidade, dificilmente conseguimos circunscrever nosso olhar ou nossa conversa a tópicos estritos da arquitetura e urbanismo. Somos conduzidos (...) ao horizonte da utopia, dos projetos de transformação social. E a passar em revista, de modo crítico e/ou com anseios visionários, relações entre a dimensão utópica do pensar e do fazer - e os constrangimentos colocados pela contextura histórico-social e a realidade ordinária de todos os dias. A simples e clara existência de Brasília, em si mesma, incita a reflexão e a autorreflexão. Faz-nos pensar o Brasil e nosso lugar no Brasil. (RISÉRIO, 2012, p. 299)

A lógica do urbanismo racionalista surgida da união com o pensamento da indústria, que poderia favorecer a criação de uma sociedade organizada arquitetônica e urbanisticamente de acordo com os novos tempos, e a ajuda das teorias positivistas que contagiaram o Brasil República, a ordem e o progresso deveriam estar presentes em Brasília "enquanto cidade planejada", que, contraditoriamente, fazia com que o Brasil real não coubesse em Brasília, mas "que de fato, essencialmente, 
permaneceria integralmente o mesmo, inclusive nela". (BICCA, 1985, p. 211)

Percebe-se nos primeiros materiais audiovisuais que agregam o discurso político fundamental para o sucesso da empreitada de Brasília como uma narrativa do projeto moderno de construção do "novo", do desenvolvimento e organização espacial, como sentido totalidade.

Já na década seguinte à sua inauguração, ao mesmo tempo em que se percebe a tentativa de afirmação da sua cultura, o país passa pelo golpe da tomada do poder pelos militares. É quando a cidade testemunha e denuncia diversos episódios que marcariam sua história para sempre. Com o fim do regime militar e o afrouxamento da censura, mesmo em meio a uma forte temática política, os filmes mostram os percursos não oficiais de Brasília, os territórios abandonados, impessoais, imagens de Brasília não planejada, espontânea, e... vazia. E é possível perceber uma crise de pertencimento, uma crise de identidade que fica manifesta nas representações da cidade.

Evidencia-se década a década a fragmentação dessa narrativa da totalidade, quando os movimentos que antes eram coletivos passaram cada vez mais a contar com iniciativas individuais. O protesto e a luta parecem ter dado lugar a uma crise e resignação, que permeia toda a década de 1990 e continua na virada do século, quando aparecem alguns pontos de resistência vindos das cidades-satélites.

A metrópole não é mais periférica ao Plano Piloto, que vem sofrendo fortes pressões. A maneira de circular pela cidade estabelece seu fluxo metropolitano, a cidade tornou-se uma aglomeração de vários núcleos contínuos antes distantes.

Nos retratos mais recentes de Brasília evidenciam-se pontos de encontro, uma conjunção de linhas que se cruzam, histórias de amor que se desenvolvem no percurso de ônibus no eixo centro-periferia; são candidatos que fazem sua campanha no fluxo da rodoviária; o afetivo poeta brasiliense que inventa outra Brasília, enquanto caminha no contrafluxo de veículos no eixo rodoviário, a cidade que é utópica "Braxília", que acontece apesar das normas e setores.

No entanto, Brasília parece sempre incorporar o paradoxo da sua realidade e sua utopia. É quando se percebe que de fato as cidades "encontram sua identidade lutando contra o passar do tempo ao capturálo através do rito e do mito" (SOLÀ-MORALES, 2003). Neste percurso até aqui, buscou-se compreender uma cidade, não somente por suas construções materializadas, por espaços fixos, mas pelos caminhos que se percorrem cotidianamente e que fazem parte de uma construção através do tempo. São fragmentos de histórias que se entrelaçam e podem servir para a compreensão de que Brasília também é uma cidade que continuou construindo, de forma satisfatória, uma peculiar forma de vida. 
Peculiar porque se trata de uma cidade especial (por seu traçado, por sua arquitetura, por sua função política, por sua localização), mas também pela incidência explícita que teve em sua realização cotidiana todo o pacote de representações precedentes, como a confirmação extrema de uma hipótese da história cultural urbana: a hipótese de que a cidade e suas representações se produzem mutuamente. (GORELIK, 2005)

O cinema de Brasília está ainda em busca do sonho, da utopia da cidade idealizada Brasília, que alimenta o imaginário e as histórias infindáveis, narra epopeias, histórias de cordel e ficções científicas. Mas ao mesmo tempo se tornou responsável pela busca de uma representação do real, a partir de suas contradições, como síntese do próprio país, numa síntese reflexiva. Assume "o sonho da urbis utópica, onde tudo está para ser construído, onde tudo deve sempre ser um vir-a-ser permanente, e isso inclui identidades, hábitos e sexualidades" (MORICONI, 2012, p. 230).

Chegou-se a conclusões próximas às de Carlos Nelson Ferreira dos Santos em sua "Filmografia do hábitat" (1982, p. 5), de que a quantidade de material audiovisual disponível é muito grande, mas "este acervo precioso sofre com a ociosidade, por falta de conhecimento e dificuldade de acesso". A filmografia de Brasília sofre do mesmo mal. Sem um arquivo ou cinemateca que reúna o conjunto da produção audiovisual realizada em Brasília, este acervo está em parte "escondido" com seus produtores, arquivado ainda sem a devida catalogação, aguardando verba para restauração ou está em formatos/suportes que não permitem fácil visualização.

Foi possível verificar a quantidade e a qualidade do que se produziu, a urgência em sua catalogação e arquivamento e, principalmente, a necessidade de difusão deste material que contém fatos importantes da história de Brasília e, por que não?, do Brasil. A melhor maneira de proteger este acervo é torná-lo conhecido. 


\section{CONSIDERAÇÕES FINAIS}

Esta pesquisa mostrou-se abrangente pela quantidade de material analisado, mas também pelo trajeto que se fez necessário percorrer: a cidade e o cinema no século XX como embasamento para que se pudesse colocar uma lupa sobre Brasília. Durante o percurso foi possível perceber a quantidade de recortes possíveis, as diversas maneiras de abordar ou agrupar determinados assuntos com o intuito de construir uma compreensão do que se pretendia observar: a experiência urbana em Brasília, a cidade modernista e planejada, que através de narrativas presentes em suas representações cinematográficas mostra como os habitantes experimentam, vivem, reconhecem e apropriam-se de seus espaços, de seus fluxos, constituindo a partir dessa experiência, um sentido de lugar.

Assim, o ponto de partida que se deu na cidade industrial, ambiente que inspirou as diversas utopias e teorias de renovação urbana, possibilitando novas experiências de espaço e tempo, entre elas o cinema e sua imagem-movimento. Seguem percursos paralelos, porém inseparáveis, a cidade e o cinema, a representar e inspirar-se mutuamente. A relação que se estabeleceu reside na maneira que o cinema retratou as cidades e seus fluxos e como foi influenciado por elas.

Tema central dos debates vanguardistas no final do século XIX e início do XX, o ambiente urbano fez emergir os conceitos aparentemente antagônicos de materializar ou representar um momento em que tudo é transitório e efêmero, constituindo uma resposta à experiência da modernidade e aos problemas e possibilidades resultantes do processo de modernização. As vanguardas forneceram narrativas urbanas ao tematizar, problematizar e criticar os padrões de comportamento estabelecidos pelo ambiente urbano ao homem metropolitano (e viceversa), realizando um movimento de resistência, de abertura do imaginário e de compartilhamento de subjetividades e experiências.

A imagem em movimento se fez instrumento de análise das cidades, enquanto espaço compartilhado e vivenciado, devido à maneira dinâmica em que captou e projetou a imagem das cidades durante todo o século XX. Mas na percepção de que há uma ligação profunda entre relação do corpo com o espaço na experiência das ruas e na experiência do cinema, legitima-se a análise do movimento e repouso na cidade, na qual o cinema pode contribuir significativamente. Para Walter Benjamin, o flanêur - o "caminhante ordinário" da segunda metade do século XIX - vivia a cidade como se estivesse fazendo um filme. Da mesma maneira, o espectador de 
um filme sente o tempo e o espaço da cidade tanto através da observação das imagens na tela como pela sua experiência interna.

O deslocamento das imagens, o desenvolvimento das cenas e ações, os cortes, os intervalos, as durações, as velocidades, enfim, tudo o que se passa na tela no tempo real de projeção é sempre o que se passa na tela mental do espectador - e que vai ressoar em seu corpo (OLIVIERI, 2011, p. 53).

Ao confrontar a cidade e o cinema, usado como representação dos espaços e da experiência da velocidade e do fluxo da cidade, pode-se dispor de outras ferramentas de análise do espaço, como indica SolàMorales (2002). Esse autor percebe falhas nas representações convencionais do espaço e argumenta que nada substitui a experiência do lugar do fluxo:

O uso da representação convencional, perspectiva, permanece completamente equivocado, ainda que se utilizem sofisticados programas de CAD. Inútil continuar mostrando visões, sejam animadas, em movimento, virtual, etc. A experiência do lugar do fluxo é cinestésica, distraída como dizia Walter Benjamin (...). Produzir formas da experiência do fluido e tê-los disponíveis para análise, experimentação e projeto é, hoje, ainda mais um desejo do que uma realidade acessível ${ }^{52}$. (SOLÀMORALES, 2002, p. 134)

Com o objetivo de observar essas narrativas urbanas em Brasília percorreu-se o mesmo paralelo cinema/cidade ao se debruçar no panorama nacional, para compreender as diversas experimentações artísticas ocorridas no Brasil, ressaltando dois períodos importantes na busca e na representação do desejo de modernidade. O período após 1920 e a vanguarda moderna na busca de uma identidade nacional, e o período após $195^{\circ}$ e as experiências concretas, que continham uma forte crítica ao desenvolvimento (ou subdesenvolvimento) das cidades brasileiras. Ao que o cinema não deixou de captar.

Ao lançar mão dos elementos simbólicos oferecidos pela arquitetura moderna e sua "brasilidade", a construção da nova capital, Brasília, em 1960, deu um novo impulso aos debates sobre a urbanização e modernização brasileira, envolvendo tanto o cinema quanto outras formas de expressão artística e os meios de comunicação.

$5^{2}$ Tradução livre: “El uso de la representación convencional, perspectiva, sigue siendo completamente equivocada aunque para ello se utilicen sofisticados programas de CAD. De nada sirve seguir mostrando visiones, aunque sean animadas, em movimento, virtuales, etc. La experiência del lugar del flujo es cinestesica, distraída como hubiera dicho Walter Benjamin (...). Producir formas de la experiência de lo fluido y poder disponer de ellas para el analisis, la experimentacion y el proyecto constituye, hoy por hoy, todavia más um deseo que uma realidade asequible". 
Brasília, a imagem mais forte da afirmação nacional moderna, ao assumir em seu traçado urbanístico os princípios funcionalistas corbuseanos, da Carta de Atenas, em particular a separação das funções no espaço da cidade e a construção de blocos hegemônicos de apartamentos para habitação massiva, assumiu também as críticas que se direcionavam ao modernismo, notadamente ao estilo internacional.

No entanto, Brasília incorporou também a "brasilidade" tanto almejada, e seu traçado original é hoje apropriado, configurado e reconfigurado pelos seus habitantes continuamente. Portanto não se pretendeu nesta pesquisa olhar Brasília pelo seu traçado, pelos seus mapas e fotos aéreas, mas sim, ao "rés-do-chão", pelas narrativas partilhadas por seus moradores, artistas, admiradores ou críticos. Por seus errantes.

As narrativas errantes foram escritas nos desvios da própria historia do urbanismo. Elas constituem outro tipo de historiografia, ou de escrita da história, uma história errante, não linear, que não respeita a cronologia tradicional, uma história do que está na margem, nas brechas, nos desvios e, sobretudo, do que é ambulante, não está fixo, mas sim em movimento constante.

Assim, a narrativa fundadora da cidade, a sua representação mitológica, hegemônica, moderna e legitimadora é bastante presente no primeiro material de memória de Brasília e vai aos poucos se repartindo em fragmentos menores. O movimento se acalma, a velocidade diminui e se percebem outras possibilidades narrativas como maneira de compartilhar experiências a partir do momento que a cidade começa a ser vivenciada. São narrativas menores, diante das grandes narrativas modernas: "elas enfatizam as questões da experiência, do corpo e da alteridade na cidade, e assim, reafirmam a enorme potência da vida coletiva, uma complexidade e multiplicidade de sentidos que confronta qualquer "pensamento único ou consensual" (JACQUES, 2012, p. 20).

A cidade que inicialmente era mostrada do alto, ou percorrida em velocidade, começa a mostrar a multiplicidade de lugares. Especialmente seus lugares amplos, e nem sempre vazios, que remetem ao Terrain Vague: "lugares aparentemente esquecidos onde parece predominar a memória do passado sobre o presente. São lugares obsoletos em que somente alguns valores residuais parecem manter-se apesar de sua completa desafeição da atividade da cidade." (SOLÀ-MORALES, 1995, p. 187)

Os monumentos, volumes construídos, formas fortes que representam o poder, os traçados geométricos das grandes infraestruturas já não interessam aos artistas, fotógrafos e cineastas? Os espaços sem limites precisos, os espaços obsoletos, os fundos, os espaços de fluxos parecem chamar mais atenção. 
Parece que todo o destino da arquitetura tem sido sempre o da colonização, pôr limites, ordem, forma, introduzindo no espaço estranho os elementos de identidade necessários para fazê-lo reconhecível, idêntico, universal. Pertence à essência da arquitetura sua condição de instrumento de organização, de racionalização, de eficácia produtiva capaz e de transformar o inculto em cultivado, o baldio em produtivo, o vazio em edificado. (SOLÀ-MORALES, 1995, p. 191) ${ }^{53}$

Em Brasília percebeu-se em suas experiências urbanas o quanto esses espaços "vazios", "vagos", "do vagar", da lentidão e da liberdade são fundamentais na construção de um sentido de lugar. Não somente o efêmero e o transitório que ganham importância na configuração de identidades, mas a partilha das experiências urbanas da alteridade, a atenção aos fluxos, energias e ritmos que o passar do tempo e a perda dos limites têm estabelecido, onde reside o potencial de desestabilizar as partilhas hegemônicas da cidade planejada, eficaz e legitimada.

Quando o movimento se acalma e acaba a ansiedade da construção da cidade como um todo, são as brechas, fissuras, os desvios, a ocupação dos pequenos espaços, os interstícios que foram aparecendo no grande concreto branco, entre os fluxos do movimento, mostrando a cidade por dentro, deixando brotar as pequenas histórias, que foram construindo em Brasília, o sentido de lugar.

${ }^{53}$ Tradução livre: "parece que todo el destino de la arquitectura ha sido siempre el de la colonización, el poner limites, orden, forma, introduciendo en el espacio extraño los elementos de identidad necesarios para hacerlos reconocible, idéntico, universal. Pertenece a la esencia misma de la arquitetura su condición de instrumento de organización, de racionalización, de eficacia productiva capaz y de transformar lo inculto en cultivado, lo baldío en productivo, lo vacío en edificado". 


\section{LISTA DE FIGURAS}

Figura 1: Still do filme "Brasília: planejamento urbano", de Fernando Cony Campos, 1964. Fonte: CTAv-MinC.

Figura 2: Still do filme "Os anos JK: uma trajetória política", de Silvio Tendler, 1980. Fonte: Caliban Filmes

Figura 3: Still do filme "Brasília segundo Feldman", de Vladimir Carvalho, 1979. Fonte: CPCEUnB.

Figura 4: Still do filme "Brasília: um roteiro de Alberto Cavalcanti", de 1982. Fonte: CTAvMinC.

Figura 5: Paul Citroen, "Metropolis" (Großstadt), 1923. Fonte: Solà-Morales,

"Representaciones: de la ciudad capital a la metropoli", 1994. .13

Figura 6: Sequência de movimento "Two males (nude) wrestling Graeco-Roman", 1872-1885, por Eadweard James Muybridge (1830 -1904). Fonte: http://www.racollection.org.uk, acesso em 03.02.2014.

Figura 7: "L'Enfant Carburateur", de Francis Picabia, dadaísmo,1919. Fonte:

http://www.guggenheim.org, acesso em 03.04.2014.

Figura 8: "La Clarinette", de Georges Braque, cubismo,1912. Fonte:

http://www.guggenheim.org, acesso em 03.04.2014.

Figura 9: "Roter Ballon", Paul Klee, expressionismo, 1922. Fonte:

http://www.guggenheim.org, acesso em 03.04.2014. 16

Figura 10: "La Naissance des désirs liquides", Salvador Dalí, surrealismo, 1932. Fonte:

http://www.guggenheim.org, acesso em 03.04.2014. .16

Figura 11: "Città Nuova”, Antonio Sant'Elia, 1912. Fonte: Frampton, 2008..................................18

Figura 12: "Monumento à Terceira Internacional", de Vladimir Tatlin, exposto em 1920, seria erguido no centro de Moscou. A foto é de sua maquete, exposta na Royal Academy of Arts de Londres, em 2011. Fonte: http://www.racollection.org.uk

Figura 13: Imagens do filme "Ballet Mécanique", de Fernand Léger, 1924. Fonte:

www.cinematheque.fr, acesso em 04.03.2013. 20

Figura 14: Claude Monet, "Les déchargeurs de charbon", cerca de 1875, Musée d'Orsay, Paris, France. www.musee-orsay.fr/fr/collections/catalogue-des-oeuvres, acesso em 16.06.2013 ....22 Figura 15: Plano da Cidade Linear, arredores de Madri (1894). Fonte:

http://web.tiscali.it/icaria/urbanistica/utopie/soria.htm, acesso em 14.06.2013. 24

Figura 16: Diagrama n.7 - conjunto de seis Cidades-Jardins menores e uma maior 24

Figura 17: Tony Garnier, "Citè Industrielle" (1901-1917), estação ferroviária. Fonte: franksvensson.blogspot.com.br, acesso em 14.06.2013. .25

Figura 18: Le Corbusier, "Ville de 3 millions d'habitants". Fonte:

http://laboratoireurbanismeinsurrectionnel.blogspot.com.br, acesso em 23.06.2013. 29 
Figura 19: "Ville Radieuse", Le Corbusier, 1930. A planta mostra o zoneamento das funções da cidade (educação, negócios, residências) em faixas paralelas. Fonte: FRAMPTON, 2008, p.

Figura 20: "Architecture”, László Moholy-Nagy. Foto:Jan Kamman/Schiedam. Fonte

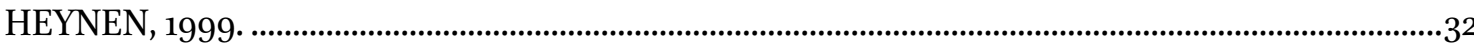

Figura 21: Praxinoscópio. Fonte: http://kinodinamico.com, acesso em 03.02.2014. ....................37

Figura 22: Ilustração apresenta a figura de Charles-Émile Reynaud (1844-1918) operando o dispositivo enquanto a multidão assiste à animação. Fonte: http://kinodinamico.com, acesso em 03.02.2014.

Figura 23: "Um homem com uma câmera de filmar" (Dziga Vertov, 1929). Fonte:

http://www.contracampo.com.br, acesso em 03.04.2014.

Figura 24: "Roma, cidade aberta", Roberto Rossellini, 1945. Fonte: still do filme,

http://worldscinema.org, acesso em 03.02.2014.

Figura 25: still do filme "Jules et Jim", Truffaut, 1962. Fonte: www.cinematheque.fr, acesso em 04.04.2014.

Figura 26: "São Paulo", Tarsila do Amaral, 1924. Fonte: SCHWARTZ, 2002, p. 67 ………………..53

Figura 27: "Sol poente", Tarsila do Amaral, 1929. Fonte: SCHWARTZ, 2002, p. 64...................... 54 Figura 28: Max Bill, 1967. Fonte: Enciclopédia de Artes Visuais Itaú Cultural, acesso em julho de 2013.

Figura 29: Waldemar Cordeiro, "Movimento", 1951. Fonte: Enciclopédia de Artes Visuais Itaú Cultural, acesso em julho de 2013. 57

Figura 30: "Caetano Veloso com Parangolé - Hélio Oiticica". Foto: Geraldo Viola. Fonte:

Marginália Arte \& Cultura "na idade da pedrada”, Marisa Alvarez Lima, 1996. 60

Figura 31: "Caetano Veloso com Parangolé, Hélio Oiticica”. Foto: Geraldo Viola. Fonte:

Marginália Arte \& Cultura "na idade da pedrada", Marisa Alvarez Lima, 1996. 60 Figura 32: Gregori Warchavchik, 1928, Casa na Rua Santa Cruz, São Paulo. Fonte: MARTINS, 2002.

Figura 33: Edifício MES, Rio de Janeiro, 1936-1945. Fonte: Foto de Eduardo Pinha, 2014. ........ 65 Figura 34: Fachadas de alguns cinematógrafos da Av. Central. No ${ }^{\circ}{ }_{134}$, funcionou o Cinema Kosmos, de 1910 a 1911; no no 116, o segundo Cinema Pathé, que funcionou até 1940; no ${ }^{\circ}{ }^{179}$, funcionou o Cinema Parisiense, onde hoje se encontra o Teatro Glauce Rocha; e, finalmente, nos $n^{\text {os }} 151$ e 153, o Cinema Avenida. (Álbum da Avenida Central, de Marc Ferrez. Reprodução de Roberto Jesus Oscar).

Figura 35: Fachada do Cinema Pathé Palácio, imagens encontradas em diversos sítios de imagens do Rio antigo, mas sem fonte atribuída.

Figura 36: Fachada do cinema Pathé Palácio, com os painéis, letreiros e cartazes de divulgação do filme "Os três mosqueteiros", Rio de Janeiro, 1933. Fonte: Arquivo Nacional RJ.

Figura 37: Cartaz de divulgação do filme "São Paulo, a symphonia da metrópole", 1929. Fonte: Cinemateca Brasileira - MinC.

Figura 38: Colégio Cataguases 1945-1949, projeto de Oscar Niemeyer, paisagismo de Burle Marx, painéis de Candido Portinari e Paulo Werneck e mobiliário de Joaquim Tenreiro. Fonte: Guia da Arquitetura Modernista de Cataguases, 2012. 
Figura 39: Cena do filme "Rio, Zona Norte", de Nelson Pereira dos Santos, 1957. Fonte: http://cineola.wordpress.com, acesso em 08.08.2013 .........................................................................73

Figura 40: Esboços do projeto de Lucio Costa. Fonte: CARPINTERO, 1998................................... 78

Figura 41. Memória descritiva do Plano Piloto de Brasília. Lucio Costa, 1957. Fonte: COSTA,

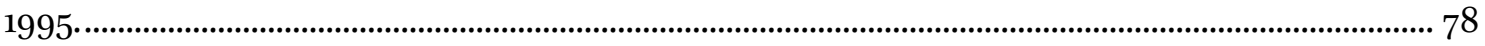

Figura 42: Plano Piloto de Brasília, Lucio Costa. Fonte: COSTA, 1995 …………………………...... 80

Figura 43 e Figura 44: vistas do eixo monumental. Fotos: Cleber Figueredo, 2006 .................... 81

Figura 45 e Figura 46: Stills do filme "Brasília, contradições de uma cidade nova", de Joaquim

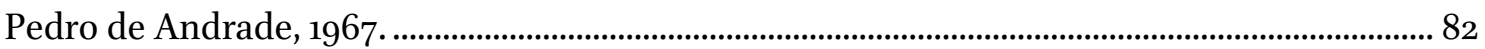

Figura 47 e Figura 48: Stills do filme "Braxília", de Danyella Proença, 2010...................................83

Figura 49: Rodoviária. Still de "Brasília: planejamento urbano", Fernando Cony Campos,

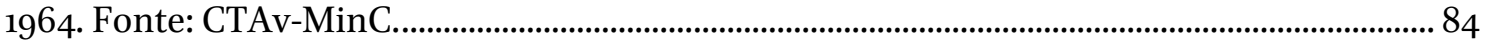

Figura 5o: Rodoviária. Still do filme "Braxília", de Danyella Proença, 2010.................................... 84

Figura 51 e Figura 52: via S2 e escadaria no Setor Comercial Sul. Stills do filme "Brasiliários",

de Zuleica Porto e Sérgio Bazi, 1986 ................................................................................................. 85

Figura 53: Rodoviária. Still do filme "Braxília", de Danyella Proença, 2010..................................... 86

Figura 54: Capas dos números da Revista Brasília (1) janeiro 1957, (2) fevereiro 1957 e (3)

março de 1957. Fonte: Arquivo Público do Distrito Federal - ArPDF.............................................. 88

Figura 55: Cartaz do filme "Os Bandeirantes". ................................................................................... 94

Figura 56: Stills do filme "Brasília, planejamento urbano", Fernando Cony Campos, 1964.

Fonte: CTAv-MinC............................................................................................................................ 95

Figura 57: Stills do filme "Brasília, contradições de uma cidade nova", de Joaquim Pedro de

Andrade, 1967. Fonte: Filmes do Serro.............................................................................................. 96

Figura 58: Stills do filme "Brasília, contradições de uma cidade nova", de Joaquim Pedro de

Andrade, 1967. Fonte: Filmes do Serro.............................................................................................. 97

Figura 59: Still do filme "Fala Brasília", de Nelson Pereira dos Santos, 1966. Fonte: CPCE-UnB.

Figura 6o: Cartazes dos filmes "Terra em transe", "Os herdeiros", e "O bravo guerreiro". Fonte: Cinemateca de São Paulo. 100

Figura 61: Stills do filme "Vestibular 70", Vladimir Carvalho, 1970. ..................................................101

Figura 62: Still do filme "Brasília, ano 10", de Geraldo Sobral Rocha, 1970....................................103

Figura 63: Still do filme "Mínima cidade", João Lanari, 1984. Fonte: acervo do diretor.............108 Figura 64: Still do filme "Brasiliários”, Sergio Bazi e Zuleica Porto (1986). Fonte: CPCE-UnB.

109

Figura 65: stills do filme "O sonho não acabou", de Sergio Rezende, 1982. Fonte: Embrafilme

.111

Figura 66: Stills de "Feliz aniversário, Urbana", de Betse de Paula, 1996.......................................115

Figura 67: Stills do filme "Brasília, um dia em fevereiro", Maria Augusta Ramos, 1996. Fonte:

acervo particular da diretora.........................................................................................................116

Figura 68: Stills do filme "Subterrâneos", José Eduardo Belmonte, 2003.......................................118

Figura 69: Stills do filme "A concepção", José Eduardo Belmonte, 2005. Fonte: acervo

particular do diretor.

Figura 70: Stills do filme “A cidade é uma só?", Adirley Queirós, 2011. Fonte: acervo particular do diretor. 


\section{REFERÊNCIAS BIBLIOGRÁFICAS}

ALONSO, P. H. Guia da Arquitetura Modernista de Cataguases. 2. ed. Cataguases: Instituto Cidade de Cataguases, 2012.

AMARAL, A. Artes Plásticas na Semana de 22. 5. ed. São Paulo: Editora 34, 1998.

AMARAL, T. D. Pintura Pau Brasil e Antropofagia (1939). In: SCHWARTZ, J. Da Antropogafia a Brasília: Brasil 1920-1950. São Paulo: FAAP - Fundação Armando Alvares Penteado e Cosac \& Naify Edições, 2002. p. 469-470.

ARCHANGELO, R. Um bandeirante nas telas de São Paulo. O discurso Adhemarista em Cinejornais (1947-1952). São Paulo: [s.n.], 2007.

BAHIA, B. Brasília 5.2: Cinema e memória, 196o - 2012. Brasília: [s.n.], 2012.

BASSANI, J. As linguagens artísticas e a cidade: cultura urbana do século XX. São Paulo: FormArte, 2003.

BAUMAN, Z. Modernidade líquida. Tradução de Plínio DENTZIEN. Rio de Janeiro: Jorge Zahar, 2001.

BAUMAN, Z.; PALLARES-BURKE, M. L. G. A Sociedade Líquida. Caderno Mais, São Paulo, 19 outubro 2003. Texto introdutório e entrevista especial para a Folha.

BENEVOLO, L. As origens da Urbanística Moderna. Tradução de Conceição Jardim e Eduardo Nogueira. 3. ed. Lisboa: Editorial Presença, 1994.

BENJAMIN, W. A obra de arte na era de sua reprodutibilidade técnica. In: BENJAMIN, W. Magia e técnica, arte e política: Ensaios sobre literatura e historia da cultura. Tradução de Sergio Paulo Rouanet. [S.l.]: editora brasiliense, v. 1, 1936.

BERMAN, M. Tudo que é sólido desmancha no ar: A aventura da modernidade. Tradução de Carlos Felipe Moises e Ana Maria L. Ooriatti. 10. ed. São Paulo: Companhia das Letras, 1986.

BICCA, P. Brasília - Mitos e Realidades. In: XAVIER, A.; KATINSKY, J. Brasília: Antologia Crítica. sao paulo: Cosac Naif, 1985. p. 208-218.

BOURDIEU, P. Razões práticas: Sobre a teoria da ação. Tradução de Mariza CORRÊA. Campinas: Papirus, 1996. 
BRITO, R. Neoconcretismo: vértice e ruptura do projeto construtivo brasileiro. Rio de Janeiro: FUNARTE / Instituto Nacional deArtes Plásticas, 1985.

BRUAND, Y. Arquitetura contemporânea no Brasil. Tradução de Ana M. GOLDBERGER. São Paulo: Perspectiva, 2008.

BUENO, E. Brasil: uma História. São Paulo: Editora Ática, 2003.

CALDAS, R. W.; MONTORO, T. A evolução do Cinema Brasileiro no Seculo XX. 1. ed. Brasília: Casa das Musas, 2006. 312 p.

CÁNEPA, L. L. Expressionismo alemão. In: MASCARELLO, F. História do cinema mundial. Campinas: Papirus, 2006. p. 55-88.

CAPPELLO, M. B. C. A revista brasília na construção da Nova Capital: Brasília (1957-1962). Revista Risco, São Carlos, v. 11, p. 43-58, jan. 2010.

CARPINTERO, A. C. C. Brasília: prática e teoria urbanística no Brasil, 1956 -1998. São Paulo: Tese de doutorado, FAU-USP, 1998.

CARVALHO, M. D. S. Cinema Novo brasileiro. In: MASCARELLO, F. História do cinema mundial. Campinas: Papirus, 2006. p. 289-309.

CARVALHO, V. Cinema Candango: Matéria de Jornal. Brasília: Cinememória, 2002.

CASTELLS, M. O poder da Identidade. 2. ed. São Paulo: Paz e Terra, v. 2, 2008.

CHARNEY, L.; R.SCHWARTZ, V. introdução. In: CHARNEY, L.; R.SCHWARTZ, V. O cinema e a invenção da vida moderna. Tradução de Regina Thompson. 2. ed. São Paulo: Cosac Naif, 2004.

CHOAY, F. O Urbanismo. Tradução de Dafne Rodrigues. São Paulo: Perspectiva, 2007.

CORBUSIER, L. Por uma arquitetura. 2. ed. Sao Paulo: Perspectiva, 1977.

COSTA, F. C. Primeiro Cinema. In: MASCARELLO, F. História do cinema mundial. Campinas: Papirus, 2006. Cap. 1, p. 17-54.

COSTA, L. Considerações sobre arte contemporânea (1940). In: COSTA, L. Lúcio Costa: registro de uma vivência. São Paulo: Empresa das Artes, 1995. p. 608.

COSTA, L. Memória Descritiva do Plano Piloto (1957). In: COSTA, L. Lúcio Costa: registro de uma vivência. São Paulo: Empresa das Artes, 1995• p. 283-297. 
COSTA, R. D. G.-R. Salas de cinema Art Déco no Rio de Janeiro: A conquista de uma identidade arquitetonica (1928-1941). História, Ciência e saúde - manguinhos, Rio de Janeiro, v. 5, fevereiro 1999. ISSN 3.

CURTIS, W. J. R. Arquitetura Moderna desde 19oo. Tradução de Alexandre Salvaterra. 3. ed. [S.l.]: bookman, 2008.

DAHER, L. C. Flávio de Carvalho: arquitetura e expressionismo. São Paulo: Projeto Editores, 1982.

DE CERTEAU, M. A invenção do Cotidiano: 1. Artes de fazer. Tradução de Ephraim F. ALVES. Petrópolis: Vozes, 2011.

DELEUZE, G. Cinema 1- A imagem-movimento. Tradução de Stella Senra. [S.l.]: Editora Brasiliense S.A., 1983.

DELEUZE, G. Bergsonismo. Tradução de Luiz B. L. Orlandi. 2. ed. São Paulo: Editora 34, 2012.

DOS SANTOS, C. N. F. Filmografia do Habitat. Instituto Brasileiro de Administração Municipal. Brasília. 1982.

FABRIS, M. Neo-realismo italiano. In: MASCARELLO, F. História do cinema mundial. Campinas: Papirus, 2006. p. 191-220.

FABRIS, M. Neo-realismo italiano. In: MASCARELLO, F. História do cinema mundial. Campinas: Papirus, 2006. p. 191-220.

FABRIS, M. Um "mundo novo": o cinema segundo os futuristas e os modernistas. Artelogie, setembro 2011. Acesso em: 03 julho 2013.

FERRO, M. O filme, uma contra-análise da sociedade? In: NORA, P. História: novos objetos. Rio de Janeiro: Francisco Alves, 1975.

FICHER, S. Antonio Garcia Moya, um arquiteto da Semana de 22. mdc revista de arquitetura e urbanismo, 1998. Disponivel em: $<$ http://mdc.arq.br/2012/03/20/antonio-garcia-moya-umarquiteto-da-semana-de-22/>. Acesso em: fevereiro 2014.

FICHER, S.; LEITAO, F. A Infancia do Plano Piloto: Brasília 1957-1964. In: PAVIANI, A. (. ). Brasília 50 anos: da capital a metropole. Brasília: UnB, 2010. p. 97-135.

FRAMPTON, K. História Crítica da Arquitetura Moderna. Tradução de Jefferson Luiz Camargo. 2. ed. Sao Paulo: Martins Fontes, 2008.

GERVAISEAU, H. Dziga Vertov: Do cinema verdade à arte da passagem entre as imagens. Cinemais, p. 57-68, setembro-outubro 1996. 
GHIRARDO, D. Arquiettura contemporânea: uma história concisa. Tradução de Maria Beatriz de Medina. São Paulo: Martins Fontes, 2002.

GLAUBER por Glauber, mostra da obra completa de Glauber Rocha, como ele a desejou : filmes, exposição, livro, vídeo. [S.l.]: Empresa Brasileira de Filmes, 1985.

GOMES, P. E. S. Cinema: trajetória no subdesenvolvimento. In: SCHWARTZ, J. Da antropofagia a Brasilia: Brasil 1920-1950. São Paulo: FAAP-Fundação Armando Alvares Penteado e Cosac \& Naify Edições, 2002. p. 486-491.

GONDIM, M. F. A travessia no tempo: homens e veículos, da mitologia aos tempos modernos. Brasília: tese de doutoramento, Universidade de Brasília, 2014.

GORELIK, A. Das vanguardas a Brasília: cultura urbana e arquitetura na América Latina. Tradução de Maria Antonieta Pereira. 1. ed. Belo Horizonte: Editora UFMG, 2005.

GULLAR, F. Vanguarda e Subdesenvolvimento: ensaios sobre arte. 3. ed. Rio de Janeiro: Civilização Brasileira, 1984 .

GUNNING, T. O retrato do corpo humano: a fotogafia, os detetives e os primórdios do cinema. In: CHARNEY, L.; R.SCHWARTZ, V. O cinema e a invenção da vida moderna. Tradução de Regina Thompson. 2. ed. Sao Paulo: Cosac Naify, 2004.

HARVEY, D. Condição pós-Moderna: uma pesquisa sobre as origens da mudança cultural. Tradução de Adail Ubirajara Sobral e Maria Stela Gonçalves. 21. ed. São Paulo: Edições Loyola, 2011.

HEYNEN, H. Architecture and Modernity, a critique. Cambridge: [s.n.], 1999.

JACQUES, P. B. Breve histórico da Internacional Situacionista - IS. Arquitextos, São Paulo, n. 035.05, abril 2003. Disponivel em:

<http://www.vitruvius.com.br/revistas/read/arquitextos/03.035/696>. Acesso em: junho 2014 .

JACQUES, P. B. Elogio aos Errantes. Salvador: EDUFBA, 2012. 331 p.

LE CORBUSIER. A Carta de Atenas (1941). Tradução de Rebeca Scherer. São Paulo: HUCITEC:EDUSP, 1993.

LECHTE, J. Cinquenta pensadores contemporâneos essenciais: do estruturalismo à pósmodernidade. Tradução de Fábio Fernandes. 6. ed. Rio de Janeiro: DIFEL, 2011. 280 p.

LIMA, M. A. Marginália Arte \& Cultura "na idade da pedrada". Rio de Janeiro: Salamandra, 1996. 
MANEVY, A. Nouvelle vague. In: MASCARELLO, F. História do cinema mundial. Campinas: Papirus, 2006. p. 221-252.

MARQUES, S. M. A revisão do movimento moderno? Arquitetura no Rio Grande do Sul dos anos 8o. Porto Alegre: Editora Ritter dos Reis, 2002.

MARTINS, C. A. F. Construir uma arquitetura, construir um país. In: SCHWARTZ, J. Da Antropofagia a Brasília: Brasil 1920-1950. São Paulo: FAAP - Fundação Armando Alvares Penteado e Cosac \& Naify, 2002. p. 373-383.

MEDEIROS, A. E.; CAMPOS, N. L. D. O. Cidade projetada, construída , tombada e vivenciada: pensando o planejamento urbano em Brasília. In: PAVIANI, A. Brasília 50 anos: da capital a metropole. Brasilia: UnB, 2010.

MINDLIN, H. E. Arquitetura moderna no Brasil. Rio de Janeiro: Aeroplano, 1999.

MONTORO, T. Imagens e Imaginários de Brasília. In: CASTRO, G. D. Mídia e Imaginário. 1. ed. Brasília: Annablume, 2012. Cap. 12, p. 212.

MORICONI, S. Apontamentos para uma história. Brasília: Instituto Terceiro Setor, 2012.

MÚRIAS, M. M. História breve do cinema. Lisboa: Editorial Verbo, 1962.

OLIVIERI, S. Quando o cinema vira urbanismo: o documentário como ferramenta de abordagem da cidade. Salvador: EDUFBA, PPGFAU, 2011.

PAVIANI, A. A construção injusta do espaço urbano. In: PAVIANI, A. A Conquista da Cidade: Movimentos Populares em Brasília. 2. ed. Brasília: Universidade de Brasília, 1998.

PEDROSA, M. Espaço e Arquitetura, 1952. In: AMARAL, A. Mario Pedrosa: dos murais de Portinari aos espaços de Brasília. São Paulo: Perspectiva, 1981. p. 251-255.

PIERRE, S. Glauber Rocha: textos e entrevistas com Glauber Rocha. Tradução de Eleonora Boottmann. Campinas: Papirus, 1996.

RIBONDI, A.; PEREIRA, C.; SCHETTINO, R. O sonho candango: memória afetiva dos anos 80. Brasília: Gabinete C, 2012.

RICOEUR, P. Architecture e Narrativité. Revue Urbanisme, p. 44-51, 1998. ISSN 303.

RICOEUR, P. Percurso do reconhecimento. São Paulo: Edições Loyola, 2006.

RISÉRIO, A. A Cidade no Brasil. 1. ed. São Paulo: Editora 34, 2012. 
ROLIM, A. L.; TRINDADE, I. L. Arquitetura Moderna no Cinema Pós-Guerra. 5 o Seminário DOCOMOMO Brasil. São Carlos: [s.n.]. 27 a 30 Outubro 2003.

SÁ, R. T. M. Cineastas de Brasília. Brasília: [s.n.], 2003.

SABOIA, L. O vazio moderno e o reconhecimento de paisagens culturais: $\mathrm{O}$ caso da rodoviária em Brasília, 2010.

SANDOVAL, L.; SABOIA, L. "A cidade é uma só?" Luta por reconhecimento na relação centro-periferia em Brasília. III Seminário Internacional Urbicentros. Salvador BA: UFBA. 2012.

SARAIVA, L. Montagem soviética. In: MASCARELLO, F. História do cinema mundial. Campinas: Papirus, 2006. p. 109-142.

SCHEFER, J.-L. L'homme ordinaire du cinema. Paris: Gallimard, 1980.

SCHWARTZ, J. Da antropofagia a Brasília: Brasil 1920-1950. São Paulo: FAAP- Fundação Armando Alvares Penteado e Cosac \& Naify Edições, 2002. 41-51 p.

SEGAWA, H. Arquiteturas no Brasil 19oo-199o. 3. ed. São Paulo: Editora da Universidade de São Paulo, 2010.

SIMMEL, G. A metrópole e a vida mental (1902). In: VELHO, O. G. O fenômeno urbano. Tradução de Sergio Marques do Reis. 4. ed. Rio de Janeiro: Zahar, 1979. p. 11-25.

SOLÀ-MORALES, I. D. Representaciones: de la ciudad capital a la metropoli. In: SOLÀMORALES, I. D. Territorios. [S.l.]: Gustavo Gili, 1994. p. 55-74.

SOLÀ-MORALES, I. D. Terrain Vague. In: SOLÀ-MORALES, I. D. Territorios. [S.l.]: Editorial Gustavo Gili, 1995. p. 181-194.

SOLÀ-MORALES, I. D. Arquitectura Líquida. In: SOLÀ-MORALES, I. D. Territorios. Barcelona: Gustavo Gili, 2002. p. 125-134.

SOLÀ-MORALES, I. D. Lugar: permanencia o producción. In: SOLÀ-MORALES, I. D.

Diferencias: topografía de la arquitectura contemporánea. Barelona: Gustavo Gili S.A, 2003. p. 101-115.

TARKOVSKI, A. Esculpir o tempo. Tradução de Jefferson Luiz Camargo. são paulo: Martins Fontes, 1990.

TEIXEIRA, F. E. Documentário moderno. In: MASCARELLO, F. História do cinema mundial. Campinas: Papirus, 2006. p. 253-288. 
TREVISAN, R. Incorporação do ideário da Garden-City inglesa na urbanística moderna brasileira: Águas de São Pedro. São Carlos: dissertação de mestrado UFSCar, 2003.

VIDAL, L. De Nova Lisboa a Brasília: a invenção de uma capital (séculos XIX-XX). Tradução de Florence Marie Dravet. Brasília: Editora Universidade de Brasília, 2009.

WARCHAVCHIK, G. Acerca da Arquitetura Moderna (1925). In: SCHWARTZ, J. Da Antropofagia a Brasília: Brasil 1920-1950. São Paulo: FAAP - Fundação Armando Alvares Penteado e Cosac \& Naify Edições, 2002. p. 506-507.

XAVIER, I. Sétima Arte: Um Culto Moderno. São Paulo: Perspectiva: Secretaria da Cultura, Ciência e Tecnologia do Estado de São Paulo, 1978.

XAVIER, I. A experiência do cinema: antologia. Rio de Janeiro: Edições Graal: Embrafilmes, 1983.

XAVIER, I. Sertão Mar: Glauber Rocha e a Estética da Fome. São Paulo: editora brasiliense: Embrafilme/ Secretaria da Cultura / MEC, 1983. 
ANEXOS 



\section{Filmes pesquisados}

Os 37 filmes selecionados para a pesquisa foram organizados em fichas catalográficas, que reúnem as principais informações sobre cada filme: título, ano de produção, equipe técnica, sinopse, duração e algumas informações adicionais ou curiosidades a respeito do filme. Organizadas em ordem cronológica, as fichas facilitaram o manuseio do material pela sistematização das informações.

$1 \quad$ As primeiras imagens de Brasília, 1957

2 Brasília: planejamento urbano, 1964

3 Universidade de Brasília: primeira experiência em pré-moldado, 1970

4 Fala Brasília, 1966

5 Brasília, contradições de uma cidade nova, 1967

6 Vestibular 70, 1970

7 Brasília, ano 10, 1970

8 Brasília segundo Feldman, 1979

9 Os anos JK: uma trajetória política, 1980

10 A idade da terra, 1980

11 O sonho não acabou, 1982

12 Brasília: um roteiro de Alberto Cavalcanti, 1982

13 Mínima cidade, 1984

14 Brasília, uma sinfonia, 1985

15 Brasíliários, 1986

16 Brasília, a última utopia, 1989

17 Conterrâneos velhos de guerra, 1990

18 Brasília, ano 35, 1995

19 Brasília, um dia em fevereiro, 1996

20 Feliz aniversário Urbana, 1996

21 Dois Candangos: a história passou por aqui, 1997

22 Barra 68: sem perder a ternura, 2000

23 Subterrâneos, 2004

24 A concepção, 2005

25 Oficina Perdiz, 2005

26 Kiss Kiss Kissinger, 2007

27 Romance do vaqueiro voador, 2008

28 Memórias finais da República de Fardas, 2008

29 A saga das candangas invisíveis, 2008

30 Dias de greve, 2009

31 Insolação, 2009

32 Braxília, 2010

33 A arte de andar pelas ruas de Brasília, 2010

34 Sob o signo da poesia, 2011

35 Rock Brasília, 2011

36 Cru, 2011

37 A cidade é uma só?, 2012 



\section{As primeiras imagens de Brasília \\ Brasil. Documentário, preto e branco, 10 minutos}

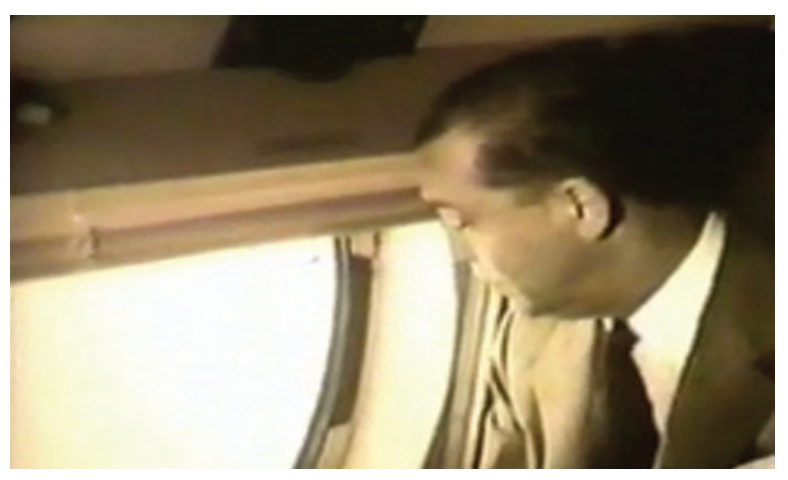

Equipe

DIRETOR Jean Manzon

PRODUtor/REAlizador Atlântida Empresa Cinematográfica do Brasil S.A

NARRAÇÃo Luiz Jatobá

MONTAGEM Italo di Bello

\section{Sinopse}

\section{Disponível em}

Digitalizado e disponibilizado no site www.acervojeanmanzon.com.br ArPDF: possibilidade de copia em dvd.

\section{Informações adicionais}

O vídeo, produzido pela Atlântida e dirigido pelo fotógrafo e documentarista francês Jean Manzon, mostra o nascimento de uma cidade "fadada a ser modelo para o mundo" e saudada como "noiva do Brasil", "a primeira metrópole construída na era da aviação", "menina dos olhos" do país. Encomendado por JK como resposta aos críticos da construção da nova capital, o documentário é narrado por Luiz Jatobá, locutor do Canal 100 e da Voz do Brasil, e manda recado aos mais céticos: "para os homens do litoral, Brasília é uma idéia mais ou menos abstrata. Para eles, os pioneiros, também conhecidos como candangos, é a pura realidade", diz. A nova capital é apresentada como uma "resposta à crítica de dois séculos" de um Brasil ainda voltado para o litoral e de costas para o seu interior. "Brasília já existe. As famílias que pra lá se deslocaram irão constituir amanhã a legião comovidamente lembrada dos pioneiros, primeiros homens e mulheres que deram ao Brasil os primeiros filhos de uma nova era." Mas a mensagem aos críticos é acompanhada de um convite a "uma épica aventura". "A cidade nova estende seus braços às irmãs mais velhas", narra Jatobá.

Referência acessada em junho de 2012: http://congressoemfoco.uol.com.br/noticias/ manchetes-anteriores/brasilia-50-anos-as-primeiras-imagens-da-capital/http://cinemateca. gov.br/cgi-bin/wxis.exe/iah/?IsisScript=iah/iah.xis\&base=FILMOGRAFIA\&lang=P\&nextAct ion=search\&exprSearch=ID=015469\&format=detailed.pft 


\section{Brasília: planejamento urbano \\ Brasil. Documentário, preto e branco, 10 minutos}

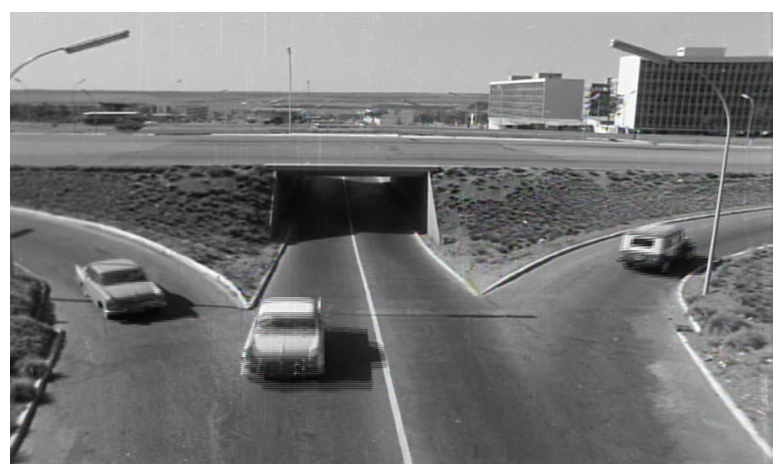

Equipe

DIRETOR Fernando Cony Campos

PRODUTOR/REALIZADOR INCE - Instituto Nacional de Cinema Educativo

ARgumento/Roteiro Maria Elisa Costa, Fernando Cony Campos

FOTOGRAFIA Leonardo Bartucci

\section{Sinopse}

A planificação da cidade, ligando sua arquitetura à sua topografia e as razões que lhe permitem possuir um tráfego normal e contínuo, suprimindo os problemas de circulação de todas as grandes cidades. Detalhes das construções destinadas ao Governo, às residências e ao comércio.

\section{Disponível em}

http://www.bcc.org.br/filme/detalhe/019276

Coletânea "urbanismo", CTAv-MinC

\section{Informações adicionais}

A locução do filme é baseada no Relatório do plano piloto de Lúcio Costa , de 1957. 


\section{2/1970 Universidade de Brasília: primeira experiência em pré-moldado}

Brasil. Documentário, preto e branco, 19 minutos

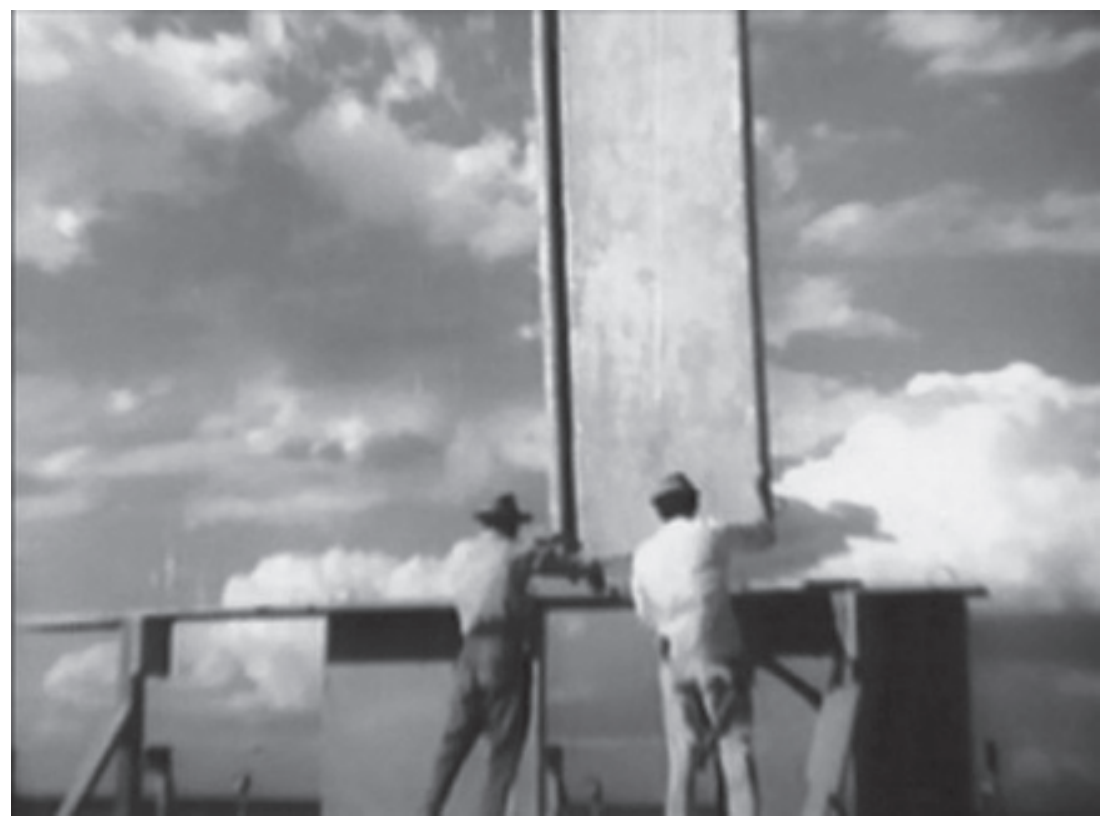

Equipe

DIRETOR Heinz Forthmann

PRODUTOR/REALIZADOR Heinz Forthmann / Universidade de Brasília ASSESSOR TÉCNICO João Filgueiras Lima

ASSESSORIA E TEXTO Luiz Fisberg

NARRAÇÃo José Carlos Coutinho

\section{Sinopse}

Documentário de 1970, mostra a construção dos blocos de Serviços Gerais da Universidade de Brasília, projetados por Oscar Niemeyer. Dirigido por Heinz Forthmann, com narração de José Carlos Coutinho, professor emérito da Faculdade de Arquitetura da UnB.

\section{Disponível em}

CPCE /UnB: a cópia é uma digitalização de uma matriz telecinada, em baixa qualidade. 


\section{Fala Brasília}

\section{Brasil. Documentário, preto e branco, 13 minutos}

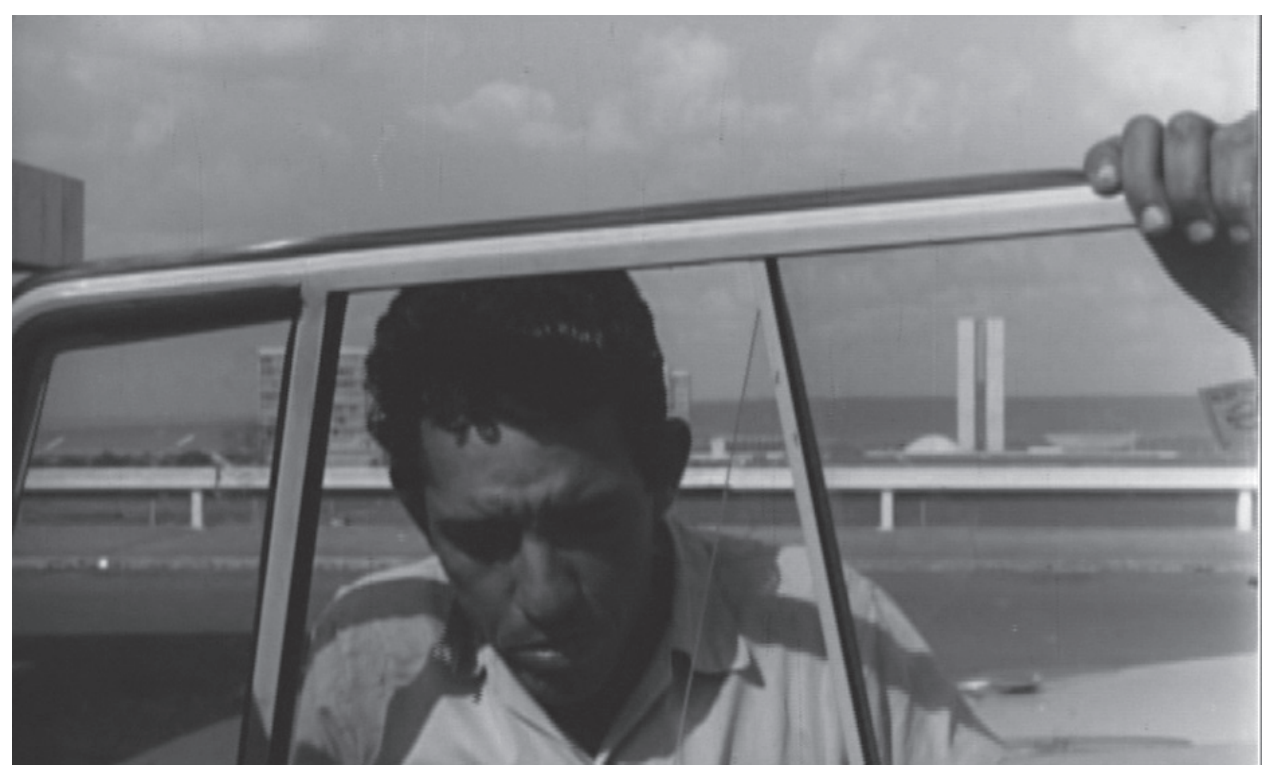

\section{Equipe}

DIRETOR Nelson Pereira dos Santos

PRODUTOR/REALIZADOR INCE - Instituto Nacional de Cinema Educativo

FOTOGRAFIA Dib Lutfi

MONTAGEM Nelson Pereira dos Santos, Alberto Salvá

\section{Sinopse}

Os diferentes acentos de alguns habitantes da cidade de Brasília. Cinco dos entrevistados, um de cada região geográfica brasileira, falam de sua participação no filme, pronunciam uma mesma série de palavras e nomeiam uma mesma série de objetos e fenômenos.

\section{Disponível em}

CPCE /UnB: a cópia é uma digitalização de uma matriz telecinada, em baixa qualidade. A versão restaurada faz parte da coletânea "urbanismo" lançada pelo Centro Técnico Audiovisual do Ministério da Cultura - CTAv-Minc. Fazem parte da mesma coletânea "Brasília, planejamento urbano" e "Brasília, um roteiro de Alberto Cavalcanti".

\section{Informações adicionais}

Durante o período em que ministrava aulas na UnB, o diretor realizou este curta documentário. Analisando o contexto do início de Brasilia, capital do desenvolvimento e do progresso, o filme busca nas vozes das pessoas que para cá vieram, depoimentos sobre as impressões pessoais da cidade.

Referência acessada em junho de 2012: http://www.cinemateca.gov.br/cgi-bin/wxis.exe/ $\operatorname{iah} / \#$

A coleção da qual este filme faz parte é composta por 110 curtas e médias metragens produzidos entre os anos de 1937 e 1983 pelo Instituto Nacional de Cinema Educativo - INCE e Instituto Nacional de Cinema - INC, completados por títulos da Empresa Brasileira de Filmes - Embrafilme e Departamento de Assuntos Culturais - Ministério da Educação e Cultura - DAC/MEC. 


\section{Brasília, contradições de uma cidade nova Brasil. Documentário, colorido, 23 minutos}

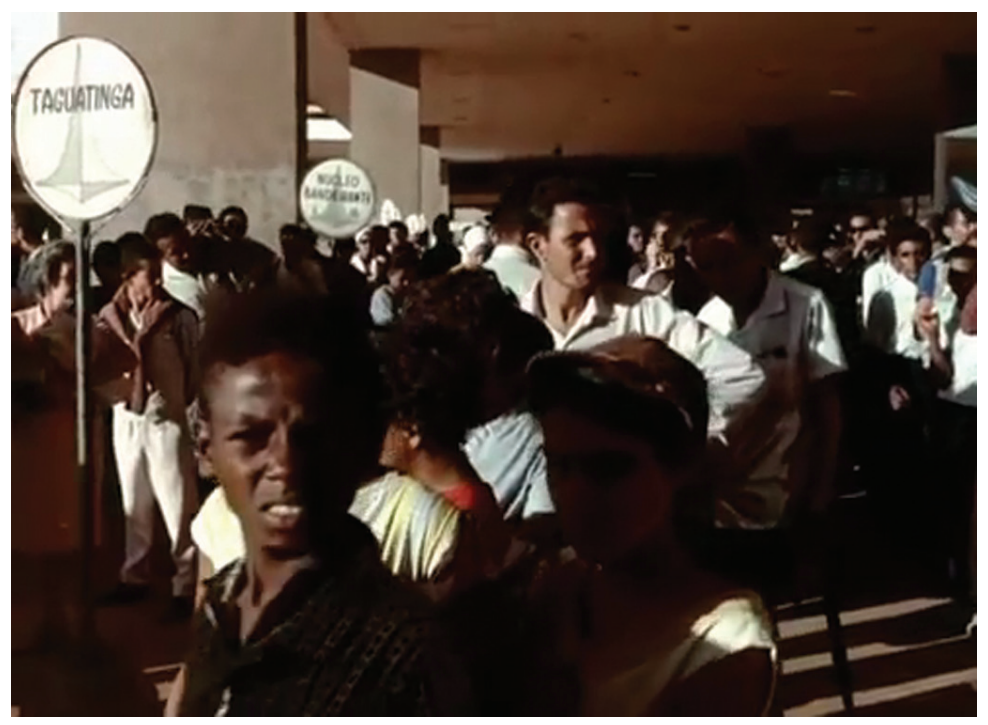

\section{Equipe}

Diretor Joaquim Pedro de Andrade

PRODUTOR/REALIZADOR Filmes do Serro - Rio de Janeiro

roteiro Joaquim Pedro de Andrade, Luís Saia e Jean-Claude Bernardet

MONTAGEM Bárbara Riedel

NARRAÇÃo Ferreira Goulart

\section{Sinopse}

Imagens de Brasília em seu sexto ano e entrevistas com diferentes categorias de habitantes da capital. Uma pergunta estrutura o documentário: uma cidade inteiramente planejada, criada em nome do desenvolvimento nacional e da democratização da sociedade, poderia reproduzir as desigualdades e a opressão existentes em outras regiões do país?

\section{Disponível em}

Filmes do Serro Ltda: TEL (21) 2532 2114, TEL/FAX (21) 25322128

E-MAIL contato@filmesdoserro.com.br

O filme faz parte do DVD Macunaíma, disponivel para locação.

\section{Informações adicionais}

Filmado em 1967 a pedido da empresa Olivetti, que queria um registro poético da nova capital. E foi isso que o diretor de Macunaíma fez, mas só na primeira metade do filme, o que fez a Olivetti rejeitar o curta e engavetá-lo por décadas. O descontentamento da empresa veio com a "liberdade poética" do diretor na segunda parte do filme. Depois de documentar a beleza das superquadras e dos palácios de Niemeyer, ao som de Erik Satie e narração de Ferreira Gullar, Joaquim faz um corte abrupto. E a câmera passa a focar nos imigrantes e operários, nos assentamentos precários e na falta de perspectiva dos estudantes, em uma UnB sufocada pela repressão.

Referência acessada em junho de 2013: http://www.filmesdoserro.com.br/film_br.asp CANÇÃo Viramundo, de Gilberto Gil e Capinam, interpretada por Maria Bethânia 


\section{Vestibular 70}

Brasil. Documentário, preto e branco, 15 minutos

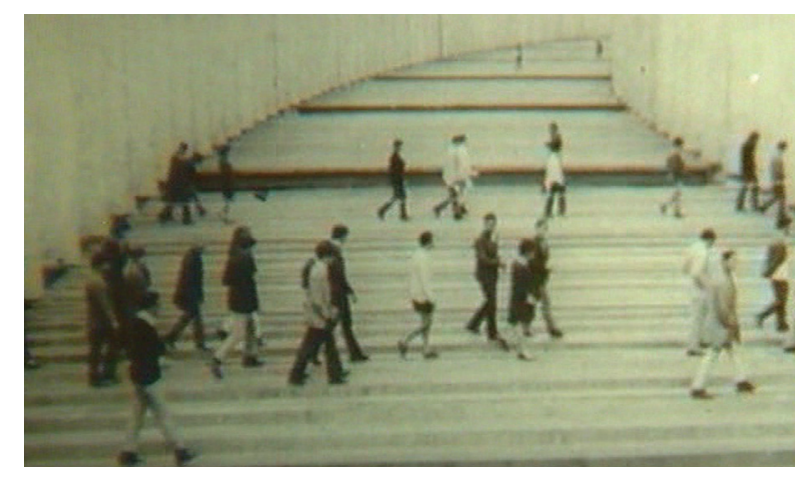

\section{Equipe}

DIRETOR Vladimir Carvalho, Fernando Duarte PRODUTOR/REALIZADOR Universidade de Brasília fotografia Fernando Duarte, Heinz Forthmann, Miguel Freire MONTAgEm Eduardo Leone, Cecil Thiré

\section{Sinopse}

Neste filme, realizado pelo Curso de Cinema do Instituto de Artes e Arquitetura, durante os exames vestibulares para 1970, concentram-se em Brasília estudantes de vários pontos do país; 5.500 candidatos ocupam o espaço do Instituto Central de Ciências - projetado por Oscar Niemeyer - que abrigará dez mil alunos em cursos regulares.

\section{Disponível em}

CPCE /UnB: a cópia é uma digitalização de uma matriz telecinada, em baixa qualidade.

\section{Informações adicionais}

Letreiro final do filme: "E a grande comoção multiplicada de ser, entre inumeráveis companheiros, um homem pequenino, desdenhável, resto de divisão e não obstante útil pedra na catedral dos homens". Do poeta maranhense Bandeira Tribuzi

Filme realizado pelo Curso de Cinema do Instituto de Artes e Arquitetura, UnB.

Referência acessada em junho de 2013: http://www.cinemateca.gov.br/cgi-bin/wxis. exe/iah/?IsisScript=iah/iah.xis\&base=FILMOGRAFIA\&exprSearch=vestibular and 7o\&nextAction $=$ lnk\&lang $=\mathrm{p} \#$ 


\section{Brasília, ano 10}

\section{Brasil. Documentário, colorido, 10 minutos}

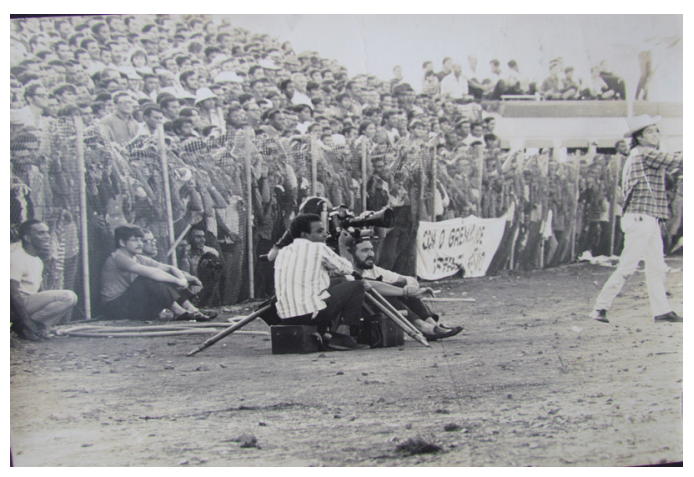

\section{Equipe}

DIRETOR Geraldo Sobral Rocha

COMPANHIA PRODUTORA Departamento de Turismo de Brasília

PRODUÇÃo Geraldo Sobral Rocha

CONTINUIDADE Alberto Cavalcanti

DiREÇÃo DE Fotografia Fernando Duarte, Heinz Forthmann

\section{Sinopse}

Uma reflexão sobre a cidade a partir de algumas ações comemorativas do seu 10 aniversário

\section{Disponível em}

Com o realizador

\section{Informações adicionais}

Trecho de narração do filme a partir de Henri Lefebvre, Lúcio Costa e Pero Vaz de Caminha: "Cidade é a projeção da sociedade sobre um local. Cidade é o conjunto das diferenças entre as cidades. Foram-se lá todos e andaram entre eles. E, segundo eles diziam, foram bem uma légua e meia a uma povoação e casas, as quais diziam que eram tão compridas cada, como esta nau capitânea, e eram de madeiras, e das ilhargas de tábuas e cobertas de palhas, de razoada altura, e todos em uma só casa, sem nenum repartimento. Se se desejar uma representação da cidade ideal e das suas relações com o universo, não é entre os filósofos que se deve procurar essa imagem, e sim entre os autores de ficção científica. Quanto ao problema residencial ocorreu a solução de criar-se uma sequência contínua de grandes quadras dispostas de ambos os lados da faixa rodoviária e emolduradas por uma larga cinta, densamente arborizada, prevalecendo em cada quadra determinada espécie vegetal, com chão gramado, e uma cortina suplementar intermitente de arbustos e folhagens, a fim de resguardar melhor, qualquer que seja a posição do observador, o conteúdo das quadras, visto sempre num plano e como que amortecido na paisagem. A realização da sociedade urbana exige uma planificação orientada para as necessidades sociais, as necessidades da sociedade urbana. Ela necessita de uma ciência da cidade. Por a arte ao serviço do urbano não significa enfeitar o espaço urbano com objetos de arte. Isso quer dizer que os temposespaços tornam-se obras de arte e que a arte passada é reconhecida como fonte e modelo de apropriação do tempo e do espaço".

Referência acessada em junho de 2013: http://cinemateca.gov.br/cgi-bin/wxis.exe/ $\mathrm{iah} /$ ?IsisScript $=\mathrm{iah} / \mathrm{iah} . x \mathrm{xis} \&$ base=FILMOGRAFIA\&lang=P\&nextAction=search\&exprSearch $=\mathrm{ID}=025777 \&$ format=detailed.pft 


\section{Brasília segundo Feldman \\ Brasil. Documentário, colorido, 20 minutos}

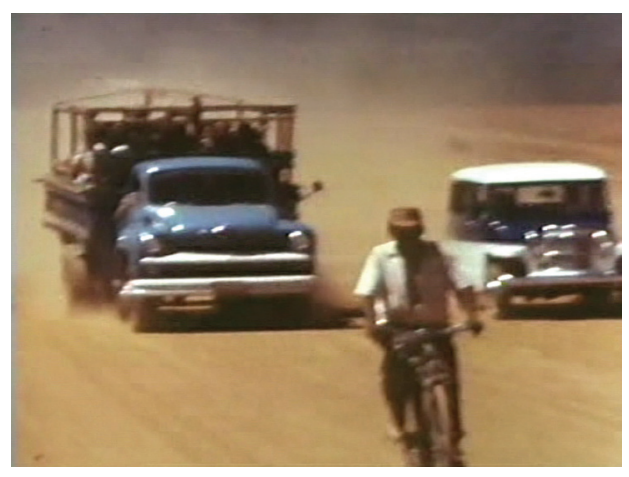

\section{Equipe}

DIRETOR Eugene Feldman, Vladimir Carvalho COMPANHIA PRODUTORA CNRC - Centro Nacional de Referência Cultural FOTOGRAFIA, CÂMERA Eugene Feldman

IMAGENS ADICIONAIS Alberto Cavalcanti e Walter Carvalho montagem Manfredo Caldas

\section{Sinopse}

Material documental filmado pelo 'designer' americano Eugene Feldman, em visita à Brasília na época de sua construção: a precariedade da segurança dos trabalhadores em razão do ritmo acelerado das obras e depoimentos de pioneiros sobre as condições de vida dos candangos.

\section{Disponível em \\ CPCE/UnB}

\section{Informações adicionais}

Letreiro do filme: Entrevista com os pioneiros Athos Bulcão, pintor, autor de vários painéis em Brasília e Luiz Perseghini, trabalhador na construção, hoje agricultor perto da capital.

Trata dos primeiros tempos de Brasília, mais exatamente do último ano de sua construção (l959). O filme enfoca polêmico acontecimento que foi o massacre de operários num acampamento de obra que funcionava onde hoje é a Vila Planalto, por motivos ainda não esclarecidos e que tem permanecido como uma terrível sombra na história da cidade.

Referência acessada em junho de 2014: http://cpdoc.fgv.br/brasilia/filmografia 


\section{$1980 \quad$ Os Anos JK, uma trajetória política}

Brasil. Documentário, preto e branco, 110 minutos

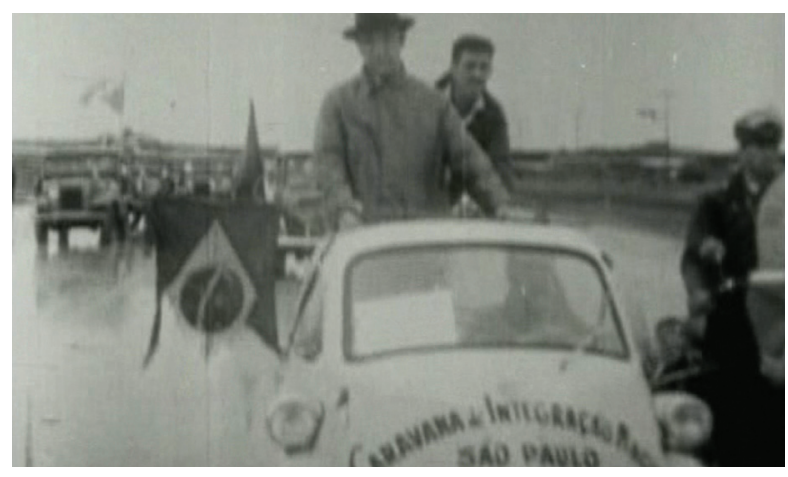

\section{Equipe}

DIRETOR Silvio Tendler

roteiro Silvio Tendler, Antonio Paulo Ferraz

PRODUÇÃo Silvio Tendler

FOTOGRAFIA Lucio Kodato

MONTAGEM Gilberto Santeiro, Francisco Sérgio Moreira

\section{Sinopse}

Um dos maiores sucessos do documentário brasileiro, reúne imagens de cinejornais, de pequenos produtores, realizadores, independentes, cinematecas e redes de TV, além de entrevistas especiais, para recontar a história política brasileira de 1945 ao fim dos anos 1970. A saga da construção de Brasília é um dos muitos episódios abordados com precisão historiográfica e engajamento emocional, perfazendo um contagiante elogio à democracia.

\section{Disponível em}

DVD para locação.

\section{Informações adicionais}

Grande sucesso de público, "Os anos JK: uma trajetória política" alcançou a impressionante marca de 800 mil espectadores e se tornou um dos documentários brasileiros de maior público de todos os tempos. Dirigido por Silvio Tendler, tem uma narrativa clássica e se vale de entrevistas, fotos, sons e imagens de arquivo para acompanhar a trajetória de Juscelino Kubitschek de Oliveira (1902-1975), desde a sua juventude na pequena Diamantina dos anos 1930, passando pela Presidência da República, entre 1956 e 1961, e chegando aos anos de exílio e à morte em um acidente de automóvel. Mais do que o retrato de um homem visionário, o longa-metragem traça um grande painel da vida política brasileira, suas lutas e seus entraves na busca pelo caminho da democracia, em um país cuja história sempre foi marcada por regimes de exceção.

Referência acessada em junho de 2013: http://www.programadorabrasil.org.br/ programa/106/ 


\section{A idade da terra}

Brasil. Ficção, colorido, 134 minutos

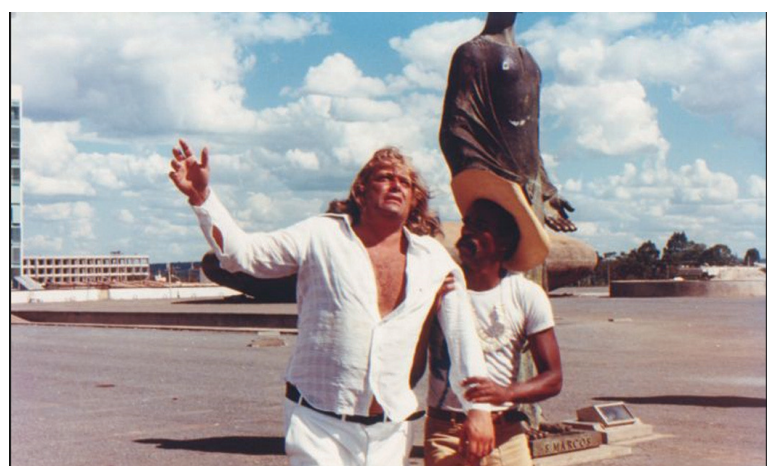

\section{Equipe}

DiREÇÃo, ARGUMENTO E ROTEIRO Glauber Rocha

montagem Carlos Cox, Raul e Ricardo Miranda

fotografia roberto Pires e Pedro de Moraes

COMPANHIA PRoDUtora Glauber Rocha Produções Artísticas Ltda

DIREÇÃo DE PRODUÇÃo Tizuka Yamasaki, Walter Schilke

\section{Sinopse}

Estruturando livremente denúncia política e social, com passagens de caráter abertamente didático ou panfletário, surgem alusões à vida e à missão do Cristo, que aparece ora como operário, ora como personagem de candomblé. Os personagens são metáforas de uma situação política ou arquétipo de um comportamento: um pescador marginal místico, um profeta negro, o conquistador português, o subversivo de classe média, as forças imperialistas, as nações indígenas, a força das amazonas, a mulher moderna e outros. É a própria perplexidade do Terceiro Mundo, numa tentativa de síntese da história econômica ocidental, com apelos à revolução, à compreensão universal, à paz e a uma democracia que não seja nem capitalista nem socialista.(Sinopse a partir do Guia de Filmes)

\section{Disponível em}

DVD para locação

\section{Informações adicionais}

www. cinemateca.gov.br 


\section{O Sonho não Acabou}

Brasil. Ficção, colorido, 99 minutos

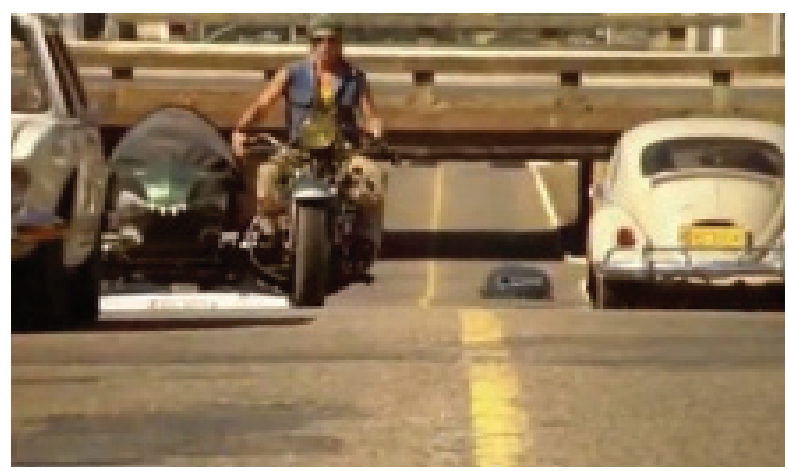

\section{Equipe}

DIRETOR Sergio Rezende

RотеIRo José Joffily, Sérgio Resende e Jorge Duran

PRODUÇÃo EXECUTIVA Marisa Leão

DiREÇÃo DE FOTOGRAFIA Edgar Moura

MONTAGEM Vera Freire

\section{Sinopse}

Após a opressão nos anos 6o, uma nova geração de jovens em Brasília procura escapar do conformismo. Alguns deles experimentam drogas e, eventualmente, fazem parte do tráfico. Numa noite, todos se encontram no mesmo lugar, mas cada um terá um destino diferente. Este filme de Sergio Rezende marcou a estréia de vários atores no cinema brasileiro, dentre os quais Lauro Corona, Miguel Falabella e Lucélia Santos.

\section{Disponível em}

DVD para locação.

\section{Informações adicionais}

Danilo, jovem mecânico, deixa, em sua moto, a cidade-satélite onde mora, com destino ao centro de Brasília. Na mansão de um poderoso burocrata, o pai de Danilo se dedica à construção da piscina, enquanto os respectivos filhos confabulam no quarto. Danilo e um grupo de amigos, vivem intensamente suas aventuras na cidade. Envolvido com traficantes de cocaína, Danilo vende um lote da droga e gasta o dinheiro com uma mulher num luxuoso hotel da cidade. SQI, seu amigo, vende sua parte, gasta o dinheiro em um vôo de monomotor. Nos arredores de Brasília o grupo se reúne em torno de uma fogueira e desabafam as frustrações de sua geração. Sentem-se como uma terra fértil que não foi semeada. Lucinha, sua amiga, grávida, aborta num hospital da cidade. Outra amiga, Carol, atriz de teatro, estréia uma nova peça e homenageia Lucinha. Danilo é surpreendido por uma cilada. Durante a fuga, sofre um acidente, mas consegue escapar. No teatro, o espetáculo se encerra. Carol, João e Ricardo se confraternizam emocionados. Numa beira de estrada, Danilo pede carona.

Informação encontrada no encarte do DVD. 


\section{Brasília, um roteiro de Alberto Cavalcanti}

Brasil. Documentário, colorido, 3 o minutos

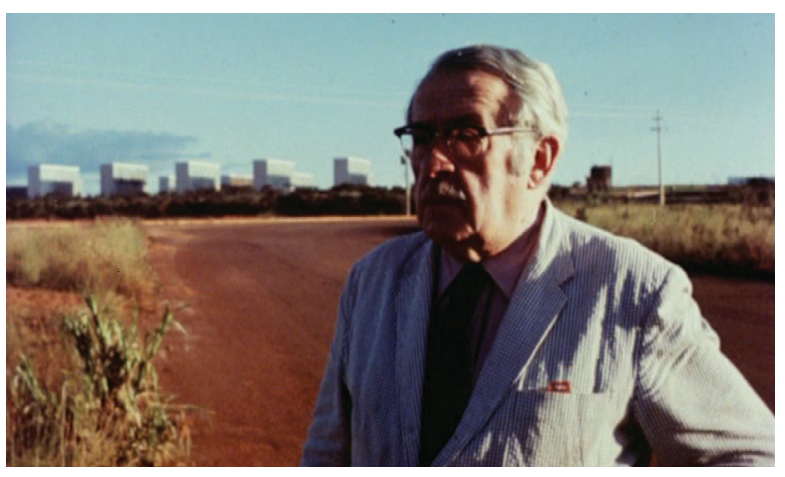

\section{Equipe}

DIRETOR Antonio Carlos Fontoura

ROTEIRo Alberto Cavalcanti

COMPANHIA PRODUTORA Embrafilme

\section{Sinopse}

Uma visão da arquitetura criada por Oscar Niemeyer e Lúcio Costa em Brasília. Uma viagem que começa nas tabas indígenas, passa pela arquitetura colonial e chega à capital brasileira. O filme segue um roteiro deixado por Alberto Cavalcanti, quando a sua passagem por Brasília, em 1978.

\section{Disponível em}

Centro Técnico Audiovisual: CTAV/SAV/MinC

EMAIL comunicacao.ctav@cultura.gov.br, TEL (21) 35017800

\section{Informações adicionais}

Uma leitura poética do espaço urbano e da arquitetura. Primeira exibição pública no Festival de Brasília em 1982.

Referência acessada em junho de 2013: http://cinemateca.gov.br/cgi-bin/wxis.exe/ iah/?IsisScript=iah/iah.xis\&base=FILMOGRAFIA\&lang=P\&nextAction=search\&exprSearch $=\mathrm{ID}=032191 \&$ format $=$ detailed.pft

Trechos transcritos de entrevistas:

"(...) você anda muitos quilômetros e vê todo o espaço que você andou, faz pensar em muita coisa, na vida..."

“(...) não tem muitas tradições e tudo remete a uma maior liberdade individual." 


\section{Mínima Cidade \\ Brasil. Ficção, colorido, 9 minutos}

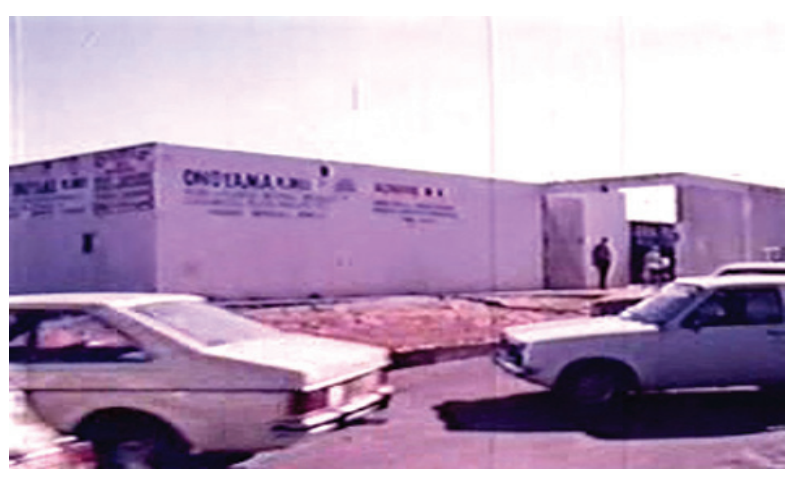

\section{Equipe}

DIREÇÃO E ROTEIRO João Lanari

FOTOGRAFIA Miguel Freire

MONTAGEM Hugo Sérgio Franco

\section{Sinopse}

A busca, a nostalgia do traçado original, narrada por um diálogo imaginário (fragmentário e hesitante) entre Lúcio Costa e Oscar Niemeyer, com o objetivo de trazer à luz a cena original, disfarçada e recalcada nas imagens oficiais. O filme trabalha em cima da pergunta: como transformar um percurso urbano em percurso cinematográfico?

\section{Disponível em}

Com o diretor, copia telecinada em qualidade ruim. 


\section{Brasília, uma Sinfonia}

Brasil. Documentário, colorido, 10 minutos

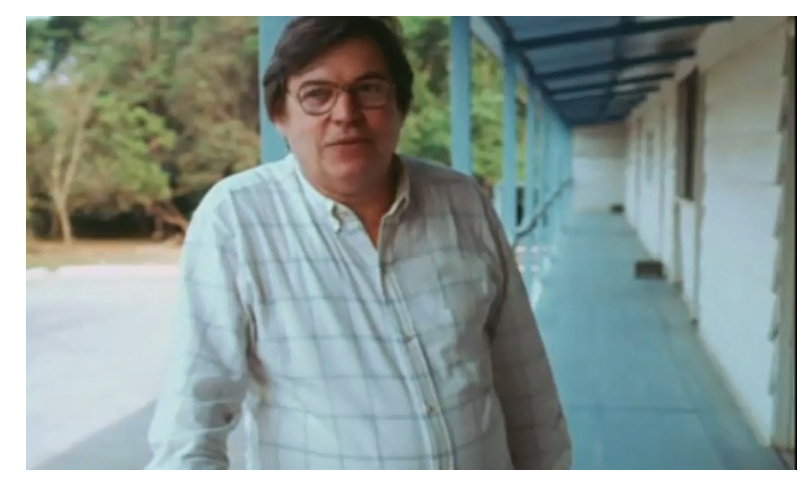

\section{Equipe}

DIRETOR Regina Martinho da Rocha

Roteiro Aluísio Didier

PRODUÇÃo Regina Martinho da Rocha

fotografia Fernando Duarte, Walter Carvalho, César Moraes

montagem Aída Marques, Carlos Cox

\section{Sinopse}

Nas comemorações do 25 aniversário de Brasília, a primeira apresentação da Sinfonia de Brasília, composta por Vinícius de Moraes e Tom Jobim em homenagem à cidade. Com imagens e depoimentos sobre a construção da capital.

\section{Disponível em}

CPCE UnB 


\section{Brasiliários}

\section{Brasil. Ficção, colorido, 11 minutos}

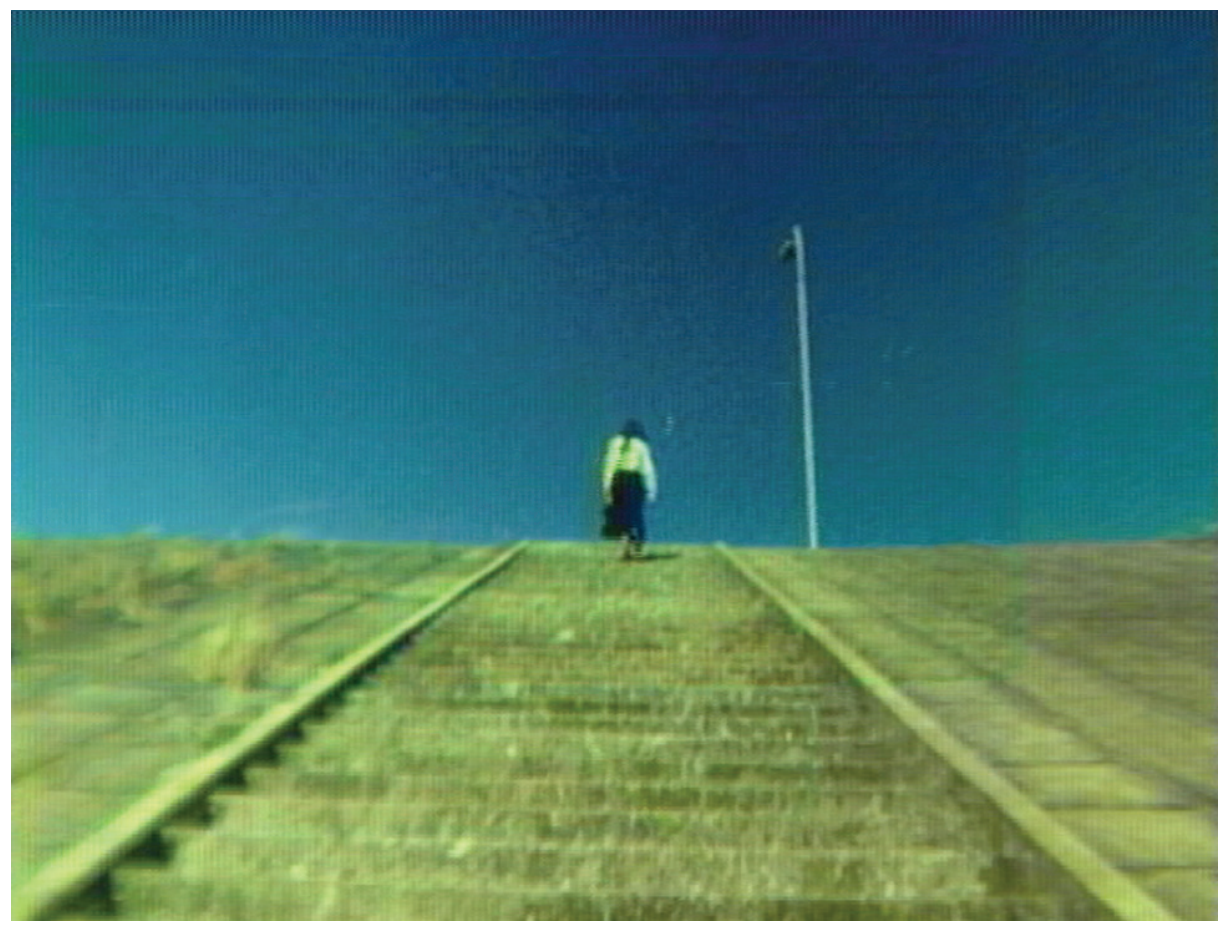

\section{Equipe}

Diretor Sérgio Bazi e Zuleica Porto

roteiro Sérgio Bazi e Zuleica Porto

FOtografia Jacques Cheuiche

MONTAGEM Hugo Franco Mader

\section{Sinopse}

Por meio de narrativa fragmentada e imagens poéticas, o filme mostra o encontro entre uma cidade, Brasília, e uma escritora forasteira, Clarice Lispector. O roteiro é inspirado em dois textos de Clarice, escritos depois de duas temporadas na capital em 1970.

\section{Disponível em}

\section{CPCE/UnB}

\section{Informações adicionais}

O livro "O sonho candango: memória afetiva dos anos 80" , lançado em 2012 pela Gabinete C, de autoria de Alexandre Ribondi, Cláudia Pereira e RomárioSchettino, traz relatos sobre a produção do filme. 


\section{Brasília, a última utopia}

Brasil. Documentário, filme em episódios, colorido, 97 minutos

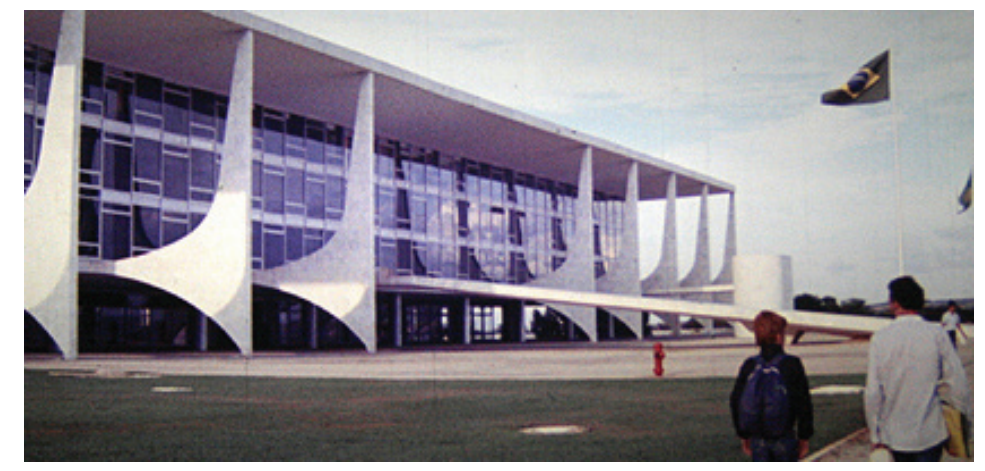

\section{Equipe}

DIREçÃo Pedro Anísio, Geraldo Moraes, Vladimir Carvalho, Pedro Jorge de Castro, Moacir de Oliveira e Roberto Pires

cOMPANHIAS PRODUTORAS Idade Média, Fundação do cinema Brasileiro - Minc Produção José Pereira, Chico dos Santos

\section{Sinopse}

Seis curtas-metragens encomendados a partir da nomeação da capital como Patrimônio Cultural da Humanidade, em 1987. São seis diferentes declarações de amor a Brasília. Tem amor à natureza que a recebeu; tem amor à história que a sustentou e a justificou; tem amor ao misticismo que a mantém misteriosa; tem amor à saudade do tempo da construção da cidade; tem amor à missão como capital do Brasil e tem amor à arte que a inspirou.

\section{Disponível em}

DVD em locadora

\section{Informações adicionais}

O filme foi exibido pela primeira vez no $36^{\circ}$ Festival de Brasília do Cinema Brasileiro, em 1993. Depois caiu no esquecimento. Durante 16 anos uma cópia permaneceu guardada. Com recursos da Terracap, a Secretaria de Cultura do Governo do Distrito Federal recuperou o filme e produziu cópias em DVD.

Episódios:

(1). A Paisagem Natural (de Vladimir Carvalho). Documentário descortina o cerrado, o exuberante sistema natural que hospeda a cidade e que lhe proporciona mais qualidade de vida. (2). O Sinal da Cruz (Pedro Jorge de Castro). Reconta, de forma alegórica, a história do Brasil, abrangendo desde a colonização até a construção de Brasília. (3). A Volta de Chico Candango (Roberto Pires). Um operário que trabalhou na construção de Brasília retorna a cidade e redescobre a capital que ajudou a construir. (4). Além do Cinema do Além (Pedro Anísio). Spirit, personagem de Will Eisner, sai dos quadrinhos para investigar o misticismo de Brasília. (5). Suíte Brasília (Moacir de Oliveira). Um passeio pela arquitetura monumental de Brasília ao som de "Suíte Brasília", música de Renato Vasconcelos que se tornou uma espécie de sinfonia da cidade. (6). A Capital dos Brasis (Geraldo Moraes). Documentário mostra a diversidade de Brasília a partir dos pontos de encontro da cidade, revelando a criação de um sotaque próprio, nascido da mistura dos diversos Brasil.

Referência acessada em: http://cinemateca.gov.br 


\section{Conterrâneos velhos de guerra \\ Brasil. Documentário, preto e branco e colorido, 200 minutos}
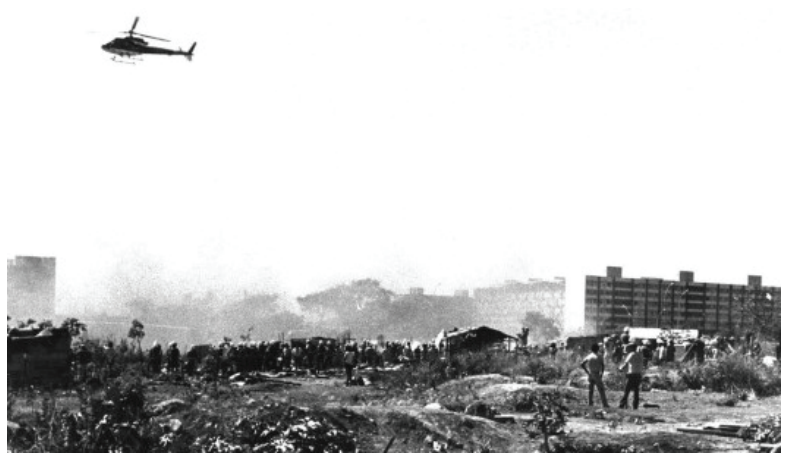

Equipe

DIRETOR Vladimir Carvalho

FinACIADOR Universidade de Brasília, Pólo de Cinema e Vídeo do Distrito Federal PESQUisa, ROTEIRO E AUTORIA DO TEXTO DE LOCUÇÃo Vladimir Carvalho direção de fotografia Alberto; Cavalcanti, David Pennington, Fernando Duarte, Jacques Cheuiche, Marcelo Coutinho, Waldir de Pina, Walter Carvalho.

NARRAÇÃo Othon Bastos

\section{Sinopse}

A história de Brasília desde os tempos pioneiros da construção até os dias atuais, com ênfase na participação das gentes do povo, especialmente nordestinos, que ainda hoje vivem na periferia da cidade.

\section{Disponível em}

DVD pela Programadora Brasil

O DVD foi restaurado e lançado pelo Instituto Moreira Sales em 2014

\section{Informações adicionais}

Os primeiros tempos de Brasília, ainda na construção, em 1959. Os canteiros de obras se espalham por toda parte e os trabalhadores, chamados de candangos, afluem de vários pontos do país, especialmente do Nordeste. As péssimas condições de trabalho, provocaram uma chacina que vitimou grande número de operários. A memória deste e de outros episódios chega aos nossos dias pelo testemunho daqueles que viveram a experiência da construção da capital brasileira.

A saga dos anônimos pedreiros construtores de Brasília que depois da obra concluída e inaugurada a cidade foram rechaçados para a periferia, vivendo hoje em péssimas condições.

Referências acessadas em junho de 2013: http://www.cinemateca.gov.br/cgi-bin/wxis.exe/ iah/

Prêmio Hors Concours; Melhor Filme de Longa-metragem 16mm; de Melhor Diretor; Prêmio da Crítica; Prêmio do Jornal de Brasília pela importância documental e cinematográfica, no Festival de Brasília, 1990. 


\section{Brasília, ano 35}

Brasil. Documentário, colorido, 22 minutos

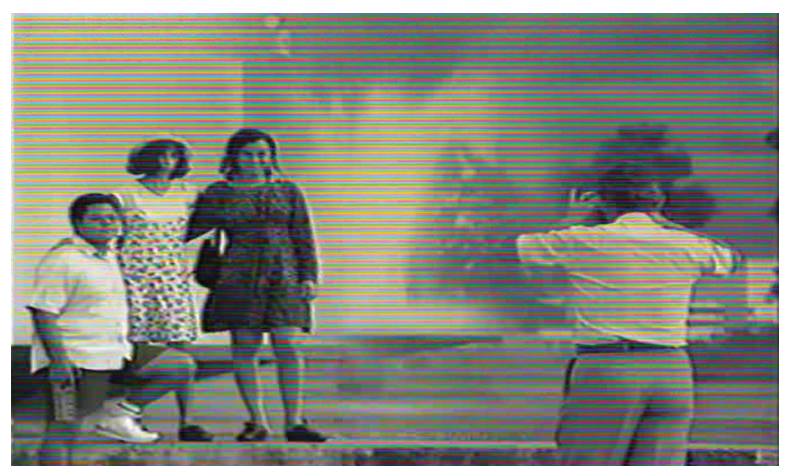

\section{Equipe}

Direção e Fotografia Waldir de Pina

DIREÇÃo GERAL João de Castro

ARGUmento E COORDEnAÇÃo De EDiÇÃo Marcos de Souza Mendes

PRodução Cia de Produção Cinema e Video Ltda

\section{Sinopse}

O filme foi realizado pela Cia do Filme em 1995, primeiro ano do Governo de Cristovam Buarque, seu roteiro de gravação foi construído a partir da Sinfonia da Alvorada, narrado por Vinicius de Morais e Tom Jobim. O filme narra a saga daqueles que cedo chegaram para realizar o seu sonho e o de Dom Bosco também, vindo dos mais distantes lugares do nosso país, construir a nossa capital, Brasília, capital de todos os brasileiros.

\section{Disponível em}

Com o diretor 


\section{Brasília, um dia em fevereiro}

Brasil/Holanda. Ficção, colorido, yo minutos

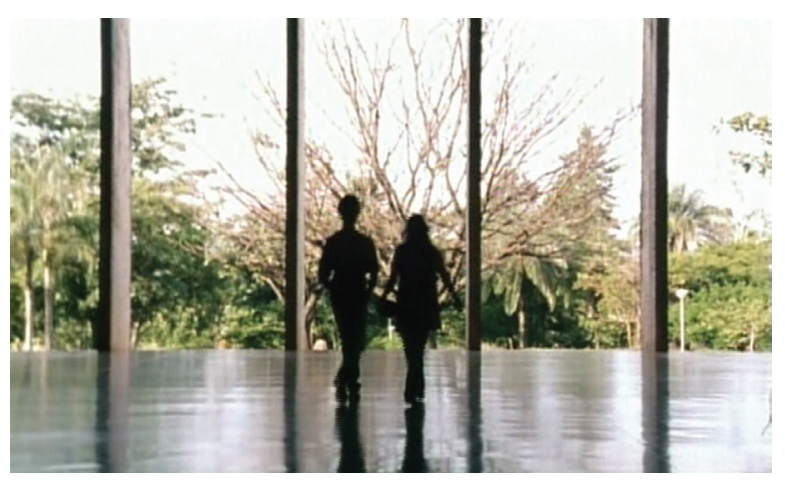

\section{Equipe}

DIRETOR Maria Augusta Ramos

PRODUtor/REALIZAdor Maria AugustaRamos; Maria LuizaTaunay; Iris Hogendijk

DiREÇÃo DE FOTOGRAFIA Mies Rogmans; Joost Van Herwinjnen

MONTAGEM Cecilie Levy

\section{Sinopse}

O cotidiano de três habitantes típicos da capital federal: uma estudante, a mulher de um diplomata, um vendedor ambulante.

\section{Disponível em}

Existe somente uma cópia em DVCAM com a diretora.

\section{Informações adicionais}

Documentário sobre a capital brasileira, a partir das observações de três personagens da cidade, em situações vividas num único dia: uma jovem estudante universitária, a mulher de um diplomata e um vendedor ambulante de espelhos. Usando como tema a vida e os encontros destas pessoas, outros personagens vão entrando em cena. Temas como a propalada solidão dos habitantes de Brasília, o excesso de seus espaços, as distâncias, a falta de praças, os modos de relacionamento e integração engendrados pela própria arquitetura vão sendo discutidos em vários segmentos. A utopia que guiou a própria construção de uma nova capital para o país, no final dos anos 50, é revista 36 anos depois, à luz da realidade.

Documentário sobre a classe média de Brasília.

Referências acessadas em junho de 2013 em: http://www.cinemateca.gov.br/cgi-bin/wxis. exe/iah/ 


\section{Feliz Aniversário Urbana}

Brasil. Ficção, colorido, 14 minutos

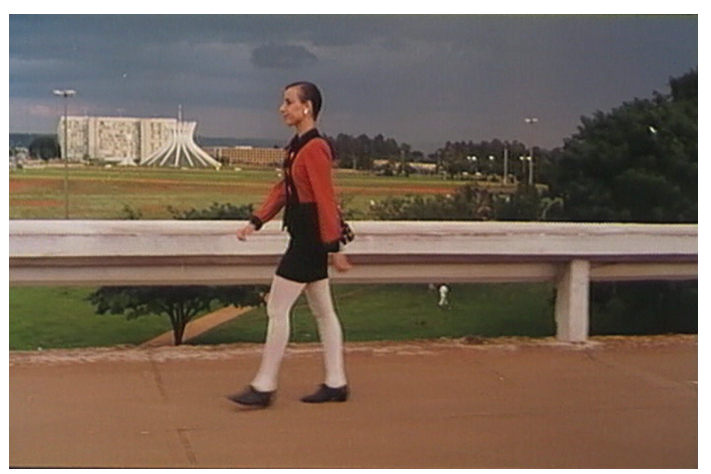

Equipe

DiReÇÃo e RoteIro Betse de Paula

Produtor/REALIZAdor CPCE/UnB, FEMIS - Pólo de Cinema e Vídeo-DF

DIREÇÃo DE FOTOGRAFIA Ricardo Aronovich

MONTAGEM Virginia Flores

\section{Sinopse}

O cotidiano de uma bancária solitária que no dia de seu aniversário só deseja uma coisa: dormir.

\section{Disponível em}

CPCE/UnB e no site http://portacurtas.org.br/filme/?name=feliz_aniversario_urbana

\section{Informações adicionais}

História de 12 horas da vida de uma bancária que no seu aniversário só deseja uma coisa, dormir. Coisa difícil para uma urbana.

MinC/CMB informa ser uma co-produção França / Brasil.

Participou da Mostra Curta Brasília, 1997 no Festival de Brasília.

Referências acessadas em junho de $2014 \mathrm{em}$ : http://cinemateca.gov.br/cgi-bin/wxis.exe/ $\mathrm{iah} /$ ?IsisScript=iah/iah.xis\&base=FILMOGRAFIA\&lang=P\&nextAction=search\&exprSearch $=\mathrm{ID}=021445 \&$ format $=$ detailed.pft 


\section{Dois Candangos: a história passou por aqui}

Brasil. Documentário, colorido, 32 minutos

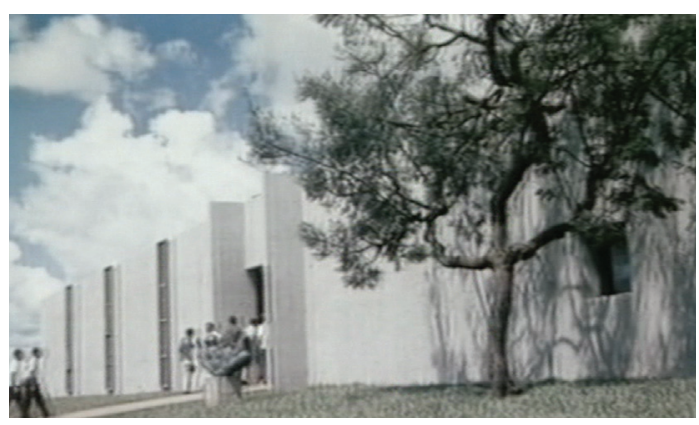

Equipe

DIRETOR Armando Bulcão e Tania Montoro PRODUTOR/REALIZADOR DAC/DEA/DAP/CPCE UnB

PESQUisA E ENTREVISTAS Alunos da disciplina Produção, Redação e Edição de TV, 1994 EDIÇÃo Armando Bulcão

\section{Sinopse}

Dois Candangos é um registro histórico que resgata a memória social de um espaço cultural, homenageando a pessoa do arquiteto Alcides Rocha Miranda, responsável pelo conjunto arquitetônico onde se encontra o auditório. Dedicado aos operários mortos durante sua construção.

\section{Disponível em \\ CPCE/UnB}

\section{Informações adicionais}

O Documentário Dois Candangos foi realizado em 1994 e dele participaram alunos, professores e funcionários da UnB, assim como personalidades ligadas às artes e à cultura do DF. A pesquisa iconográfica com imagens de fotos e filmes inéditos, além dos depoimentos, relembram passagens singulares de Brasília e da UnB, como a aula inaugural, as invasões militares do Campus Universitário, a conturbada visita do ex-secretário norteamericano Henry Kissinger e os debates sobre cinema.

Informações da própria diretora Tania Montoro, fornecidas para a mostra "UnB 50 anos Luz, câmera, Brasília", em 2012. 


\section{Barra 68, sem perder a ternura}

Brasil. Documentário, preto e branco e colorido, 8 o minutos

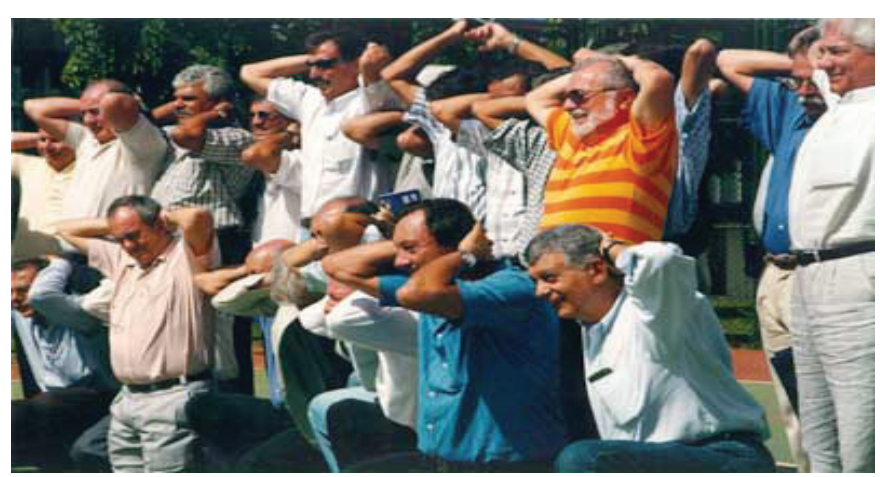

\section{Equipe}

PESQUISA, ROTEIRO E DIREÇÃo Vladimir Carvalho

PRODUÇÃo Folkino Produções Audiovisuais

FOTOGRAFia E CÂMERA André Luis da Cunha

EDIÇÃo E MONTAGEM Manfredo Caldas e Vladimir Carvalho

\section{Sinopse}

A luta de Darcy Ribeiro no início dos anos 60 para criar e implementar a Universidade Brasília. E as repetidas agressões sofridas pela UnB, desde o golpe militar de 64 até os acontecimentos de 1968, quando foram detidos numa quadra de esportes no campus, cerca de 500 estudantes. A crise culmina com o Ato lnstitucional $n^{\circ} 5$, o AI-5, que fechou o Congresso Nacional. Desde os seus primórdios, Brasília foi fortemente marcada pelos acontecimentos políticos, como a renúncia de Jânio Quadros e o golpe militar de 64. Essa trajetória é resgatada através da urdidura de depoimentos, casos e histórias mesclados às raras imagens e sons que ficaram e perfazem, de uma época, uma memória imperfeita, mas sempre verdadeira.

\section{Disponível em}

Uma edição restaurada foi lançada pela Editora da Universidade de Brasília, em 2013. 


\section{Subterrâneos}

Brasil. Ficção, colorido, 86 minutos

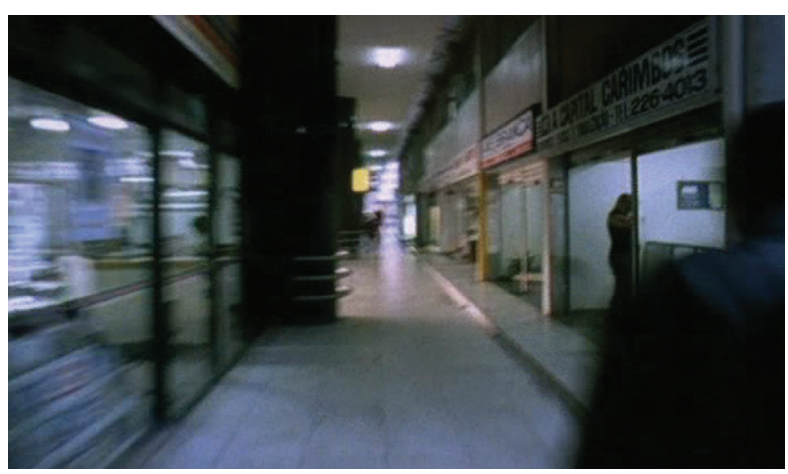

Equipe

DIRETOR José Eduardo Belmonte

ROTEIRo Breno Alex

PRoduÇão executiva José Eduardo Belmonte, André Luis da Cunha, Cibele Amaral FOTOGRAFia André Lavenéré e André Luís Da Cunha

\section{Sinopse}

Breno, sindicalista que abandona o trabalho para escrever um livro sobre o Conic - centro comercial de Brasília povoado por prostituas, evangélicos e travestis. Durante três dias, Breno percorre os corredores do local, onde encontra figuras como Ângela, que busca desesperadamente uma solução para sua vida e Giovani, um italiano que está gravando um documentário sobre o Conic.

\section{Disponível em}

Com o diretor 


\section{A Concepção}

Brasil. Fiç̧ão, colorido, 96 minutos

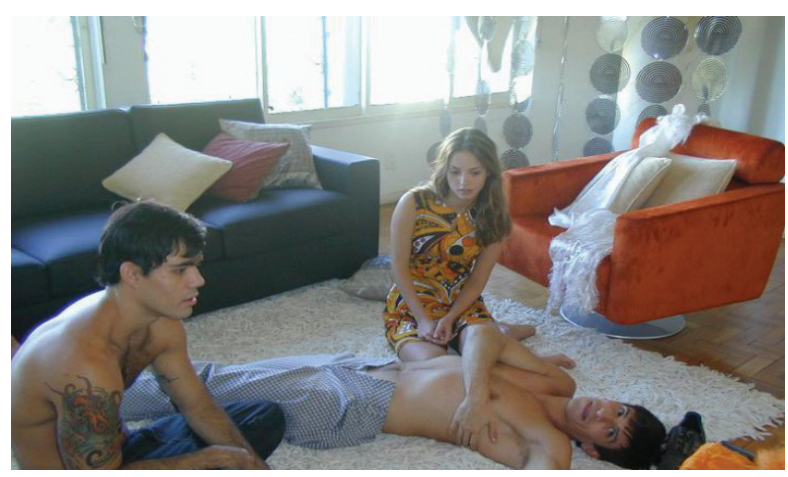

Equipe

DIRETOR José Eduardo Belmonte

ARGumento Breno Álex, Luís Carlos Pacca

PRoDUÇão Paulo Sacramento, Lili Bandeira

FOTOGRAFIA André Luís da Cunha

\section{Sinopse}

Alex (Juliano Cazarré), Lino (Milhem Cortaz) e Liz (Rosanne Holland) são filhos de diplomatas que vivem juntos em Brasília num apartamento vazio, sem os pais, e cheio de quinquilharias. Trocam afetos variados alheios ao mundo. Entediados, tentam viver cada dia como se fosse único. O processo radicaliza quando X (Matheus Nachtergaele), uma pessoa sem nome e sem passado, entra na casa e propõe ir sem freios na idéia de viver apenas um dia.

\section{Disponível em}

DVD para locação

\section{Informações adicionais}

O filme apresenta um grupo de jovens brasilienses dispostos a destruir o conceito de identidade para se reinventar a cada dia. Essa é a regra principal do Manifesto Concepcionista: 1. Morte ao ego. 2. Ser uma nova personalidade a cada dia. 3. Toda memória deve ser apagada. 4. O dinheiro deve ser abolido. 5. A humanidade está doente, o concepcionismo é o caminho para a cura. 6 . O concepcionista é uma fraude que dura 24 horas. 7. O caminho do excesso leva ao palácio da sabedoria). 


\section{Oficina Perdiz}

Brasil. Documentário, colorido, 20 minutos

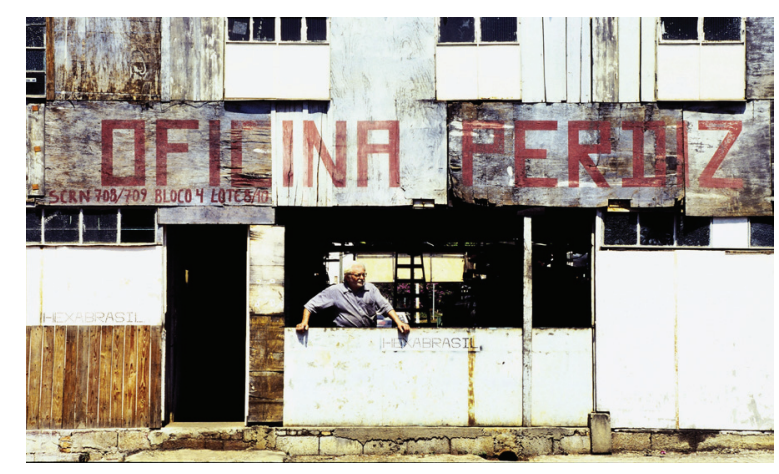

\section{Equipe}

DIRETOR Marcelo Diaz

ROTEIRo Marcelo Diaz

PRODUÇÃo Marcelo Diaz

DIREÇÃO DE PRODUÇÃo José Geraldo

FOTOGRAFIA Krishna Schmidt

MONTAGEM Edu Jung

\section{Sinopse}

Perdiz instalou sua oficina mecânica em uma área pública na cidade planejada de Brasília (Brasil), no ano de 1969. Há 17 anos abriu seu espaço pela primeira vez para o teatro com Esperando Godot de Becket. E não parou mais. Hoje permanece no mesmo local, dividido entre peças mecânicas e teatrais. Entretanto, continua irregular.

\section{Disponível em}

DIAZUL DE CINEMA: www.diazul.com.br

http://portacurtas.org.br/filme/?name=oficina_perdiz 


\section{Kiss Kiss Kissinger}

\section{Brasil. Documentário, colorido, 18 minutos}

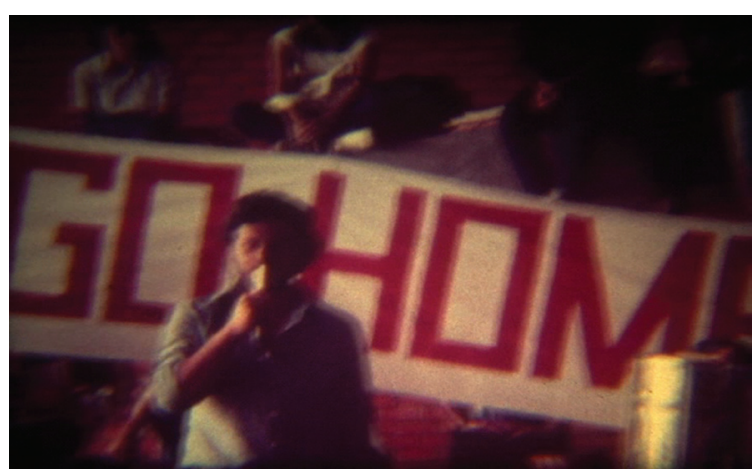

\section{Equipe}

DIREÇÃo E ROTEIRO Jimi Figueiredo

PRODUÇÃo Claudio Moraes, Jimi Figueiredo, Ricardo Movits

FOTOGRAFia Claudio Moraes, Jimi Figueiredo

MONTAGEM Jimi Figueiredo

\section{Sinopse}

Retoma trechos de filmes em super 8 com filmagens feitas em 1981, pelo próprio diretor, na ocasião da visita do diplomata americano Henry Kissinger à Universidade de Brasília. A visita de Kissinger, financiada pelo governo ainda militar, causou revolta nos estudantes, levando a uma manifestação de grandes proporções no campus da UnB.

\section{Disponível em}

Com o diretor 


\section{Romance do Vaqueiro Voador}

Brasil. Documentário/ficção, colorido, 71 minutos

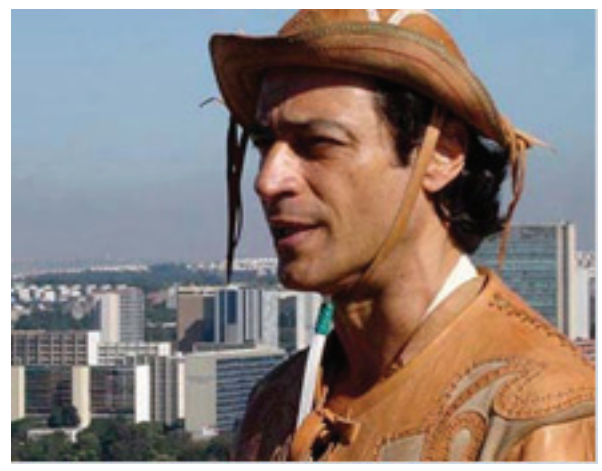

\section{Equipe}

DIRETOR Manfredo Caldas

ROTEIRo Manfredo Caldas e Sérgio Moriconi

PRODUTOR EXECUTIVo Márcio Curi

CO-PRODUÇão Folkino Produções audiovisuais

Fotografia Waldir de Pina

\section{Sinopse}

Romance do Vaqueiro Voador é um documentário poético de longa metragem, idealizado e dirigido pelo documentarista Manfredo Caldas, baseado no poema homônimo de João Bosco Bezerra Bonfim. Trata sobre a recriação do universo mítico do nordestino, ao vivenciar a nova diáspora, no papel de candango, protagonizando o lado trágico da epopéia da construção da nova capital do Brasil.

\section{Disponível em}

Com o próprio diretor

\section{Informações adicionais}

No princípio era a imagem cinematográfica do sertão e da cidade em construção, e veio João, o poeta-escritor, e transformou-a em livro. E deu-se depois que tomando o texto nas mãos, Manfredo, o poeta-cineasta, fez com que voltasse a ser cinema. Foi o milagre dialético da criação desse bem aventurado Romance do Vaqueiro Voador." (Vladimir Carvalho)

Manfredo Caldas pertence à segunda leva de cineastas que se seguiu ao movimento do cinema paraibano surgido no início dos anos sessenta com o documentário "Aruanda", de Linduarte Noronha, consagrado nacional e internacionalmente. Em Brasília desde 1995, assume a Direção do Pólo de Cinema e Vídeo até o início de 1997, criando então a empresa FolKino Produções Audiovisuais. Entre 1999 e 2000, juntamente com Vladimir Carvalho, produz o documentário de longa-metragem "Barra 68, sem perder a ternura", tendo também assumido a montagem e edição de som.

Referência acessada em junho de 2013 em: http://nelianelinda.webnode.com/cultura/ 


\section{Memórias finais da República de Fardas}

Brasil. Documentário, colorido, 38 minutos

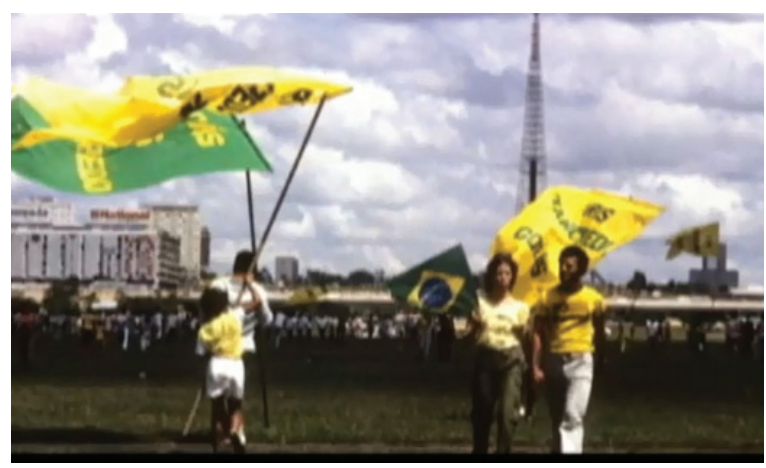

Equipe

DIRETOR Gabriel F. Marinho

ROTEIRO Gabriel F. Marinho

PRODUÇÅO EXECUTIVA Totó Filmes e Villa-Lobos Produções

FOTografia Andressa Anholete, Emília Silberstein e André Gomes

MonTAGEM/EDição Gabriel Catta Preta

\section{Sinopse}

Quase 25 anos depois da maior campanha cívica que o Brasil já presenciou, os habitantes do Distrito Federal contam suas versões e percepções do movimento que lutava por eleições diretas para Presidente do Brasil. Aqui, homens e mulheres, a maioria desconhecidos, contam as histórias de quem não subiu nos palcos dos grandes showmícios.

\section{Disponível em}

Com a empresa produtora: Villa Lobos Produções.

DVD Programadora Brasil: http://www.programadorabrasil.org.br/filme/1451/ 


\section{A saga das candangas invisíveis}

2008 Brasil. Documentário, colorido, 15 minutos

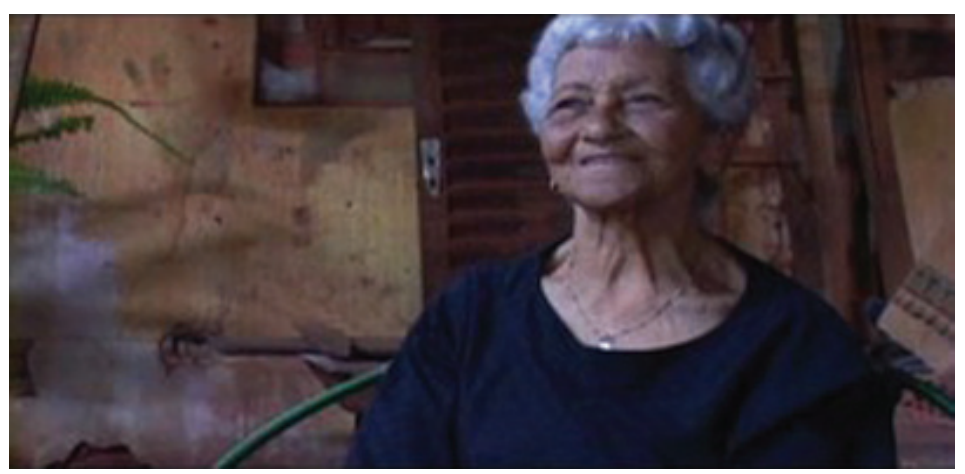

\section{Equipe}

DIREÇÃo Denise Caputo

roteiro Denise Caputo e Ricardo Lucas

PRoduÇão Adriana Mota, Denise Caputo

Fotografia Cícero Bezerra

\section{Sinopse}

A trajetória de um segmento de mulheres à margem da história oficial: as prostitutas que chegaram a Brasília ainda na época da construção da cidade, no final dos anos 50, guiadas pelo sonho de um Brasil novo. Expectativas, dificuldades, frustrações e a vida cotidiana das primeiras meretrizes da capital do País.

\section{Disponível em}

Com a produtora, e para download no site http://www.youtube.com/watch?v=DTy3 $6{ }_{9} \mathrm{E}_{3} \mathrm{Pg}$ 


\section{Dias de greve}

Brasil. Ficção, colorido, 25 minutos

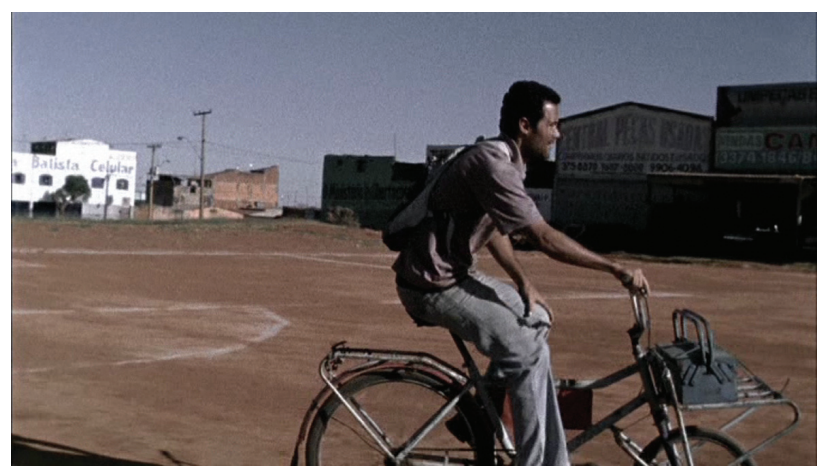

\section{Equipe}

DIRETOR Adirley Queirós

ROteiro Adirley Queirós

PRoDuçÃo executiva Adirley Queirós, Simone Gonçalves e Thiago Mendonça

FOTOGRAFIA André Carvalheira

MONTAGEM Marcius Barbieri

\section{Sinopse}

Uma greve de serralheiros é deflagrada em uma periferia da capital federal. Neste período, muito mais que um despertar para uma consciência de classe, os operários redescobrem uma cidade e um tempo que não mais lhes pertencem.

\section{Disponível em}

Com o próprio diretor 


\section{Insolação}

Brasil. Ficção, colorido, 93 minutos

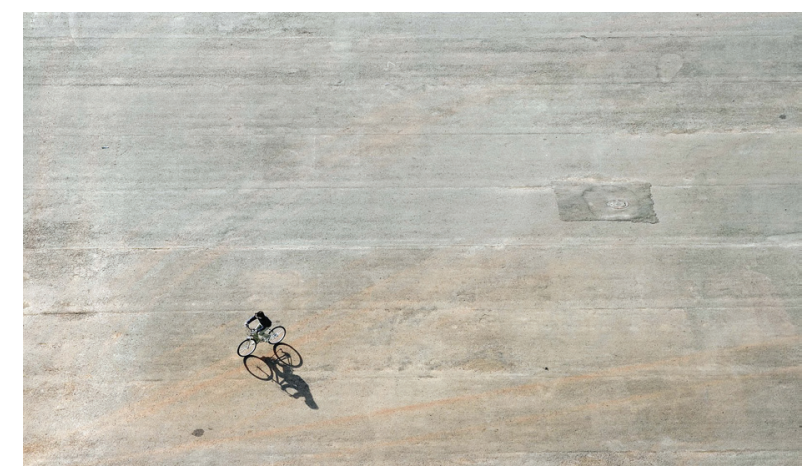

\section{Equipe}

DIRETOR Felipe Hirsch, Daniela Thomas

Roteiro Will Eno, Sam Lipsyte

PRODUÇÃo Sara Silveira, Beto Amaral, Pedro Igor Alcântara, Maria Ionescu.

fotografia Mauro Pinheiro Jr

\section{Sinopse}

Numa cidade vazia, castigada pelo sol, jovens e velhos confundem a sensação febril da insolação com o início delicado da paixão. Como espectros, eles vagam entre construções e descampados em busca do amor inalcançável.

\section{Disponível em}

DVD para locação

\section{Informações adicionais}

"Insolação" é uma arriscada narrativa sobre um tema tão trivial quanto insondável: o amor inalcançável e a melancolia que ele engendra. Para falar dessa utopia frustrada, a dupla de diretores escolheu Brasília como cenário: ela também é uma utopia irrealizada, tanto na política como no urbanismo. Mas o que vemos na tela não é a Brasília de cartãopostal com a catedral, a esplanada dos ministérios e outros edifícios conhecidos. O filme mostra uma Brasília fragmentada, meio em ruínas, que jamais é nomeada. Apenas a monumentalidade fria dos edifícios e dos grandes espaços abertos é preservada, trabalhada pelos enquadramentos rigorosos, cujo refinamento destila uma poesia grave. Nessa cidade estilizada não há viva alma além dos poucos personagens.

Referência acessada em junho de 2013 em: http://wwwı.folha.uol.com.br/fsp/ilustrad/ fq2603201013.htm 


\section{Braxília}

Brasil. Documentário, colorido, 17 minutos

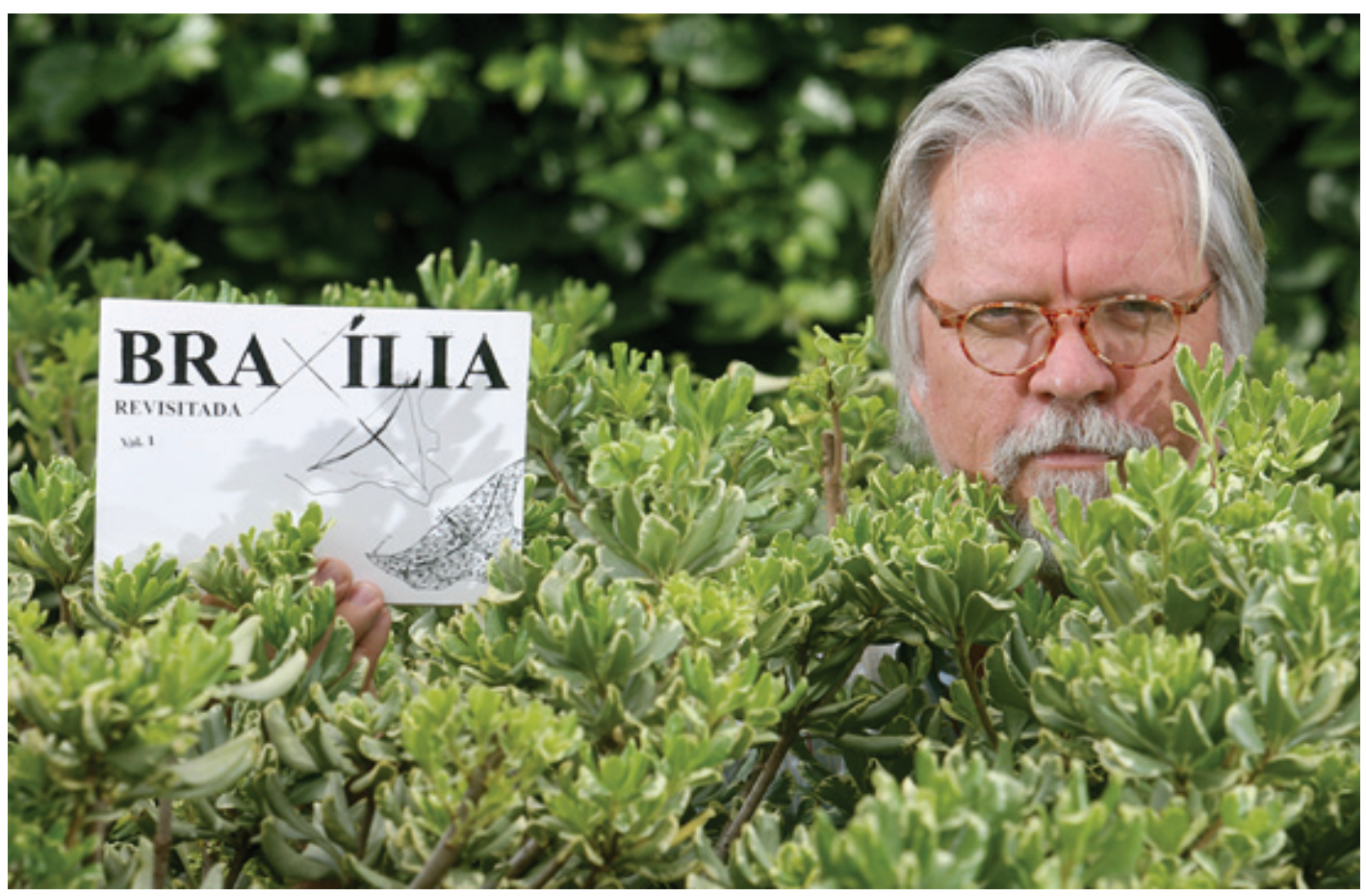

Equipe

DiRetor Danyella Proença

ROTEIRo Danyella Proença

PRODUÇÃo EXECUTIVA Andréa Glória

DIREÇÃo DE FOTOGRAFIA André Macedo

MONTAGEM Marcius Barbieri

\section{Sinopse}

Braxília é um documentário cujo foco é o olhar do poeta Nicolas Behr sobre Brasília.

Buscando uma linguagem lúdica e poética, o filme pauta-se em três eixos fundamentais: entrevistas com Behr; poemas narrados pelo poeta; e intervenções no cenário urbano, com poemas grafados em diferentes suportes arquitetônicos.

\section{Disponível em}

cor@corfilmes.com.br

www.corfilmes.com.br 


\section{A arte de andar pelas ruas de Brasília \\ Brasil. Ficção, colorido, 17 minutos}

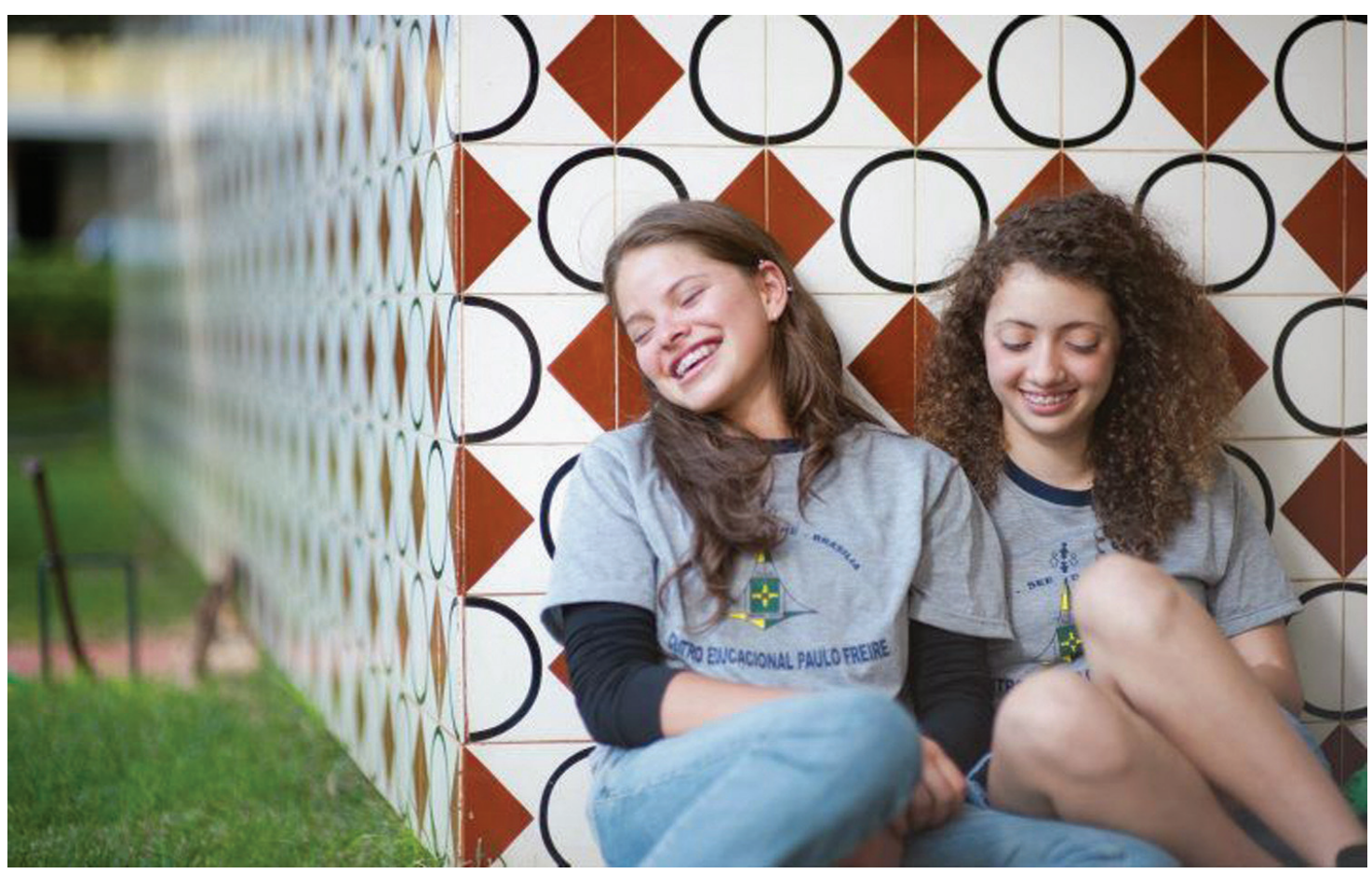

Equipe

DiRETOR Rafaela Camelo

ROTEIRo Rafaela Camelo

PRODUÇão Daniela Marinho, Érico Cazarré (Caza Filmes)

FOTOGRAFIA Leonardo Feliciano

montagem Edu Jung, Rafaela Camelo

Sinopse

Duas garotas se encontram na cidade.

Disponível em

Com a diretora e em http://portacurtas.org.br/filme/?name=a_arte_de_andar_pelas_ruas_ de_brasilia 


\section{Sob o signo da poesia}

Brasil. Documentário, colorido, 65 minutos

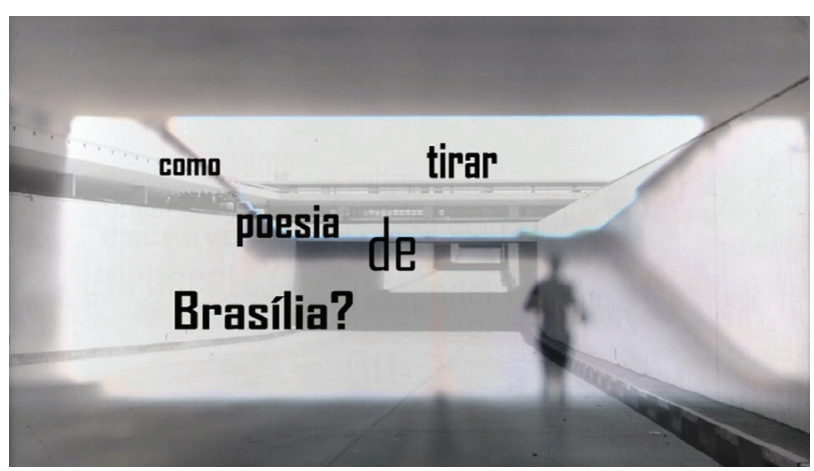

\section{Equipe}

DIRETOR Neto Borges

ROTEIRO Neto Borges

PRODUÇão Olho Filmes

FOTOGRAFIA Neto Borges

\section{Sinopse}

Se cidades tivessem signos, o de Brasília seria a Poesia, seu ascendente seria a diversidade e sua lua seria povoada por poetas. O filme documentário Sob o signo da Poesia traz versos declamados em feixes de luz dando forma à história lírica da cidade desde quando nossos ancestrais indígenas habitavam essas terras de árvores retorcidas.

\section{Disponível em}

\section{Com o diretor}

\section{Informações adicionais}

Além da rica fotografia, o longa-metragem do diretor Neto Borges rima música à chuva e à seca do Cerrado e as cores do céu tiram os sentidos para dançar.

E cinquenta anos depois, ainda é proibido pisar na grama?

Sob o Signo da Poesia é uma das mais abrangentes tentativas de se mapear os caminhos das artes na capital federal. Personagens da história cultural da cidade, como Nicolas Behr, Bené Fonteles, Ivan Presença, Maria Maia e Renato Matos emprestam sua obra e suas vozes para a reconstrução dos caminhos poéticos e afetivos de Brasília. O filme traz versos declamados em feixes de luz dando forma à história lírica da cidade desde quando os ancestrais indígenas habitavam as terras do cerrado.

Informações retiradas da capa do DVD. 


\section{Rock Brasília}

Brasil. Documentário, colorido, 111 minutos

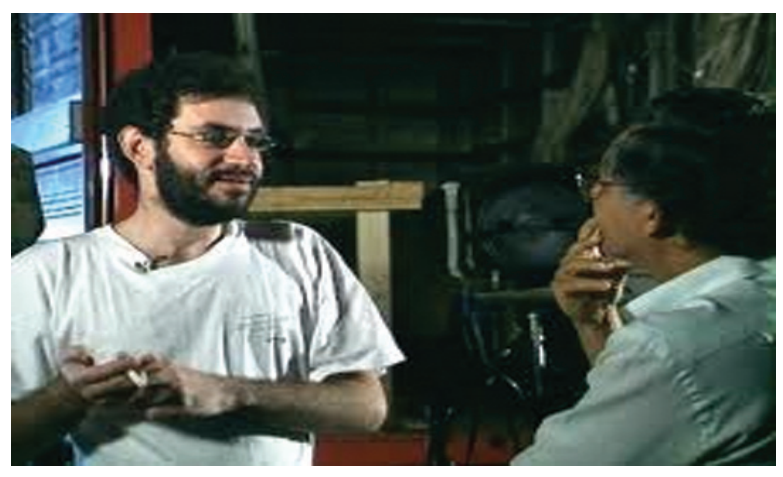

Equipe

DIREÇÃo E RoteIro Vladimir Carvalho

PRODUÇÃO Marcus Ligocki

Fotografia André Carvalheira

MONTAGEM Vladimir Carvalho e Sérgio Azevedo

\section{Sinopse}

Com imagens de arquivo, filmadas por Vladimir Carvalho desde o final dos anos 1980, o documentário encerra uma trilogia sobre a construção cultural e ideológica da Capital Federal. Traz as bandas de Brasília - Legião Urbana, Capital Inicial, Plebe Rude - que fizeram a trajetória clássica do herói: vencer empecilhos e ir atrás de um grande desafio que era a conquista de um lugar na cultura nacional. Eles fazem parte da primeira geração de filhos de intelectuais, diplomatas e políticos que começou a surgir nos anos 1980.

\section{Disponível em}

DVD a venda em lojas e disponível em locadoras

\section{Informações adicionais}

Um filme que fala sobre a relação de pais e filhos que vieram para Brasília. 


\section{Cru}

Brasil. Ficção, colorido, 73 minutos

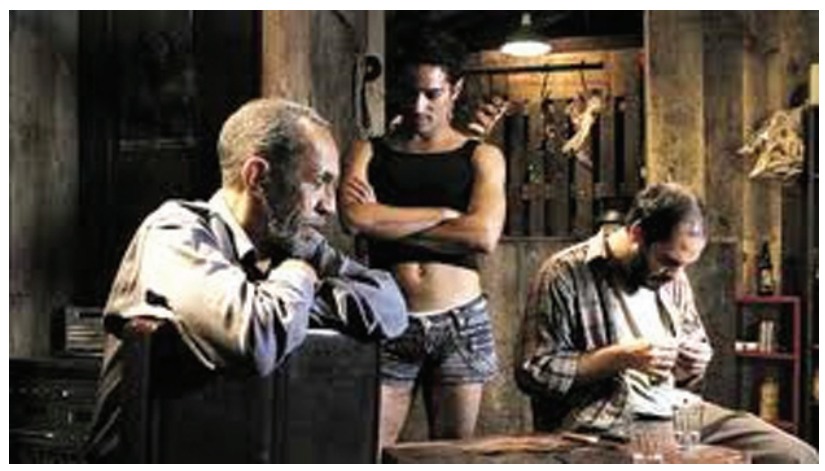

Equipe

DIREÇÃo E ROTEIRO Jimi Figueiredo

ARGUMENTO E ROteIRo Alexandre Ribondi

PRODUÇÃo Claudio Moraes

FOTOGRAFIA Alexandre Magno

\section{Sinopse}

Num açougue perdido no interior do Brasil, um forasteiro contrata os serviços de um matador de aluguel. $\mathrm{O}$ que parece ser um crime encomendado, então, torna-se um inevitável acerto de contas entre os personagens e seus passados.

\section{Disponível em}

www.cinemacinema@globo.com

\section{Informações adicionais}

Para mais informações ver: http://filmecru.blogspot.com.br/2011/03/cru.html 


\section{A cidade é uma só?}

Brasil. Documentário/ficção, colorido, 73 minutos

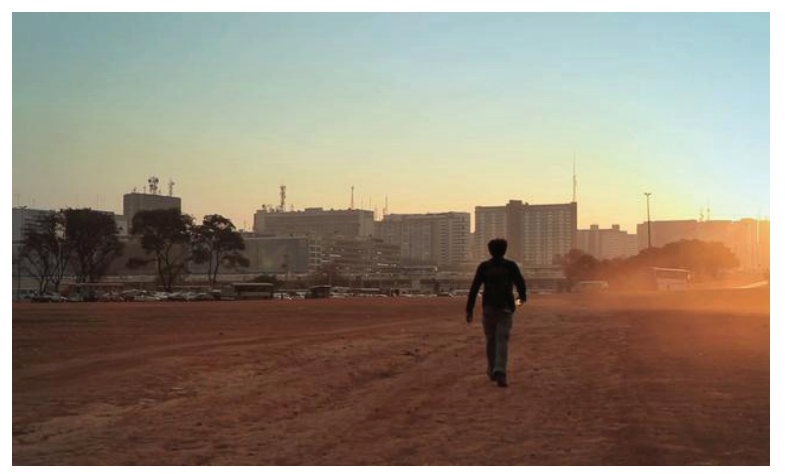

\section{Equipe}

DIREÇÃo e RoteIRo Adirley Queirós

PRODUÇÃo Adirley Queirós, André Carvalheira

DIREÇÃo DE FOTOGRAFIA Leonardo Feliciano

MONTAGEM Marcius Barbieri

\section{Sinopse}

Reflexão sobre os $5^{0}$ anos de Brasília, tendo como foco a discussão sobre o processo permanente de exclusão territorial e social que uma parcela considerável da população do Distrito Federal e do Entorno sofre, e de como essas pessoas restabelecem a ordem social através do cotidiano. $O$ ponto de partida dessa reflexão é a chamada Campanha de Erradicação de Invasões (CEI), que, em 1971, removeu os barracos que ocupavam os arredores da então jovem Brasília. Tendo a CEILÂNDIA como referência histórica, os personagens do filme vivem e presenciam as mudanças da cidade.

\section{Disponível em}

Com o produtor

\section{Informações adicionais}

Palavras do Diretor:

"Meus pais foram expulsos da cidade de Brasília, sou da primeira geração pós-aborto territorial. Moro em CEILÂNDIA, periferia de Brasília, há mais de 30 anos. Eu me tornei cineasta e grande parte do meu trabalho está relacionado com este tema. Tudo aquilo que sou, que penso, tudo aquilo que minha geração é, como ela age, é fruto desta contradição de ser e não ser de Brasília. É fruto do acúmulo da experiência de 50 anos desta cidade-capitalBrasília. Essa experiência nos faz refletir sobre a cidade. Ao contrário do tom afirmativo do jingle oficial que embalava a criação de Ceilândia (A cidade é uma só!), inevitavelmente temos que respirar, dar um passo atrás e nos questionar: a cidade é uma só?"

Referência acessada em junho de 2013 em: http://www.40ofilmes.com/longas/a-cidade-euma-so/ 


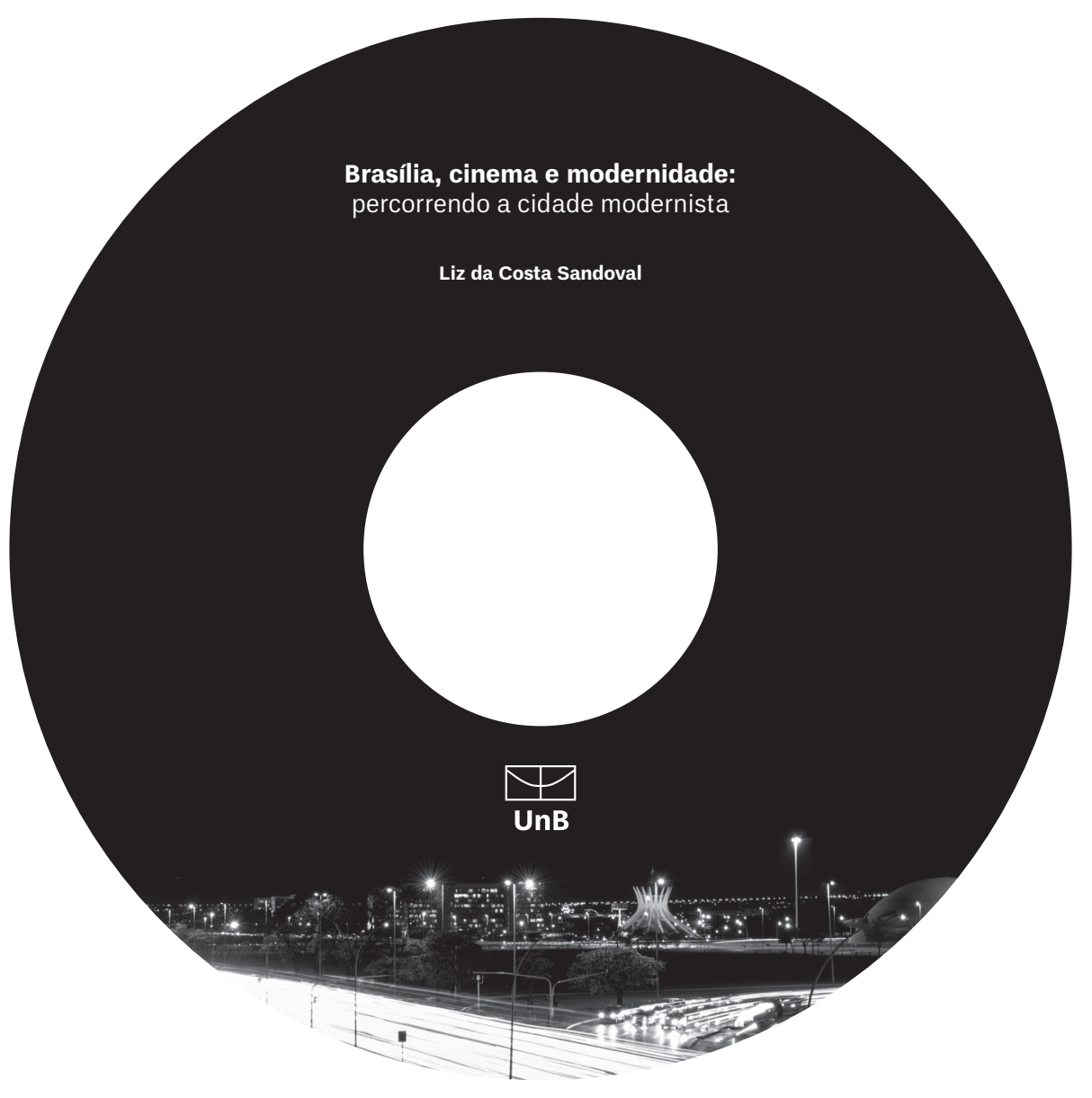

